ALINE MARIA DIAS BASTOS

\title{
REGIME DISCIPLINAR DO SERVIDOR PÚBLICO TEMPORÁRIO
}

\author{
Tese de Doutorado
}

Orientadores: Professor Associado Dr. Edmir Netto de Araújo e Professora Catedrática Dr. ${ }^{a}$ Maria João Estorninho

UNIVERSIDADE DE SÃO PAULO

FACULDADE DE DIREITO

UNIVERSIDADE DE LISBOA

FACULDADE DE DIREITO

São Paulo-SP

2014 
Tese apresentada à Banca Examinadora do Programa de Pós-Graduação em Direito, da Faculdade de Direito da Universidade de São Paulo, como exigência parcial para a obtenção do título de Doutor em Direito, na área de concentração Direito do Estado, sob a orientação do Professor Associado Dr. Edmir Netto de Araújo e da Professora Catedrática Dr. ${ }^{\text {a }}$ Maria João Estorninho, da Faculdade de Direito da Universidade de Lisboa.

UNIVERSIDADE DE SÃO PAULO

FACULDADE DE DIREITO

UNIVERSIDADE DE LISBOA

FACULDADE DE DIREITO

São Paulo-SP

2014 
ALINE MARIA DIAS BASTOS

REGIME DISCIPLINAR DO SERVIDOR PÚBLICO TEMPORÁRIO

BANCA EXAMINADORA 
Com muito carinho, dedico este trabalho ao meu querido, amado e inesquecível pai, José Maria Martins Dias. 


\section{AGRADECIMENTOS}

A Deus, por ter iluminado meu caminho de lutas e por ter-me dado força espiritual nos momentos mais difíceis.

Ao meu marido Mauro, por sua compreensão e seu companheirismo.

Às minhas filhas amadas Alícia e Fernanda, pelo carinho e pelas alegrias que todos os dias recebo.

À minha querida mãe Alice, ao meu irmão José Maria Júnior, à Dina e amigos, pelo constante incentivo e apoio moral.

Aos Professores Doutores Edmir Netto de Araújo e Maria João Estorninho, pela orientação precisa, pela confiança e pela seriedade acadêmica.

À Doutora Sandra Akemi Shimada Kishi, pelas valiosas lições, pela solicitude e pelo estímulo.

Aos amigos Ana Maria Pedreira, Ana Maria Rodrigues Barata, Ethel Martinez de Azevedo Camargo, José Roberto Pimenta Oliveira, Lucivaldo Vasconcelos Barros, Maria da Graça Ferreira Leal, Maristela Simon Szpeiter Lopes de Oliveira, Mônica Martins Toscano Simões, Raquel Ferreira Carlos, Ruth Helena Pimentel de Oliveira, Zélia Luiza Pierdoná, pela atenção e pelas sensatas observações.

À Maria de Fátima Silva Cortinhal e à Cátia Miguens, pelo apoio administrativo da Universidade de São Paulo e da Universidade de Lisboa.

À Procuradoria da República no Estado do Pará e à Procuradoria Regional da República da Terceira Região, pela oportunidade de realização da pós-graduação em São Paulo. 
"Por grande e digno que seja o ideal a que se aspira, só terá valor quando conseguido, se 0 foi de maneira honesta".

VAN DONGEN 
BASTOS, Aline Maria Dias. Regime disciplinar do servidor público temporário. 2014. 266 f. Doutorado - Faculdade de Direito, Universidade de São Paulo, São Paulo, 2014.

\section{RESUMO}

O presente trabalho tem por objetivo aprofundar o regime jurídico disciplinar do servidor público temporário. Analisam-se as características principais dessa espécie de agente público que o diferenciam dos demais servidores e que justificam um regime disciplinar próprio. Em uma breve investigação sobre as prováveis origens do temporário, constata-se a presença desse servidor na Administração Pública brasileira desde 1823. No direito estrangeiro (particularmente, no direito francês e no direito português), verifica-se a existência de figuras assemelhadas ao servidor público temporário brasileiro, que é uma espécie de "servidor público" do gênero "agente público", exercendo uma função pública, mas não ocupando nem cargo, nem emprego públicos, sendo contratado por tempo determinado para atender a necessidade temporária de excepcional interesse público. A Constituição Federal, em seu artigo 37, IX, indica que a lei estabelecerá os casos de contratação por tempo determinado, mas não há uma uniformidade entre os entes da federação sobre o regime jurídico adotado para o servidor temporário. Esta análise concentra-se na Lei Federal n. ${ }^{\circ}$ 8.745/93, que disciplina o assunto. No âmbito federal, o servidor público temporário é dotado de um regime jurídico com características mais próximas do regime jurídico administrativo, sendo recrutado por meio de contrato administrativo assemelhado ao regime estatutário. Tal contratação deve pautar-se pela observância dos princípios da continuidade do serviço público, da moralidade, da impessoalidade, da razoabilidade, da proporcionalidade e da motivação. Focaliza-se a responsabilidade do servidor público temporário no âmbito administrativo, procurando-se demonstrar que tal servidor, por um princípio de equiparação, submete-se a um processo administrativo disciplinar para apuração de suas faltas, o qual cumpre prazos especiais e condições específicas em razão do vínculo temporário com a Administração Pública, em tudo sendo respeitado o devido processo legal, a ampla defesa e o contraditório. Analisam-se as diferenças entre o processo disciplinar do servidor temporário (sindicância) e o processo do servidor público em geral, os ritos adotados, os prazos, as penalidades e os recursos, constatando-se que o servidor público temporário responde pelos atos ilícitos em todas as esferas: penal, civil, administrativa e por atos de improbidade. A transitoriedade na função não o exime de responsabilidades, por isso, com as devidas adaptações, está sujeito aos ônus e bônus do serviço público. Daí a necessidade de construir, com base nas características próprias dessa espécie de servidor público, um regime adaptado às especificações do vínculo especial a que se submete o servidor público temporário. Propõe-se aqui um miniprocesso disciplinar ou um processo disciplinar especial, ou uma minissindicância ou uma sindicância especial, sui generis.

Palavras-chave: Servidor público temporário. Regime jurídico disciplinar. Responsabilidade. Princípio de equiparação. Processo administrativo disciplinar. Sindicância. Regime especial. Artigo 37, IX, da Constituição Federal. Lei n. o 8.745/93. 
BASTOS, Aline Maria Dias. Disciplinary legal regime of temporary public servants. 2014. 266 f. Doctorate - Faculty of Law, University of São Paulo, São Paulo, 2014.

\begin{abstract}
This paper examines at a deeper level the disciplinary legal regime of temporary public servants. Some particularities of this kind of public agent are analyzed in order to identify the main characteristics that differentiate them from other servers thus justifying its particular legal regime. From a brief history of its origin, the presence of temporary servers has been found in the Brazilian Public Administration since 1823. Based on the study of foreign laws, the existence of servants that resemble the Brazilian temporary public servant was detected particularly in French and Portuguese laws. The temporary public servant is a kind of "public servant", a genre of "public agent", who exercises a public function, but does not hold a public office and is not a public employee. This type of servant is hired for a specific time to meet a temporary professional demand of exceptional public interest. As indicated by Article 37, IX of the Brazilian Federal Constitution, a regulatory law must determine the cases of employment for a pre-determined term, and there is no uniformity among Brazilian States about the legal framework adopted for temporary public servants. This study is based on the Brazilian Federal Law number 8.745/93, which governs the matter. At federal level, temporary public servants are covered by a legal regime that is similar to the administrative legal regime. They are hired via an administrative contract that resembles the statutory regime. This contract shall be governed by the observance of the principles of public service continuity, morality, impartiality, reasonableness, proportionality and motivation. Public temporary servers are subject to the administrative proceedings and - through the principle of assimilation - are subject to disciplinary administrative proceedings to investigate their faults, under specific terms and conditions due to their temporary bond with the Public Administration. Such administrative proceedings, however, must follow the rules of the "due legal process", namely the principle of unlimited right of defense and the adversary system. The differences between the disciplinary process of the temporary server (inquiry) and the process of public servants in general are analyzed, as well as the adopted rites, deadlines, penalties and appeals, noting that temporary public employees are liable for torts in all areas: criminal, civil, administrative and acts of misconduct. The transience function does not exempt temporary public servants from liability therefore, mutatis mutandis, they are subject to all rights and obligations of public service. Hence the need to build, based on the characteristics of this kind of public servant, a regime tailored to the specifications of the special bond that undergoes temporary public service. A disciplinary mini-process, or a special disciplinary proceeding, or a small inquiry, or a special sui generis inquiry is proposed herein.
\end{abstract}

Keywords: Temporary public servants. Disciplinary legal regime. Liability. Principle of assimilation. Disciplinary administrative proceedings. Inquiry. Special regime. Article 37, IX of the Brazilian Federal Constitution. Federal Law number 8.745/93. 
BASTOS, Aline Maria Dias. Régime disciplinaire des fonctionnaires temporaires. 2014. 266 f. Doctorat - Faculté de Droit, Université de São Paulo, São Paulo, 2014.

\section{RÉSUMÉ}

Cette thèse vise à approfondir le régime juridique disciplinaire des fontionnaires temporaires. On y présente les principales caractéristiques de ces agents de la fonction publique qui les distinguent des autres et qui entraînent l'application d'un régime disciplinaire particulier. En examinant les origines du fonctionnaire temporaire, on constate qu'ils sont présents dans l'administration publique brésilienne depuis 1823 . Dans le droit étranger (notamment dans le droit français et dans le droit portugais), il y a une figure juridique qui se rapproche du fonctionnaire temporaire brésilien, une espèce de «fonctionnaire » du genre «agent public » qui exerce une fonction publique, mais n'occupe pas de charge ni de poste public, il est engagé pour une durée déterminée pour répondre à un besoin temporaire présentant un intérêt public exceptionnel. Selon l'article 37, IX, de la Constitution fédérale brésilienne, la loi établit les cas dans lesquels des agents sont engagés pour une durée déterminée, mais les entités fédérées brésiliennes n'ont pas harmonisé leur législation en ce qui concerne le régime juridique des agents temporaires. Cette analyse est centrée sur la loi fédérale brésilienne $n$. $^{\circ}$ $8.745 / 93$ qui régit la matière. À l'échelle fédérale, l'agent public temporaire est soumis à un régime juridique dont les caractéristiques se rapprochent de celles du régime juridique administratif ; il est recruté par un contrat administratif semblable au régime statutaire. Ce contrat est régi par les principes de la continuité du service public, de la moralité, de l'impersonnalité, de la raisonnabilité, de la proportionnalité et de la motivation. Cette étude se focalise sur la responsabilité du fonctionnaire temporaire dans les services administratifs. On cherche à démontrer que cet agent, lié à titre temporaire à l'administration publique, en cas de faute grave, en raison du principe d'égalisation, est soumis à une procédure administrative disciplinaire qui obéit à des délais et à des conditions particulières, le tout dans le respect des droits de la défense et $\mathrm{du}$ principe du contradictoire. On analyse les différences entre la procédure administrative disciplinaire appliquée aux agents temporaires (enquête) et la procédure appliquée aux fonctionnaires en général, les rites, les délais, les sanctions et les recours. Le fonctionnaire temporaire répond de ses actes dans tous les domaines: pénal, civil, administratif et en cas de manque de probité administrative. Le caractère temporaire de la fonction n'exempte pas l'agent temporaire de responsabilité, il est soumis aux droits et aux obligations du service public. D'où la nécessité de construire un régime adapté aux caractéristiques du lien spécial qui unit le fonctionnaire temporaire à l'administration publique. On propose une procédure disciplinaire courte ou une procédure disciplinaire spéciale ou une enquête courte, spéciale, sui generis.

Mots-clés: Fonctionnaire temporaire. Régime juridique disciplinaire. Responsabilité. Principe d'égalisation. Procédure administrative disciplinaire. Enquête. Régime spécial. Article 37, IX, de la Constituition fédérale. Loi n. ${ }^{\circ}$ 8.745/93. 


\section{SUMÁRIO}

1 INTRODUÇÃO

2 SERVIDOR PÚBLICO TEMPORÁRIO 15

2.1 HISTÓRICO 15

2.2 CONTRIBUIÇÕES DO DIREITO ESTRANGEIRO 22

$\begin{array}{ll}\text { 2.2.1 Direito francês } & \mathbf{2 3}\end{array}$

2.2.2 Direito português $\quad \mathbf{2 8}$

2.3 CONCEITO DE AGENTES PÚBLICOS E CLASSIFICAÇÃO DO 35

2.3.1 Conceito 35

2.3.2 Classificação 38

2.4 CARGO, EMPREGO OU FUNÇÃO PÚBLICA? 42

2.5 REGIME JURÍDICO FUNCIONAL: CONCEITUAÇÃO DOGMÁTICA E SUA 47 INTEGRAÇÃO AO REGIME CONSTITUCIONAL BRASILEIRO DA ADMINISTRAÇÃO PÚBLICA

2.5.1 Considerações iniciais sobre o regime jurídico 47

2.5.2 Regime estatutário $\quad 49$

2.5.3 Regime trabalhista $\quad 51$

2.5.4 Regime especial $\quad \mathbf{5 4}$

2.6 A NORMA-MATRIZ DA CONTRATAÇÃO TEMPORÁRIA: O ARTIGO 37, 65 IX, DA CONSTITUIÇÃO FEDERAL

2.6.1 Eficácia da norma constitucional $\quad 65$

2.6.2 Competência legislativa concorrente: legislação no âmbito federal, estadual, 69 municipal e distrital

2.6.3 Requisitos constitucionais para a contratação temporária de servidores $\quad 76$ públicos

2.6.3.1 Estipulação de prazo determinado $\quad 76$

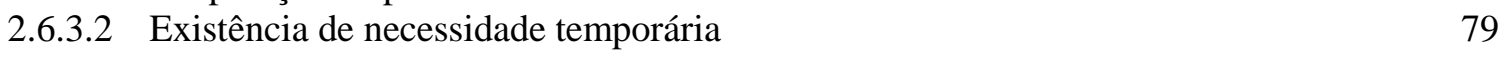

2.6.3.3 Configuração de excepcional interesse público 81

2.6.4 A teoria dos conceitos jurídicos indeterminados e sua aplicação na 85 interpretação constitucional dos pressupostos da necessidade temporária e do excepcional interesse público

2.6.5 A inexigibilidade constitucional de realização de concurso público, nos $\quad 88$ termos do artigo 37, II, da Constituição Federal

2.6.6 Concretização do preceito constitucional no exercício da Administração $\quad 92$ Pública e sua submissão integral à axiologia constitucional

2.6.6.1 Princípio da continuidade do serviço público 94

$\begin{array}{lll}\text { 2.6.6.2 Princípio da moralidade } & 97\end{array}$

2.6.6.3 Princípio da impessoalidade 100

$\begin{array}{ll}\text { 2.6.6.4 Princípio da razoabilidade e da proporcionalidade } & 102\end{array}$

2.6.6.5 Princípio da motivação 106

2.7 CONSIDERAÇÕES SOBRE A LEGISLAÇÃO FEDERAL EM VIGOR E 109 HIPÓTESES DE CONTRATAÇÃO TEMPORÁRIA NO ÂMBITO FEDERAL, A PARTIR DA LEI N. ${ }^{\circ} 8.745 / 93$

2.8 FRAUDE NA INTERPRETAÇÃO E NA APLICAÇÃO DO COMANDO

CONSTITUCIONAL: CONTRATAÇÕES TEMPORÁRIAS INVÁLIDAS 
3 RESPONSABILIDADE DO SERVIDOR PÚBLICO TEMPORÁRIO

3.1 CONSIDERAÇÕES INICIAIS SOBRE RESPONSABILIDADE 123

3.2 FATO JURÍDICO (LATO SENSU) 124

3.2.1 Fato jurídico stricto sensu ou fato natural

3.2.2 Ato jurídico lato sensu ou fato humano 126

$\begin{array}{lll}3.3 & \text { ATO JURÍDICO LÍCITO } & 127\end{array}$

$\begin{array}{ll}\text { 3.3.1 Ato jurídico stricto sensu ou não negocial } & 127\end{array}$

3.3.2 Negócio jurídico ou ato jurídico negocial 128

3.4 ATO ILÍCITO 130

3.4.1 Ilícito administrativo $\quad 132$

$\begin{array}{lll}\text { 3.4.2 Ilícito penal } & 135\end{array}$

3.4.3 Ilícito civil 136

3.4.4 Ilícito por ato de ato de improbidade administrativa 136

3.5 ESPÉCIES DE RESPONSABILIDADE DOS AGENTES PÚBLICOS 138

3.6 INDEPENDÊNCIA DAS INSTÂNCIAS DE RESPONSABILIZAÇÃO CIVIL, 150 PENAL E ADMINISTRATIVA E POR ATO DE IMPROBIDADE

3.7 REPERCUSSÃO DA SENTENÇA PENAL NA INSTÂNCIA DISCIPLINAR E 153 CIVIL

3.8 A RESPONSABILIDADE DO SERVIDOR PÚBLICO TEMPORÁRIO 159

4 REGIME DISCIPLINAR DO SERVIDOR PÚBLICO 165 TEMPORÁRIO

4.1 CONSIDERAÇÕES INICIAIS SOBRE O REGIME DISCIPLINAR 165

4.2 REGIME JURÍDICO DISCIPLINAR DO SERVIDOR PÚBLICO 167

$\begin{array}{ll}\mathbf{4 . 2 . 1} \text { Direitos } & \mathbf{1 6 7}\end{array}$

$\begin{array}{lll}\text { 4.2.2 } & \text { Deveres } & 168\end{array}$

$\begin{array}{lll}\text { 4.2.3 Proibições } & 169\end{array}$

5 PROCESSO ADMINISTRATIVO DISCIPLINAR 172

5.1 PODER DISCIPLINAR: OS PODERES DO ADMINISTRADOR 172

5.2 APURAÇÃO DO ILÍCITO PELA ADMINISTRAÇÃO COM BASE NA LEI 176

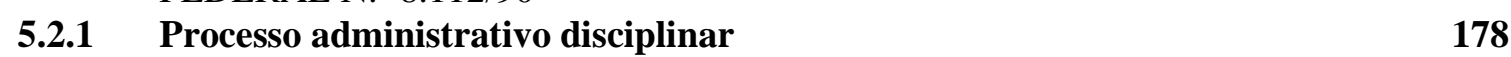

$\begin{array}{lll}\text { 5.2.2 } & \text { Sindicância } & 189\end{array}$

5.2.2.1 Sindicância investigativa, preparatória ou inquisitorial 190

5.2.2.2 Sindicância contraditória, acusatória, autônoma, apuratória ou disciplinar da Lei 192 n. ${ }^{\circ} 8.112$, de 11 de dezembro de 1990

5.2.2.3 Processo administrativo disciplinar decorrente de sindicância disciplinar ou de 195 sindicância preparatória ou conectiva

$\begin{array}{lll}\text { 5.2.3 } & \text { Processo disciplinar sumário } & 196\end{array}$

5.2.3.1 Rito para acumulação ilegal de cargos 197

5.2.3.2 Rito para abandono de cargo e inassiduidade habitual 198 
5.3 CONSIDERAÇÕES SOBRE O DEVIDO PROCESSO LEGAL, O CONTRADITÓRIO E A AMPLA DEFESA

5.3.1 Devido processo legal

5.3.2 Contraditório e ampla defesa

5.4 PENALIDADES

5.5 VIAS RECURSAIS

5.5.1 Controle interno

5.5.2 Controle externo

5.6 PARTICULARIDADES DO PROCESSO DE APURAÇÃO DO ILÍCITO DO

5.6.1 Sindicância (denominação da Lei n. ${ }^{\circ}$ 8.745/93)

6 CONCLUSÕES 


\section{INTRODUÇÃO}

Desvendar o regime jurídico disciplinar do servidor público temporário requer o conhecimento de algumas particularidades dessa espécie de agente público, das características principais que o diferenciam dos demais servidores e que justificam a existência de um regime disciplinar próprio.

A partir de um breve histórico sobre as prováveis origens do temporário, buscar-seá entender a sua razão de ser nos dias atuais.

Examinar-se-ão algumas passagens do direito estrangeiro, notadamente do direito francês, pois a França é o berço do direito administrativo, e do direito português, porque uma parte dos estudos foi realizada em Portugal.

Em primeiro lugar, considera-se o servidor temporário como uma espécie de servidor público do gênero agente público. O servidor temporário exerce uma função pública, mas não ocupa nem cargo, nem emprego públicos.

A maioria dos casos em que se recorre à contratação temporária tem por objetivo solucionar ou minimizar um problema repentinamente surgido. São situações que ultrapassam a normalidade, são contratações provisórias em casos excepcionais, que precisam ser resolvidos imediatamente.

$\mathrm{Na}$ contratação por tempo determinado, parte-se da premissa de que é preciso atender uma necessidade temporária de excepcional interesse público. Como não há tempo para a realização de um processo de concurso público, as pessoas são contratadas por outras formas.

Observa-se que a contratação temporária é bastante utilizada no campo da saúde pública, tendo em vista o aumento do número de médicos, enfermeiros e agentes de saúde. De fato, uma epidemia pode demandar, de forma transitória, a presença de um corpo mais robusto de "servidores públicos". Também houve um incremento de hipóteses na educação, permitindo a contratação de professores.

De acordo com o artigo 37, IX, da Constituição Federal, a lei estabelecerá os casos de contratação por tempo determinado, não havendo, entre os entes da federação brasileira, uma uniformidade do regime jurídico adotado para o servidor temporário. Seria adequado que as normas fossem gerais e que a contratação fosse uniformizada em todo o território nacional, conforme o artigo 22, XXVII, da Constituição Federal. 
O ideal seria que um regime especial de natureza administrativa fosse observado por todos os entes da federação, aplicando os direitos e deveres referidos no respectivo estatuto dos servidores públicos que forem compatíveis com a transitoriedade da contratação (função), por meio de um contrato administrativo.

Mas a realidade não é essa, não há uma uniformidade. Por isso, este estudo analisará a lei federal que disciplina o assunto. Em âmbito federal, o servidor público temporário é dotado de um regime jurídico com características mais próximas do regime jurídico administrativo, sendo recrutado por via de contrato administrativo assemelhado ao regime estatutário. Trata-se, pois, de um regime especial, próprio.

Tal contratação deve pautar-se pelos princípios da continuidade do Serviço Público, da moralidade, da impessoalidade, da razoabilidade, da proporcionalidade e da motivação.

Considera-se estar diante de servidores públicos com direitos, deveres, obrigações e responsabilidades de natureza penal, civil, administrativa e por atos de improbidade administrativa.

Tais servidores estão sujeitos à prática de atos que implicam uma responsabilidade. Os ilícitos administrativos, penais, civis e por atos de improbidade administrativa desencadeiam responsabilidades administrativas, penais, civis e por atos de improbidade administrativa.

Focar-se-á aqui a responsabilidade do servidor público temporário no âmbito administrativo, procurando demonstrar que tal servidor, por um princípio de equiparação, submete-se a um processo administrativo disciplinar (sindicância) para apuração de suas faltas, o qual segue prazos especiais e condições específicas em razão do vínculo temporário com a Administração Pública, em tudo sendo respeitado o devido processo legal, a ampla defesa e o contraditório.

Analisar-se-á como o processo disciplinar do servidor público em geral pode ser aproveitado para a construção do processo disciplinar do servidor temporário (sindicância), quais os ritos adotados, os prazos, as penalidades e os recursos.

O Brasil possui uma quantidade muito grande de servidores públicos temporários, é uma realidade na Administração Pública, mas é preciso organizar a casa, há necessidade de conhecer melhor o regime disciplinar próprio desses servidores, suas peculiaridades e especialidades, de forma a permitir a sua correta aplicação.

$\mathrm{O}$ trabalho está dividido em quatro partes, além desta introdução. Na primeira (capítulo 2), identifica-se quem é o servidor público temporário cujo regime jurídico disciplinar será objeto de estudo, analisando-lhe as origens e pesquisando essa figura no 
direito estrangeiro, notadamente no direito francês e no direito português. Em seguida, partindo-se do conceito de "agente público", apresenta-se sua classificação e seu tratamento no direito positivo brasileiro.

Na segunda parte (capítulo 3), aborda-se a responsabilidade do agente público, especialmente do servidor público temporário. Partindo-se do pressuposto de que a responsabilidade é gerada por um fato ou por um ato (ou omissão), focalizam-se as diversas espécies de ilícito (administrativo, penal, civil e por ato de improbidade administrativa) e a responsabilidade decorrente (discriminando-se as esferas de responsabilidade criminal, administrativa, civil e a decorrente da prática de ato de improbidade administrativa), ressaltando-se a independência das instâncias de responsabilização.

Na terceira parte (capítulo 4), examina-se o regime disciplinar do servidor público temporário com base na Lei n. ${ }^{\circ}$ 8.745/93, analisando-se seus direitos, seus deveres e suas proibições.

$\mathrm{Na}$ quarta parte (capítulo 5), estuda-se o processo administrativo disciplinar aplicável aos servidores públicos federais, com base na Lei n. ${ }^{\circ}$ 8.112/90. A partir desse estudo, estabelecem-se as particularidades do processo de apuração do ilícito do servidor temporário, pois a Lei n. ${ }^{\circ}$ 8.745/93 não prevê um rito processual. Uma vez constatada a responsabilidade do servidor público temporário, após regular processo, observado o contraditório e a ampla defesa, será aplicada uma penalidade. Ao final, enfrenta-se o tema da comunicação das instâncias penal, civil, administrativa e por ato de improbidade administrativa.

Dessa forma, buscar-se-á demonstrar que o servidor público temporário responde pelos atos ilícitos em todas as esferas: penal, civil, administrativa e por atos de improbidade. Será apresentado um regime adaptado às especificações do vínculo especial a que se submete o servidor público temporário. Propõe-se aqui um miniprocesso disciplinar ou um processo disciplinar especial, ou uma minissindicância ou uma sindicância especial, sui generis. A transitoriedade na função não exime esse servidor de responsabilidades, devendo, com as devidas adequações, estar sujeito aos ônus e bônus do serviço público, como se constata na conclusão. 


\section{SERVIDOR PÚBLICO TEMPORÁRIO}

\subsection{HISTÓRICO}

$\mathrm{Na}$ origem dos atuais servidores públicos temporários, encontram-se os chamados extranumerários. É importante buscar conhecer a história e voltar ao tempo em que tudo começou para entender a razão da existência dos servidores públicos temporários e verificar as derivações da figura inicial desenhada.

Após a pesquisa em leis antigas e autores que fazem referência aos ancestrais do servidor temporário (extranumerário), colacionaram-se alguns escritos que auxiliarão no desenvolvimento do trabalho.

Tem-se notícia da presença do extranumerário desde as leis imperiais. José Augusto de Carvalho e Melo observa em seu estudo sobre o extranumerário:

O extranumerário sempre mourejou nos serviços públicos, embora sem essa literal denominação genérica que, de tempos a esta parte, o assinala, distingue, qualifica e define. Trata-se, como se verá, de antigo tipo de servidor do Estado, bastante familiar às leis do Império; trata-se de profissional encontradiço em setores diversos da administração de antanho.

Com efeito. Através de várias décadas, ou, melhor, de mais de um século, vem êle colaborando, anônimamente com o funcionalismo público ${ }^{1}$.

Furtado de Mendonça refere-se a "agentes auxiliares" e, com fundamento em leis de 20 de outubro de 1823 , de $1 .^{\circ}$ de outubro de 1828, de 18 de agosto de 1831, e em avisos de 1849, 1851 e 1852, afirma: "Êstes se dividem [...], quanto ao tempo, em permanentes, temporários e acidentais e, quanto ao grao de autoridade, sem caracter algum official, ou com título e qualidade em certos casos e para com certas pessoas",2.

José Augusto de Carvalho e Melo constata que o extranumerário foi previsto de forma regular, com todas as suas características. Ressalta que não é apenas isso que se tem como registro e anota, com muita propriedade:

[...] Rápida consulta às obsoletas leis imperiais demonstrará que não surgiu êle por mero acaso, eventualmente, acidentalmente. Não foi, como não é, elemento de origem duvidosa, ou ignorada, paraquedista, estranho à administração do país. Não foi planta exótica e tampouco produto de enxertos ocasionais. Não emergiu por obra e graça de injunções políticas, ou subalternas. Não medrou à margem da lei, nem viveu contra suas

\footnotetext{
${ }^{1}$ MELO, José Augusto de Carvalho e. Extranumerário. Revista de Direito Administrativo, Rio de Janeiro, v. 1 , jan. 1945 , p. 347.

${ }^{2}$ MENDONÇA, Francisco Maria de Souza Furtado de. Excerto de direito administrativo pátrio. [S.l.: s.n.], 1865 , p. 56-57.
} 
normas. Muito pelo contrário, apareceu regularmente, fora do quadro de empregados públicos, e, desde logo, com indicações precisas do modo de ser admitido, do prazo de sua permanência nos serviços, da natureza dos trabalhos que lhe cumpria executar e da forma da respectiva retribuição ${ }^{3}$.

O autor acima referido cita como exemplo o Regulamento da Casa da Moeda, aprovado pelo Decreto n. ${ }^{\circ} 2.537$, de 2 de março de 1860 . Nele há expressa referência aos funcionários ou empregados que iriam constituir o pessoal daquele importante órgão. Está disposto no artigo 52, § 1.': "Excetuam-se os que servirem por contrato, cujas condições serão cumpridas como nêle se contiverem".

O Decreto-Lei n. ${ }^{\circ} 8.227$, de 24 de agosto de 1881, já estabelecia regras para a contratação de professores interinos para os quadros do Imperial Colégio de Pedro II: professores substitutos. Isso é um indício da normatização da subespécie de servidor público temporário.

O Decreto n. ${ }^{\circ}$ 5.426, de 7 de janeiro de 1928, alterou o dispositivo do Código de Contabilidade e enfrentou a tarefa de situar em dois grupos distintos o funcionário e o extranumerário.

A primeira referência expressa ao extranumerário encontra-se na Lei n. ${ }^{\circ}$ 284, de 28 de outubro de 1936, que, em seu artigo 19, dispõe: “Os serviços públicos civis serão executados pelos funcionários cujos cargos constam das tabelas anexas a esta lei e por pessoal extranumerário".

Edmir Netto de Araújo, ao tratar dos extranumerários, esclarece: "Tais servidores não eram considerados incluídos no quadro regular de funcionários, mas em grupamento acessório, modificável por decreto, e recrutados por designação, admissão ou contratação precárias, sem estabilizar-se nas funções, como ocorria nos cargos"4.

Em seguida, o Decreto-Lei n. ${ }^{\circ}$ 240, de 4 de fevereiro de 1938, em seu artigo 3. ${ }^{\circ}$, divide os extranumerários em quatro espécies: contratados, mensalistas, diaristas e tarefeiros.

Themístocles Brandão Cavalcanti observa que, no Decreto-Lei n. ${ }^{\circ} 240$, de 4 de fevereiro de 1938, esquiva-se ao uso do termo "funcionário", é utilizada a palavra "pessoal”, a fim de evitar a equiparação do agente extranumerário ao agente estatutário, visto que o último era chamado "funcionário",

\footnotetext{
${ }^{3}$ MELO, 1945, p. 347,

${ }^{4}$ ARAÚJO, Edmir Netto de. Curso de direito administrativo. 6. ed. São Paulo: Saraiva, 2014, p. 295.

${ }^{5}$ CAVAlCANTI, Themístocles Brandão. Tratado de direito administrativo. 3. ed. Rio de Janeiro: Freitas Bastos, 1956, v. 4, p. 87.
} 
Assim, à nossa lei sobre extranumerários (Decreto-Lei n. 240, de 4-21938) pode-se denominar estatuto especial porque compreende uma categoria de servidores do Estado que não se acham incluídos no quadro geral, embora não se deva excluir, de todo, a aplicação aos extranumerários das normas gerais ${ }^{6}$.

A tendência anterior, como veremos, era no sentido de assegurar os mesmos direitos, garantias e vantagens aos funcionários hoje compreendidos na classe de extranumerários ${ }^{7}$.

Nota-se que, já naquela época, falava-se em estatuto especial dos extranumerários, sem excluí-los totalmente do quadro geral de funcionários, pois havia a aplicação das normas gerais aos extranumerários, assegurando-lhes os mesmos direitos, garantias e vantagens dos funcionários do quadro geral ${ }^{8}$.

Dessa forma, foram concedidos direitos e vantagens aos extranumerários pelos seguintes textos legais:

a) Decreto-Lei n. ${ }^{\circ} 3.768$, de 28 de outubro de 1941, que concedeu aposentadoria aos extranumerários;

b) Decreto-Lei n. ${ }^{\circ}$ 5.175, de 7 de janeiro de 1943, que estendeu aos extranumerários as normas do Estatuto dos Funcionários Públicos Civis da União, referentes aos deveres e à ação disciplinar, dispondo sobre os institutos da transferência, da readmissão e da reversão;

c) Decreto-Lei n. ${ }^{\circ}$ 5.631, de 27 de julho de 1944, que concedeu licenças e férias aos extranumerários;

d) Decreto-Lei n. ${ }^{\circ}$ 7.502, de 30 de abril de 1945, que concedeu diárias aos extranumerários;

e) Decreto-Lei n. ${ }^{\circ}$ 9.166, de 12 de abril de 1946, que permitiu o exercício de cargo de provimento em comissão.

Observa-se, que a aproximação jurídica entre os servidores estatutários e os extranumerários torna-se mais forte.

Ao tratar dos extranumerários, Themístocles Brandão Cavalcanti defende o seguinte ponto de vista:

[...] êles são funcionários, com garantias limitadas, nomeados a título precário, dentro de diferentes modalidades criadas pela própria lei.

\footnotetext{
${ }^{6}$ CAVALCANTI, 1956, v. 4, p. 37.

${ }^{7}$ CAVALCANTI, 1956, v. 4, p. 60.

${ }^{8}$ A presente tese, baseada nas origens do servidor temporário e nas características apresentadas na legislação analisada, defende que os servidores temporários são servidores públicos pertencentes a um regime especial, de cunho jurídico-administrativo, mais próximo do regime estatutário.
} 
O processo de seleção dêsse pessoal deve atender muito a consideração de ordem técnica, dando-se preferência a indivíduos especializados, cuja competência possa ser apurada, independente de concurso por demais rigoroso ou compreensivo de muitas matérias, como no provimento dos cargos efetivos ${ }^{9}$.

A primeira Constituição brasileira que se referiu aos extranumerários foi a Constituição de $1946^{10}$.

André Prado de Vasconcelos entende que houve uma total descaracterização do regime a que os extranumerários estavam sujeitos:

A Constituição de 1946, por intermédio do Ato das Disposições Constitucionais Transitórias, equiparou a funcionários aqueles que vinham exercendo funções de natureza permanente há mais de cinco anos, ou que foram admitidos em virtude de concurso ou prova de habilitação, para efeito de estabilidade, aposentadoria, licença, disponibilidade e férias ${ }^{11}$.

A Lei n. ${ }^{\circ} 1.711$, de 28 de outubro de 1952, considerada como "o novo estatuto dos funcionários públicos", estendeu o regime jurídico ali previsto aos extranumerários amparados pela Constituição Federal de 1946 e aos demais extranumerários no que coubesse.

A Lei n. ${ }^{\circ} 1.890$, de 16 de junho de 1953, tentou submeter os extranumerários ao regime da Consolidação das Leis do Trabalho, mas os extranumerários já se encontravam equiparados aos funcionários, em razão do estatuto de 1952.

Para Raphael Diógenes Serafim Vieira, a ideia de os servidores extranumerários possuírem natureza celetista justifica-se tão somente em uma análise situada na fase do pós-golpe de 1964, em que se notou a tendência ampliadora dos limites da Consolidação das Leis do Trabalho ${ }^{12}$.

André Prado de Vasconcelos, ao defender o regime celetista como o mais apropriado para os servidores temporários, afirma:

\footnotetext{
${ }^{9}$ CAVALCANTI, 1956, v. 4, p. 88.

${ }^{10}$ No Ato das disposições constitucionais transitórias, lê-se: “Art. 23 Os atuais funcionários interinos da União, dos Estados e Municípios, que contem, pelo menos, cinco anos de exercício, serão automaticamente efetivados na data da promulgação deste Ato; e os atuais extranumerários que exerçam função de caráter permanente há mais de cinco anos ou em virtude de concurso ou prova de habilitação serão equiparados aos funcionários, para efeito de estabilidade, aposentadoria, licença, disponibilidade e férias".

11 VASCONCELOS, André Prado de. Contratação por tempo determinado para atender à necessidade temporária de excepcional interesse público com adoção de parcela das disposições do regime estatutário: regime especial ou burla à norma constitucional insculpida no art. 37, inciso II, da Constituição Federal de 1988. Revista do Tribunal Regional Federal da $1^{a}$ Região, Brasília, DF, v. 15, n. 2, fev. 2003, p. 54.

${ }^{12}$ VIEIRA, Raphael Diógenes Serafim. Servidor público temporário: natureza jurídica, regime, contratação irregular e a (não) incidência do princípio primazia da realidade de fato sobre as formas. Viçosa: UFV, 2007, p. 51.
} 
Com a revolução militar, inicia-se a reforma administrativa quando são editados vários textos legais que demonstram a nítida tendência de universalizar o uso do regime celetista eliminando o regime dos extranumerários, a saber: Lei 5.173/66 (art. 58); o Decreto-Lei 161/66 (art. 19 a 22), o Decreto-Lei 224/67 ( $4^{\circ} .^{\circ}$ do art. 5. ${ }^{\circ}$ ), o Decreto-Lei 225/67 (art. 6. ${ }^{\circ}$ ), o Decreto-Lei 281/67, o Decreto-Lei 301 e o próprio Decreto-Lei 200/67 que dispõe que nos termos da legislação trabalhista poderão ser contratados especialistas para atender as exigências de trabalho técnico em institutos, órgãos de pesquisa e outras entidades especializadas da Administração direta ou autárquica, segundo os critérios que, para esse fim, seriam estabelecidos em regulamento ${ }^{13}$.

Adilson Abreu Dallari alerta:

não obstante suficientemente demonstradas a eventualidade e a precariedade inerentes à admissão de tais servidores, na prática isso não ocorria, especialmente no que se referia aos extranumerários, que eram, posteriormente, estabilizados ${ }^{14}$, o que passou a ser uma forma de, pura e simplesmente, burlar a exigência de concurso público ${ }^{15}$.

Burlar o concurso público seria uma forma de escapar ao regime de direito público.

No dizer de Maria João Estorninho, ocorreria uma fuga para o Direito Privado, ou seja, "aquelas situações nas quais a Administração Pública adopta as formas de organização e/ou as formas de actuação jurídico-privadas, para com isso se furtar ao regime de direito público a que normalmente está sujeita"16.

Edmir Netto de Araújo compartilha do mesmo entendimento de Adílson Abreu Dallari e ressalta:

No regime anterior à Constituição de 1967, o exercício de funções foi ainda mais associado à temporariedade ou interinidade, integrando quadros de funções, à parte dos quadros regulares de cargos, entendendose por interinos aqueles que substituíam funcionários do quadro, afastados, ou para preenchimento de cargos ainda não providos por concurso, sendo os extranumerários admitidos a título precário para funções eventuais ou extraordinárias, sempre sem necessidade de lei para criação das funções ou de concurso público para seu preenchimento, pois, embora recebessem, no exercício das funções, tratamento quase idêntico ao dos funcionários titulares de cargos, jamais adquiriam estabilidade.

Todavia, a estabilização extraordinária após dois anos de exercício foi utilizada (com apoio jurisprudencial) como forma de burlar a exigência de concurso público, e perdurou até a Carta de 1967 que, apesar de estabilizar extraordinariamente certos ocupantes de funções, fechou a porta às estabilizações sem concurso $\left(\mathrm{CF}\right.$, art. $\left.99, \S 1 .^{\circ}\right)$, e mesmo para nomeação efetiva, sem concurso ( $\operatorname{art.} 95, \S 10^{\circ}$ ), para cargos públicos.

\footnotetext{
${ }^{13}$ VASCONCELOS, 2003, p. 55.

${ }^{14}$ Tal estabilização dos servidores temporários é uma burla ao concurso público e não deve ocorrer, pois é uma afronta à Constituição Federal (CF).

${ }^{15}$ DALLARI, Adilson Abreu. Regime constitucional dos servidores públicos. 2. ed. São Paulo: Revista dos Tribunais, 1990, p. 120.

${ }^{16}$ ESTORNINHO, Maria João. A fuga para o direito privado: contributo para o estudo da actividade de direito privado da Administração Pública. 2 reimpr. Coimbra: Almedina, 2009, p. 17.
} 
Mas os textos constitucionais posteriores (inclusive estaduais) agasalhavam estabilizações extraordinárias, até mesmo a Constituição vigente (p. ex., art. 19 do ADCT) ${ }^{17}$.

Classificando a Constituição de 1967 de bastante moralizadora, Adilson Abreu Dallari afirma que a referida Constituição veio colocar um ponto final nessa situação, “extinguindo a possibilidade de admissão de pessoal para ocupar cargo público sem prévia aprovação em concurso, o que passou a ser também requisito indispensável para aquisição da estabilidade (arts. 95, § 1..$^{\circ}$, e 99, § 1. $\left.{ }^{\circ}\right)^{\text {,18 }}$. O artigo 104 da Constituição de 1967 dispunha: "aplica-se a legislação trabalhista aos servidores admitidos temporariamente para obras, ou contratados para funções de natureza técnica ou especializada”.

Assim, a Carta de 1967 (artigo 104) indicava a preferência pelo regime trabalhista para admissões temporárias para obras, ou para funções de natureza técnica ou especializada, ligando tal regime à noção de função ${ }^{19}$.

Mas isso foi modificado na Emenda Constitucional (EC) n. ${ }^{\circ}$ 01/69, que, em seu artigo 106, dispõe: “o regime jurídico dos servidores admitidos em caráter temporário ou contratados para funções de natureza técnica especializada será estabelecido em lei especial". Portanto, determinou "lei especial" para o regime jurídico dos temporários, o qual passou a ser o estatutário (entretanto, sem atribuição de estabilidade), e a qualquer serviço temporário (não só para obras), sendo tais agentes ocupantes de funções, não de cargos.

Nesse momento, com a Emenda Constitucional n. ${ }^{\circ}$ 01/69 foi desenhado o seguinte cenário para os temporários: havia uma lei especial para o regime jurídico dos temporários - o regime estatutário sem atribuição de estabilidade -, e tais agentes ocupavam funções e não cargos.

O estudo de Celso Antônio Bandeira de Mello a respeito do artigo 106 conclui:

Parece-nos que o texto do art. 106 visa tão-só afastar a possibilidade de admissões temporárias ou para funções de natureza especializada, subordinadas a regime idêntico ao do funcionalismo. Sendo assim, a lei competente para disciplina de tais servidores será estadual, municipal ou federal, conforme a pessoa jurídica que reclame os mencionados serviços. A única limitação é a impossibilidade de estender aos admitidos para tais atividades a mesma legislação aplicável aos seus funcionários. Desejou a Lei Magna, de um lado, afastar a aplicação obrigatória das normas trabalhistas e, de outro, obstar a atribuição dos mesmos direitos funcionais ou equiparações que viessem a nivelar funcionários e servidores admitidos para os serviços referidos. Sendo esta - segundo

\footnotetext{
${ }^{17}$ ARAÚJO, 2014, p. 295-296, grifos do autor.

${ }^{18}$ DALLARI, 1990, p. 120.

19 ARAÚJO, 2014, p. 296.
} 
entendemos - a intenção do texto, e apenas esta, nada autoriza a supor que o regime destes servidores seja o estabelecido em lei federal, para tal fim editada ${ }^{20}$.

Bem lembra Edmir Netto de Araújo:

Acontece que a União, a partir da Lei n. 6.185, de 11 de dezembro de 1974, e do Decreto n. 75.627, de 18 de abril de 1975, passou a utilizar preferencialmente o regime celetista na Administração Indireta e mesmo na Direta, inclusive para atividades de assessoramento e assistência, com exceção dos cargos destinados a atividades inerentes ao Estado como "Poder Público" (as assim chamadas "funções de serviço público"), tais como as da área de representação judicial (Procuradorias), tributação, segurança pública, Ministério Público, diplomacia. Essa situação perdurou até a Lei n. 8.112, de 11 de dezembro de 1990, de forma que burlou a exigência de concurso público para a estabilização firmada pelo art. 41 da CF, transformou os empregos da Administração Direta, autarquia e fundações "públicas" em cargos públicos, estatutários e estáveis $^{21}$.

Diante desse panorama histórico, a Constituição Federal de 1988 trouxe o inciso IX do artigo 37: "A lei estabelecerá os casos de contratação por tempo determinado para atender a necessidade de excepcional interesse público".

Cármen Lúcia Antunes Rocha ressalta a importância do inciso:

Previsto constitucionalmente no art. 37, IX, da Lei Maior, a matéria contém-se como necessária ao desempenho das entidades públicas, para as quais surge, eventualmente, necessidade temporária que não impõe, pela sua provisoriedade, a existência de cargo, mas que importa em imprescindibilidade de desempenho ${ }^{22}$.

Na visão de André Prado de Vasconcelos, com a promulgação da Constituição de 1988, houve um rompimento com o regime instituído por intermédio do artigo 106 da Emenda Constitucional n. ${ }^{\circ}$ 01/69, visto que as hipóteses de autorização para a existência de um terceiro regime jurídico ficaram reduzidas aos "casos de contratação por tempo determinado para atender necessidade temporária de excepcional interesse público"23.

$\mathrm{O}$ artigo 37, IX, da Constituição Federal foi regulamentado pela Lei Federal n. ${ }^{\circ}$ 8.112/90, sendo atribuída aos servidores temporários a natureza jurídica de um verdadeiro contrato civil de locação de serviços (artigo 232 da Lei n. ${ }^{\circ}$ 8.112/90).

Ocorre que, ao falar em locação de serviços (disciplinada pelos artigos 1.216 a 1.236 do Código Civil, Lei n. 3.071 , de $1 .^{\circ}$ de janeiro de 1916) como modalidade

${ }^{20}$ MELLO, Celso Antônio Bandeira de. Apontamentos sobre os agentes e órgãos públicos. São Paulo: Revista dos Tribunais, 1987 , p. 57-58.

${ }^{21}$ ARAÚJO, 2014, p. 296, grifos do autor.

22 ROCHA, Cármen Lúcia Antunes. Princípios constitucionais dos servidores públicos. São Paulo: Saraiva, 1999 , p. 241.

${ }^{23}$ VASCONCELOS, 2003, p. 60. 
contratual prevalente nos casos de prestação temporária de trabalho, o legislador direcionou para o campo do Direito Civil a regência da matéria.

Nesse contexto, a Lei Federal n. ${ }^{\circ}$ 8.745, de 9 de dezembro de 1993, veio revogar os artigos 232 a 235 da Lei n. ${ }^{\circ}$ 8.112/90 (Título VII, Capítulo Único - Da Contratação Temporária de Excepcional Interesse Público), instituindo um terceiro regime para a contratação de servidores temporários.

$\mathrm{O}$ artigo 11 da Lei Federal n. ${ }^{\circ}$ 8.745/93 estendeu aos contratados temporários uma série de direitos e deveres previstos na Lei n. ${ }^{\circ}$ 8.112/90 para os servidores estáveis. Os servidores temporários passaram a ter direito a ajuda de custo, diárias, gratificação natalina, adicional por tempo de serviço, adicionais de insalubridade, periculosidade e atividades penosas, adicional por serviço extraordinário, adicional noturno, adicional de férias, férias, licença para ausentar-se do serviço para doar sangue, para alistar-se como eleitor e para casar, licença em virtude de falecimento de cônjuge, companheiro, pais, madrasta ou padrasto, filhos, enteados e menor sob guarda ou tutela e irmãos, além do direito de petição.

O artigo 8. ${ }^{\circ}$ da Lei n. ${ }^{\circ}$ 8.745/93 remete à Lei n. ${ }^{\circ}$ 8.647, de 13 de abril de 1993, que vincula tais servidores ao Regime Geral de Previdência Social.

A Lei n. ${ }^{\circ}$ 9.849, de 26 de outubro de 1999, apenas ampliou o universo de funções públicas compreendidas no rol regulado pela Lei n. ${ }^{\circ}$ 8.745/93.

Pelo menos no âmbito federal, observa-se que o regime especial dos temporários tende a aproximar-se mais do regime estatutário do que do regime celetista ${ }^{24}$.

Como se pode constatar, a origem da figura dos temporários é bastante antiga em nossa legislação. Embora a nomenclatura tenha sido alterada, a ideia do servidor temporário é a mesma, com pequenas variações que merecem ser estudadas e analisadas de forma a extrair a sua essência para melhor compreender as implicações e os reflexos no regime disciplinar do servidor público temporário.

\subsection{CONTRIBUIÇÕES DO DIREITO ESTRANGEIRO}

Tivemos notícia da existência de figura assemelhada aos temporários em outros países. Aqui serão estudadas as realidades da França e de Portugal.

\footnotetext{
${ }^{24} \mathrm{O}$ assunto será estudado com mais pormenores na subseção 2.5 .
} 


\subsubsection{Direito francês}

Na França, Jean-Marie Auby e Robert Ducos-Ader fazem referência à figura dos agentes temporários.

Esses agentes ocupam empregos temporários criados durante a guerra ou por ocasião de diversas intervenções do governo na economia. Trata-se igualmente de agentes "adjuvantes", recrutados para certas necessidades sazonais, de agentes substitutos ou interinos. Às vezes, alguns agentes temporários são lotados em postos de trabalho permanentes. Em geral, eles possuem a qualidade de agentes públicos, mas não a de funcionários, uma vez que a condição relativa à ocupação de um trabalho permanente não foi atendida. Alguns textos permitem na verdade a esses agentes obter sua titularidade ${ }^{25}$.

No direito francês, o termo "funcionário" é bastante impreciso. Na linguagem corrente, ele designa, se não todo o pessoal da administração, pelo menos aqueles sujeitos a um regime de direito público: trata-se, na verdade, de agentes públicos. Na linguagem jurídica, existem várias noções de funcionários que não coincidem. Nesse sentido, alguns artigos do Código Civil (artigos 106 e 107 sobre domicílio, artigo 427 sobre tutela) ou do Código Penal empregam o vocábulo "funcionário". As jurisdições civis e criminais sentiram necessidade, para a aplicação desses artigos, de precisar a noção de funcionário ${ }^{26}$.

Do mesmo modo, algumas decisões do Conselho de Estado ou do Tribunal de Conflitos chegaram à seguinte definição de funcionário: "agente investido de emprego permanente no serviço público" ou "agente nomeado em emprego permanente no quadro da administração pública". Na realidade, mesmo que haja elementos da noção de funcionário retidos nesses artigos de lei, não se pode considerar que exista uma definição geral e absoluta de funcionário.

A noção de funcionário deve ser vista como uma noção essencialmente relativa. Um agente não é, em geral, funcionário; ele é funcionário com base em algum artigo de lei ou de alguma norma; em diferentes casos, as definições citadas, mesmo tendo alguns pontos em comum, podem não coincidir.

Esse princípio continua a valer desde o estabelecimento do estatuto de 1983-1986. A definição de funcionário não é exatamente a mesma quando se trata de função pública do Estado ou de função pública local (territorial) ou da função pública hospitalar ${ }^{27}$.

\footnotetext{
${ }^{25}$ AUBY, Jean-Marie; DUCOS-ADER, Robert. Droit administratif. 7. éd. Paris: Dalloz, 1986, p. 35.

${ }^{26}$ AUBY, Jean-Marie et al. Droit de la fonction publique. 7. éd. Paris: Dalloz, 2012, p. 41-42.

${ }^{27}$ AUBY et al., 2012, p. 42.
} 
Como se pode notar, a noção de agente público, na França, não é simples, é marcada pelo paradoxo e pela incerteza. Compreende agentes titulares - os funcionários e agentes não titulares. Entre eles, há um ponto comum: agem em nome de uma pessoa pública e são submetidos a um regime jurídico distinto do direito comum de trabalho ${ }^{28}$.

O funcionário é uma pessoa nomeada para um emprego permanente e efetivada em um grau de hierarquia da Administração do Estado, dos órgãos exteriores a ela vinculados ou de estabelecimentos públicos (autarquias) do Estado (versão inicial do artigo 2. ${ }^{\circ}$ da Lei n. ${ }^{\circ} 84-16$, de 11 de janeiro de 1984, Lei n. ${ }^{\circ} 84-53$, de 26 de janeiro de 1984, e Lei n. ${ }^{\circ} 86-$ 33, de 9 de janeiro de 1986, e títulos II, III e IV do estatuto geral dos funcionários). Os funcionários ocupam uma posição estatutária e são regidos por leis e regulamentos. Os agentes não titulares são, ao contrário, ligados à Administração por um contrato de direito público com duração determinada ou indeterminada.

De acordo com a versão inicial do artigo 2..$^{\circ}$ da Lei de 11 de fevereiro de 1984, que rege a função pública do Estado e à qual remete o título II do Estatuto Geral dos Funcionários, o funcionário estatal é assim definido:

O presente título aplica-se às pessoas que, regidas pelo disposto no título I do Estatuto Geral, foram nomeadas para um emprego permanente de tempo integral e efetivadas em um grau de hierarquia da administração central do Estado, dos órgãos exteriores a ela vinculados ou de estabelecimentos públicos [autarquias] do Estado $^{29}$.

Segundo a versão mais recente do artigo $2 .^{\circ}$ da Lei n. $.^{\circ} 84-16$ (modificado pela Lei n. ${ }^{\circ}$ 92-125, de 6 de fevereiro de 1992, publicada no Diário Oficial da República Francesa (JORF) de 8 de fevereiro de 1992), o funcionário é uma pessoa nomeada para um emprego permanente e efetivada em um grau de hierarquia da Administração do Estado, dos órgãos descentralizados a ela vinculados ou de estabelecimentos públicos (autarquias) do Estado $^{30}$.

\footnotetext{
${ }^{28}$ GONOD, Pascale; MELLERAY, Fabrice; YOLKA, Philippe. Traité de droit administratif. Paris: Dalloz, 2011, t. II, p. 344-345.

${ }^{29}$ Essa definição compreende os seguintes elementos: a) o funcionário é recrutado por via de nomeação, isto é, mediante ato unilateral da administração, o agente recrutado por contrato não sendo, portanto, funcionário; b) o emprego do funcionário deve ser um emprego permanente, a jurisprudência exigindo igualmente uma ocupação permanente - a lei exige que se trate de um emprego permanente de tempo integral (o que não exclui a possibilidade de o posto ser ocupado por um funcionário que trabalhe em tempo parcial); c) a efetivação é feita em um grau de hierarquia administrativa - elemento essencial para distinguir os funcionários dos agentes não titulares; d) há a participação em um serviço público do Estado (administração central e órgãos exteriores) ou em autarquias nacionais. No que se refere aos serviços públicos industriais e comerciais, cabe lembrar aqui que somente podem ser funcionários os agentes públicos desses serviços (ou seja, os diretores e contadores) (AUBY et al., 2012, p. 42-43).

${ }^{30} \mathrm{Ver}<\mathrm{http}: / / \mathrm{ww}$.legifrance.gouv.fr/affichTexte.do?cidTexte=JORFTEXT000000501099> (grifo nosso).
} 
A definição de funcionários públicos no sentido da função pública territorial ${ }^{31} \mathrm{e}$ da função pública hospitalar ${ }^{32}$ é muito próxima da definição dada pelos textos para a função pública do Estado, mas não é idêntica.

Como se pode constatar, esses dois estatutos admitem a hipótese de funcionários trabalharem em tempo parcial (incompleto), situação tradicionalmente incomum na função pública do Estado. É admitida hoje pelas leis, mas é pouco praticada.

Os agentes públicos não titulares do Estado são agentes públicos que, por não preencherem as condições previstas no artigo 2. ${ }^{\circ}$ do Estatuto de 1984, não são considerados funcionários. Enquadram-se nessa categoria agentes em diferentes situações: estagiários, auxiliares, contratados, temporários, interinos e certas categorias de trabalhadores. Alguns estão sujeitos a um estatuto bastante abrangente. Outros, chamados erroneamente "sem estatuto", estão sujeitos a algumas regras ${ }^{33}$.

Para assumir certas tarefas, geralmente temporárias ou sazonais, as Administrações podem recrutar agentes temporários ou interinos. $O$ recrutamento de interinos foi facilitado pela lei de 3 de agosto de 2009 relativa à mobilidade e à trajetória profissional na função pública.

O fato de esses agentes cumprirem tarefas de caráter temporário não os impede de ter a qualidade de agente público conforme os critérios que regem essa qualificação.

Os funcionários não titulares não gozam de uma proteção estatutária forte como os funcionários: notadamente, não são efetivados em um grau e não têm a garantia de emprego que incide sobre esse mecanismo.

Há na França as figuras do colaborador beneficente da Administração e do colaborador requisitado ou trabalhador requisitado que, num primeiro momento, poderia equivaler ao nosso servidor temporário, mas a análise de suas características permite afirmar que se trata de figuras distintas.

A figura do colaborador beneficente é uma criação da jurisprudência. Refere-se a pessoas que, sem pertencer ao pessoal administrativo, cooperam, de forma voluntária, com

\footnotetext{
${ }^{31}$ Em relação à função pública territorial, o artigo 2 da lei de 26 de janeiro de 1984 visa "as pessoas que, regidas pelo título 1 do Estatuto Geral dos Funcionários do Estado e das coletividades territoriais, foram nomeadas para um emprego permanente e efetivadas em um grau da hierarquia administrativa das comunas, dos departamentos, das regiões ou de seus estabelecimentos públicos [autarquias públicas], bem como dos serviços públicos de habitação social e das caixas de crédito municipal, com exceção, para esses últimos, dos diretores e dos agentes contábeis" (AUBY et al., 2012, p. 43).

${ }^{32}$ No que tange à função pública hospitalar, o artigo 2 da lei de 9 de janeiro de 1986 visa as "pessoas que, regidas pelas disposições do título primeiro do Estatuto Geral, foram nomeadas para um emprego permanente em tempo integral ou em tempo não integral cuja cota de trabalho é pelo menos igual à meia jornada e efetivadas em um grau da hierarquia dos estabelecimentos públicos [...]" (AUBY et al., 2012, p. 43).

${ }^{33}$ AUBY et al., 2012, p. 43-46.
} 
as autoridades administrativas na execução de uma tarefa de interesse público: algumas salvaguardas surgem dessa colaboração ${ }^{34}$.

A qualidade de colaborador beneficente pode ser reconhecida, por exemplo, na pessoa que participa, sem ser requisitada, da luta contra um incêndio.

A jurisprudência reconhece várias consequências desse reconhecimento. Em caso de danos físicos no decurso de sua atividade, o colaborador beneficente pode obter uma compensação da administração sem ter de provar sua culpa.

A colaboração pode ser solicitada pela Administração ou imposta pelas circunstâncias. O colaborador tem de agir segundo um interesse público, e não em interesse próprio, e não pode ter sofrido o dano quando estava em situação de usuário do serviço público.

Ao ato do colaborador beneficente, pode ser aplicada a teoria do funcionário de fato, sendo considerado como ato administrativo regular.

O colaborador beneficente não faz parte do pessoal da Administração. Não goza dos benefícios profissionais desse grupo, como proventos ou efetivação. Não está submetido aos direitos e obrigações aplicáveis aos agentes públicos.

$\mathrm{Na}$ França, há a figura dos colaboradores requisitados ${ }^{35}$. Trata-se de pessoas cuja colaboração é exigida pelas autoridades administrativas sob pena de sanções. Geralmente, a requisição é feita em tempo de guerra ou de tensão internacional (leis de 5 de julho de 1877, de 11 de julho de 1958 e de 6 de janeiro de 1959 e decreto de 26 de março de 1962), ou em tempo de paz, em razão de incêndios ou de calamidades públicas (artigo R. 20-12 do Código Penal e artigo L. 2112-2 do Código Geral das Coletividades Territoriais). Existem vários outros casos em que os particulares são chamados para atuar no serviço público: jurados durante os julgamentos, testemunhas em tribunal, advogados.

A função pública francesa é organizada preponderantemente pelo sistema de carreira. No sistema de carreira, o funcionário não é contratado para um emprego determinado; já no sistema de emprego, o funcionário é contratado para um emprego determinado.

Os dispositivos do Código do Trabalho não se aplicam aos agentes de direito público empregados por pessoas de direito público. Não há um sistema jurídico no qual os funcionários da Administração estão sujeitos e completamente submetidos ao direito comum do trabalho.

\footnotetext{
${ }^{34}$ AUBY et al., 2012, p. 33.

${ }^{35}$ AUBY et al., 2012, p. 34-35.
} 
A Lei n. ${ }^{\circ}$ 2008-126, de 13 de fevereiro de 2008, trata da reforma da organização do serviço público de emprego.

As reformas legislativas e regulamentares do direito da função pública revelam que, depois de alguns anos, houve uma certa propensão para importar soluções próprias do direito do trabalho.

O Conselho de Estado utiliza o direito do trabalho para preencher a situação de lacuna de agentes não titulares e isola os princípios gerais que inspiram o Código do Trabalho.

O direito comunitário tem uma influência sobre certos dispositivos do direito da função pública. Assim, é em nome de sua aplicação que a possibilidade de pronúncia sobre os contratos de duração indeterminada foi introduzida na função pública pela Lei n. ${ }^{\circ}$ 2005843, de 26 de julho de 2005, que estabelece diversas medidas de transposição do direito comunitário para a função pública a fim de limitar as renovações sucessivas de contratos de duração determinada ${ }^{36}$.

O direito comunitário produziu igualmente efeitos pela aplicação do princípio da livre circulação de trabalhadores constantes do antigo Tratado da Comunidade Europeia (artigo 39), hoje Tratado sobre o Funcionamento da União Europeia (artigo 45, porque a numeração foi alterada) ${ }^{37}$. Este último não exige o respeito ao princípio da livre circulação para os empregos da Administração Pública, que, em um primeiro momento, pareciam totalmente excluídos de seu campo de aplicação.

A função pública francesa repousa sobre um sistema dito de função pública fechada. $\mathrm{O}$ agente entra por concurso, que é a modalidade de acesso à função pública, é efetivado em um grau na carreira de um corpo de empregados.

Cada vez mais, como o conjunto do direito administrativo, o direito da função pública sofre influência de normas internacionais e europeias. O impacto mais importante é aquele do direito europeu, a convenção europeia ou o direito comunitário. Existe também certo número de convenções internacionais sob a égide da Organização Internacional do Trabalho que influi nas relações de trabalho dentro da função pública, notadamente em matéria de igualdade de sexo.

Em números, na França, a função pública civil do Estado emprega 1,9 milhão de agentes civis. $\mathrm{O}$ efetivo da função pública territorial gira em torno de 1,8 milhão de

\footnotetext{
${ }^{36}$ GONOD; MELLERAY; YOLKA, 2011, t. II, p. 369-373.

${ }^{37}$ Consultar <https://e-justice.europa.eu/fileDownload.do?id...>.
} 
agentes, sendo $19 \%$ não titulares. Quanto à função pública hospitalar, o efetivo está estimado em um milhão de agentes ${ }^{38}$.

Pode-se resumir a situação atual da França da seguinte maneira: as "três funções públicas" (função pública do Estado, territorial e hospitalar) permanecem distintas, na medida em que estão sujeitas a um estatuto geral separado e também são geridas por diferentes instituições e organismos.

\subsubsection{Direito português}

Marcello Caetano explica que, em Portugal, há agentes de direito e agentes de facto:

Quando o indivíduo é empregado mediante investidura regular torna-se agente de direito. Mas é frequente a Administração ser servida por indivíduos que foram irregularmente ou extraordinàriamente investidos nas funções e que, por isso, são meros agentes de facto. Para que se esteja perante um agente de facto, é preciso tratar-se de indivíduo aceite pacífica e pùblicamente como agente administrativo e que exerça funções no interesse geral. Os agentes de facto podem ser agentes necessários ou agentes putativos ${ }^{39}$.

É importante precisar que o funcionário de fato no Brasil é aquela pessoa que não é servidor, mas assume e exerce, de forma regular, a função, em situação normal ou excepcional. Poder-se-ia, então, pensar que o funcionário de fato (agente de fato) seria necessariamente o mesmo que o extranumerário ou temporário, no Brasil. Acidentalmente, no Brasil, um particular pode ser considerado funcionário de fato, em condições excepcionais ${ }^{40}$.

Com base na classificação de agentes de facto - agentes necessários e agentes putativos -, como exposto por Marcello Caetano, pode-se estabelecer uma certa semelhança ou aproximação entre os servidores temporários no Brasil e a subespécie portuguesa de agentes necessários, espécie de agentes de facto:

Denominamos agentes necessários os indivíduos que, em estado de necessidade e por imperativo do bem comum, se encarregam do exercício de funções públicas sem nelas terem sido investidos pelo processo regular. É o que se dá nos casos em que por efeito de guerra, revolta ou calamidade desaparecem ou não podem intervir os agentes de

\footnotetext{
${ }^{38}$ MELLERAY, Fabrice. Droit de la fonction publique. 3. éd. Paris: Economica, 2013 (ver p. 173, p. 189 e p. 202).

${ }^{39}$ CAETANO, Marcello. Manual de direito administrativo. 9. ed. Coimbra: Almedina, 1983, v. 2, p. 643644, grifos do autor.

${ }^{40}$ No Brasil, entende-se que o funcionário de fato não se confunde com o servidor temporário, conforme se poderá inferir das características do servidor temporário analisadas na subseção 2.6.3.
} 
direito, tornando-se indispensável que as pessoas com mais autoridade natural, com mais desembaraço ou com melhores condições assegurem, no interesse da comunidade, o funcionamento dos serviços ou o exercício dos poderes, independentemente do processo regular estabelecido por lei para a investidura nessas funções. Como a necessidade não conhece lei (necessitas non habet legem), enquanto durar a situação extraordinária o agente improvisado tem de ser considerado equiparado aos agentes de direito, contanto que as suas acções sejam exclusivamente inspiradas no interesse público e que as funções cessem logo que hajam cessado também as circunstâncias determinantes do seu exercício anormal ${ }^{41}$.

Em Portugal, apenas para fazer a diferença entre agentes necessários e agentes putativos, vale trazer os ensinamentos de Marcello Caetano:

Agentes putativos são os indivíduos que em circunstâncias normais exercem funções administrativas de maneira a serem reputados em geral como agentes regulares, apesar de não estarem vàlidamente providos nos respectivos cargos. $\mathrm{O}$ caso mais vulgar da situação de agente putativo é o que resulta do provimento em circunstâncias normais, por um acto jurídico ilegal, enquanto a invalidade não é declarada ou sanada (vício originário do provimento). O funcionário nomeado ilegalmente é um agente putativo, visto que a generalidade das pessoas não conhece (nem, conhecendo, poderia daí tirar efeitos práticos) o vício do acto de provimento e quando trata com ele no serviço reputa-o agente administrativo. Semelhante é a situação no caso de prolongação ilegal das funções públicas, para além da demissão ou da rescisão do contrato ou por virtude da perda de direitos políticos ou da nacionalidade portuguesa (vício superveniente ao provimento) ${ }^{42}$.

Em Portugal, falava-se ainda em quadros permanentes e quadros eventuais:

Os quadros estabelecidos por lei de harmonia com as necessidades normais ou constantes de um serviço administrativo chamam-se quadros permanentes. Teòricamente, nada obsta à existência de quadros eventuais. Pode, com efeito, ser necessário lançar mão de pessoal para determinados serviços temporários (um serviço de tempo de guerra, por exemplo) ou para fazer face a acréscimos transitórios de trabalho (a execução de um plano decenal de obras públicas, por exemplo) e então criam-se quadros eventuais, a preencher normalmente por pessoal contratado. E pode mesmo acontecer que sejam criados lugares permanentes nesse quadro eventual: o quadro passará não se sabe quando, o lugar pode ficar noutro quadro ${ }^{43}$.

João Caupers, ao tratar do quadro legal português mais recente, refere-se a uma distinção clássica, sugerida por ele sete anos antes, segundo a qual os recursos humanos da administração pública podem ser encarados de duas formas extremas:

a) no chamado modelo de carreira (também conhecido por "modelo francês"), as pessoas entram para o serviço da administração pública, usualmente através de um procedimento de concorrência (concurso), e aí

${ }^{41}$ CAETANO, 1983, v. 2, p. 644-645, grifos do autor.

${ }^{42}$ CAETANO, 1983, v. 2, p. 644-645, grifos do autor.

${ }^{43}$ CAETANO, 1983, v. 2, p. 653, grifos do autor. 
ficam, muitas vezes, a vida inteira, sendo regularmente promovidas a partir de uma posição de entrada até uma posição de topo na carreira que abraçaram;

b) no modelo oposto, dito de emprego (dito modelo "norte-americano"), a prestação de serviços à administração pública tende a ser considerada como um acidente de duração variável na vida do cidadão; a entrada para a administração pública faz-se por eleição ou escolha - mais ou menos condicionada, consoante os casos; o novo agente ao serviço da administração deixa temporariamente a sua actividade profissional e dedica alguns anos da sua vida ao serviço público; terminando este período regressa àquela actividade (é a chamada revolving door) ${ }^{44}$.

Assim, em Portugal, existiam dois regimes: um regime de direito público e outro de direito privado. A opção por um ou outro deveria obedecer a considerações relativas à natureza das necessidades que a atividade dos trabalhadores visava satisfazer: tratando-se de necessidades permanentes e próprias dos serviços, deveria aplicar-se o regime de direito público; caso as necessidades a satisfazer fossem conjunturais ou pontuais, a escolha deveria ser a oposta. A diferença fundamental residia na estabilidade do vínculo laboral, naturalmente maior no regime de direito público.

Em 2008, foram publicados três diplomas legais que arquitetaram o novo quadro legal dos recursos humanos da Administração Pública. Todos constam de leis aprovadas na Assembleia da República.

O primeiro foi a Lei n. ${ }^{\circ} 12-\mathrm{A} / 2008$, de 27 de fevereiro, que, nas palavras do legislador, "estabelece os regimes de vinculação, de carreiras e de remunerações dos trabalhadores que exercem funções públicas".

O segundo foi a Lei . $^{\text { }} 58 / 2008$, de 9 de setembro, que aprovou o Estatuto Disciplinar dos Trabalhadores que Exercem Funções Públicas.

O terceiro foi a Lei n. ${ }^{\circ}$ 59/2008, de 11 de setembro, que aprovou o Regime do Contrato de Trabalho em Funções Públicas.

Portugal sofreu muitas mudanças, e a realidade dos "funcionários públicos" foi bastante alterada; no lugar de funcionários públicos, fala-se em "trabalhadores que exercem funções públicas".

Alerta João Caupers que o abandono pela lei da expressão "funcionários" não representou, porém, a morte das dicotomias tradicionais inerentes: funcionários e agentes (não funcionários); trabalhadores em regime de direito público e trabalhadores em regime de direito privado. O que sucedeu é que elas foram redesenhadas. A distinção fulcral é

\footnotetext{
${ }^{44}$ CAUPERS, João. Introdução ao direito administrativo. 10 ed. Lisboa: Âncora, 2009, p. 176-177.
} 
agora entre os trabalhadores que exercem funções públicas em regime de nomeação ${ }^{45}$ e os trabalhadores que exercem funções públicas em regime de contrato (artigo 9..$^{\circ}$ da Lei n. ${ }^{\circ}$ 12-A/2008, de 27 de fevereiro). Este último constitui o regime regra, aplicável a todos os trabalhadores para os quais a lei não estabelece o regime de nomeação ${ }^{46}$.

O artigo 9. ${ }^{\circ}$ da Lei n. ${ }^{\circ}$ 12-A/2008 dispõe que a relação jurídica de emprego constitui-se por nomeação ou por contrato de trabalho em funções públicas. Mas o n. ${ }^{\circ} 4$ desse artigo acrescenta uma terceira modalidade - por comissão de serviço - e enumera as hipóteses para tal ${ }^{47}$. A comissão de serviço é, portanto, autonomizada, não mais dependendo da nomeação, uma vez que, no regime agora revogado pelo legislador, a comissão de serviço não passava de uma modalidade da nomeação ${ }^{48}$.

Quanto aos restantes trabalhadores (os que não devam ser nomeados e os trabalhadores cuja relação jurídica de emprego público não deva ser constituída por comissão de serviço), o artigo 20 da Lei n. ${ }^{\circ}$ 12-A/2008, de 27 de fevereiro, manda aplicarlhes o regime de contrato, distinguindo dois tipos: os contratos por tempo indeterminado e os contratos a termo resolutivo, certo ou incerto.

Por força do disposto no artigo 9. ${ }^{\circ}$ da Lei n. ${ }^{\circ}$ 12-A/2008, são, portanto, apresentadas as seguintes modalidades da relação jurídica de emprego: nomeação; contrato de trabalho em funções públicas, que pode assumir a natureza de contrato por tempo indeterminado ou contrato a termo resolutivo, certo ou incerto; comissão de serviço.

É importante trazer à colação o posicionamento de Paulo Veiga e Moura e Cátia Arrimar sobre contrato de trabalho em funções públicas:

Seguramente, e mesmo que se possa admitir que o contrato de trabalho em funções públicas representa um "tertium genus", caracterizado por um regime onde confluem normas de direito administrativo com normas de direito laboral, sempre pecaria o mesmo pela sua desconformidade com o texto fundamental, do que decorre, em nosso entender, que só em situações excepcionais, devidamente justificadas e alicerçadas na defesa de outros valores e interesses constitucionalmente protegidos, poderá o

\footnotetext{
${ }^{45}$ A Lei n. ${ }^{\text {12 }}$ 12-A/2008, de 27 de fevereiro, no artigo 10, determina a aplicação do regime de nomeação a certos grupos de trabalhadores: a) Forças Armadas; representação externa do Estado; informações de segurança; d) investigação criminal; e) segurança pública; f) inspeção. Trata-se de trabalhadores que se encontram no exercício de funções públicas de alguma forma relacionadas com o exercício da autoridade ou que envolvam o ius imperium.

${ }^{46}$ CAUPERS, 2009, p. 182-183.

47 “a) Do exercício de cargos não inseridos em carreiras, designadamente dos dirigentes; b) Da frequência de curso de formação específico ou da aquisição de certo grau acadêmico ou de certo título profissional antes do período experimental com que se inicia a nomeação ou o contrato, para o exercício de funções integrado em carreira, em ambos os casos por parte de quem seja sujeito de uma relação jurídica de emprego público por tempo indeterminado constituída previamente".

${ }^{48}$ MOURA, Paulo Veiga e; ARRIMAR, Cátia. Os novos regimes de vinculação, de carreiras e de remunerações dos trabalhadores da administração pública: comentário à Lei n. ${ }^{\circ}$ 12-A/2008, de 27 de Fevereiro. 2. ed. Coimbra: Coimbra Editora, 2010, p. 52.
} 
legislador ordinário afastar o regime-regra de direito público e substituílo por um regime assente no direito laboral ${ }^{49}$.

Ao analisar o contrato de trabalho em funções públicas, Paulo Veiga e Moura e Cátia Arrimar entendem que a regra vigente até 1 . $^{\circ}$ de janeiro de 2009 inverte-se, pois, se até aí, o meio normal de constituição das relações de emprego público era a nomeação, tendo o contrato administrativo uma feição marcadamente excepcional, a partir daquela data, a contratação dita administrativa passa a constituir o meio normal e majoritário de constituição das relações de emprego e a nomeação, a representar o meio excepcional.

Justamente nos contratos a termo resolutivo, previstos a partir do artigo 91 da Lei n. ${ }^{\circ}$ 59/2008, de 11 de setembro, encontra-se alguma semelhança com os servidores temporários constantes na legislação brasileira. Alguns pontos chamam a atenção.

O artigo 92 da Lei n. ${ }^{\circ}$ 59/2008, de 11 de setembro, deixa claro que o contrato a termo resolutivo "não se converte, em caso algum, em contrato por tempo indeterminado, caducando no termo do prazo máximo de duração previsto no Regime ou, tratando-se de contrato a termo incerto, quando deixe de se verificar a situação que justificou a sua celebração".

A legislação portuguesa alerta no artigo 92, n. ${ }^{\circ} 3$, da Lei n. ${ }^{\circ}$ 59/2008, de 11 de setembro:

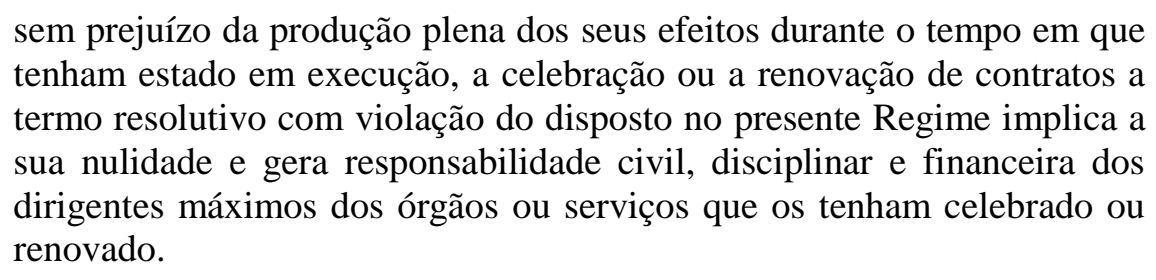

Um ponto interessante da legislação portuguesa que poderia ser incluído na legislação brasileira diz respeito ao fato de que, além da apuração da responsabilidade da pessoa que está trabalhando como servidor público temporário e comete faltas, poder-se-ia incluir também a responsabilidade civil, disciplinar e financeira da pessoa (dirigentes máximos dos órgãos ou serviços) que permitiu (celebrou) ou renovou a contratação (irregular). Além disso, ainda deve ser declarado nulo o contrato.

É importante conhecer os pressupostos do contrato a termo resolutivo na legislação portuguesa (artigo 93, da Lei n. ${ }^{\circ}$ 59/2008, de 11 de setembro):

1 - Nos contratos só pode ser aposto termo resolutivo nas seguintes situações fundamentadamente justificadas:

${ }^{49}$ MOURA; ARRIMAR, 2010, p. 50-51, grifo dos autores. 
a) Substituição directa ou indirecta de trabalhador ausente ou que, por qualquer razão, se encontre temporariamente impedido de prestar serviço; b) Substituição directa ou indirecta de trabalhador em relação ao qual esteja pendente em juízo acção de apreciação da licitude do despedimento;

c) Substituição directa ou indirecta de trabalhador em situação de licença sem remuneração

d) Substituição de trabalhador a tempo completo que passe a prestar trabalho a tempo parcial por período determinado;

e) Para assegurar necessidades urgentes de funcionamento das entidades empregadoras públicas;

f) Execução de tarefa ocasional ou serviço determinado precisamente definido e não duradouro;

g) Para o exercício de funções em estruturas temporárias das entidades empregadoras públicas;

h) Para fazer face ao aumento excepcional e temporário da actividade do órgão ou serviço;

i) Para o desenvolvimento de projectos não inseridos nas actividades normais dos órgãos ou serviços;

j) Quando a formação de grau acadêmico ou título profissional, dos trabalhadores no âmbito das entidades empregadoras públicas envolva a prestação de trabalho subordinado;

k) Quando se trate de órgãos ou serviços em regime de instalação.

Algumas situações poderiam enquadrar-se nas hipóteses do servidor público temporário, principalmente a da letra "e", ao mencionar necessidades urgentes. No n. ${ }^{\circ} 4$ do artigo 93 da Lei n. ${ }^{\circ}$ 59/2008, de 11 de setembro, há uma ressalva: "No caso da alínea 'e' do n. 1 , o contrato, incluindo as suas renovações, não pode ter duração superior a um ano".

O regime do Contrato de Trabalho em Funções Públicas aprovado pela Lei n. ${ }^{\circ}$ 59/2008, de 11 de setembro, foi ao encontro do que Vera Lúcia Santos Antunes chama "política de flexigurança", cuja implantação se propagou por toda a Europa ${ }^{50}$. Trata-se de uma política que busca conciliar a segurança com a flexibilidade, a necessidade de fazer face à exigência de mutações imprevistas. Justifica a necessidade de um regime legal flexível que se adapte a novos contextos, designadamente econômicos, capaz de superar as dificuldades do empregador num determinado momento.

Maria do Rosário Palma Ramalho conclui que, em Portugal, o regime atual dos trabalhadores públicos tende ora a afastar-se, ora a aproximar-se do regime laboral comum, de acordo com a conveniência de uma ou de outra tendência para a prossecução de objetivos determinados 51 .

\footnotetext{
50 ANTUNES, Vera Lúcia Santos. O contrato de trabalho na administração pública: evolução, reflexos e tendências para o emprego público. Coimbra: Coimbra Editora, 2010, p. 131.

${ }^{51}$ No âmbito do programa de ajuda financeira a Portugal, iniciado em 2011, e sobretudo por via do Orçamento Geral do Estado (OGE), têm sido introduzidas alterações no regime jurídico dos trabalhadores públicos (em regime de nomeação ou de contrato de trabalho em funções públicas), que, sob a justificação daquele Programa, afastam ainda mais o regime aplicável a esses trabalhadores do regime laboral comum.
} 
Diante da realidade portuguesa vivenciada, Maria do Rosário Palma Ramalho classifica a natureza jurídica da figura do vínculo de trabalho em funções públicas como controversa, e a recondução desse contrato a mais um contrato de trabalho especial parece comprometida, em favor da qualificação como uma figura jurídica híbrida, a meio caminho entre o contrato de trabalho comum e um vínculo de funcionalismo público tradicional.

Assim, observa-se uma tendência de aproximação entre os setores público e privado. Com essa tendência para o privado, o "servidor público" em Portugal tem sofrido cortes nos salários, nas pensões, perda de benefícios, enfim, a ideia é diminuir o Estado. $\mathrm{O}$ país está fazendo uma verdadeira alteração na sua legislação, muito por causa da situação de crise pela qual Portugal passa, bem como em função da União Europeia e suas diretivas, que devem ser transpostas para a legislação interna do país.

O direito da União Europeia projeta-se sobre a disciplina do emprego público por via do princípio da livre circulação de trabalhadores, conforme o artigo 45 do Tratado sobre o Funcionamento da União Europeia - que constitui uma das liberdades fundamentais da União Europeia - e das disposições que regulam ou que se associam a ela. Com muita propriedade Ana Fernanda Neves esclarece:

O princípio da livre circulação de trabalhadores veda por si a discriminação em razão da nacionalidade no acesso à generalidade dos empregos públicos, independentemente do tipo de vínculos laborais e do posicionamento desses empregos na carreira; apenas podem ser ressalvados, numa análise caso a caso, os empregos que envolvem o exercício ordinário e predominante de poderes de autoridade pública e que contendem com interesses vitais do Estado ou das coletividades locais ${ }^{52}$.

Segundo Ana Fernanda Neves, os nacionais dos Estados-Membros, assim como do Espaço Econômico Europeu têm o "direito individual à livre circulação e, em particular, à mobilidade profissional" (artigo 45 do Tratado sobre o Funcionamento da União Europeia). Mais que a igualdade de tratamento nacional, postula-se o afastamento de

Nessa linha, é de salientar a suspensão do direito desses trabalhadores aos subsídios de Natal e de férias no ano de 2012, entretanto considerada inconstitucional pelo Ac. n. ${ }^{\circ} 353 / 2012$, de 5 de julho, justamente com fundamento na quebra do princípio da igualdade de tratamento entre os trabalhadores públicos e os restantes cidadãos (incluindo os trabalhadores comuns), mas também medidas como o congelamento das progressões na carreira e a redução de suplementos remuneratórios. Nos termos das Leis do OGE, essas medidas prevalecem sobre os instrumentos de regulamentação coletiva de trabalho, em claro desvio às regras laborais gerais em matéria de articulação de fontes, e aplicam-se mesmo ao universo das empresas públicas, invertendo a tendência de privatização total do regime laboral vigente naquelas empresas, há muito consolidada (RAMALHO, Maria do Rosário Palma. Tratado de direito do trabalho. Parte II. Coimbra: Almedina, 2012, p. 347-348).

${ }^{52}$ NEVES, Ana Fernanda. O posto de trabalho e a mobilidade concorrencial como instrumentos jurídicos de tutela dos direitos do trabalhador público. In: In: FONSECA, Isabel Celeste M. (Coord.). Trabalho em funções públicas em tempos de crise: que direito(s)? Braga: Sindicato dos Trabalhadores em Funções Públicas e Sociais do Norte, 2013, p. 20. Atas das I Jornadas de Direito do Emprego Público. 
normas, decisões e práticas administrativas que obstem ao exercício do direito (como, por exemplo, que valorem a "nacionalidade" ou o local de aquisição das qualificações ou diplomas, ou desconsiderem experiência profissional em função do contexto institucional onde foi adquirida).

Pode-se dizer que, se não em todos os países, na maioria há necessidades de excepcional interesse público; certamente, existirá a figura do servidor público temporário ou uma figura com denominação diferente, mas com características assemelhadas. É uma realidade da qual não se pode fugir!

\subsection{CONCEITO DE AGENTES PÚBLICOS E CLASSIFICAÇÃO DO TEMPORÁRIO NO QUADRO DOS AGENTES PÚBLICOS}

\subsubsection{Conceito}

Para desenvolver suas funções (executiva, legislativa e judiciária), o Estado necessita de pessoas físicas. Tais pessoas são chamadas genericamente "agentes públicos".

A expressão "agentes públicos" é utilizada para englobar todos aqueles que prestam serviços ao Estado, de forma permanente ou transitória.

Os autores procuram definir agentes públicos das mais variadas formas. Serão aqui analisados alguns conceitos que servirão de base para entender quem é o "temporário".

Ensina Edmir Netto de Araújo:

Todo aquele que, de alguma forma, sob qualquer categoria ou título jurídico, desempenha função ou atribuição considerada pelo Poder Público como a si pertinente, seja em virtude de relação de trabalho (estatutário ou não), seja em razão de relação contratual, encargo público ou qualquer forma de função de natureza pública, será, enquanto a desempenhar, um agente público ${ }^{53}$.

Trata-se de um conceito bastante amplo. O autor já sinaliza que quem exerce função de natureza pública é um agente público, enquanto desempenhar a função em razão de uma relação contratual ou de uma relação de trabalho. Como se verá, o temporário exerce uma função, mediante um contrato por prazo determinado, sujeito a um regime administrativo, estando, portanto, enquadrado como agente público.

Como bem acentua José Cretella Júnior: "O funcionamento regular, contínuo e perfeito dos serviços públicos exige cada vez mais um número elevado de pessoas físicas,

${ }^{53}$ ARAÚJO, 2014, p. 288. 
uma classe bastante diferenciada de 'empregados', submetidos a um status especialíssimo e sob a dependência direta ou indireta de um superior hierárquico",54.

Observa-se, nas palavras de José Cretella Júnior, o cuidado com o princípio da continuidade do serviço público, com o princípio da eficiência, a preocupação com a necessidade de pessoas preparadas para desempenhar o serviço público, as quais são sujeitas a um regime especial, baseado em um poder hierárquico.

Assim, são agentes públicos para José Cretella Júnior:

todos os indivíduos que participam de maneira permanente, temporária ou acidental, da atividade do Estado, seja por atos jurídicos, seja por atos de ordem técnica e material. Esta expressão engloba não somente os indivíduos "engajados" pelo Estado ou pelos corpos locais em virtude de um título de direito público (título de nomeação), isto é, aqueles que são designados para executar funções pertencentes ao domínio do direito público, mas em geral todos aqueles que, sem distinção de função, são chamados, de um modo ou de outro, para colaborar no funcionamento dos serviços destes "corpos" públicos ${ }^{55}$.

O autor ainda acrescenta que podem ser considerados agentes públicos os indivíduos que participam de maneira temporária da atividade estatal, ou seja, todos os que, sem distinção de função, colaboram com o serviço público. Novamente, pode-se enquadrar o temporário como agente público.

Maria Sylvia Zanella Di Pietro aponta a necessidade de utilização de uma expressão de sentido mais amplo do que "servidor público" para designar as pessoas que exercem uma função pública, com ou sem vínculo empregatício. Para ela, agente público é "toda pessoa física que presta serviços ao Estado e às pessoas jurídicas da Administração Indireta" ${ }^{, 56}$.

A autora também utiliza um conceito bastante amplo, de forma a abranger todas as pessoas que prestam serviços ao Estado. Nesse conceito, o temporário também estaria incluído como agente público.

“Agente público", para Celso Antônio Bandeira de Mello é também uma expressão bastante ampla, em verdade, "a mais ampla que se pode conceber para designar genérica e indistintamente os sujeitos que servem ao Poder Público como instrumentos expressivos de sua vontade ou ação, ainda quando o façam apenas ocasional ou episodicamente" ${ }^{\text {, }}$. O referido autor afirma que "todos aqueles que prestam serviços ao Poder Público (União,

\footnotetext{
${ }^{54}$ CRETELLA JÚNIOR, José. Tratado de direito administrativo. 2. ed. Rio de Janeiro: Forense, 2005, v. 4, p. 61.

${ }^{55}$ CRETELLA JÚNIOR, 2005, v. 4, p. 63.

${ }^{56}$ DI PIETRO, Maria Sylvia Zanella. Direito administrativo. 26. ed. São Paulo: Atlas, 2013, p. 585.

${ }^{57}$ MELLO, Celso Antônio Bandeira de. Curso de direito administrativo. 30. ed. São Paulo: Malheiros, 2013, p. 248.
} 
Estados, Municípios e respectivas autarquias) ou realizam atividades da alçada deste podem ser designados agentes públicos". E resume: "quem quer que desempenhe funções de natureza pública é, enquanto as exercita, um agente público"58.

Portanto, Celso Antônio Bandeira de Mello adota o conceito bastante amplo de agente público, fazendo referência aos sujeitos que servem ao Poder Público de forma ocasional ou episodicamente. Poder-se-ia enquadrar o temporário como agente público tranquilamente nesse conceito.

Diogenes Gasparini define agente público como "todas as pessoas físicas que sob qualquer liame jurídico e algumas vezes sem ele prestam serviços à Administração Pública ou realizam atividades que estão sob sua responsabilidade" ${ }^{\text {59 }}$. Para o referido autor, são necessários dois requisitos para caracterizar o agente público: a) investidura em função pública; b) natureza pública da função.

Hely Lopes Meirelles ${ }^{60}$, Lucia Valle Figueiredo ${ }^{61}$ e Cármen Lúcia Antunes Rocha $^{62}$, em suas definições de agente público, mencionam pessoas físicas exercendo função temporária, transitória, o que abrange o servidor temporário.

A Lei de Improbidade Administrativa (Lei n. ${ }^{\circ}$ 8.429, de 2 de junho de 1992), em seu artigo $2 .^{\circ}$, conceitua agente público da seguinte forma:

Reputa-se agente público, para os efeitos desta lei, todo aquele que exerce, ainda que transitoriamente ou sem remuneração, por eleição, nomeação, designação, contratação ou qualquer outra forma de investidura ou vínculo, mandato, cargo, emprego ou função nas entidades mencionadas no artigo anterior.

A legislação específica (artigo 327 do Código Penal) considera "funcionário público, para efeitos penais, quem, embora transitoriamente ou sem remuneração, exerce cargo, emprego ou função pública”. Ao funcionário é equiparado, nos termos da mesma lei, "quem exerce cargo, emprego ou função em entidade paraestatal, e quem trabalha para empresa prestadora de serviço contratada ou conveniada para a execução de atividade típica da Administração Pública" (§ 1.º).

\footnotetext{
${ }^{58}$ MELLO, 1987, p. 3.

${ }^{59}$ GASPARINI, Diogenes. Direito administrativo. 17. ed. São Paulo: Saraiva, 2012, p. 191.

${ }^{60} \mathrm{Na}$ visão de Hely Lopes Meirelles, agentes públicos "são todas as pessoas físicas incumbidas, definitiva ou transitoriamente, do exercício de alguma função estatal" (MEIRELLES, Hely Lopes. Direito administrativo brasileiro. 38. ed. São Paulo: Malheiros, 2012, p. 76).

${ }^{61}$ Lúcia Valle Figueiredo conceitua agentes públicos como "todos aqueles investidos em funções públicas, quer permanente, quer temporariamente" (FIGUEIREDO, Lúcia Valle. Curso de direito administrativo. 9. ed. São Paulo: Malheiros, 2008, p. 598).

62 Ensina Cármen Lúcia Antunes Rocha que agente público é a "pessoa física que, vinculando-se juridicamente a uma pessoa pública, dispõe de competência legalmente estabelecida para o desempenho de função estatal em caráter permanente ou transitório" (ROCHA, 1999. p. 59).
} 
É importante ressaltar que todas as funções estatais (função legislativa, judiciária e executiva) são exercidas por agentes públicos, não se restringindo à função administrativa.

$\mathrm{Na}$ variedade de conceitos de agente público, pode-se notar a presença comum de alguns aspectos: pessoa física, exercendo função estatal (legislativa, administrativa ou judiciária) de forma permanente, definitiva, temporária, transitória ou acidental.

Partindo-se do pressuposto de que o temporário é um agente público, pois é uma pessoa física que exerce função estatal de forma temporária, transitória, como estaria classificado pela doutrina?

\subsubsection{Classificação}

De início, é importante ressaltar que "as classificações não são verdadeiras nem falsas, são úteis ou inúteis" ${ }^{\prime 63}$.

Oswaldo Aranha Bandeira de Mello classificou os agentes públicos segundo o critério da relação jurídica do agente com o Estado, distinguindo duas espécies: de representação ou de emprego. Assim, há os agentes políticos e os agentes empregados ${ }^{64}$.

Também Edmir Netto de Araújo posiciona os agentes públicos em três grandes grupos: os agentes políticos (integrantes da alta esfera da Administração, eleitos ou nomeados em comissão, em termos transitórios), os servidores públicos (prestam serviços de natureza profissional, não eventual, com o vínculo de dependência com o Estado) e os particulares em colaboração com a Administração (relação de caráter contratual, como a empreitada, a concessão, ou em regime de permissão ou autorização). Ressalta o autor que a expressão "agente público" é de grande amplitude e aplicável a um sem-número de hipóteses de caracterização do Estado como Administração ${ }^{65}$.

Após referir-se ao fato de que o maior contingente de agentes públicos é o de servidores públicos, Edmir Netto de Araújo esclarece:

Assim, também entendemos que na Administração direta e autárquica continuam existindo servidores funcionários públicos (que, na Administração federal se denominam servidores públicos civis), ocupantes de cargos, de regime estatutário; empregados públicos celetistas, ocupantes de empregos públicos (na Administração estadual

\footnotetext{
${ }^{63}$ GORDILlO, Agustín. Princípios gerais de direito público. Tradução de Marco Aurélio Greco. São Paulo: Revista dos Tribunais, 1977, p. 11.

${ }^{64}$ MELLO, Oswaldo Aranha Bandeira de. Teoria dos servidores públicos. Revista de Direito Público, São Paulo, v. 1, n. 1, jul./set. 1967, p. 44. Ver também: MELLO, Oswaldo Aranha Bandeira de. Relação jurídica entre o Estado e os seus servidores. São Paulo: Prefeitura do Município de São Paulo, 1945, p. 15.

${ }^{65}$ ARAÚJO, 2014, p. 289-290.
} 
paulista, de 'função-atividade') e servidores públicos não efetivos, de regime estatutário mas ocupantes de "funções" (ou "funções-atividade") como os temporários ou os remanescentes dos antigos extranumerários, todos abrigados na noção genérica de servidor público. $\mathrm{O}$ sentido estrito de servidor, repetimos, só compreenderia, segundo a $\mathrm{CF}$, os titulares de cargos públicos, admitidos por concurso público ${ }^{66}$.

Na classificação proposta por Edmir Netto de Araújo, estão incluídos, no sentido amplo de servidor público, os empregados públicos, de regime contratual trabalhista.

Do ponto de vista de Edmir Netto de Araújo, os temporários são classificados como agentes públicos, da espécie servidores públicos não efetivos, de regime estatutário, mas ocupantes de "funções" ou "funções-atividades".

Adotando a classificação de Oswaldo Aranha Bandeira de Mello, Edmir Netto de Araújo também entende que a relação dos agentes com o Estado pode ser de "representação" ou de "emprego".

A partir das classificações apresentadas, quais agentes públicos poderiam ser sujeitos ativos de transgressões disciplinares, puras ou qualificadas, ou seja, enquadradas no regime jurídico de ilícito administrativo? Quem responde a essa pergunta é Edmir Netto de Araújo:

todos os que desempenham atividades administrativas no serviço público: os servidores (funcionários públicos, servidores celetistas contratados por autarquias ou fundações públicas, "ferroviários", "precários", extranumerários e outros regimes especiais ainda existentes), certos empregados públicos de entidades descentralizadas prestadoras de serviços públicos, e ainda certos agentes políticos, estes últimos embora submetidos (geralmente) a regimes especiais de responsabilidade ${ }^{67}$.

Segundo Celso Antônio Bandeira de Mello ${ }^{68}$, que se baseia na sistematização de Oswaldo Aranha Bandeira de Mello, com algumas adaptações, em razão do atual texto constitucional, os agentes públicos podem ser divididos em três grandes grupos:

a) agentes políticos;

b) servidores estatais, abrangendo:

b.1 servidores públicos;

b.1.1 servidores titulares de cargos públicos na Administração Direta, nas autarquias e fundações de direito público da União, dos estados, do Distrito

\footnotetext{
${ }^{66}$ ARAÚJO, 2014, p. 292-293, grifos do autor.

${ }^{67}$ ARAÚJO, Edmir Netto de. O ilícito administrativo e seu processo. São Paulo: Revista dos Tribunais, 1994, p. 45.

${ }^{68}$ MELLO, 2013, p. 251-258.
} 
Federal e dos municípios, assim como no Poder Judiciário e na esfera administrativa do Legislativo;

b.1.2 servidores empregados das pessoas suprarreferidas, abrangendo os servidores que se encontrem sob vínculo empregatício por uma das seguintes razões:

b.1.2.1 haverem sido admitidos sob vínculo de emprego para funções materiais subalternas;

b.1.2.2 serem remanescentes do regime anterior, no qual se admitia amplamente o regime de emprego;

\section{b.1.2.3 terem sido contratados, nos termos do artigo 37, IX, da Constituição,} sob o vínculo trabalhista, para atender a uma necessidade temporária de excepcional interesse público (Lei n. ${ }^{\circ} 8.745$, de 9 de dezembro de 1993);

b.2 servidores das pessoas governamentais de direito privado;

c) particulares em atuação colaboradora com o Poder Público.

Hely Lopes Meirelles propõe uma classificação de agentes públicos composta de cinco espécies: agentes políticos, agentes administrativos, agentes honoríficos, agentes delegados e agentes credenciados, que se subdividem em subespécies ${ }^{69}$.

A classificação apresentada, como o próprio autor reconhece, não corresponde à dos demais autores pátrios, como a adotada por Oswaldo Aranha Bandeira de Mello e por Celso Antônio Bandeira de Mello.

Hely Lopes Meirelles dissente da classificação de Oswaldo Aranha Bandeira de Mello e de Celso Antônio Bandeira de Mello, por entender que os servidores públicos não constituem uma espécie do gênero agente público, mas, apenas, uma subespécie da espécie agente administrativo. Segundo sua classificação, é essa última espécie que deriva imediatamente do gênero agente público, que, depois, ao lado de outras espécies, reparte-se em servidores públicos. Diverge, também, o mesmo autor da inclusão dos agentes honoríficos na mesma categoria ou espécie dos agentes delegados, sob a denominação comum de particulares em colaboração com o Poder Público, por considerar que são por demais marcantes as peculiaridades de cada espécie.

Na classificação de agentes públicos proposta por Cármen Lúcia Antunes Rocha, não estão incluídos, entre os agentes públicos, os particulares que diz agirem com o Estado

\footnotetext{
${ }^{69}$ MEIRELLES, 2012, p. 76-77.
} 
e não como o Estado. Segundo essa autora, no sistema constitucional brasileiro, a expressão "agente público" não inclui os particulares: mesmo aqueles que atuam em regime de colaboração com o Poder Público, permanecem naquela condição jurídica ${ }^{70}$.

Assim, Cármen Lúcia Antunes Rocha, pelo critério objetivo, classifica o gênero agente público em: agentes políticos, membros de poder, servidores públicos - os quais são objeto de subclassificação -, militares e agentes civis especiais (nominados, às vezes, pela doutrina de agentes honoríficos).

De acordo com a classificação de Maria Sylvia Zanella Di Pietro, com as alterações introduzidas pela Emenda Constitucional n. ${ }^{\circ}$ 18/98, os agentes públicos classificam-se em quatro grandes grupos: agentes políticos, servidores públicos, militares e particulares em colaboração com a Administração ${ }^{71}$.

A referida autora esclarece que os militares, até a Emenda Constitucional n. ${ }^{\circ}$ 18/98, eram tratados como "servidores militares"; a partir dessa Emenda, exclui-se a denominação “servidores”. Consequentemente, diz Maria Sylvia Zanella Di Pietro, foi necessário incluir a categoria dos militares na classificação de agentes públicos. O que diferencia os servidores civis e os militares é o regime jurídico parcialmente diverso.

A categoria de militares abrange os membros da Polícia Militar e do Corpo de Bombeiros dos estados, do Distrito Federal e dos territórios (artigo 42 da Constituição Federal) e os membros das Forças Armadas - Marinha, Exército e Aeronáutica (artigo 142 da Constituição Federal).

Explica Maria Sylvia Zanella Di Pietro quem faz parte de cada uma das categorias de agentes públicos, conforme sua classificação.

A noção de agente político "liga-se, indissociavelmente, à de governo e à de função política, a primeira dando ideia de órgão (aspecto subjetivo) e, a segunda, de atividade (aspecto objetivo)"72. São agentes políticos, porque desempenham "típicas atividades de governo e exercem mandato para o qual são eleitos, apenas os chefes dos Poderes Executivos federal, estadual e municipal, os ministros e secretários de Estado, além de senadores, deputados e vereadores" ${ }^{73}$.

Os servidores públicos, em sentido amplo, são "as pessoas físicas que prestam serviços ao Estado e às entidades da Administração Indireta, com vínculo empregatício e

\footnotetext{
${ }^{70}$ ROCHA, 1999, p. 60-62.

${ }^{71}$ DI PIETRO, 2013, p. 585-588.

${ }^{72}$ DI PIETRO, 2013, p. 586, grifos da autora.

${ }^{73}$ A forma de investidura é a eleição, salvo para ministros e secretários, que são de livre escolha do Chefe do Executivo e providos em cargos públicos, mediante nomeação (DI PIETRO, 2013, p. 587, grifos da autora).
} 
mediante remuneração paga pelos cofres públicos" ${ }^{\text {,74 }}$. A referida autora inclui no grupo de servidores públicos:

1. os servidores estatutários, sujeitos ao regime estatutário e ocupantes de cargos públicos; 2. os empregados públicos, contratados sob o regime da legislação trabalhista e ocupantes de emprego público; 3. os servidores temporários, contratados por tempo determinado para atender a uma necessidade temporária de excepcional interesse público (art. 37, IX, da Constituição) - exercem funçãa, sem estarem vinculados a cargo ou emprego público ${ }^{75}$.

Quanto aos particulares em colaboração com o Poder Público, para Maria Sylvia Zanella Di Pietro ${ }^{76}$, nessa categoria entram as pessoas físicas que prestam serviços ao Estado, sem vínculo empregatício, com ou sem remuneração. São eles:

a) delegação do Poder Público ${ }^{77}$;

b) mediante requisição, nomeação ou designação ${ }^{78}$;

c) como gestores de negócio ${ }^{79}$.

Após analisar a classificação dos agentes públicos adotadas por diversos autores, filiamo-nos à corrente que classifica os temporários como espécie de servidores públicos do gênero agentes públicos, pelas características apresentadas, pela natureza jurídica do vínculo e pelo quadro geral da legislação. Assim, defender-se-á aqui, como base para o desenvolvimento do raciocínio, que o temporário é um agente público da espécie servidor público. Durante o curso do trabalho, empregar-se-á a denominação "servidor público temporário".

\subsection{CARGO, EMPREGO OU FUNÇÃO PÚBLICA?}

Em vários dispositivos, a Constituição Federal faz referência a cargos, empregos e funções. Será necessário esclarecer o significado de cada um desses elementos para

\footnotetext{
${ }^{74}$ DI PIETRO, 2013, p. 587.

75 DI PIETRO, 2013, p. 587-588, grifos da autora.

${ }^{76}$ DI PIETRO, 2013, p. 592-593.

77 Aqueles que, por delegação do Poder Público, exercem uma função pública, em seu próprio nome, sem vínculo empregatício, porém sob a fiscalização do Poder Público e são remunerados não pelos cofres públicos, mas pelos terceiros usuários do serviço, como os empregados das empresas concessionárias e permissionárias de serviços públicos, os que exercem serviços notariais e de registro (art. 236 da Constituição), os leiloeiros, tradutores e intérpretes públicos.

${ }^{78}$ Aqueles que são requisitados, nomeados ou designados para o exercício de funções públicas relevantes, também não têm vínculo empregatício e, em geral, não recebem remuneração, como os jurados, os convocados para prestação de serviço militar ou eleitoral, os comissários de menores, os integrantes de comissões, grupos de trabalho etc.

79 Aqueles que, como gestores de negócio, assumem, espontaneamente, determinada função pública em momento de emergência, como epidemias, incêndios, enchentes etc.
} 
determinar em qual dessas três espécies (cargo, emprego ou função) o servidor temporário enquadra-se.

No artigo $3 .^{\circ}$ da Lei n. ${ }^{\circ} 8.112 / 90$, cargo público é definido como "o conjunto de atribuições e responsabilidades previstas na estrutura organizacional, que devem ser cometidas a um servidor".

Pode-se imaginar uma cômoda de guardar roupas com suas gavetas. A estrutura da cômoda corresponde à estrutura organizacional da Administração Pública, as gavetas da cômoda são os cargos compostos de atribuições e responsabilidades, funções específicas e remuneração fixadas em lei.

Celso Antônio Bandeira de Mello conceitua cargo público da seguinte forma:

é a denominação dada à mais simples unidade de poderes e deveres estatais a serem expressos por um agente. É, pois, um complexo (ou um ponto, ou um termo), unitário e indivisível de competências, criado por lei, com número certo e designação própria concernente a funções da organização central do Estado, suas autarquias e fundações públicas. Podem-se definir os cargos como as mais simples e indivisíveis unidades abstratas criadas por lei, com denominação própria e número certo, que sintetizam um centro de competências públicas da alçada das pessoas jurídicas de direito público, a serem exercidas por um agente ${ }^{80}$.

Em seguida, ensina que os cargos públicos podem ser classificados da seguinte forma: de provimento em comissão, de provimento efetivo, de provimento vitalício.

Para Regis Fernandes de Oliveira, cargo político é o vocacionado a provimento por eleição ou vitalício (a expressão política, aqui, está tomada no sentido daquele que detém o exercício do Poder); cargo em comissão é o destinado a provimento precário e exonerável a qualquer momento; cargo efetivo é aquele que somente pode ser ocupado por intermédio de concurso público. Não é o servidor que é efetivo; é o cargo que se destina a provimento permanente $^{81}$.

Na visão de José dos Santos Carvalho Filho, cargo público "é o lugar dentro da organização funcional da Administração Direta e de suas autarquias e fundações públicas que, ocupado por servidor público, tem funções específicas e remuneração fixadas em lei ou diploma a ela equivalente" ${ }^{\prime 82}$.

Celso Antônio Bandeira de Mello assim define empregos públicos:

\footnotetext{
${ }^{80}$ MELLO, Celso Antônio Bandeira de. Regime constitucional dos servidores da administração direta e indireta. 2. ed. São Paulo: Revista dos Tribunais, 1991, p. 28-30.

${ }^{81}$ OLIVEIRA, Regis Fernandes de. Servidores públicos. 2. ed. São Paulo: Malheiros, 2008, p. 15.

${ }^{82}$ CARVALHO FILHO, José dos Santos. Manual de direito administrativo. 25. ed. São Paulo: Atlas, 2012a, p. 604.
} 
núcleos de encargos de trabalho permanentes a ser preenchidos por agentes contratados para desempenhá-los, sob relação trabalhista, como aliás, prevê a Lei 9.962, de 22.2.2000. Quando se trate de empregos permanentes na Administração direta ou em autarquia, só podem ser criados por lei, como resulta do art. $61, \S 1$ o $^{\mathrm{o}}, \mathrm{II}, \mathrm{a}^{,}{ }^{83}$.

A expressão "emprego público" é utilizada para designar a relação funcional trabalhista, assim como a expressão "empregado público" é usada como sinônima de servidor público trabalhista. É importante lembrar que o servidor trabalhista tem função (no sentido de tarefa, atividade), mas não ocupa cargo. O servidor estatutário tem o cargo que ocupa e exerce as funções atribuídas ao cargo ${ }^{84}$.

De forma bastante clara, Edmir Netto de Araújo sintetiza:

o emprego público é ocupado por um agente público (o empregado público, também considerado em algumas Administrações servidor público), mas sob regime jurídico de direito privado (trabalhista). Mas tal regime não é integralmente privado, pois seus integrantes contam com prerrogativas e sujeições que não se aplicam aos empregados das empresas particulares, especialmente no caso de entidades prestadoras de serviços públicos ${ }^{85}$.

Como exemplo, ao emprego público aplicam-se a vedação constitucional de acumulação remunerada de cargos, empregos ou funções, a equiparação a servidores funcionários públicos para fins criminais, a exigência de concurso público para admissão (artigo 37, II, da Constituição Federal) - exceto para o pessoal dirigente e em comissão -, a exigência de lei para a criação, a transformação e a extinção dos empregos na Administração Federal (artigo 48, X, da Constituição Federal).

Assim, quem ocupa emprego público tem um vínculo contratual, sob a regência da Consolidação das Leis do Trabalho. Já o ocupante de cargo público tem um vínculo estatutário, regido pelo Estatuto dos Funcionários Públicos; no caso da União, a Lei n. ${ }^{\circ}$ 8.112/90 instituiu o regime jurídico único.

Apesar da existência de diferentes significados para a palavra "função", a noção de função que se estudará diz respeito à função pública.

E como bem situou o problema, argumenta Edmir Netto de Araújo:

$\mathrm{Na}$ verdade, queremos focalizar função pública como aquilo que o indivíduo que a detém ocupa (como os cargos públicos e os empregos públicos), na estrutura administrativa do Estado, inclusive de suas entidades. A noção de função pública como algo (local) "ocupado" por um servidor corresponde, mais ou menos, à ideia de "posto de trabalho", que, na Administração estadual paulista, foi mencionada pela Lei

\footnotetext{
${ }^{83}$ MELLO, 2013, p. 260-261.

${ }^{84}$ CARVALHO FILHO, 2012a, p. 606.

${ }^{85}$ ARAÚJO, 2014, p. 293-294, grifos do autor.
} 
Complementar n. ${ }^{\circ}$ 180, de 12 de maio de 1978. Não obstante, sempre se ligou à atividade desempenhada, como conjunto de atribuições e responsabilidades cometidas a servidor: a cada função preenchida (art. 40), deve corresponder um posto de trabalho ${ }^{86}$.

Edmir Netto de Araújo ressalta que, em obras mais antigas ${ }^{87}$, "funções" referiam-se a atividades não permanentes, esporádicas, resolvidas em atribuições não erigidas em cargos públicos (destinados a atividades permanentes). Além desse caso, em que as funções eram desempenhadas por extranumerários mensalistas, consideravam-se também as funções gratificadas (chefia, assessoramento etc.), desempenhadas cumulativamente por quem já ocupava algum cargo público.

Afirma ainda Edmir Netto de Araújo que o sentido de atividade perdura tanto para cargos como para empregos, como atribuições, poderes, direitos, deveres, ínsitos a ambos. Mas a função era utilizada nos ordenamentos anteriores como forma de burlar a exigência de lei formal para a criação de cargos e empregos; servidores eram efetivados nessas “funções", sem que houvesse previsão legal e concurso público ${ }^{88}$.

Com a Constituição de 1988, limitou-se a possibilidade de existência dos quadros paralelos, de funções não criadas por lei, somente aos casos do regime especial de servidores admitidos "para atender a necessidade temporária de excepcional interesse público" (artigo 37, IX), sempre com contratação por tempo determinado, que atualmente, na esfera federal, é regida pela Lei n. ${ }^{\circ}$ 8.745, de 9 de dezembro de 1993. Além disso, existem as funções permanentes de chefia, direção e assessoramento, exercidas em confiança (artigo 37, V), para as quais não tenha sido criado por lei o respectivo cargo, sem a exigência de concurso público ${ }^{89}$.

Edmir Netto de Araújo, ao referir-se à função no sentido tradicional de atividade, que abrange também as "funções" desempenhadas pelos ocupantes de cargos e empregos públicos, revela que, no Estado de São Paulo, continua existindo a função-atividade, usada para designar (de acordo com a Lei Complementar n. ${ }^{\circ} 180 / 78$, artigo 5. ${ }^{\circ}$, I, III e V) o conjunto de competências, atribuições e responsabilidades cometidos aos temporários da

\footnotetext{
${ }^{86}$ ARAÚJO, 2014, p. 295, grifos do autor.

${ }^{87}$ Edmir Netto de Araújo cita Mário Masagão (Curso de direito administrativo. 3 ed. São Paulo: Max Limonad, 1960, p. 206 e p. 209).

${ }^{88}$ ARAÚJO, 2014, p. 297.

${ }^{89} \mathrm{Na}$ administração estadual de São Paulo, nem sequer se aprovou a lei do "regime único", continua sendo utilizada, para o regime especial, a Lei n. ${ }^{\circ}$ 500/74. Recentemente, pela Lei Complementar n. ${ }^{\circ} 1.093$, de 16 de julho de 2009, instituiu-se a possibilidade de contratação de agentes públicos por tempo determinado, o que é também um regime especial.
} 
Lei n. ${ }^{\circ}$ 500/74, aos eventuais remanescentes de extranumerários, aos servidores celetistas autárquicos, ou seja, àqueles que não ocupam cargos públicos ${ }^{90}$.

Celso Antônio Bandeira de Mello apresenta a seguinte definição de funções públicas:

são plexos unitários de atribuições, criados por lei, correspondentes a encargos de direção, chefia ou assessoramento, a serem exercidas por titular de cargo efetivo da confiança da autoridade que as preenche (art. 37, V, da CF). Assemelham-se, quanto à natureza das atribuições e quanto à confiança que caracteriza seu preenchimento, aos cargos em comissão. Contudo, não se quis prevê-las como tais, possivelmente para evitar que pudessem ser preenchidas por alguém estranho à carreira, já que em cargos em comissão podem ser prepostas pessoas alheias ao serviço público, ressalvado um percentual deles, reservado aos servidores de carreira, cujo mínimo será fixado por lei ${ }^{91}$.

Nota-se no conceito acima que não há referência ao sentido de "função" exercida pelo servidor público temporário, constante do artigo 37, IX, da Constituição Federal.

Regis Fernandes de Oliveira define função pública da seguinte maneira:

É o conjunto de atribuições estipuladas para o desempenho de atividade pública. Todo cargo tem funções que lhe são fixadas (há exemplo único no país do "cargo" de Vice-Prefeito, que não tem função, por ser ele titular de mandato e não ocupante de cargo). $\mathrm{O}$ ocupante de função não tem, necessariamente, cargo. A este são atribuídas funções ${ }^{92}$.

Depreende-se que todo cargo possui funções, mas o ocupante de função pode ou não possuir cargo. Como exemplo, cite-se o servidor público temporário, que não ocupa cargo, desempenha função.

No ensinamento de Maria Sylvia Zanella Di Pietro, na Constituição atual, quando se fala em função, devem-se considerar dois tipos de situações:

1. a função exercida por servidores contratados temporariamente com base no artigo 37, IX, para a qual não se exige, necessariamente, concurso público, porque, às vezes, a própria urgência da contratação é incompatível com a demora do procedimento; a Lei $n$. $^{\circ} 8.112 / 90$ definia, no artigo $233, \S 3 .^{\circ}$, as hipóteses em que o concurso era dispensado; esse dispositivo foi revogado pela Lei $\mathrm{n}^{\circ}$ 8.745, de 9-12-93, que agora disciplina a matéria, com as alterações posteriores. 2. as funções de natureza permanente, correspondendo a chefia, direção, assessoramento ou outro tipo de atividade para a qual o legislador não crie o cargo respectivo; em geral, são funções de confiança, de livre provimento e exoneração, a elas se refere o artigo $37, \mathrm{~V},[\ldots]^{93}$.

\footnotetext{
${ }^{90}$ ARAÚJO, 2014, p. 297.

${ }^{91}$ MELLO, 2013, p. 260, grifos do autor.

${ }^{92}$ OLIVEIRA, 2008, p. 30.

${ }^{93}$ DI PIETRO, 2013, p. 595.
} 
É importante ter em mente que os servidores temporários exercem função, com fulcro no artigo 37, IX, da Constituição Federal. Assim, o artigo 37, V, da Constituição Federal trata das funções, permanentes, de livre escolha e exoneração; o artigo 37, IX, da Constituição Federal dispõe sobre as funções temporárias. Observa-se que os dois incisos do artigo 37 (V e IX) referem-se a situações diferentes, destinadas a suprir necessidades temporárias e excepcionais, geralmente urgentes, incompatíveis com a demora de realização de concurso; destinam-se, em última análise, a suprir uma insuficiência de pessoal, o que explica a dispensa de seleção pública.

Em conclusão, entende-se que o servidor público temporário exerce função, ou seja, um conjunto de atribuições previstas para o desenvolvimento de uma atividade pública. É preciso deixar claro que os servidores públicos temporários não ocupam cargo ou emprego, não se exigindo, necessariamente, concurso público, pois a excepcionalidade e a urgência da contratação são incompatíveis com a demora da realização do concurso público. Há certos casos, no entanto, em que são realizadas provas de seleção (Lei n. ${ }^{\circ}$ 500/74, de São Paulo).

\subsection{REGIME JURÍDICO FUNCIONAL: CONCEITUAÇÃO DOGMÁTICA E SUA INTEGRAÇÃO AO REGIME CONSTITUCIONAL BRASILEIRO DA ADMINISTRAÇÃO PÚBLICA}

\subsubsection{Considerações iniciais sobre o regime jurídico}

Regime jurídico é um conjunto de direitos e deveres, proibições, condições de trabalho, normas disciplinares, vencimentos, vantagens a serem observadas pelo servidor público.

A Constituição Federal de 1988 delineou as normas fundamentais para a instituição do regime jurídico dos servidores públicos das entidades públicas.

Pode-se dizer que regime jurídico é o conjunto de direitos e deveres a que o agente público está submetido. É a sua lei maior, com prerrogativas e sujeições próprias. Observase a existência do regime estatutário, do regime trabalhista e de um regime especial, que conteria características dos dois regimes anteriormente citados.

Com muita propriedade Edmir Netto de Araújo ressalta:

Os regimes jurídicos de pessoal para os agentes públicos são basicamente: o estatutário, de direito público, no qual o Estado se coloca em posição de supremacia, podendo alterar certas condições de trabalho unilateralmente (o que reforça a suposição antiga de que 
"estatutário" e "contrato de função pública" seriam meros jogos de palavras); e contratual, de direito privado, pelo qual a posição do Estado não detém tal supremacia, embora sofra algumas derrogações em sua pureza em virtude da pessoa do empregador e dos serviços públicos que o órgão ou entidade prestam ${ }^{94}$.

Embora haja grande número de regimes jurídicos especiais e extravagantes nesse campo, tais como "precários", "temporários", "ferroviários", "Lei 500", na verdade dois são os regimes de pessoal civil mais utilizados: o estatutário e o da CLT, que coexistem na Administração, muitas vezes no mesmo órgão e na mesma repartição, até na mesma sala ${ }^{95}$.

O regime jurídico pode variar no tempo e no espaço, de país a país, evoluindo de acordo com as transformações morais, econômicas e sociais ${ }^{96}$.

Carlos Borges de Castro, ao referir-se à noção de regime jurídico, expõe:

Regime jurídico de determinado agente que desenvolve funções subordinadas é o conjunto de direitos e deveres a que esse agente se submete ao concretizar-se o vínculo jurídico que o liga à entidade subordinante. O vinculum iuris é ou eminentemente estatutário, ou predominantemente trabalhista, havendo, em alguns casos, uma posição híbrida: confronte-se a situação do pessoal admitido em caráter temporário no funcionalismo do Estado de São Paulo, submetido a regramentos trabalhista-estatutários.

Da natureza do liame decorre o respectivo regime jurídico, regime esse que se localiza na Constituição, nas leis, nos regulamentos das empresas e nos estatutos dos funcionários, que, mais de perto, regem a relação funcional $^{97}$.

Para José dos Santos Carvalho Filho, do regime jurídico, originam-se diversos direitos e deveres para os servidores públicos:

$\mathrm{Na}$ verdade, são muito variados os fatos funcionais que os envolvem durante o tempo em que exercem a função pública. Por essa razão, o órgão administrativo precisa ter o prontuário referente a cada servidor, de modo a permitir que as autoridades competentes consultem qualquer dado de sua vida funcional. As anotações funcionais do servidor usualmente constam de atos administrativos inseridos em seu prontuário, constituindo o que se costuma denominar de apostilas. $\mathrm{O}$ fato funcional averbado denomina-se de apostilamento. Como as apostilas têm a presunção de legitimidade, direitos e deveres nelas averbados desafiam regular cumprimento; somente em decorrência de seu desfazimento, por anulação ou revogação, é que ficam destituídas de eficácia ${ }^{98}$.

${ }_{94}^{94}$ ARAÚJO, 2014, p. 292, grifos do autor.

${ }^{95}$ ARAÚJO, 2014, p. 978.

${ }^{96}$ CAVALCANTI, Themístocles Brandão. O funcionário público e o seu regime jurídico. 2. ed. Rio de Janeiro: Freitas Bastos, 1946, p. 76.

${ }^{97}$ CASTRO, Carlos Borges de. Regime jurídico da CLT no funcionalismo. São Paulo: Saraiva, 1981, p. 1, grifos do autor.

${ }_{98}$ CARVALHO FILHO, 2012a, p. 592-593, grifos do autor. 
Diante disso, antes de estudar o regime jurídico disciplinar dos servidores temporários, é preciso conhecer o regime jurídico dos servidores temporários. Não há uma unanimidade entre os doutrinadores: regime público especial, regime estatutário, regime celetista, contrato administrativo inominado submetido ao regime das aquisições públicas (Lei das Licitações n. ${ }^{\circ}$ 8.666/93) ou ainda contrato civil de prestação de serviços? Serão examinados os principais regimes jurídicos existentes na legislação pátria para, em seguida, definir o regime que se enquadraria melhor na contratação temporária do artigo 37, IX, da Constituição Federal.

\subsubsection{Regime estatutário}

Estatutário é o regime jurídico que representa um conjunto de normas às quais o servidor público está submetido, ou seja, um conjunto de direitos, vantagens, deveres, proibições e responsabilidades.

Como características do regime estatutário, Carlos Borges de Castro aponta:

O regime jurídico estatutário é caracterizado pela elasticidade das condições em que a função pública é exercida e é suscetível de modificações unilaterais pelo Poder Público, no diretivo de os desígnios administrativos atingirem sua finalidade. Em suma: o pessoal estatutário - instrumento da realização dos fins administrativos - pode ter seu regime jurídico alterado a todo tempo e em quaisquer circunstâncias, sendo, contudo, respeitados os direitos adquiridos e mantidas as garantias asseguradas pela Constituição ${ }^{99}$.

A relação entre o servidor estatutário e a Administração Pública é de natureza institucional, pois a manifestação de vontade limita-se ao nascimento do vínculo, e a sua continuidade não decorre da vontade das partes, decorre da lei ${ }^{100}$.

Na lição de José dos Santos Carvalho Filho, regime estatutário é o conjunto de regras que regulam a relação jurídica funcional entre o servidor público estatutário e o Estado. Esse conjunto normativo encontra-se no estatuto funcional da pessoa federativa. As regras estatutárias básicas devem estar contidas em lei; há outras regras mais de caráter organizacional, que podem estar previstas em atos administrativos, como decretos, portarias, circulares etc. Carvalho Filho afirma: "para o regime estatutário, há um regime

\footnotetext{
${ }^{99}$ CASTRO, 1981, p. 45-46.

${ }^{100}$ CAVALCANTE, Jouberto de Quadros Pessoa; JORGE NETO, Francisco Ferreira. O empregado público. São Paulo: LTR, 2002, p. 54.
} 
constitucional superior, um regime legal contendo a disciplina básica sobre a matéria e um regime administrativo de caráter organizacional"101.

José dos Santos Carvalho Filho identifica duas características no regime estatutário: a pluralidade normativa e a natureza não contratual da relação jurídica estatutária ${ }^{102}$.

A pluralidade indica que os estatutos funcionais são múltiplos; cada pessoa da federação, ao adotar o regime estatutário, precisa ter a sua lei estatutária.

A outra característica refere-se à natureza da relação jurídica estatutária. Tal relação não tem natureza contratual, ou seja, inexiste contrato entre o Poder Público e o servidor estatutário. Nesse tipo de relação jurídica não contratual, a conjugação de vontades que conduz à execução da função pública leva em conta outros fatores tipicamente de direito público, como o provimento do cargo, a nomeação, a posse e outros do gênero.

Bem argumenta Diogo de Figueiredo Moreira Neto:

Pelo sistema institucional estabelece-se um vínculo legal, cria-se um status para o servidor público, que implica direitos e deveres, tornandose de certa forma, aquele titular de um cargo público, uma parte da Administração Pública, a sua expressão física, através do qual realiza-se a ação executiva do Governo ${ }^{103}$.

Alvacir Correa dos Santos conclui quanto ao regime estatutário:

Enfim, a ilação principal é a de que inexiste acordo de vontades no que tange ao conteúdo do vínculo que une o ocupante de cargo público ao Estado. A nomeação daquele se dá por ato unilateral, inserindo-o sob um regime jurídico preestabelecido.

O regime estatutário, por abarcar determinados princípios e institutos (tais como o princípio do mérito, o primado do interesse público sobre a autonomia da vontade, a garantia da estabilidade contra o abuso do poder político) sem paralelo em outros regimes de pessoal, representa uma conquista da sociedade na busca da democratização do poder.

O referido regime possibilita a valorização do princípio da legalidade no âmbito da Administração Pública, uma vez que, pelo fato de sua existência depender de lei, o controle interno ou externo de sua observância passa a ser uma possibilidade concreta ${ }^{104}$.

Quando houver algum litígio entre o Estado e os servidores estatutários, compete à Justiça Comum dirimi-lo, seja a Justiça Federal para os servidores federais, seja a Justiça Estadual no caso de servidores estaduais e municipais.

\footnotetext{
${ }^{101}$ CARVALHO FILHO, 2012a, p. 593.

102 CARVALHO FILHO, 2012a, p. 593.

103 MOREIRA NETO, Diogo de Figueiredo. Regime jurídico único dos servidores públicos na Constituição de 1988. Rio de Janeiro: Lumen Juris, 1990, p. 34, grifos do autor.

104 SANTOS, Alvacir Correa dos. Contratação temporária na Administração Pública. Curitiba: Gênesis, 1996 , p. 65.
} 
No âmbito federal, tem vigência a Lei n. ${ }^{\circ}$ 8.112/90, que dispõe sobre o regime jurídico dos servidores públicos civis da União, das autarquias e das fundações públicas federais. O Título I trata das disposições preliminares; o Título II, de provimento, vacância, remoção, redistribuição e substituição; o Título III, dos direitos e vantagens; o Título IV dispõe sobre o regime disciplinar, que estabelece os deveres, as proibições, as disposições sobre acumulação de cargos, as responsabilidades e as penalidades.

Dessa forma, o regime estatutário caracteriza-se por ser o regime institucional, legal, no qual as regras já estão predefinidas, não havendo espaço para a autonomia da vontade, ou seja, a vontade que deve prevalecer é a vontade da lei. Tal regime aplica-se aos servidores permanentes da Administração Pública.

\subsubsection{Regime trabalhista}

Regime trabalhista é o conjunto de normas que regulam a relação jurídica entre o Estado e seus empregados públicos. Assim, o regime aplicável é o da Consolidação das Leis do Trabalho (CLT), aprovada pelo Decreto-Lei n. ${ }^{\circ} 5.452$, de $1 .^{\circ}$ de maio de 1943.

Carlos Borges de Castro afirma que, a partir do instante em que se socorre da Consolidação das Leis do Trabalho, o Estado (em sentido lato) é equiparado ao empregador, definido pelo artigo $2 .^{\circ}$ da mesma CLT, pois que assalaria o pessoal que admite na condição de empregado (definido pelo artigo $3 .^{\circ}$ ), o que caracteriza a relação empregatícia $^{105}$.

José dos Santos Carvalho Filho identifica duas características do regime trabalhista: o princípio da unicidade normativa e a natureza contratual da relação jurídica estatutária ${ }^{106}$.

Para respeitar o princípio da unicidade normativa, o conjunto das normas reguladoras encontra-se em um único diploma legal, que é a Consolidação das Leis do Trabalho. Isso significa que todas as pessoas federativas que adotem esse regime deverão guiar-se pelas regras desse único diploma. José dos Santos Carvalho Filho ressalta que, sendo o empregador o Estado, algumas normas de direito público incidem na relação trabalhista. Tais normas, porém, não podem desfigurar o regime básico da Consolidação das Leis do Trabalho, que é aquele que deve ser observado e que tem natureza contratual.

Quanto à segunda característica, ao contrário do que ocorre no regime estatutário, no regime trabalhista, a relação jurídica é de natureza contratual. Logo, o Estado e seu

\footnotetext{
${ }^{105}$ CASTRO, 1981, p. 120.

${ }^{106}$ CARVALHO FILHO, 2012a, p. 595.
} 
servidor trabalhista celebram efetivamente um contrato de trabalho nos mesmos moldes adotados para a disciplina das relações gerais entre capital e trabalho ${ }^{107}$.

É importante ressaltar que, mesmo nas contratações pelo regime trabalhista, impõem-se à relação jurídica de trabalho normas de Direito Público, como, por exemplo, a exigência de aprovação em concurso público, a vedação de acumulação de cargos e empregos, a remuneração etc. ${ }^{108}$.

Carlos Borges de Castro aponta diferenças acentuadas entre o contratado pelos órgãos públicos (“celetista público”) e aquele que é admitido pela empresa particular ("celetista privado"), todas elas provocadas pelo fato de a Administração agir em função do interesse coletivo, buscando o atendimento das necessidades públicas que sobrelevam os interesses individuais ${ }^{109}$.

A contratação de pessoal que, sob o regime da Consolidação das Leis do Trabalho, servirá nos quadros administrativos depende de aprovação prévia em processo seletivo. Até aí, nada difere da empresa moderna, que, também, promove o recrutamento e a seleção na busca do trabalhador que reúna qualidades para o exercício de certo emprego ${ }^{110}$.

Segundo o artigo 442 da Consolidação das Leis do Trabalho (CLT), o contrato individual de trabalho "é o acordo tácito ou expresso, correspondente à relação de emprego". O artigo 443 da Consolidação das Leis do Trabalho dispõe que o ajuste "poderá ser acordado tácita ou expressamente, verbalmente ou por escrito e por prazo determinado ou indeterminado".

Ressalta Carlos Borges de Castro:

Bem por isso, a faculdade do Estado em determinar o regime jurídico de natureza estatutária mantida com o funcionário público (que, já vimos à saciedade, proporciona a modificação das condições originalmente estabelecidas, sem ofensa a qualquer direito subjetivo) não prevalece em relação ao celetista. O Estado deve cumprir as cláusulas ajustadas, não

\footnotetext{
107 José dos Santos Carvalho Filho chama o empregado público "servidor trabalhista".

${ }^{108}$ CAVALCANTE; JORGE NETO, 2002, p. 56.

${ }^{109}$ CASTRO, 1981, p. 120.

110 Quatro peculiaridades da Administração Pública são citadas. A primeira diz respeito aos recursos orçamentários disponíveis, visto que, antes de qualquer providência administrativa, impõe-se verificar a existência de verba apropriada para a admissão. Aliás, a realização da despesa pública só pode ocorrer após a indicação dos recursos orçamentários correspondentes, consoante explícito mandamento constitucional. A segunda é a seleção pública: em nome da democratização de oportunidades, é indispensável a realização de processo seletivo de provas ou de provas e títulos para que se concretize a admissão. A terceira é a publicidade. Com efeito, a publicidade de atos administrativos é procedimento dominante e, até mesmo, imperativo na Administração Pública. Dessa maneira, a seleção deve ser antecedida de ampla divulgação, seja pela afixação de edital em recinto acessível ao público, seja por publicações em jornais oficiais, ou não. A quarta é a obediência à classificação: a admissão será feita com rigorosa observância da ordem de classificação dos candidatos. Como se vê, essa diferença é a mais importante em relação à empresa privada, que, por não estar obrigada a admitir aquele que obteve as maiores notas, tem a faculdade de aquilatar as qualidades pessoais do trabalhador por meio de entrevista (CASTRO, 1981, p. 121-122).
} 
lhe sendo lícito impor nem mesmo condições mais favoráveis; estas, mesmo que identificadas em lei extravagante, só terão eficácia se transplantadas para o contrato de trabalho, o que, em última análise, significa o mútuo consentimento a que se refere o art. 468 da CLT. Tal comando, em síntese, denota que nas leis do trabalho o traço comum é o caráter bilateral da relação de emprego ${ }^{111}$.

Outrossim, convém lembrar que o contrato escrito não dispensa a Carteira de Trabalho e Previdência Social ${ }^{112}$.

A Lei n. ${ }^{\circ}$ 9.962, de 22 de fevereiro de 2000, passou a disciplinar, no âmbito da União, o chamado regime de emprego público. Prevê a admissão de pessoal como empregado público e a transformação dos atuais cargos em empregos na forma da legislação especial, com vedação expressa apenas para os cargos de provimento em comissão.

O artigo $3 .^{\circ}$ da Lei n..$^{\circ}$ 9.962/2000 trata da extinção do contrato de trabalho por ato unilateral da Administração Pública nos seguintes casos: prática de falta grave (artigo 482 da Consolidação das Leis do Trabalho), acumulação ilegal de cargos, empregos ou funções públicas, necessidade de redução de quadro de pessoal por excesso de despesas e, por fim, insuficiência de desempenho, apurada em procedimento administrativo do qual caiba pelo menos um recurso.

José dos Santos Carvalho Filho, ao comentar a Lei n. ${ }^{\circ}$ 9.962/2000, observa:

${ }^{111}$ CASTRO, 1981, p. 123, grifos do autor.

${ }^{112}$ A Carteira de Trabalho e Previdência Social é documento probante da existência do ajuste expresso (CLT, art. 446). Subsidiariamente é documento de identificação do trabalhador, equivalente a qualquer outro documento de identidade. É obrigatória para o exercício de qualquer emprego (CLT, art. 13, caput). Nela são registrados os acidentes do trabalho sofridos (CLT, art. 30). Presta-se a outros assentamentos, como férias gozadas, alterações salariais, inscrições no PIS/PASEP (CASTRO, 1981. p. 123). Em síntese, Carlos Borges de Castro aponta as seguintes diferenças entre o celetista público e o celetista privado: "O contratado sob o regime das leis trabalhistas não é, de modo absoluto, celetista ou funcionário: é um 'fronteiriço'. Não é empregado 'puro' porque as derrogações entre celetista público e celetista privado são notórias. Há direitos 'exclusivos' do trabalhador comum: reajustes semestrais; liberdade para ter mais de um emprego, para fazer greve (exceto em atividades essenciais na lei); para sindicalizar-se etc. Também não é funcionário 'puro', seja em razão do regime jurídico a que está submetido, seja em razão de prerrogativas próprias dos estatutários. Por exemplo: não faz jus aos adicionais por tempo de serviço denominados quarta e sexta partes; pode ter seu contrato de trabalho rescindido a qualquer tempo; não tem aposentadoria com proventos integrais etc. É um tertium genus que se aproxima ora do celetista privado, ora do funcionário público. Goza de direitos desconhecidos da pessoa física a que se refere o art. $3 .^{\circ}$ da CLT, como, apenas para exemplificar, o direito subjetivo à admissão, durante o prazo de validade do processo seletivo em que foi habilitado; conta, para determinados fins, o tempo de serviço, no momento em que passa a ser estatutário; se servidor paulista, aufere das vantagens outorgadas pela Lei Complementar n. ${ }^{\circ}$ 180/78. Usufrui de regalias que ao funcionário são interditas. A principal: inalterabilidade de seu contrato de trabalho, exceto se com a alteração concordar e, assim mesmo, se desse consentimento não resultarem prejuízos (CLT, art. 468). Repise-se que a relação jurídica entre o Estado e o funcionário é administrativa e, por consequência, direitos e deveres são estabelecidos unilateralmente pelo Poder Público. Mas não é só. A irredutibilidade de salário, a incorporação de gratificações concedidas com habitualidade, a impossibilidade de sobrestamento de férias, por necessidade de serviço, o abono de permanência em serviço, a indenização por ruptura contratual sem justa causa são direitos que o celetista público conhece e que o funcionário público ignora" (CASTRO, 1981. p. 174). 
A lei é federal e, portanto, incide apenas no âmbito da administração federal direta, autárquica e fundacional, estando excluídas as empresas públicas e as sociedades de economia mista. Prevê que o regime de emprego público será regido pela CLT (Decreto-Lei n. ${ }^{\circ}$ 5.452/1943) e pela legislação trabalhista correlata, considerando-as aplicáveis naquilo que a lei não dispuser em contrário (art. 1. ${ }^{\circ}$ ). Dessa ressalva, infere-se que a Lei n. $^{\circ} 9.962$ é a legislação básica e que as demais haverão de ter caráter subsidiário: só prevalecem se forem compatíveis com aquela ${ }^{113}$.

Luísa Cristina Pinto e Netto é defensora da contratualização da função pública:

Conclui-se, assim, pela compatibilidade e melhor adequação do modelo contratual com o arcabouço constitucional gizado para a função pública, compatibilidade esta instrumentalizada pela conjugação de disciplina legal e consensual, garantindo-se, por um lado, as exigências impostas pelo interesse público e, por outro, a necessidade de saturar a relação de função pública de elementos consensuais consentâneos com o Estado Democrático de Direito ${ }^{114}$.

Dessa forma, é importante ressaltar que a competência para a resolução de litígios entre o Estado e empregados públicos é da Justiça do Trabalho.

\subsubsection{Regime especial}

O artigo 106 da Constituição de 1967 (com redação dada pela Emenda Constitucional n. ${ }^{\circ}$ 1/1969) continha o seguinte texto: “O regime jurídico dos servidores admitidos em serviços de caráter temporário ou contratados para funções de natureza técnica especializada será estabelecido em lei especial".

$\mathrm{Na}$ época, doutrina e jurisprudência defendiam que o regime especial possuía natureza administrativa e não celetista.

A pergunta que se faz é a seguinte: sob o manto da Constituição Federal de 1988, com seu artigo 37, IX, ainda se pode falar em regime especial?

Defende-se que, para o servidor temporário, haverá um regime público especial, híbrido, submetido aos princípios de direito público, em razão das peculiaridades próprias de tal categoria de servidores públicos. Melhor explicando, não se aplica o regime estatuário geral integralmente, mas haveria um regime próprio, de natureza administrativa, que guarda semelhanças com o regime estatutário, como há para o Ministério Público, a Magistratura.

${ }^{113}$ CARVALHO FILHO, 2012a, p. 596, grifo do autor.

${ }^{114}$ NETTO, Luísa Cristina Pinto e. A contratualização da função pública. Belo Horizonte: Del Rey, 2005, p. 307. 
Poder-se-ia questionar se, pela dicção do artigo 37, IX, da Constituição Federal, o dispositivo constitucional refere-se expressamente ao termo "contratação". Entende-se que poderia ter sido usada outra palavra. Isso não significa que deve ser aplicado integralmente o regime celetista aos servidores temporários, pois nada impede - por ser um regime híbrido - que seja feito um contrato contendo dispositivos do regime estatutário.

Vale ressaltar que, por contratação, o constituinte só autorizou o contrato administrativo e o contrato de trabalho. Entende-se que se trata de um contrato administrativo de pessoal regido por leis administrativas.

Observa-se que o dispositivo 106 da Constituição de 1967 (com redação dada pela Emenda Constitucional n. ${ }^{\circ}$ 1/1969) e o artigo 37, IX, da Constituição de 1988 são diferentes. Mas, embora a Constituição atual não contenha a expressão "regime especial", defende-se que a contratação temporária é de natureza administrativa, submetida a um regime especial, próprio, mais próximo do regime estatutário. Entende-se ser esta a posição que mais se adapta à figura estudada.

Afastando a aplicação do regime trabalhista nos casos de contratação por tempo determinado, Alvacir Correa dos Santos defende fortes, sólidos, válidos e convincentes argumentos que merecem ser apresentados ${ }^{115}$ :

Em primeiro lugar, Alvacir Correa dos Santos evidencia que o ente político, ao editar a lei prevista no artigo 37, IX, da Constituição Federal, estará, por intermédio dela, disciplinando os casos de contratação por tempo determinado, não havendo necessidade de socorrer-se do regime da Consolidação das Leis do Trabalho. E a aplicação do regime da Consolidação das Leis do Trabalho aos servidores temporários implicaria considerá-los empregados públicos, mas o artigo 37, II, da Constituição Federal exige concurso público para a investidura em cargo ou emprego público; pela excepcionalidade da situação do artigo 37, IX, não se pode falar em concurso público de provas ou de provas e títulos como requisito prévio para a contratação.

Outra razão seria que, ao submeter a contratação temporária ao regime da Consolidação das Leis do Trabalho, deita-se os olhos sobre as disposições do artigo 443 e seguintes desse estatuto. Pela análise desses dispositivos, percebe-se que o contrato por prazo determinado é considerado exceção, já que a regra é o contrato por prazo indeterminado. Ao enumerar as hipóteses contidas no artigo 443, § 2. , da Consolidação das Leis do Trabalho, Alvacir Correa dos Santos cita o seguinte exemplo:

${ }^{115}$ SANTOS, 1996, p. 68-73. 
Ora, como, então, é possível, imaginar a hipótese de um Município qualquer estabelecer os casos (especialíssimos) de contratação previstos no inciso IX, submetendo essa contratação ao regime da CLT, sabendo-se que a CLT não contém previsão nesse sentido? Teria ganho esse Município autorização constitucional para ampliar as hipóteses de exceção de contratação a termo, previstas pela CLT? A resposta deve ser negativa, conforme o que preceitua o artigo 22 , I, da $\mathrm{CF}^{116}$.

Dentre os argumentos citados pelo referido autor para rejeitar-se a aplicação do regime da Consolidação das Leis do Trabalho aos servidores temporários, destacam-se:

1) O Supremo Tribunal Federal (STF) assentou a natureza administrativa da contratação. Trata-se de um forte argumento, visto que a matéria já foi analisada pelo Egrégio Supremo Tribunal Federal, a quem cabe dizer a última palavra em Direito.

2) Sempre se aspirou a uma maior autonomia política e administrativa para os Estados, Distrito Federal e municípios (artigo 18 da Constituição Federal). Ao adotar-se o regime da CLT para os casos de contratação temporária, essas entidades políticas estarão, implicitamente, renunciando às competências institucionais. E mais, pelo artigo 39 da Lei Maior, têm os referidos entes competência para instituir o regime jurídico único para os servidores permanentes. Por que também não a teriam para instituir outro regime para os servidores temporários?

3) Estando a Administração Pública sujeita aos princípios da legalidade e da finalidade, isto é, adstrita ao fiel cumprimento da lei e propugnando pela satisfação do bem comum, cabe indagar se o interesse público pode submeter-se às exigências da legislação trabalhista. Em outras palavras, o interesse superior da coletividade deve ficar à mercê das normas celetistas, criadas para defender o empregado do mau patrão? Seria possível conceber o Estado, cuja atividade é necessariamente voltada para o bem comum, como um mau patrão? Vê-se, objetivamente, que os interesses que compete ao Poder Público defender não se coadunam com a legislação trabalhista.

4) Pelo regime celetista, veda-se a alteração contratual danosa ao empregado (conforme artigo 468 da CLT). Assim, é possível que, mesmo diante de interesses públicos de relevo, determinado ato possa não ser praticado por estar o servidor sob o amparo da legislação consolidada. Em suma, ante os severos mandamentos da CLT, a Administração acaba por perder a necessária flexibilidade no trato com o seu corpo funcional.

5) Se se afirma que o regime deve ser o celetista, então há que admitir tratar-se de regime de emprego público, e não de função pública. Todavia, o artigo $61, \S 11^{\circ}$, II, a, da

${ }^{116}$ SANTOS, 1996, p. 70. 
Constituição diz que a criação de emprego público depende de lei. Ora, não se pode supor que a lei do inciso IX deva indicar empregos a que se possa chegar sem concurso, por intermédio de contratados temporários. Não haveria como arrolar ou qualificar esses empregos, pois o objetivo do constituinte foi estabelecer mecanismos para o enfrentamento de situações anômalas, de exceção, portanto, de repercussões imprevisíveis. Por isso, não há como antecipar quais as funções e quantas demandariam provisório preenchimento a fim de atender àquelas situações. É importante ressaltar que se defende que os servidores temporários exercem função.

6) Se a lei mencionada no inciso IX estabelecer tão somente os casos, mandando aplicar a CLT, estará aberta a porta ao administrador público para a livre manipulação dos prazos das contratações (pode estabelecer, por exemplo, que todos os casos de necessidade temporária arrolados na lei sejam contratados pelo prazo de dois anos, pois esse é o limite do artigo 445 da CLT). Isso não se coaduna com a regra de exceção do inciso IX, muito menos com os princípios da moralidade e da finalidade da Administração Pública. Não há como deixar que uma situação de excepcional interesse público seja submetida à CLT. Trata-se de um caso especial, que deve ser submetido ao crivo de regras específicas, predominantemente sob o regime estatutário, atentas ao interesse público e aos demais princípios que regem a Administração Pública.

7) Pode acontecer, também, que, durante a contratação pelo regime celetista, seja ultrapassado o limite de dois anos previsto no artigo 445 da CLT. Então se pergunta: seria possível admitir que o contrato passou a prazo indeterminado? Um reconhecimento da espécie perante a Justiça do Trabalho (justiça protetora do trabalhador por excelência) não faria com que, por vias transversas, fosse criada uma espécie de cargo público (suponha-se que na entidade pública vigore o regime estatutário para a totalidade dos servidores), em total afronta aos princípios da legalidade (criação de cargo ou emprego público somente mediante lei), da moralidade, da impessoalidade, da publicidade e da isonomia? Afinal, a admissão do servidor estaria ocorrendo sem a prévia aprovação em concurso público, em total desrespeito aos demais servidores que ingressaram por intermédio desse certame.

8) Se se afirmar, por exemplo, que determinado município, além dos casos de contratação temporária, pode estabelecer outros prazos não previstos pela CLT, por que não asseverar também que esse município estará adaptando a CLT para atender às suas conveniências? E essa adaptação não seria o mesmo que instituir um regime?

9) O regime celetista dificulta a observância do artigo 169 da Constituição e seu parágrafo único (limites para o atendimento de despesas de pessoal, concessão de 
vantagens ou aumento de remuneração, admissão de pessoal, na Administração Pública), pois é entendimento assente na Justiça do Trabalho que o ente público se despe de suas prerrogativas de poder público quando contrata pessoal pelo regime da CLT.

10) Além disso, o artigo 7. ${ }^{\circ}$, “c”, da CLT dispõe: "Os preceitos constantes da presente Consolidação, salvo quando for, em cada caso, expressamente determinado em contrário, não se aplicam: [...] c) aos funcionários públicos da União, dos Estados e dos Municípios e aos respectivos extranumerários em serviço nas próprias repartições”.

Assim, mais compatível com as características do servidor público temporário seria a existência de um regime jurídico especial, próprio, semelhante ao regime estatuário, de natureza administrativa.

Raphael Diógenes Serafim Vieira muito bem analisa a questão da aplicação de um regime especial aos servidores temporários, defendendo e justificando a sua posição no sentido de que a natureza do regime regulatório dos servidores públicos temporários é, seguramente, pública, o que afasta qualquer intuito leviano de aproximá-lo do regime celetista e do conjunto de regras, institutos e princípios relativos ao Direito do Trabalho:

Como elemento público, identifica-se a natureza da contratação, porquanto, seguramente, sofre o influxo do conjunto normativo de direito administrativo, bem como dos institutos e princípios hermenêuticos desse ramo: o direito público. Por sua vez, o elemento especial evidencia a forma singular do provimento do servidor público temporário, que, diferentemente dos servidores públicos estatutários - cuja investidura dáse por meio de ato unilateral - tem a solenização do seu ingresso aos quadros administrativos instrumentalizada por ato bilateral: o contrato administrativo. $\mathrm{O}$ designativo especial serve ainda para delimitar o elemento público, pois as contratações temporárias não sofrem a incidência de todas as normas de direito pré-definidas no estatuto público, aplicáveis aos servidores estatutários, mas tão-somente daqueles que guardem compatibilidade implícita ou previsão expressa na própria lei, como sugere o art. 11, da Lei n. ${ }^{\circ} 8.745 / 93^{117}$.

O referido autor vai mais longe e continua o seu raciocínio, esclarecendo ainda:

Destarte, a expressão regime público especial tenciona aproximar tal regime da natureza pública respeitante aos servidores públicos estatutários, ao passo que a afasta definitivamente do regime celetista. Todavia, ao mesmo tempo que o vernáculo público induz a confundir-se o regime em comento com o regime público estatutário, intervém o designativo especial cuja função delimitadora é distingui-los, esclarecendo que os servidores públicos temporários sujeitam-se a regime público com conotação específico, fato que lhe promove contornos hermenêuticos próprios e postura autônoma no interior do ordenamento jurídico positivo. [...] Diante disso, considerando como um contrato cujo regime enseja uma perspectiva especial, embora sujeito ao influxo hermenêutico do Direito Público, não se amolda integralmente ao

${ }^{117}$ VIEIRA, 2007, p. 37, grifos do autor. 
regulamento pré-definido no Estatuto do Servidor Público, com o qual espelha situações que poderão ser complementares e não excludentes. Note-se que a Lei n..$^{\circ}$ 8.745/93 optou por ampliar, aos contratos temporários, os direitos relativos aos servidores estatutários, em vez de distender as prerrogativas relacionadas aos celetistas $[\ldots]^{118}$.

É exatamente nesse sentido que se defende um regime público especial, mais próximo do regime estatutário, ou seja, um regime que aplique o que for compatível com a situação transitória de excepcional interesse público, visto que são casos de interesse público, não tendo qualquer conotação privada.

Dentre os autores que defendem um regime especial a ser aplicado aos servidores temporários, destacam-se: Maria Sylvia Zanella Di Pietro ${ }^{119}$, José dos Santos Carvalho Filho $^{120}$, Ivan Barbosa Rigolin ${ }^{121}$, Arion Sayão Romita ${ }^{122}$, Sergio Luiz Barbosa Neves ${ }^{123}$, Odete Medauar $^{124}$ e Frederico Jorge Gouveia de Melo ${ }^{125}$.

\footnotetext{
${ }^{118}$ VIEIRA, 2007, p. 38-39, grifos do autor.
}

119 "Os servidores temporários, contratados por tempo determinado para atender a necessidade temporária de excepcional interesse público (art. 37, IX, da Constituição), exercem função, sem estarem vinculados a cargo ou emprego público [...] são contratados para exercer funções em caráter temporário, mediante regime jurídico especial a ser disciplinado em lei de cada unidade da federação. Eles substituem os servidores a que fazia referência o artigo 106 da Constituição de 1967 (com redação dada pela Emenda Constitucional n. ${ }^{\circ}$ 1/1969), que previa, também, um regime especial para duas hipóteses: servidores admitidos em serviços de caráter temporário ou contratados para funções de natureza técnica especializada" (DI PIETRO, 2013, p. 588, grifos da autora).

${ }^{120}$ Para José dos Santos Carvalho Filho, "o regime especial visa a disciplinar uma categoria específica de servidores que são os servidores temporários" (CARVALHO FILHO, 2012a, p. 598).

121 "Trata-se, dessa forma, de contratações de pessoal que nada têm com a CLT, nem com o regime estatutário propriamente - ainda que as normas regedoras daqueles contratos lembrem de perto as constantes dos estatutos de funcionários, sem com elas se confundirem em hipótese alguma. Estamos diante, é fácil perceber, de autênticos contratos administrativos de pessoal, regidos por leis administrativas locais, e submetidos, portanto, ao disciplinamento e aos princípios próprios do direito público, inatingíveis quer pela lei trabalhista, quer pela lei civil, quer pela lei previdenciária nacional comum (porque ademais, entre outras previsões, estão disciplinadas, nas 'leis especiais', as questões e os direitos previdenciários dos servidores abrangidos” (RIGOLIN, Ivan Barbosa. O servidor público na Constituição de 1988. São Paulo: Saraiva, 1989, p. 90, grifos do autor).

122 "No regime constitucional anterior a 5 de outubro de 1988, três eram os regimes jurídicos dos servidores públicos civis: 1 - o estatutário [...]; 2 - o trabalhista [...]; 3 - o especial, próprio dos admitidos em serviços de caráter temporário ou contratados para funções de natureza técnica especializada - Emenda Constitucional n. ${ }^{\circ}$, artigo 106. A Constituição de 5 de outubro de 1988 conserva esses regimes, porém, com nova feição" (ROMITA, Arion Sayão. Regime jurídico dos servidores públicos civis: aspectos trabalhistas e previdenciários. São Paulo: LTR, 1992, p. 7).

123 "Este regime, outrora previsto no art. 106 da Constituição anterior, está previsto pela atual no inciso IX do art. 37, com uma pequena diferença. Não é mais possível, como era, contratar servidores sob este regime para exercer funções de natureza técnica especializada. Atualmente só é possível a contratação de pessoal por tempo determinado para atender a necessidade temporária de excepcional interesse público [...] há que ser editada uma lei pelo ente interessado. Este regime, apesar de distinto do estatutário, tem que ser de natureza administrativa, sendo também distinto do celetista" (NEVES, Sergio Luiz Barbosa. Regime jurídico único e os servidores púbicos. Rio de Janeiro: Lumen Juris, 1991, p. 28).

${ }^{124}$ A autora entende que os servidores contratados pelo artigo 37, IX, da Constituição Federal podem-se considerar sob regime especial: "Segundo fixar a lei, o contrato poderá ser regido pela CLT ou a própria lei estabelecerá o regime jurídico, podendo até determinar a aplicação, a tais servidores, de preceitos do Estatuto correspondente. Em nível federal, a Lei n. ${ }^{\circ} 8.745$, de 09.12.1993, com alterações posteriores, dispõe sobre essa contratação, inclusive determinando, no art. 11, a aplicação, a tais contratados, de vários preceitos do 
Fabrício Motta lembra que a natureza jurídica do vínculo é de função pública e, sobre o regime jurídico dos contratos temporários, afirma:

A lei de cada entidade federativa deverá optar pelo regime trabalhista ou pelo vínculo estatutário. Se o regime trabalhista for escolhido, o seguimento da CLT será de rigor. A opção pelo regime estatutário impõe as devidas alterações em razão da natureza transitória do vínculo (ausência de estabilidade e de vantagens pecuniárias pessoais, como adicional por tempo de serviço), havendo ainda a possibilidade de reconhecimento dos direitos constitucionais atribuídos aos servidores ocupantes de cargos públicos. (art. 39, § $3 .^{\circ}$ ). Há tendência jurisprudencial firme no sentido de reconhecer a existência de vínculo estatutário $[\ldots]^{126}$.

A favor de um regime administrativo para os servidores temporários, destacam-se os seguintes autores: Toshio Mukai ${ }^{127}$, Diogo de Figueiredo Moreira Neto ${ }^{128}$, Evaristo de Moraes Filho e Antonio Carlos Flores de Moraes ${ }^{129}$, Telmo Candiota ${ }^{130}$ e Antônio Augusto Junho Anastasia ${ }^{131}$.

Estatuto Federal" (MEDAUAR, Odete. Direito administrativo moderno. 15. ed. São Paulo: Revista dos Tribunais, 2011, p. 290-291).

125 "As relações entre os contratados e a Administração serão reguladas pela legislação de cada localidade, a qual elegerá o regime jurídico a ser adotado, se estatutário ou celetista, ou ainda um regime especial. Qualquer que seja o escolhido, implicará a contratação de obrigações e a aquisição de direitos pelos contratados" (MELO, Frederico Jorge Gouveia de. Admissão de pessoal no serviço público: procedimentos, restrições e controles (de acordo com a Lei de Responsabilidade Fiscal). 2. ed. Belo Horizonte: Fórum, 2009, p. 72).

${ }_{126}$ MOTTA, Fabrício. Contratação temporária por excepcional interesse público. In: DI PIETRO, Maria Sylvia Zanella; MOTTA, Fabrício; FERRAZ, Luciano de Araújo. Servidores públicos na Constituição de 1988. São Paulo: Atlas, 2011, p. 73.

${ }^{127}$ Ao comentar o artigo 37, IX, da Constituição Federal, Toshio Mukai afirma: "A disposição pelo que se verifica, veio alterar em parte o denominado regime especial que era previsto no art. 106 da Emenda Constitucional n. ${ }^{\circ} 1 / 69$ [...]. Este regime, a nosso ver, continuará sendo administrativo e não celetista" (MUKAI, Toshio. Administração pública na Constituição de 1988. 2. ed. São Paulo: Saraiva, 1989, p. 54).

${ }^{128} \mathrm{O}$ autor afirma que os contratados públicos temporários do inciso IX "são servidores regidos por contratos de direito administrativo" (MOREIRA NETO, 1990, p. 19-20). Aduz, ainda, que essa contratação "tem natureza administrativa" (MOREIRA NETO, Diogo de Figueiredo. Curso de direito administrativo.15. ed. Rio de Janeiro: Forense, 2009, p. 375).

${ }^{129}$ Os autores ressaltam: "Inclusive, como conseqüência direta e lógica do regime jurídico único, o contrato por prazo determinado, previsto no inciso IX do art. 37 da Carta Magna, será de natureza administrativa e não trabalhista" (MORAES FILHO, Evaristo de; MORAES, Antonio Carlos Flores de. Introdução ao direito do trabalho. 6. ed. São Paulo: LTR, 1993, p. 245).

${ }^{130}$ Telmo Candiota defende que é administrativo o regime do artigo 37, IX, da CF, devendo a lei estadual ou municipal evitar previsão de contrato baseado no direito civil ou na CLT (CANDIOTA, Telmo. Servidor público: contratação temporária (regime jurídico previsto no art. 37, IX, da CF). Revista Trimestral de Direito Público, São Paulo, n. 6, abr./jun. 1994, p. 174).

131 "A natureza da contratação temporária aludida no dispositivo constitucional é, igualmente, de direito público, ou seja, o contrato é de direito administrativo. Na verdade, ao mencionar 'contrato', o constituinte só autorizou o contrato administrativo ou o de trabalho. Por que afastamos o regime trabalhista? Se o vínculo for de contrato de trabalho, por força de caráter permanente deste, se estará excepcionando o regime único, mediante estabelecimento de vínculo com servidor que não o estatutário" (ANASTASIA, Antônio Augusto Junho. Regime jurídico único do servidor público. Belo Horizonte: Del Rey, 1990, p. 95-96). 
Edmir Netto de Araújo entende que são celetistas os contratados com fundamento na Lei n. ${ }^{\circ} 8.745$, de 9 de dezembro de 1993, com as alterações da Lei n. ${ }^{\circ}$ 9.849, de 26 de outubro de 1999 (artigo 37, IX, da Constituição Federal), sob regime especial ${ }^{132}$.

O referido autor chama a atenção para o que ocorre na Administração estadual de São Paulo: desde o Decreto n. ${ }^{\circ}$ 52.356, de 12 de janeiro de 1970, proibiu-se a contratação de celetistas para a Administração direta, ao mesmo tempo que se erigia a Consolidação das Leis do Trabalho em regime preferencial para as autarquias. As fundações (por seu regime de direito privado) e as empresas estatais (Constituição Federal, artigo 170, § 2. ${ }^{\circ}$ ) já utilizavam tal regime obrigatoriamente.

Afirma o referido autor que o regime "especial" mencionado na Constituição (artigo 37, IX) não foi disciplinado em São Paulo, mantendo-se ainda a tal título o regime dos temporários instituído (antes da Constituição Federal de 1988) pela Lei n. ${ }^{\circ}$ 500/74, preferencialmente estatutários, mas sem gerar estabilidade.

Em São Paulo, com a proibição do Decreto Estadual n. ${ }^{\circ}$ 52.356, de 12 de janeiro de 1970 (de contratações trabalhistas na Administração direta) e a promulgação da Lei n. $^{\circ}$ 500, de 13 de novembro de 1974, a admissão de servidores temporários "precários" passou a se dar pelo regime estatutário (todavia, sem estabilização) ficando a admissão de servidores celetistas (ambos os casos, por "prova de seleção"), conforme art. 14, § 2. ${ }^{\circ}$, do Decreto-Lei Complementar n. ${ }^{\circ} 7$, de 6 de junho de 1969, e nos termos do art. 170, $\S 2 .^{\circ}$, da EC de 1969 , reservada, como pessoal permanente, às autarquias, fundações públicas e empresas estatais, igualmente sem estabilização, por ser praxe a exigência (sem fundamento legal) de opção de FGTS ${ }^{133}$.

A questão não é pacífica na doutrina, e devem-se também estudar os argumentos dos autores que se posicionam a favor de um regime celetista nos casos de contratação do artigo 37, IX, da Constituição Federal.

Como defensor da aplicação da Consolidação das Leis do Trabalho aos servidores temporários, em razão da impossibilidade de se criar um segundo regime jurídico especial, Adilson Abreu Dallari apresenta os seguintes argumentos:

Em se tratando de um regime jurídico de pessoal, de trabalhadores, é certo que esse regime deve atender às garantias conferidas pela Constituição a todos os trabalhadores. Somando-se a isso a competência exclusiva da União para legislar sobre direito do trabalho (art. 22, I), entendemos que o regime jurídico do pessoal contratado pela administração pública para desempenhar, temporariamente, serviços de excepcional interesse público, somente pode ser o regime da CLT [...]. Em consequência, diante da impossibilidade de se criar um segundo regime jurídico especial para o pessoal contratado, resta apenas a

132 ARAÚJO, 2014, p. 310.

${ }^{133}$ ARAÚJO, 2014, p. 296. 
possibilidade de utilização, para contratações temporárias, do regime celetista ${ }^{134}$.

São defensores da Consolidação das Leis do Trabalho como o melhor regime para a contratação temporária no serviço público: Celso Antônio Bandeira de Mello ${ }^{135}$, José Cretella Júnior $^{136}$, Diógenes Gasparini ${ }^{137}$, Celso Ribeiro Bastos e Ives Gandra Martins ${ }^{138}$, André Prado de Vasconcelos ${ }^{139}$, Adriane de Araujo Medeiros, Marisa Tiemann, Neli Andonini, Rosana Santos Moreira ${ }^{140}$ e Petrônio Braz ${ }^{141}$.

${ }^{134}$ DALLARI, 1990, p. 123-125.

${ }^{135} \mathrm{O}$ autor entende que "são servidores empregados contratados, nos termos do art. 37, IX, da Constituição Federal, sob o vínculo trabalhista, para atender a necessidade temporária de excepcional interesse público, sob o regime jurídico específico previsto na Lei n. ${ }^{\circ} 8.745$, de 9.12.1993" (MELLO, 2013, p. 255).

${ }^{136}$ Ao tratar dos temporários, José Cretella Júnior possui o seguinte entendimento: "Há, com efeito, necessidades permanentes e temporárias. No primeiro caso, o cargo ou emprego deverá ser provido por concurso público de provas ou de provas e títulos. É a regra geral, no funcionalismo. Se, entretanto, a necessidade é temporária, a prestação acidental e ad hoc do serviço público pode ser feita mediante contrato - entre o Estado e o agente público -, acordo que fixe a data do desligamento. É a exceção no campo do funcionalismo. Neste caso, atingido o prazo convencionado, resolve-se o contrato pelo rompimento do vinculum iuris entre o agente público e o Estado. Note-se que o contrato celebrado é regido, em grande parte, pela CLT, exceto os 'desvios', por causa da natureza de uma das partes da relação jurídica - o Estado" (CRETELLA JÚNIOR, José. Comentários à Constituição Brasileira de 1988. 2. ed. Rio de Janeiro: Forense Universitária, 1992, v. 4, p. 2204, grifos do autor).

${ }_{137}$ Para Diógenes Gasparini, os agentes temporários desempenham função, não ocupando cargo nem emprego público e o vínculo que celebram com a Administração Pública é o celetista (GASPARINI, 2012, p. 211-213).

${ }^{138}$ Sobre o assunto, Celso Ribeiro Bastos e Ives Gandra Martins assim se manifestam: "A presente Constituição suprime a possibilidade deste terceiro regime. Ao referir-se à contratação, a Lei Maior não deixa dúvidas quanto a tratar-se da Consolidação das Leis do Trabalho como o documento adequado para reger as relações jurídicas deste pessoal. Como vimos, o traço fundamental do regime estatutário é a sua unilateralidade, inadmitindo a negociação ou a transação. Esta forma de acerto das cláusulas que vão compor a relação empregatícia é própria do regime privado traduzido na Consolidação das Leis do Trabalho" (BASTOS, Celso Ribeiro; MARTINS, Ives Gandra. Comentários à Constituição do Brasil. São Paulo: Saraiva, 1992, v. 3, p. 99).

${ }^{139}$ André Prado de Vasconcelos conclui que o melhor regime para a contratação temporária no serviço público é o da Consolidação das Leis do Trabalho: "Diante da contínua modificação da realidade administrativa brasileira, fruto da evolução das relações sociais que justificam a própria existência do Estado, tem-se que a adoção de um modelo de contratação por tempo determinado para atender necessidade temporária de excepcional interesse público baseado no regime jurídico estatutário não mais atende às necessidades da Administração pública brasileira, sendo imperativa a modificação de tal regime jurídico para atingir o desiderato antes delineado. Assim, através da análise histórica, do exame de casos concretos onde o regime estatutário foi aplicado e das alterações legislativas ocorridas após a promulgação da Emenda Constitucional 19/98, demonstra-se que o melhor regime para a contratação temporária no serviço público é o da Consolidação das Leis do Trabalho, aplicado na parte em que trata do contrato de trabalho temporário" (VASCONCELOS, 2003, p. 82).

${ }^{140}$ Em seu estudo sobre o artigo 37 da Constituição Federal, Adriane de Araujo Medeiros, Marisa Tiemann, Neli Andonini e Rosana Santos Moreira concluem: "É servidor público temporário aquele contratado nos termos do inciso IX do art. 37 da CF. Esses servidores são sujeitos vinculados a uma relação de dependência e subordinação, integrando transitoriamente o corpo estatal na qualidade de sujeitos que operam em nome e por conta do Estado. Exercem função pública desvinculada de cargo ou emprego público. Havendo subordinação jurídica desses servidores à administração, a contratação, a que se refere esse dispositivo, não é de natureza civil ou administrativa. Dentro da Carta Magna somente há possibilidade de existirem dois regimes de contratação subordinada: um regime de direito público, ou seja, estatutário; e um regime de direito privado, ou seja, celetista. Inexiste autorização legislativa para instituição de um regime especial que regule essa contratação a prazo. Uma vez que a norma em tela se refere à contratação, o contrato que rege essa relação tem natureza trabalhista" (MEDEIROS, Adriane de Araujo; TIEMANN, Marisa; ANDONINI, 
João Batista de Oliveira Rocha defende um regime intermediário - o contrato administrativo de trabalho - que contivesse os benefícios essenciais da legislação trabalhista, sem seus pesados ônus, e algumas das garantias do estatuto, sem suas inconveniências e mazelas, para o servidor público temporário. Argumenta o autor:

A legislação trabalhista não é, de modo algum, a mais indicada para regular as relações dos servidores estatais, face aos pesados ônus que acarreta ao Estado empregador, por ser ela manifestamente tutelar da pessoa do empregado, não levando em conta as situações especiais da máquina da Administração Pública [...], por outro lado, o estatuto legal, protegendo imediatamente o cargo ou função pública, deve, por instituição, cercar de garantias especialíssimas seu titular, representante do próprio Estado ${ }^{142}$.

Cármen Lúcia Antunes Rocha, com muita propriedade, consolida o seu entendimento sobre qual seria o regime jurídico do servidor temporário afirmando que, qualquer que seja a hipótese determinante da contratação temporária de servidor, o regime jurídico a que ele se submete é diverso daquele que incide e informa o que se impõe na relação entre a entidade pública e o servidor titular de cargo de provimento efetivo:

Em qualquer circunstância, há imperiosa necessidade de haver a identificação do contratado e a definição, expressa e pública (publicidade que se dá, aliás, mediante publicação), dos motivos que conduziram à contratação. Sem a identificação do contratado e a motivação do contrato, não há como o cidadão e os órgãos administrativos competentes fazerem o controle da validade jurídica do comportamento público. Ademais, a temporariedade da contratação condiciona-se pela duração da condição de excepcional interesse público, o que é objeto de verificação e controle a partir do conhecimento dos elementos determinantes daquele cometimento. O regime jurídico que informa a relação funcional acordada entre o contratado e a entidade contratante deve ser estabelecido na lei que prevê a hipótese constitucional e a regulamenta no âmbito de cada qual das entidades políticas ${ }^{143}$.

Dessa forma, aplicar a Consolidação das Leis do Trabalho aos contratos temporários, considerando os contratados como empregados públicos, não é compatível com certos institutos, considerando-se estar diante de situações de excepcional interesse público. De outro lado, entende-se que os contratados são considerados servidores públicos

Neli; MOREIRA, Rosana Santos. Estudo sobre o art. 37 da Constituição Federal. Revista de Direito Administrativo Aplicado, Curitiba, v. 1, n. 1, 1994, p. 437).

141 "Tais contratados não se inscrevem como servidores públicos, mas como empregados públicos, embora possam exercer função atribuída por lei a cargo que deveria estar ocupado por servidor público. São empregados públicos regidos pelo regime celetista e vinculados ao sistema geral de previdência (INSS)" (BRAZ, Petrônio. O servidor público na reforma administrativa. São Paulo: LED - Editora de Direito, 1998, p. 93).

${ }^{142}$ ROCHA, João Batista de Oliveira. O regime jurídico especial do servidor público. Revista de Direito Público, São Paulo, ano VII, n. 37-38, jan./jun. 1976, p. 133.

${ }^{143}$ ROCHA, 1999, p. 245. 
temporários, não ocupando cargo; eles ocupam funções, sem serem submetidos ao processo de concurso público de provas ou provas e títulos, não estando vinculados integralmente ao regime estatutário, que é aplicável aos servidores públicos permanentes. Por isso, defende-se que os servidores públicos temporários possuem um regime próprio, especial, que, pelas suas características, deve aproximar-se mais do regime estatutário.

Não se pode esquecer que o regime jurídico será aquele estabelecido na lei que prevê a hipótese constitucional e a regulamenta no âmbito de cada entidade política. Como afirma Cármen Lúcia Antunes Rocha, seja qual for o conjunto de direitos, deveres e responsabilidades firmadas legalmente para as partes, será aquele sempre uma relação de direito público, firmando-se nos princípios e regras do direito administrativo ${ }^{144}$.

Como os tribunais têm enfrentado essa questão? Há pouco tempo, o Supremo Tribunal Federal reconhecia que, nos contratos temporários firmados pelo Estado, a relação era trabalhista e que a competência para o julgamento de suas ações era da Justiça do Trabalho ${ }^{145}$.

Ocorre que esse entendimento não prevalece mais, pois o Supremo Tribunal Federal reconhece que tais contratos temporários, com base em lei própria, têm natureza de regime jurídico-administrativo ${ }^{146}$. Assim, ao adotar esse posicionamento, o Supremo Tribunal Federal concluiu que a competência para o julgamento das ações que envolvam os servidores contratados temporariamente e o Poder Público é da Justiça Comum (federal ou estadual), e não da Justiça do Trabalho ${ }^{147}$.

Merece ser ressaltado que, não importa a validade do vínculo, a questão será analisada pela Justiça Comum.

Assim, quanto à competência para resolver litígios decorrentes da contratação temporária, no âmbito federal, segundo o regime especial estabelecido na Lei n. ${ }^{\circ} 8.745$, de 9 de dezembro de 1993, cabe à Justiça Comum Federal dirimi-los. Nos estados e municípios que adotarem semelhante regime, a competência será da Justiça Comum, e não da trabalhista ${ }^{148}$.

\footnotetext{
${ }^{144}$ ROCHA, 1999, p. 245.

${ }^{145}$ STF. CC 7128 SC. Tribunal Pleno. Rel. Min. Gilmar Mendes. Julgamento: 2 fev. 2005. DJ, 1. ${ }^{\circ}$ abr. 2005, p. 00006.

${ }^{146}$ STF. Rcl-MC-AgR 4990 PB. Tribunal Pleno. Rel. Min. Gilmar Mendes. Julgamento: 17 dez. 2007. DJe, 047, 13 mar. 2008.

${ }^{147}$ STF. Rcl 5381/AM. Tribunal Pleno. Rel. Min. Carlos Britto. Julgamento: 17 mar. 2008. DJe, 147; STF. RE 573202 AM. Tribunal Pleno. Rel. Min. Ricardo Lewandowski. Julgamento: 21 ago. 2008. DJe, 232.

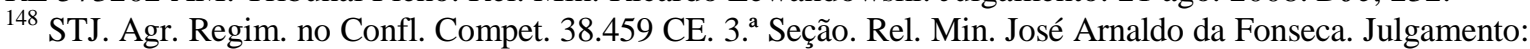

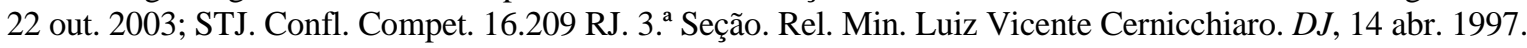


Dessa forma, entende-se que, embora a Constituição Federal utilize o termo "contratação", isso não significa que o regime a que o servidor temporário tenha de submeter-se seja o celetista. Não se pode esquecer que os servidores temporários exercem temporariamente função, não ocupam cargo ou emprego público, e, conforme já foi reconhecido pelo Supremo Tribunal Federal, os contratos temporários, com base em lei própria, têm natureza de regime jurídico-administrativo. Não se está dizendo que o regime deve ser o estatutário, mas defende-se que se trata de um regime especial e que a lei federal, estadual, municipal ou distrital é que vai definir qual será a característica de tal regime, se se aproxima do estatutário ou do celetista, ou se será um misto dos dois regimes.

Em suma, para os servidores temporários, defende-se a existência de um regime especial, próprio, de natureza jurídico-administrativa, mais próximo do regime estatutário. No que concerne ao contrato de que trata o artigo 37, IX, da Constituição Federal, apesar de poder ser regido segundo o que a lei que cada ente da federação estabelecer, é possível aplicar a Consolidação das Leis do Trabalho, ou estabelecer um regime jurídico especial, ou ainda recorrer a regras do Estatuto correspondente. Entende-se que os servidores temporários são mais compatíveis com um regime especial. Portanto, para prestigiar o princípio da igualdade, deve a lei estadual, municipal ou distrital, ao editar a sua lei obedecendo ao comando constitucional, adotar para os seus servidores temporários um regime especial, evitando a previsão de contratos baseados no direito civil ou na Consolidação das Leis do Trabalho.

Assim, para o perfeito andamento do serviço público, os servidores públicos temporários não podem ficar sem nenhuma regra, que se aplique o regime estatutário, ou o regime celetista, ou um regime especial; os servidores públicos devem obedecer a um regime disciplinar, em razão da responsabilidade que possuem ${ }^{149}$.

2.6 A NORMA-MATRIZ DA CONTRATAÇÃO TEMPORÁRIA: O ARTIGO 37, IX, DA CONSTITUIÇÃO FEDERAL

\subsubsection{Eficácia da norma constitucional}

Relembrando a clássica lição de José Afonso da Silva, não há norma constitucional alguma destituída de eficácia. Todas as normas constitucionais têm eficácia, a diferença está no grau de seus efeitos jurídicos. O referido autor discrimina três categorias: a) normas

${ }^{149} \mathrm{O}$ regime disciplinar será estudado e analisado em capítulo próprio. 
constitucionais de eficácia plena; b) normas constitucionais de eficácia contida; c) normas constitucionais de eficácia limitada ou reduzida:

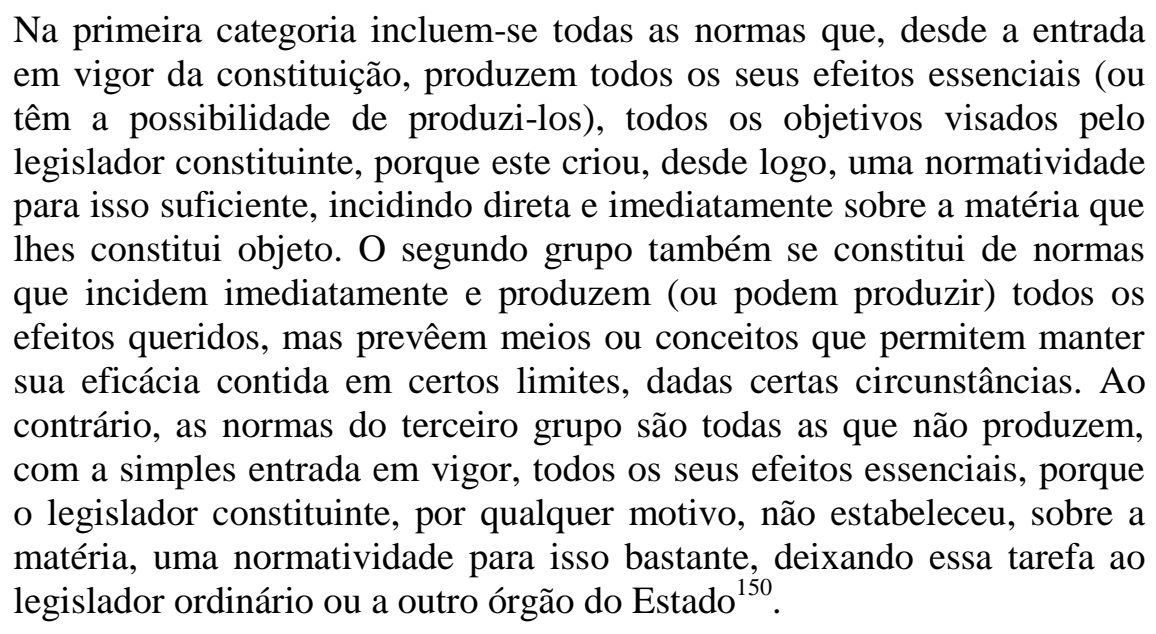

As normas de eficácia plena possuem aplicabilidade direta, imediata, integral. As normas de eficácia limitada são de aplicabilidade indireta, mediata e reduzida. As normas de eficácia contida também são de aplicabilidade direta, imediata, mas não integral, porque estão sujeitas a restrições previstas legalmente ou dependentes de regulamentação que limite sua eficácia e sua aplicabilidade.

Segundo os ensinamentos de José Afonso da Silva, as normas de eficácia limitada são todas as que "dependem de outras providências para que possam surtir os efeitos essenciais colimados pelo legislador constituinte" ${ }^{\prime 151}$. Podem ser de dois tipos: a) as definidoras de princípio institutivo ou organizativo; b) as definidoras de princípio programático.

Assim, as normas constitucionais de eficácia limitada são aquelas que dependem da edição de lei que venha a complementar sua eficácia. Somente quando for editada essa lei, terão eficácia plena. Exemplos: artigo 20, § 2. , da Constituição Federal (“A faixa de até cento e cinquenta quilômetros de largura, ao longo das fronteiras terrestres, designada como faixa de fronteira, é considerada fundamental para defesa do território nacional, e sua ocupação e utilização serão reguladas em lei”); artigo 33 da Constituição Federal (“A lei disporá sobre a organização administrativa e judiciária dos Territórios").

Abraça-se aqui a definição de normas de eficácia de José Afonso da Silva:

são aquelas em que o legislador constituinte regulou suficientemente os interesses relativos a determinada matéria, mas deixou margem à atuação restritiva por parte da competência discricionária do Poder Público, nos

\footnotetext{
${ }^{150}$ SILVA, José Afonso da. Aplicabilidade das normas constitucionais. 7. ed. São Paulo: Malheiros, 2008, p. 81-83.

${ }^{151}$ SILVA, 2008, p. 118.
} 
termos que a lei estabelecer ou nos termos de conceitos gerais nelas enunciados ${ }^{152}$.

As normas constitucionais de eficácia contida são aquelas que não dependem de lei para sua aplicabilidade plena. São de aplicabilidade imediata e direta. A lei apenas conterá seu alcance. Enquanto essa lei não for editada, a norma pode ser aplicada integralmente. Como exemplos: artigo 5. ${ }^{\circ}$, VIII, da Constituição Federal ("ninguém será privado de direitos por motivo de crença religiosa ou de convicção filosófica ou política, salvo se as invocar para eximir-se de obrigação legal a todos imposta e recusar-se a cumprir prestação alternativa, fixada em lei”); artigo 5. ${ }^{\circ}$ XIII, da Constituição Federal ("É livre o exercício de qualquer trabalho, ofício ou profissão, atendidas as qualificações profissionais que a lei estabelecer").

Como se enquadra a norma objeto de estudo, insculpida no artigo 37, IX, da Constituição Federal, que dispõe que "a lei estabelecerá os casos de contratação por tempo determinado para atender a necessidade temporária de excepcional interesse público”, na classificação proposta?

Depreende-se que a lei deverá indicar as situações incomuns ou urgentes que permitem a contratação temporária sem concurso, bem como o prazo de duração, sem esquecer a excepcionalidade da medida e a impossibilidade de que os contratos se eternizem no tempo.

Cabe à lei definir o tipo de situação ensejadora dessa contratação por tempo determinado. Portanto, não haverá como supor que a lei em apreço deva indicar cargos ou empregos a que se possa chegar, sem concurso, por meio dos contratos temporários aludidos. Não há como arrolá-los ou qualificá-los, pois o que a Constituição certamente quis obviar foi o enfrentamento de situações anômalas, de exceção, logo, de repercussões imprevisíveis. Daí a impossibilidade de antecipar quais as funções e quantas demandariam provisório preenchimento para atender as contingências suscitadas por eventos invulgares $^{153}$.

No âmbito federal, foi editada a Lei n. ${ }^{\circ} 8.745$, de 9 de dezembro de 1993, que sofreu inúmeras alterações pelas seguintes leis: Lei n. ${ }^{\circ}$ 9.849/99, Lei n. ${ }^{\circ}$ 10.667/2003, Lei n. ${ }^{\circ} 11.123 / 2005$, Lei n. ${ }^{\circ} 11.204 / 2005$, Lei n. ${ }^{\circ} 11.784 / 2008$, Lei n. ${ }^{\circ}$ lei 12.314/2010, Lei n. ${ }^{\circ}$ 12.425/2011, Lei n. ${ }^{\circ}$ 12.772/2012, Lei n. ${ }^{\circ}$ 12.871/2013 e Lei n. ${ }^{\circ}$ 12.998/2014.

${ }_{152}^{152}$ SILVA, 2008, p. 116.

${ }^{153}$ MELLO, 1991, p. 80. 
Sobre o artigo 37, IX, da Constituição Federal, são válidos os ensinamentos de Celso Antônio Bandeira de Mello:

Trata-se, aí, de ensejar suprimento de pessoal perante contingências que desgarrem da normalidade das situações e presumam admissões apenas provisórias, demandadas em circunstâncias incomuns, cujo atendimento reclama satisfação imediata e temporária (incompatível, portanto, com o regime normal de concursos). A razão do dispositivo constitucional em apreço, obviamente, é contemplar situações nas quais ou a própria atividade a ser desempenhada, requerida por razões muitíssimos importantes, é temporária, eventual (não se justificando a criação de cargo ou emprego, pelo quê não haveria cogitar do concurso público), ou a atividade não é temporária, mas o excepcional interesse público demanda que se faça imediato suprimento temporário de uma necessidade (neste sentido, "necessidade temporária"), por não haver tempo hábil para realizar concurso, sem que suas delongas deixem insuprido o interesse incomum que se tem de acobertar ${ }^{154}$.

E se não houver lei? Concorda-se com a posição de Celso Antônio Bandeira de Mello, para quem é possível efetuar contratações baseadas no artigo 37, IX, da Constituição Federal antes de editada a lei futura, pois, em razão da dinâmica do mundo, podem surgir necessidades, situações urgentes que não admitem a inércia legislativa.

É que as necessidades que vêm suprir não aguardam o surgimento da lei em apreço para, só então, disciplinadamente irromperem. Visto que a Constituição as considerou de relevo suficiente para lhes dedicar uma atenção peculiar, seria incabível admitir que a inércia legislativa paralisasse a operatividade imediata do preceito, inibindo se extraísse dele tudo que fosse, desde logo, aproveitável ${ }^{155}$.

Em algumas decisões, o Supremo Tribunal Federal tem exigido a previsão em lei dos casos possíveis de contratação temporária ${ }^{156}$.

Ao comentar o voto do relator, Ministro Maurício Correa, proferido na ADI n. ${ }^{\circ}$ 2.125-7 - "No mínimo a norma atacada teria que ser específica, designando as atividades a serem ocupadas por contratação temporária e não genérica e abrangente como acabou por ser redigida [...]"-, Florivaldo Dutra de Araújo afirma tratar-se de interpretação equivocada do Texto Constitucional, que prejudica sua adequada aplicação: "Por mais que o legislador queira, não é capaz de imaginar, a priori, todos os casos específicos em que, no futuro, poderão surgir necessidades temporárias de excepcional interesse público" ${ }^{157}$.

\footnotetext{
${ }^{154}$ MELLO, 2013, p. 290, grifos do autor.

${ }_{155}$ MELLO, 1991, p. 83.

156 ADI n. ${ }^{\circ}$ 2.125-7, RE 168.566; ADI-MC 890; ADI-MC 1.219; ADI 1.500; TRF3 - AI 01050946820074030000 - Sexta Turma - Relator Desembargador Federal Mairan Maia - Decisão: 15 dez. 2011 - Publicação: 12 jan. 2012.

157 ARAÚJO, Florivaldo Dutra de. Requisitos constitucionais para a contratação temporária de servidores públicos. In: FORTINI, Cristiana (Org.). Servidor público: estudos em homenagem ao professor Pedro Paulo de Almeida Dutra. Belo Horizonte: Fórum, 2009, p. 124-126.
} 
Segundo Florivaldo Dutra de Araújo, o entendimento de que todos os casos de contratação temporária devam estar previstos em lei tem gerado, no âmbito federal, um acentuado casuísmo legislativo, quase sempre por meio de medidas provisórias, editadas toda vez que o Executivo encontra-se diante de nova situação considerada de excepcional interesse público. Completa o autor: "Bem melhor que esse casuísmo legislativo seria a edição de leis que trouxessem previsões de contratação mediante conceitos abertos ${ }^{158}$, a serem aplicados pelo administrador, em cada caso, pela emissão de atos administrativos motivados"159.

Ivan Barbosa Rigolin entende que a norma do artigo 37, inciso IX, da Constituição Federal, a um só tempo, é de eficácia contida e de eficácia plena. Explica:

Contida quanto à necessidade de que a lei seja editada para disciplinar o regime especial; plena quanto à limitação de competência, ratione materiae, a que se deve sujeitar aquela lei, ou seja: ela só poderá disciplinar - e poderá fazê-lo desde já - "casos de contratação por tempo determinado para atender a necessidade temporária de excepcional interesse público". Quanto ao trecho entre aspas o comando constitucional é inequívoco e dá todos os elementos essenciais à sua inteligência e à edição da lei, a qual, portanto, já pode, dentro daquelas limitações, ser editada; quanto a isso é, então, de eficácia plena ${ }^{160}$.

Defende-se que o comando constitucional do artigo 37, IX, exige a edição de uma lei que venha completá-lo e conferir-lhe possibilidade de aplicação. Trata-se, pois, de típica norma de eficácia limitada, pois precisa de uma legislação futura, observados os casos de necessidade temporária de excepcional interesse público.

E surge a seguinte questão: qual será o regime jurídico aplicado quando não houver lei disciplinando? Entende-se que poderia haver remissão ao regime estatutário a que pertence a unidade da Federação, seja federal, estadual ou municipal, aplicando os dispositivos no que couber aos servidores temporários.

\subsubsection{Competência legislativa concorrente: legislação no âmbito federal, estadual, municipal e distrital}

Quanto à competência para a edição da lei, em razão da autonomia dos entes da federação, trata-se de uma competência legislativa concorrente, cabendo à União, ao

\footnotetext{
${ }^{158}$ A aplicação da técnica dos conceitos abertos poderia ser uma alternativa, mas deve ser utilizada com bastante cuidado e atenção, observando-se os preceitos legais, os princípios e os limites da discricionariedade (BASTOS, Aline Maria Dias. Conceitos jurídicos indeterminados: discricionariedade ou vinculação? 2002. 216 f. Dissertação (Mestrado em Direito) - Faculdade de Direito, Universidade de São Paulo, São Paulo, 2002.

${ }^{159}$ ARAÚJO, 2009, p. 125-126.

${ }^{160}$ RIGOLIN, 1989, p. 94, grifos do autor.
} 
Estado, ao Distrito Federal e ao Município a edição de lei que estabelecerá as situações de contratação temporária.

Celso Antônio Bandeira de Mello entende que caberá a cada uma das esferas a edição da lei, conforme se trate de serviços da União, dos estados, dos municípios ou do Distrito Federal:

[...] não só pelas respectivas autonomias na organização dos próprios serviços, quanto pelo fato do dispositivo em causa não haver estabelecido a restrição óbvia - se o desejasse - caso em que mencionaria lei federal. Como não o fez, há de prevalecer a regra - não a exceção - ainda que se pudesse preferir solução diversa ${ }^{161}$.

Cármen Lúcia Antunes Rocha adota o seguinte posicionamento:

$\mathrm{Na}$ esteira da norma constitucional, sobreveio a Lei $n .^{\circ} 8.745 / 93$, que estabelece os casos de contratação temporária para os órgãos entidades autárquicas e fundacionais federais, a dizer, sendo lei federal, aplicável apenas às pessoas que compõem a Administração Pública Federal.

Compete aos Estados e aos Municípios editar as suas respectivas leis sobre o assunto, garantindo-se a plena aplicação do dispositivo constitucional, segundo o que se contém em cada entidade para a sua administração ${ }^{162}$.

Cristiana Fortini e Flávia Pieve, ao tratar do assunto, ressaltam:

O ente político interessado em se valer do instituto deverá editar lei específica para realizar as contratações temporárias, discriminando as situações incomuns ou urgentes que autorizam e o prazo de duração, sem perder de vista a excepcionalidade da medida e a impossibilidade de que os pactos se prolonguem por lapso temporal desmesurado. Vale dizer: a regra constitucional traz condições que não podem por óbvio, ser desprezadas pelo legislador ordinário. A lei ordinária somente pode se amoldar ao texto constitucional à medida que arrola situações invulgares e consigna prazos não extensos para a relação jurídica contratual ${ }^{163}$.

Márcio Barbosa Maia e Ronaldo Pinheiro de Queiroz entendem que o primeiro requisito da contratação temporária é a sua previsão em lei formal, editada no âmbito de cada unidade federativa, pois as questões referentes à forma de admissão de pessoal para o serviço público estão abrangidas na autonomia político-administrativa da União, dos estados, do Distrito Federal e dos municípios.

No âmbito da União vigora a Lei n. ${ }^{\circ} 8.745 / 93$, a qual estabelece os casos e as condições gerais para os contratos por prazo determinado para atender a excepcional interesse público.

${ }^{161}$ MELLO, 1991, p. 81

${ }^{162}$ ROCHA, 1999, p. 241.

${ }^{163}$ FORTINI, Cristiana; PIEVE, Flávia Cristina Mendonça Faria da. As terceirizações e as contratações temporárias realizadas pela Administração Pública: distinção entre as duas figuras e o impacto na LRF. In: FORTINI, Cristiana (Org.). Terceirização na Administração: estudos em homenagem ao professor Pedro Paulo de Almeida Dutra. 2. ed. Belo Horizonte: Fórum, 2012, p. 22. 
Por outro lado, virou praxe no Governo Federal, ao criar uma entidade pública (ou mudar apenas o seu rótulo), autorizar as contratações temporárias na respectiva lei instituidora. Foi o que ocorreu com todas as agências reguladoras (ANATEL, ANP, ANEEL, ANA etc.), com menção expressa na lei geral das agências (Lei n. ${ }^{\circ}$ 9.986/2000) e com o CADE (Lei n. ${ }^{\circ} 8.884 / 94$ e Lei n. $\left.^{\circ} 10.843 / 2004\right)^{164}$.

Como já referido, no âmbito federal, foi editada a Lei n. ${ }^{\circ}$ 8.745/93, que será objeto de um estudo mais aprofundado nos capítulos seguintes e que merecerá uma maior atenção.

Quanto a leis editadas pelos estados, tomar-se-á como exemplo o Estado de São Paulo e o Estado do Pará.

No Estado de São Paulo, a lei dos temporários (Lei n. ${ }^{\circ}$ 500, de 13 de novembro de 1974) dispõe, no artigo 33, que o servidor admitido em caráter temporário está sujeito aos mesmos deveres, proibições, regime de responsabilidade e penas disciplinares de repreensão, suspensão e multa, vigentes para o funcionário público civil do Estado (Lei n. ${ }^{\circ}$ 10.261/68).

Edmir Netto de Araújo comenta a experiência do Estado de São Paulo, que, por meio da Lei Complementar n. ${ }^{\circ} 1.093$, de 16 de julho de 2009 (regulamentada pelo Decreto

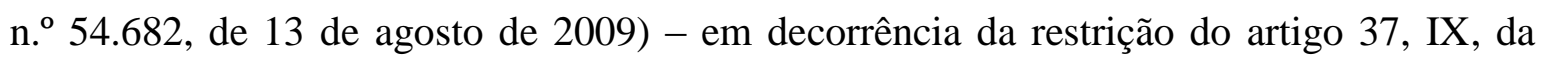
Constituição Federal e também em atenção ao disposto no artigo 115, X, da Constituição Estadual -, instituiu a possibilidade de contratação de agentes públicos por tempo determinado, para, como dizem as normas constitucionais, "atender a necessidade temporária de excepcional interesse público":

Não se trata, portanto, de provimento de cargos, nem de funçõesatividade de que falam a Lei Complementar n. ${ }^{\circ} 180 / 78$ ou a Lei $n .^{\circ}$ 500/74, mas de empregos temporários, não necessariamente "empregados públicos". Também não são esses agentes servidores "temporários", como costumam ser designados os admitidos pelo regime estatutário da Lei n. ${ }^{\circ}$ 500/74, pois, na verdade, a partir da publicação dessa lei passam a ser vedadas as admissões por esta última lei, extinguindo-se as funções-atividade que na ocasião estiverem vagas, e as demais, na vacância; também é a mesma situação para as contratações nesse regime efetuadas depois da Lei Complementar $n .^{\circ}$ 1.010/2007, findo o prazo (quando há) da contratação, ou, não o havendo, depois de 12 meses contados da publicação da Lei Complementar n. ${ }^{\circ} 1.093$, de 167-2009 (esta última hipóteses, do art. 25, II, desse diploma legal, teve recentemente a aplicação suspensa pelo TJSP, em sessão de 14-10-2009). A possibilidade de contratação é deferida (art. 23) à Administração direta e às autarquias que possuam regime estatutário de pessoal ${ }^{165}$.

\footnotetext{
${ }^{164}$ MAIA, Márcio Barbosa; QUEIROZ, Ronaldo Pinheiro de. O regime jurídico do concurso público e o seu controle jurisdicional. São Paulo: Saraiva, 2007, p. 44.

${ }^{165}$ Edmir Netto de Araújo resume as principais características da Lei Complementar n.o 1.093 , de 16 de julho
} 
Quanto ao regime jurídico adotado no Estado de São Paulo, Edmir Netto de Araújo entende aproximar-se bastante da Consolidação das Leis do Trabalho:

O regime jurídico instituído guarda (embora não se diga isso expressamente na lei) inúmeras semelhanças com o da CLT (p. ex., 13. ${ }^{\circ}$, férias, licenças, regime previdenciário geral), cogitando-se até mesmo se em eventual reclamação trabalhista o Poder Judiciário não reconheceria o vínculo laboral, em casos de indenizações, 1/3 de férias, FGTS e outras diferenças. Observa-se ainda a vedação de acumulação de cargos, empregos ou funções (art. 4. ${ }^{\circ}$, II) e aplicabilidade da observância de deveres e vedações constantes do Estatuto do Funcionário Público ${ }^{166}$.

\section{No âmbito do Estado do Pará, a Lei Estadual n. ${ }^{\circ}$ 5.389/87 introduziu a contratação}

temporária, sendo a matéria regulamentada atualmente pela Lei Estadual Complementar n. ${ }^{\circ}$

07/91 e suas diversas alterações, que dispõe assim na sua atual redação:

Art. $1^{\circ}$ A Administração Direta, Autárquica e Fundacional, de qualquer dos Poderes do Estado, inclusive Tribunais de Contas e Ministério Público, poderão contratar pessoal por tempo determinado para atender necessidade temporária de excepcional interesse público.

de 2009: 1) Contratação possível quando há urgência e inadiabilidade de atendimento de situação de excepcional interesse público (art. 1. ${ }^{\circ}$, I). Observa-se que o dispositivo trata da urgência e a Constituição Federal não fez referência a esse requisito. 2) Necessidade de pessoal para prestação de serviços essenciais (art. 2..$^{\circ}$ ), pelos motivos descritos nas alíneas $a$ a $d$ do inciso II, como número significativo de dispensas, demissões, exonerações, falecimentos, criação de novas unidades e outros; serviços eventuais e transitórios (inciso III), das alíneas $a$ a $c$, como projetos de informática e outros de natureza técnica especializada; e ainda para suprir atividade docente nos casos das alíneas $a$ a $c$ do inciso IV. 3) A contratação, que dependerá da existência de recursos orçamentários, só será efetuada pelo prazo estritamente necessário, não excedendo 12 meses (art. $7^{\circ}$ ), e só pode ser feita se estiver tramitando processo para realização de concurso público ou para criação de cargos públicos (art. 1. ${ }^{\circ}$, parágrafo único); terá de ser autorizada pelo Governador do Estado (art. 2. ${ }^{\circ}$, I) e formalizada pelos Secretários de Estado, dirigentes de autarquia e Procurador-Geral do Estado (art. 2. ${ }^{\circ}$, caput), e será precedida de processo seletivo simplificado, com ampla divulgação (art. 2. ${ }^{\circ}$, II e III). Findo o prazo de vigência, o contrato é extinto automaticamente. Andou bem a lei paulista ao vincular a contratação temporária a: existência de recursos orçamentários, prazo necessário, concurso público em andamento. 4) É facultado ao órgão ou autarquia interessados a contratação, previamente à abertura de seu respectivo processo seletivo, de remanescentes aprovados e ainda não nomeados em decorrência de concurso público para provimento de cargos da Administração direta, correspondentes à atividade requerida, na ordem de classificação ( $\left.\operatorname{art} .5^{\circ}\right)$, remanescentes estes que não perderão o direito à classificação obtida no concurso público (art. 5. ${ }^{\circ}$, parágrafo único). Uma importante solução: aproveitar os remanescentes aprovados e ainda não nomeados em decorrência de concurso público. 5) A remuneração do contrato não pode ser superior à de cargo, emprego ou função assemelhado na Administração estadual (art. 11). 6) A mesma pessoa, extinto o contrato, não poderá ser novamente contratada por esse regime antes de decorridos 200 dias de seu término (art. $6^{\circ}$ ), a fim de evitar que a pessoa permaneça eternamente na função. 7) Além do término do prazo (art. 7. $.^{\circ} \S 2 .^{\circ}$ ), o contrato pode ser extinto por iniciativa do contratado (art. 8. ${ }^{\circ}, \mathrm{I}$ ): pelo retorno do titular de cargo, emprego ou função permanente (art. 8. ${ }^{\circ}$, II; art. $1^{\circ}$, II, c e d, IV, c); por extinção ou conclusão do objeto (art. $8^{\circ}$, III; art. 1..$^{\circ}$, I e III), por infração legal ou contratual (art. $\left.8 .^{\circ}, \mathrm{V}\right)$; ou criação, classificação ou provimento do cargo (art. 8. ${ }^{\circ}, \mathrm{VI}$; art. 1. $.^{\circ}, \mathrm{IV}, a$ e $b$ ); se o contratado (art. 8. $\left.{ }^{\circ}, \mathrm{VII}\right)$ for nomeado para cargo do concurso do qual era remanescente aprovado (a), for convocado para serviço militar obrigatório (b) ou assumir mandado eletivo (c); finalmente, por conveniência da Administração (art. 8. ${ }^{\circ}$, VIII). Ressalta o referido autor que as extinções (dispensas) dar-se-ão sem indenização, observadas as garantias do devido processo legal, da ampla defesa e do contraditório nas hipóteses dos incisos I a VIII do artigo 8. ${ }^{\circ}$; ou então, com indenização de uma remuneração mensal do contratado (ou média mensal), no caso de conveniência administrativa (art. $8 .^{\circ}$, VIII). (ARAÚJO, 2014, p. 298-299, grifos do autor).

${ }^{166}$ ARAÚJO, 2014, p. 298, grifo do autor. 
Parágrafo Único - Casos de excepcional interesse público, para os efeitos desta Lei, além do caso fortuito ou de força maior, são, por exemplo: falta ou insuficiência de pessoal para a execução de serviços essenciais; necessidade de implantação imediata de um novo serviço: greve de servidores públicos, quando declarada ilegal ou pelo órgão judicial competente.

Nesse sentido, é possível asseverar que a Administração Pública está legalmente autorizada a contratar servidores temporários. No entanto, conforme os requisitos listados tanto na Constituição Federal de 1988 quanto na Constituição Estadual do Pará de 1989, bem como na Lei Complementar n. ${ }^{\circ}$ 07/91, a contratação temporária deve ter por fim atender necessidade de excepcional interesse público. Assim, existindo excepcional interesse público, agregado aos outros requisitos, haverá legitimidade para a contratação temporária.

Dessa forma, no Estado do Pará vigora a Lei Complementar n. ${ }^{\circ}$ 07/91, que, em seu artigo $4{ }^{\circ}$, dispõe:

O regime jurídico dos servidores contratados é de natureza administrativa, regendo-se por princípios de direito público, aplicandose-lhes, durante o exercício da função ou a realização do serviço, naquilo que for compatível com a transitoriedade da contratação, os direitos e deveres referidos no Estatuto dos Funcionários Públicos, contando-se o tempo da prestação de serviço para o fim do disposto no art. $33, \S 3 .^{\circ}$, da Constituição do Estado do Pará.

Ana Maria Rodrigues Barata noticia que o Estado do Pará tem feito, desde 1987, contratações temporárias e, desde 1991, tem prorrogado, sucessivas vezes, os contratos temporários:

\begin{abstract}
A Lei n. ${ }^{\circ} 5.389 / 87$ introduziu a contratação temporária, revogada pela Lei Complementar n..$^{\circ}$ 07/91, que regulamentou novamente tais contratações já sob o perfil da Constituição Federal de 1988. Assim, desde 1987, possivelmente o Estado ainda possui servidor nessa condição perfazendo mais de 15 anos de vínculo funcional. Com a constitucionalização dessas relações funcionais, imaginava-se a retomada da legalidade das contratações. Ledo engano. O arranjo político que passou a ser praticado proporcionou intermináveis prorrogações desses contratos, sempre da lavra do Deputado Antenor Bararu, cujas normas eram conhecidas como "Lei Bararu""
\end{abstract}

Hoje a contratação temporária no Estado do Pará é regulada pela Lei Complementar n. ${ }^{\circ}$ 07, de 25 de setembro de 1991. Afirma Ana Maria Rodrigues Barata que, embora a lei estabeleça o prazo máximo de contratação e proíba novas prorrogações, o que se viu foram

${ }^{167}$ BARATA, Ana Maria Rodrigues. A inconstitucionalidade da Lei Complementar n. ${ }^{\circ} 040$ de 25 de junho de 2002, que transfere servidores temporários para quadro suplementar da Administração Pública Estadual. Boletim Informativo Defesa Comunitária e da Cidadania do Ministério Público do Estado do Pará, Belém, n. 12. v. 7, 2003, p. 34, grifo da autora. 
sucessivas prorrogações dos prazos dessas contratações. Exemplifica a autora: a Lei Complementar n..$^{\circ}$ 11/93 autorizou a prorrogação dos contratos até 31 de dezembro de 1993; a Lei Complementar n. ${ }^{\circ}$ 19/94 prorrogou os contratos até 31 de dezembro de 1995; a Lei Complementar n. ${ }^{\circ} 30 / 95$ prorrogou-os até 31 de dezembro de 1998; a Lei Complementar n. ${ }^{\circ}$ 36, de 4 de dezembro de 1998, prorrogou-os até 31 de dezembro de 2002, sempre recomendando a realização de concurso público.

Na revogada Lei Estadual n. ${ }^{\circ}$ 5.389/87, o prazo máximo de contratação não poderia ultrapassar 24 (vinte e quatro) meses. Já a redação original da Lei Estadual Complementar n. ${ }^{\circ}$ 07/91 previa que a contratação temporária seria pelo prazo máximo de 6 (seis) meses, prorrogável uma única vez por igual período.

A atual redação da Lei Estadual Complementar n. ${ }^{\circ}$ 07/91, alterada pela Lei Estadual Complementar n. ${ }^{\circ}$ 77/2011, ainda vigente, prevê que a contratação temporária pode estender-se pelo período de um ano, prorrogável pelo mesmo prazo uma única vez.

No Estado do Pará, várias leis sucederam-se à Lei Complementar n. ${ }^{\circ}$ 07/91, com o propósito de prorrogar os contratos temporários para além do prazo previsto originalmente (LC n. ${ }^{\circ} 11 / 93$, LC n. $^{\circ} 19 / 94$, LC n. $^{\circ} 30 / 95$, LC n. $^{\circ} 36 / 98$, LC n. $^{\circ} 40 / 2002$, LC n. $^{\circ} 42 / 2002 \mathrm{e}$ LC n. ${ }^{\circ}$ 47/2004).

As diversas prorrogações desses contratos temporários - diga-se de passagem, feitas de forma indevida por lei - provocaram a declaração de inconstitucionalidade pelo Supremo Tribunal Federal de uma dessas leis - LC n. ${ }^{\circ}$ 40/2002 -, que tentou manter esses servidores temporários na Administração, criando um quadro suplementar.

Isso culminou na propositura de ação civil pública pelo Ministério Público do Trabalho contra o Estado do Pará (processo judicial n. ${ }^{\circ}$ 187/2005, 13. ${ }^{\text {a }}$ Vara do Trabalho do Tribunal Regional do Trabalho da 8. ${ }^{a}$ Região). A referida ação civil pública resultou em um acordo firmado entre as partes e homologado pelo juízo do feito em 9 de maio de 2005 , que fora objeto de sucessivos aditivos, sendo o último deles firmado em 13 de junho de 2011, ficando consignado que o prazo final para o distrato dos servidores temporários mantidos irregularmente seria 31 de março de 2012.

Houve, portanto, no Estado do Pará uma situação de sucessivas prorrogações de contratos temporários, desvirtuando a referida espécie de contratação, o que foi rechaçado pelo Poder Judiciário, a Administração estadual sendo obrigada a adequar-se aos ditames legais e a dispensar a totalidade dos servidores que eram mantidos irregularmente no serviço público. 
No Município de São Paulo, vigora a Lei n. ${ }^{\circ}$ 9.160, de 3 de dezembro de 1980, que, em seus artigos 20 e 21, estende o regime da Lei n. ${ }^{\circ} 8.989 / 79$ :

Art. 20 - Os servidores admitidos ou contratados nos termos da presente lei estão sujeitos aos mesmos deveres, às mesmas proibições e ao mesmo regime de responsabilidade, bem como às penas de repreensão e suspensão, vigentes para o funcionário público municipal.

Art. 21 - Estendem-se aos servidores admitidos ou contratados as proibições de acumulação de cargos e funções previstas nos artigos 58 a 61 da Lei n. ${ }^{\circ} \underline{8.989}$, de 29 de outubro de 1979.

Assim, cada unidade da federação, em conformidade com suas peculiaridades e em virtude de sua autonomia, editará a lei que estabelece as situações de contratação temporária. Portanto, cada ente político deverá editar lei específica para realizar as contratações temporárias. O problema é o seguinte: cada esfera política poderá escolher o regime que melhor se adapte às suas necessidades, seja o estatutário, seja o celetista, seja um regime próprio.

O grande perigo é a falta de uniformidade, que gera uma desigualdade entre as situações, em razão da quantidade de estados e municípios existentes no Brasil. Com efeito, hoje há um temporário regido pelas normas estatutárias em um Estado e outro temporário regido por normas celetistas em outro Estado. Isso provoca uma sensação de injustiça, pois não há uma isonomia entre os entes da Federação, permite-se que cada um proceda de uma forma, adotando o regime estatutário, o regime celetista ou um regime especial, de acordo com suas conveniências.

Como a Constituição Federal diz que compete privativamente à União (artigo 22, XXVII) legislar sobre normas gerais de licitação e também de contratos administrativos, o ideal - e o adequado - seria que essas normas fossem gerais e que a contratação fosse uniformizada em todo o território nacional.

A melhor solução seria estabelecer a observância de um regime especial de natureza administrativa por todos os entes da federação, aplicando-se o que for compatível com a transitoriedade da contratação (função), os direitos e deveres referidos no respectivo estatuto dos servidores públicos sendo estabelecidos em um contrato administrativo.

Poderia, ao menos, ser adotado um regime jurídico disciplinar único, independentemente do regime constante da lei específica para realizar as contratações temporárias. O regime disciplinar seria aplicado em todas as situações referentes ao servidor público temporário. 


\subsubsection{Requisitos constitucionais para a contratação temporária de servidores públicos}

É importante analisar o artigo 37, IX, da Constituição Federal, que está assim redigido: "a lei estabelecerá os casos de contratação por tempo determinado para atender a necessidade temporária de excepcional interesse público”.

Não há unanimidade nem na doutrina, nem na jurisprudência, na interpretação do dispositivo constitucional, embora se tenham passado mais de vinte anos.

Por isso, serão aqui analisados os demais requisitos constantes do texto constitucional: contratação por prazo determinado, necessidade temporária e excepcional interesse público.

\subsubsection{Estipulação de prazo determinado}

O dispositivo constitucional exige contrato e tempo determinado, pois refere-se a contratação por tempo determinado.

Cármen Lúcia Antunes Rocha esclarece que o contrato deve possuir um prazo, não pode ser indeterminado:

O tempo máximo de duração do contrato deve ser previsto, ou tem de ser expressa, pelo menos, a situação cuja pendência permite ou impõe a sua continuação. Não pode haver a indeterminação e a indeterminabilidade da situação que implica manutenção durante um período temporal do contrato, transformando-se em ordinário o que é, pela sua natureza, extraordinário e transitório ${ }^{168}$.

Celso Antônio Bandeira de Mello enfatiza que o contrato deve ser por tempo determinado:

O contrato em apreço há de ser por tempo determinado, como diz o inciso IX, e apenas para enfrentar em caráter transitório a necessidade que demanda satisfação pronta. Daí que o contrato haverá de ser por prazo certo: o estritamente necessário à superação do problema transitório ou à realização do concurso para preenchimento do cargo ou emprego, quando disto se tratar. Por isso, em princípio, não poderá ser prorrogado ou renovado. Isto só se admitirá se incidentes ocorridos durante ou após o concurso impedirem o preenchimento da ou das vagas quando da expiração do prazo contratual ${ }^{169}$.

O contrato por prazo determinado do servidor temporário no direito administrativo é diferente do contrato por prazo determinado do direito do trabalho.

\footnotetext{
${ }^{168}$ ROCHA, 1999, p. 243-244.
}

${ }^{169}$ MELLO, 1991, p. 83. 
Como explica Amauri Mascaro Nascimento, não se confundem também as figuras do trabalhador temporário e do empregado contratado por prazo certo, no âmbito do direito do trabalho:

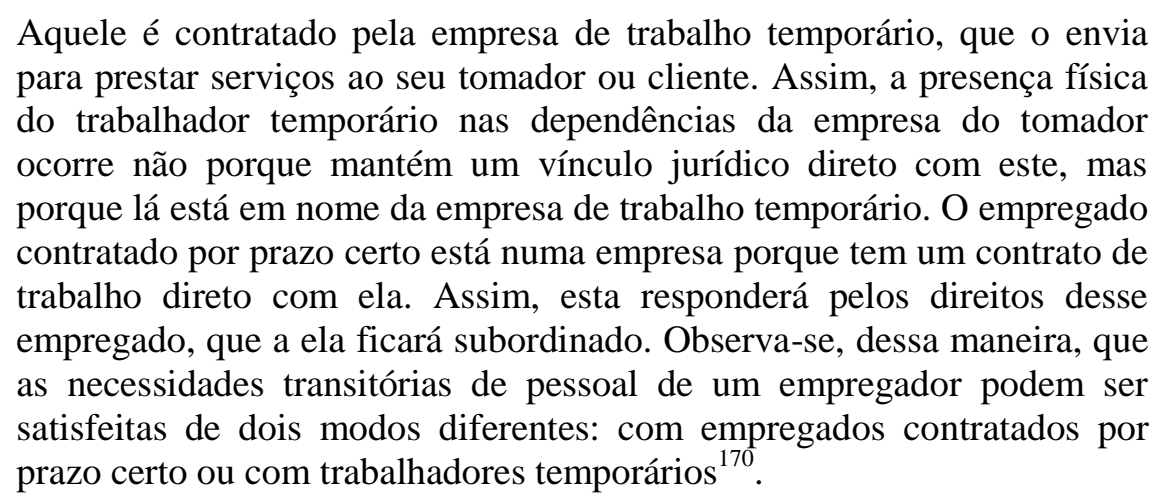

Define-se, no artigo 2..$^{\circ}$ da Lei n. ${ }^{\circ} 6.019 / 74$, o que seria o trabalho temporário no direito do trabalho: "aquele prestado por pessoa física a uma empresa, para atender a necessidade transitória de substituição de seu pessoal regular e permanente ou a acréscimo extraordinário de serviços”. Tal definição é completada com o artigo $4 .^{\circ}$ da mesma Lei: “Compreende-se como empresa de trabalho temporário a pessoa física ou jurídica urbana, cuja atividade consiste em colocar à disposição de outras empresas, temporariamente, trabalhadores devidamente qualificados, por elas remunerados e assistidos".

Assim, à luz do direito do trabalho, tanto no emprego quanto no trabalho temporário há subordinação, mas a subordinação jurídica do trabalhador temporário será com a empresa de trabalho temporário, com a qual o contrato é mantido.

Válidas são as observações de Amauri Mascaro Nascimento a respeito do temporário nos contratos de direito do trabalho, merecem ser transcritas:

Temporário não é empregado. Presta serviços para uma empresa de locação de trabalho temporário. E esta é a empresa que cede serviços para outras, de modo que o trabalhador temporário está subordinado imediatamente à empresa de trabalho temporário da qual recebe a remuneração pela atividade desenvolvida no âmbito de interesse do "tomador" ou "cliente" da empresa de trabalho temporário ${ }^{171}$.

O $\S 1 .^{\circ}$ do artigo 443 da Consolidação das Leis do Trabalho assim dispõe sobre o contrato de trabalho por tempo determinado: "o contrato de trabalho cuja vigência dependa de termo prefixado ou da execução de serviços especificados ou ainda da realização de certo acontecimento suscetível de previsão aproximada".

\footnotetext{
${ }^{170}$ NASCIMENTO, Amauri Mascaro. Curso de direito do trabalho. 25. ed. São Paulo: Saraiva, 2010, p. 1005.

${ }^{171}$ NASCIMENTO, 2010, p. 1006.
} 
Sergio Pinto Martins cita o seguinte exemplo de serviço condicionado à execução de serviço específico: contratação de técnico para treinamento de operadores, na implantação de equipamento altamente sofisticado.

A Consolidação das Leis do Trabalho estabelece quais são as hipóteses em que é possível a celebração do contrato de trabalho por prazo determinado. Uma vez não cumprido o prazo estabelecido, o contrato passa a ser por prazo indeterminado:

No Direito do Trabalho, a regra é a contratação por tempo indeterminado. O contrato de trabalho é um contrato de prestações sucessivas, de duração. Em razão do princípio da continuidade do contrato de trabalho, presume-se que este perdura no tempo. A exceção é a contratação por prazo determinado, de acordo com as determinações específicas contidas na lei. [...] O término do pacto por tempo determinado pode ser medido em razão do número de dias, semanas, meses ou anos, ou em relação a certo serviço específico, como o término de uma obra, ou, se for possível fixar aproximadamente, quando houver o término de um acontecimento, como o término de uma colheita, que se realiza periodicamente em certas épocas do ano. É o contrato de safra, que tem a duração dependente de variações estacionais de atividade agrária (parágrafo único do art. 14 da Lei n. $\left.{ }^{\circ} 5.889 / 73\right)^{172}$.

Para o contrato de trabalho por tempo determinado, eram admitidas as seguintes hipóteses: a) serviço cuja natureza ou transitoriedade justifique a predeterminação do prazo; b) atividades empresariais de caráter transitório; c) contrato de experiência ( $\$ 2 .^{\circ}$ do artigo 443 da Consolidação das Leis do Trabalho).

O contrato de trabalho por tempo determinado foi aprovado pela Lei n. ${ }^{\circ} 9.601$, de 21 de janeiro de 1998. Atualmente, a contratação por tempo determinado é possível em qualquer hipótese, sem que haja a observância das condições determinadas no $\S 2 .^{\circ}$ do artigo 443 da Consolidação das Leis do Trabalho, conforme explica Sergio Pinto Martins:

Para o contrato de trabalho por tempo determinado não são exigidas as condições especificadas no $\S 2 .^{\circ}$, do art. 443 da CLT. O art. $1 .^{\circ}$ da Lei 9.601/98 é expresso em excluir do novo contrato por tempo determinado as referidas condições, disciplinando que, independentemente das condições previstas no citado $\S 2 .^{\circ}$, do art. 443 da CLT, poderá ser feita a contratação por tempo determinado. Assim, não será preciso que o contrato de trabalho por tempo determinado seja feito apenas para serviço cuja natureza ou transitoriedade justifique a predeterminação do prazo ou em razão de atividades empresariais de caráter transitório ${ }^{173}$.

Observa-se que a finalidade dos contratos por prazo determinado ou temporário é diferente no direito do trabalho e no direito administrativo. Ambos tratam de um serviço de natureza transitória, breve, efêmera, temporária. Mas, para o direito do trabalho, é

\footnotetext{
${ }^{172}$ MARTINS, Sergio Pinto. Direito do trabalho. 28. ed. São Paulo: Atlas, 2012, p. 113.

${ }^{173}$ MARTINS, 2012, p. 127.
} 
considerado contrato por tempo determinado aquele que depende de termo prefixado ou rege a execução de serviços especificados, ou, ainda, a realização de um certo acontecimento suscetível de previsão aproximada (por exemplo colheita). Para o direito administrativo, o contratado por tempo determinado tem o seu contrato celebrado para atendimento de uma necessidade temporária de excepcional interesse público, ou seja, deverá haver, como pressuposto fático, a excepcionalidade do interesse público ${ }^{174}$.

O estudo deste trabalho está relacionado ao direito administrativo, ao contrato temporário de excepcional interesse público, em que a situação é "passageira", transitória, o contrato deve ter prazo certo, ou seja, o suficiente para resolver o problema ou para providenciar um concurso.

\subsubsection{Existência de necessidade temporária}

Necessidade temporária é a de tempo limitado, com duração certa, é transitória, é passageira, é provisória, é por um período, por uma época, por um prazo, que não é permanente.

Sobre a temporariedade, são válidas as observações de Cármen Lúcia Antunes Rocha:

É temporário aquilo que tem duração prevista no tempo, o que não tende à duração ou permanência no tempo. A transitoriedade põe-se como uma condição que indica ser passageira a situação, pelo que o desempenho da função, pelo menos pelo contratado, tem o condão de ser precário. A necessidade que impõe o comportamento há de ser temporária, segundo os termos constitucionalmente traçados. Pode-se dar que a necessidade do desempenho não seja temporária, que ela até tenha de ser permanente. Mas a necessidade, por ser contínua e até mesmo ser objeto de uma resposta administrativa contida ou expressa num cargo que se encontre, eventualmente, desprovido, é que torna aplicável a hipótese constitucionalmente manifestada pela expressão "necessidade temporária". Quer-se, então, dizer que a necessidade das funções é contínua, mas aquela que determina a forma especial de designação de alguém para desempenhá-las sem o concurso e mediante contratação é temporária ${ }^{175}$.

Como exemplo do que seja a necessidade temporária pode-se citar: combater surtos epidêmicos, fazer recenseamento, atender a situações de calamidade pública, substituir professor ou admitir professor visitante, inclusive estrangeiro.

${ }^{174}$ MARTINEZ, José Maria de S. O servidor temporário e seu regime jurídico. [200-?]. Disponível em: <http://uj.novaprolink.com.br/doutrina/344/o_servidor_temporario_e_seu_regime_juridico>. Acesso em: 19 ago. 2011.

${ }^{175}$ ROCHA, 1999, p. 242. 


\section{Esclarecendo o assunto, Cármen Lúcia Antunes Rocha cita um exemplo:}

A função de magistério ou de enfermeiro ou médico a prestar o serviço em posto de saúde, para o que existe o cargo, mas que está vago. Até o advento do concurso público, umas como outras das funções oferecidas como exemplo não podem deixar de ser desenvolvidas, pena de comprometimento social. Daí porque, conquanto a necessidade social seja permanente e a previsão administrativa seja de igual natureza, tem-se uma hipótese de "necessidade temporária". A necessidade é temporária quanto à forma de indicação do servidor para desenvolver as atividades, não do seu desenvolvimento, que é permanente ${ }^{176}$.

Um ponto interessante que merece ser ressaltado é o prazo de duração dos contratos. Fala-se em necessidade temporária, em situações de excepcional interesse público, mas, de acordo com a Lei n. ${ }^{\circ} 8.745 / 93$, o prazo pode atingir cinco anos, quando se trate de atividades desenvolvidas no âmbito dos projetos do Sistema de Vigilância da Amazônia (Sivam) e do Sistema de Proteção Amazônia (Sipam).

Tal situação tem sido criticada. Comentando tal dilação, Celso Antônio Bandeira de Mello esclarece:

\footnotetext{
Para que se faça uma ideia do escândalo em que se constitui esta lei, mencione-se apenas que os contratos referidos no art. 2. ${ }^{\circ}, \mathrm{VI}$, "g", isto é, relativos a atividades desenvolvidas no âmbito dos projetos do Sistema de Vigilância da Amazônia - Sivam e do Sistema de Proteção da Amazônia - Sipam, podem ser prorrogados até completarem um período total de cinco anos, a teor do art. $4 .^{\circ}$, parágrafo único, IV. Haja temporariedade nisto! Aliás, o art. 76 da Lei da ANP, o art. 34, § 2. , da lei da ANEEL, o art. 36, § $1 .^{\circ}$, da lei da ANVISA e art. 16 da lei da ANA, como se disse, ao tratar das "agências reguladoras", autorizam a admissão de pessoal técnico "em caráter temporário", por até 36 meses ${ }^{177}$.
}

Diogenes Gasparini cita alguns exemplos de necessidade temporária: restauração do sistema viário e dos serviços de comunicação destruídos por uma inundação; continuidade dos serviços de magistério em razão de afastamento súbito e prolongado do professor titular; vacinação emergencial da população em razão de um surto epidêmico imprevisível; recenseamento e outros levantamentos estatísticos; melhoria do serviço público tornado de baixa qualidade pela falta de servidores e sua continuidade em razão de greve ${ }^{178}$.

Se é uma necessidade temporária, se o Estado deve agir imediatamente sob pena de comprometimento social, então a atividade não pode durar tanto tempo a ponto de não permitir a realização de um concurso público.

\footnotetext{
${ }^{176}$ ROCHA, 1999, p. 242.

${ }^{177}$ MELLO, 2013, p. 290.

${ }^{178}$ GASPARINI, 2012, p. 213.
} 
2.6.3.3 Configuração de excepcional interesse público

Na lição de Hector Jorge Escola, interesse público é o resultado de um conjunto de interesses individuais partilhados por um grupo majoritário de indivíduos, atribuídos a toda a comunidade como consequência dessa maioria, cuja origem resulta do querer axiológico desses indivíduos, tendo um conteúdo concreto e determinável, atual, eventual ou potencial, pessoal e direto. $\mathrm{O}$ interesse público prevalece sobre os interesses individuais, sem aniquilá-los ${ }^{179}$.

Floriano Peixoto de Azevedo Marques Neto ressalta que não se pode mais entender por interesse público algo tão genérico a ponto de defini-lo, ou pela negativa - como interesses não privados -, ou com base em abstratos interesses definidos por um Estado distante das reais necessidades existentes no cada vez mais complexo corpo social. Para ele, deve-se, hoje, enfocar o interesse público como um elo entre interesses privados dotados de legitimidade ${ }^{180}$.

O interesse público tem por sujeito toda a coletividade, todo o grupo social, e, por objeto, bens ou valores essenciais para a vida em sociedade.

Como a ideia de atribuição de poderes ao Estado está fundamentada na realização dos interesses gerais, não se admite que o aparelho estatal, por suas entidades e agentes, atue contra ou sem o interesse público ${ }^{181}$. A atividade administrativa, em toda a sua extensão, deve ser voltada para atender o interesse público.

Mas o que seria o excepcional interesse público para justificar uma contratação temporária, sem concurso público?

Cármen Lúcia Antunes Rocha esclarece o que juridicamente é considerado “excepcional interesse público":

Excepcional é palavra que contém mais de um significado, podendo ser assim considerado o que é alheio, singular, estranho, ou o que é ímpar, irrepetido, fora do ordinário.

Para os efeitos da norma constitucional, poder-se-ia cogitar ser excepcional o interesse público em razão de sua natureza singular, ímpar, extraordinária, ou em razão de sua forma de prestação, que, por ter de ser contínua e implicar prestação imprescindível, tem cunhada uma situação de excepcional interesse na contratação.

\footnotetext{
${ }^{179}$ ESCOLA, Héctor Jorge. El interés público como fundamento del derecho administrativo. Buenos Aires: Depalma, 1989, p. 249-250.

180 MARQUES NETO, Floriano Peixoto de Azevedo. A republicização do Estado e os interesses públicos. 1999. 340 f. Tese (Doutorado em Direito) - Faculdade de Direito, Universidade de São Paulo, São Paulo. 1999, p. 210.

181 ARAÚJO, Edmir Netto de. Os princípios administrativos na Constituição de 1988. Revista da Procuradoria Geral do Estado de São Paulo, São Paulo, n. 34, dez. 1990, p. 135.
} 
Dito de outra forma, a excepcionalidade do interesse pode corresponder à contratação ou ao objeto do interesse ${ }^{182}$.

A referida autora apresenta as seguintes situações:

Pode-se ter situação em que o interesse seja excepcional no sentido de fugir ao ordinário. São hipóteses nas quais se tem uma condição social a demandar uma prestação excepcional, inédita, normalmente imprevista. Por exemplo, é o que ocorre numa contingência epidêmica, na qual a necessidade de médicos em determinada região, especialistas na moléstia contra a qual se há de travar o combate, faz com que se contratem tantos deles para fazer face à circunstância.

Pode-se ter, contudo, situação em que o interesse seja regular, a situação comum, mas advém uma circunstância que impõe uma contratação temporária. É o que se dá quando há vacância de cargo de magistério antes de novo concurso para prover o cargo vago ou quando se tem o afastamento temporário do titular do cargo em razão de doença ou licença para estudo etc., o magistério tem de ser desempenhado, o aluno tem direito a ter aula, e o Estado tem o dever constitucional de assegurar a presença do professor em sala. Há, então, a excepcionalidade do interesse público determinante da contratação ${ }^{183}$.

No último caso, observa Cármen Lúcia Antunes Rocha:

Aqui a excepcionalidade não está na singularidade da atividade ou no seu contingenciamento, mas na imprevista, porém imprescindível, prestação, que impõe que o interesse tenha de ser atendido, ainda que em circunstância excepcional. A necessidade da contratação é temporária, e o interesse é excepcional para que ocorra o desempenho da função naquela especial condição ${ }^{184}$.

Celso Antônio Bandeira de Mello entende que o "excepcional interesse público" não envolve somente os casos que demandem atuação profissional, trabalho, de pessoas físicas alheias ao aparelho administrativo. Propõe a seguinte questão sobre o alcance da expressão "excepcional interesse público", que merece ser transcrita:

Estaria a Lei Maior referindo-se tão só a hipóteses em que o interesse público a ser suprido com a contratação temporária fosse unicamente um interesse do mais supino realce? Ou pretenderia abarcar casos em que o interesse em causa, conquanto não sendo de transcendência extrema, se propusesse ante situação de exceção, ou seja, "excepcional", demandando suprimento urgente, embora - repita-se - sem colocar em xeque a sobrevivência de interesses manifestamente impostergáveis? ? $^{185}$

E o referido autor responde:

Se se optar pela primeira alternativa (interesse relevantíssimo), tirante situações em que a ausência da contratação temporária causasse danos à saúde pública, à paz pública e quejandos, seria terminantemente vedado

${ }^{182}$ ROCHA, 1999, p. 244, grifo da autora.

${ }^{183}$ ROCHA, 1999, p. 244.

${ }^{184}$ ROCHA, 1999, p. 244-245.

${ }^{185}$ MELLO, 1991, p. 81, grifo do autor. 
recorrer à contratação temporária. Donde, se uma administração negligenciasse realizar concurso para preenchimento de cargos ou empregos nos correios ou em museus, teatros ou até mesmo em escolas, seria impossível a ela ou à administração que a sucedesse preencher temporariamente as vagas - até a efetivação do concurso - ou ainda atender emergencialmente situações de incomum afluxo de trabalho para as quais não se tivesse feito previsão de vagas bastantes.

Pelo contrário, em se considerando correta a segunda alternativa (excepcionalidade da situação), poder-se-ia - nos exemplos cogitados suprir de pessoal, temporariamente e em caráter excepcional, os Correios, para manter-lhes o nível de eficiência e presteza, os museus e teatros, para ensejar o cumprimento de sua programação normal de atividade e as escolas, para evitar o declínio da qualidade de ensino ou do asseio dos estabelecimentos $^{186}$.

Aqui se concorda com o posicionamento de Celso Antônio Bandeira de Mello, para quem, apesar da tradição de desmandos da administração brasileira, a interpretação correta da expressão "excepcional interesse público" deve levar à solução de problemas reais.

Deveras, não é de crer que a Lei Magna haja expressado comando que se pretendeu cego a dificuldades concretas com que a Administração pode defrontar e que a deixariam num beco sem saída, com prejuízo dos administrados. Não é de crer, pois, que só haja pretendido oferecer soluções para casos cuja transcendência extrema já de per si autorizaria o uso da via prevista, tornando, pois, prescindenda a regra posta ${ }^{187}$.

Conclui o referido autor que a contratação temporária é cabível nos seguintes casos:

perante situações de emergência, é dizer, "excepcionais", portanto, em que está em pauta um interesse que "excepciona" - de modo transitório a admissão por concurso. Sendo esta a índole do preceito, compreende-se também que a Administração fica posta no indeclinável dever de instaurar de imediato o concurso, para o ulterior provimento definitivo, salvo nos casos em que a demanda de pessoal é em si mesmo temporária, por ser sazonal, ou porque não é previsível sua reprodução ${ }^{188}$.

As palavras-chaves são: emergência, excepcionalidade, transitoriedade, imprevisibilidade, interesse público, que autorizam a contratação temporária.

Diogenes Gasparini considera que a necessidade a ser atendida, além de temporária, há de ser de excepcional interesse público e completa:

Este não há de ser relevantíssimo, mas tão só revelador de uma situação de exceção, de excepcionalidade, que pode ou não estar ligado à imperiosidade de um atendimento urgente. Por certo, não precisa, nem a Constituição Federal exige, que haja a necessidade de um atendimento urgente para legitimar a contratação. Basta a transitoriedade da situação e o excepcional interesse público ${ }^{189}$.

${ }^{186}$ MELLO, 1991, p. 81-82.

${ }^{187}$ MELLO, 1991, p. 82, grifo do autor.

${ }^{188}$ MELLO, 1991, p. 84, grifo do autor.

${ }^{189}$ GASPARINI, 2012, p. 213, grifo do autor. 
Cristiana Fortini e Flávia Pieve não consideram a urgência um requisito exigido pela norma constitucional:

A lei pode estabelecer contratações temporárias para satisfazer demandas a serem enfrentadas, sem que esteja presente a urgência da situação, elemento que, de resto, não aparece na regra constitucional que disciplina a matéria. É o que ocorre no caso de recenseadores, cuja presença não se faz imperiosa repentinamente, mas resulta de um planejamento realizado ao longo de anos. Vale dizer, nem sempre a situação a ser enfrentada traz consigo a marca da urgência, embora em boa parte dos casos as leis fixem casos de contratação temporária para hipóteses que reclamam solução rápida. Assim, mesmo que a regra do concurso público não reclame para o exercício das funções públicas, exigindo-o apenas para provimento de cargos e empregos públicos (excetuados os comissionados e alguns vitalícios), parece consentâneo com os princípios da impessoalidade e da moralidade que o procedimento seja realizado ausente a urgência ${ }^{190}$.

Realmente os princípios da impessoalidade e da moralidade devem nortear a contratação temporária, sendo peças importantes na concretização do comando constitucional de seleção das pessoas que serão contratadas temporariamente.

Sobre o sentido e o alcance da expressão necessidade temporária de excepcional interesse público, Márcio Barbosa Maia e Ronaldo Pinheiro de Queiroz afirmam que a doutrina abriu duas correntes, não totalmente divergentes:

A primeira, que é amplamente majoritária, diz que a necessidade da contratação deve ser sempre para função temporária. Se a necessidade é permanente, o Estado deve processar o recrutamento através do concurso público, via normal de acesso. Portanto, está descartada a contratação para admissão de servidores temporários para o exercício de funções permanentes. Nesse sentido: José dos Santos Carvalho Filho; Adilson Dallari; Celso Ribeiro Bastos; e José Cretella Júnior.

A outra corrente entende que a contratação temporária tem lugar tanto para fazer frente a serviços de caráter temporário, como, e em circunstâncias especiais, a serviços de natureza permanente. Neste último caso sustenta-se que a situação tem que ser deveras excepcional, como, por exemplo, vários funcionários de um determinado hospital pedem aposentadoria em massa, deixando o serviço público totalmente descoberto. Em casos que tais, a contratação seria válida somente pelo tempo necessário para um novo recrutamento via concurso público. Nesse sentido: Celso Antônio Bandeira de Mello e Maria Sylvia Zanella Di Pietro ${ }^{191}$.

Somente diante da situação concreta, poder-se-á analisar se foram ou não preenchidos os requisitos que autorizam a contratação temporária, independentemente de ser para o exercício de atividade permanente ou não, sempre tendo como baliza os

\footnotetext{
${ }^{190}$ FORTINI; PIEVE, 2012, p. 22.

${ }^{191}$ MAIA; QUEIROZ, 2007, p. 45-46.
} 
princípios da motivação, da moralidade, da razoabilidade e da impessoalidade da contratação.

De acordo com o dispositivo constitucional, além do interesse público que deve permanecer em toda atividade administrativa, há situações que fogem à normalidade e demandam um "plus" no interesse público, diante dos acontecimentos do dia a dia. Estarse-ia diante de situações excepcionais que fogem ao controle e autorizariam a contratação temporária.

Ainda em relação aos pressupostos fundamentais da necessidade temporária e do excepcional interesse público, frisa-se que as suas hipóteses devem estar expressas em lei, de forma clara, a fim de facilitar a sua identificação, pois pode acontecer uma indeterminação dos casos em razão dos conceitos jurídicos indeterminados de necessidade temporária e "excepcional” interesse público, o que dá margem a abusos. Ou, ao contrário, o legislador deveria usar expressões abertas de modo a flexibilizar as situações de contratação temporária e evitar uma enxurrada de medidas provisórias?

Os conceitos jurídicos indeterminados são uma arma poderosíssima que deve ser manuseada com bastante cautela, sempre visando o interesse público, a coletividade.

Assim, os requisitos constitucionais devem estar presentes na lei que prevê os casos de contratação temporária. Quando da criação da Lei n. ${ }^{\circ}$ 8.745, de 9 de dezembro de 1993, foram introduzidas situações que expressavam necessidade temporária de excepcional interesse público, em especial relacionadas com saúde, educação, segurança, ambiental, calamidade pública. Hoje, com o incremento de hipóteses criadas pelo legislador, pelas leis e medidas provisórias posteriores, restam dúvidas sobre a constitucionalidade dessas novas situações.

\subsubsection{A teoria dos conceitos jurídicos indeterminados e sua aplicação na interpretação constitucional dos pressupostos da necessidade temporária e do excepcional interesse público}

Para explicar a teoria dos conceitos jurídicos indeterminados, existem duas correntes principais: uma que defende a vinculação e outra que defende a discricionariedade na aplicação dos conceitos jurídicos indeterminados. Na nossa dissertação de mestrado sobre conceitos jurídicos indeterminados, apresentada à Faculdade 
de Direito da Universidade de São Paulo, concluímos que não se pode simplesmente adotar radicalmente uma posição ou outra ${ }^{192}$.

Entende-se que, dependendo do caso concreto e do tipo de conceito utilizado pela norma, a indeterminação do conceito pode levar à discricionariedade ou à vinculação. Destarte, um caminho para solucionar essa questão tão complexa seria a distinção feita entre conceitos de experiência e conceitos de valor, além do exame das circunstâncias de fato, da finalidade normativa, dos princípios e valores do ordenamento, das zonas de certeza positiva e negativa, do critério de razoabilidade e da interpretação.

O conceito de experiência apresenta características perfeitamente individualizáveis, podendo ser determinadas mediante um processo de interpretação da norma. $O$ administrador público, após a interpretação, torna-o preciso, havendo apenas uma solução possível e não remanescendo qualquer margem de discricionariedade na eleição de seu significado. Está-se diante da vinculação. A superação de sua indefinição dá-se, pois, por meio de juízo de legalidade.

Situação diferente diz respeito aos conceitos de valor, que, incorporados às normas, necessitam mais do que interpretação para que seja determinado seu sentido ou conteúdo. Eles podem apresentar significados variados ou imprecisão relativa, em situações fáticas de incidência, o que impede o administrador de precisá-los objetivamente. Faz-se necessária, então, para alcançar a sua significação, que é abstratamente imprecisa, a avaliação subjetiva do agente público competente para aplicá-los a certa situação concreta. E tal exame, geralmente, há de ser feito sob uma perspectiva dinâmica, em sintonia com o cotidiano real, em constante mutação, buscando a efetividade normativa e social do comportamento administrativo.

Assim, após a interpretação, o administrador vai deparar-se com duas ou mais soluções possíveis e válidas, existindo ainda uma margem de liberdade, que nada mais é do que a discricionariedade. $\mathrm{O}$ agente público, ao valorar o conceito, deve utilizar-se de critérios impessoais, valorativos, permitidos pelo sistema, e não pela mente do autor da decisão, que deve sempre se guiar pelo interesse público, portanto, em direção à finalidade pública que pretende atender. A definição do conceito constante da regra jurídica faz-se entre as várias significações possíveis, em tese, à luz da situação de fato.

$\mathrm{O}$ administrador, ante um conceito jurídico indeterminado fornecido por norma legal, deve nele identificar um núcleo mínimo de certeza. Terá, então, condições de saber

${ }^{192}$ BASTOS, 2002, p. 133. 
quais as situações que se enquadram ou não no conceito (zona de certeza positiva e zona de certeza negativa). Esse é o processo de interpretação; se não houver dúvidas, apenas uma solução emergirá. Se houver incerteza, ou seja, se, após a interpretação, várias soluções possíveis forem apresentadas, inicia-se a discricionariedade. Ela reside na zona de penumbra, onde a dúvida permanece.

Repete-se que a discricionariedade, no caso dos conceitos jurídicos indeterminados, é circunscrita a determinados princípios, como os da legalidade, da moralidade administrativa, da razoabilidade, da proporcionalidade, do interesse público e da eficiência.

Não se pode esquecer, ainda, que a Administração Pública é dinâmica e precisa de uma certa liberdade para agir convenientemente diante dos novos problemas presentes no dia a dia.

Cármen Lúcia Antunes Rocha enfatiza a necessidade de as hipóteses do artigo 37, IX, da Constituição Federal estarem expressas em lei:

As hipóteses de "necessidade temporária de excepcional interesse público" têm de ser expressas em lei, pelo menos no que se refere ao fator ou ao critério claro de identificação do que seja validamente considerado como tal, caso contrário, o que pode ocorrer é que se tenha uma indeterminação dos casos que poderão ensejar a aplicação da regra contida naquele dispositivo podendo-se então tomá-lo como um escape para contratações que não configuram necessidade temporária nem "excepcional" interesse público.

Importante, então, é que se estabeleçam os critérios legais para a definição administrativa do que seja a temporariedade e a excepcionalidade. Aquela relativa à necessidade, e esta concernente ao interesse público ${ }^{193}$.

Celso Antônio Bandeira de Mello aponta alguns requisitos para o excepcional interesse público, que serviriam de norte para afastar a zona cinzenta dos conceitos jurídicos indeterminados:

Desde logo, não se coadunaria com sua índole, contratar pessoal senão para evitar o declínio do serviço ou para restaurar-lhe o padrão indispensável mínimo seriamente deteriorado por falta de servidores. Vale dizer: tais contratos não podem ser feitos simplesmente em vista de aprimorar o que já existia e tenha qualidade aceitável, compatível com o nível corrente dos serviços a que está afeita a coletividade a que se destina.

Em segundo lugar, cumpre que tal contratação seja indispensável; vale dizer, induvidosamente não haja meios de supri-la com o remanejamento de pessoal ou redobrado esforço dos servidores já existentes.

Em terceiro lugar, sempre na mesma linha de raciocínio, não pode ser efetuada a instalação ou realização de serviços novos, salvo é óbvio, quando a irrupção de situações emergentes os exigiria e já por motivos indeclináveis, como os de evitar a periclitação da ordem, segurança ou saúde.

${ }^{193}$ ROCHA, 1999, p. 241. 
Em quarto lugar, descaberia contratar por esta via para cargo, função ou emprego de confiança, que isto seria a porta aberta para desmandos de toda espécie ${ }^{194}$.

Portanto, o pensamento aqui esposado é o de que a menção a conceitos jurídicos indeterminados pela lei pode ou não conduzir à atribuição de atuação discricionária à Administração Pública. A solução para a questão somente pode ser fornecida casuisticamente.

Com efeito, a técnica dos conceitos jurídicos indeterminados permite ao legislador decidir se a utilização de um conceito deve conduzir a uma certa liberdade do administrador ou se a lei deve regular exaustivamente o seu comportamento. O importante é, pois, que tal liberdade seja bem utilizada e não distorcida.

\subsubsection{A inexigibilidade constitucional de realização de concurso público, nos termos do artigo 37, II, da Constituição Federal}

Ao abordar a questão da inexigibilidade constitucional de realização de concurso público, nos termos do artigo 37, inciso II, da Constituição Federal, devem ser feitos alguns comentários. Preliminarmente, faz-se necessário estabelecer os seguintes pressupostos:

a) a contratação temporária deve (ou deveria) ser utilizada apenas excepcionalmente;

b) os servidores temporários não ocupam cargo ou emprego público;

c) os servidores temporários exercem função pública de caráter temporário.

Em razão das premissas acima, não se aplica a determinação constitucional do concurso público (artigo 37, II, da Constituição Federal), sendo utilizado, às vezes, um processo de seleção simplificada.

Para Márcio Barbosa Maia e Ronaldo Pinheiro de Queiroz, o concurso público é a forma mais democrática e legítima de buscar as melhores e mais bem qualificadas pessoas, entre as que participaram do certame, para ingressar no serviço público ${ }^{195}$.

O concurso permite que, nas mesmas condições, todos tenham oportunidades iguais para ingressar na Administração Pública, pois há a observância dos princípios da legalidade, da igualdade, da impessoalidade, da eficiência e da moralidade.

Ao definir concurso público, Cármen Lúcia Antunes Rocha afirma:

\footnotetext{
${ }^{194}$ MELLO, 1991, p. 82-83.

195 MAIA; QUEIROZ, 2007, p. 42.
} 
É o processo administrativo pelo qual se avalia o merecimento de candidatos à investidura em cargo ou emprego público, considerando-se suas características e a qualidade das funções que lhes são inerentes. É pelo concurso público que se concretiza a igualdade de oportunidades administrativas e a impessoalidade na seleção do servidor, impedindo-se tanto a pessoalidade quanto a imoralidade administrativa ${ }^{196}$.

Márcio Barbosa Maia e Ronaldo Pinheiro de Queiroz explicam a diferença entre concurso público e processo de seleção pública:

Não se pode confundir concurso público com processo de seleção pública. O concurso volta-se à seleção de pessoas para assumir cargos efetivos ou empregos públicos permanentes da União, dos Estados, do Distrito Federal, dos Municípios e das respectivas entidades autárquicas e fundacionais, das empresas públicas e sociedade de economia mista. $\mathrm{O}$ processo de seleção pública, à sua vez, aplica-se às pessoas jurídicas de direito público e às pessoas jurídicas de direito privado vinculadas aos princípios da Administração, ainda que não integrantes do Poder Público, relativamente às contratações de pessoal não sujeitas ao prévio concurso público $^{197}$.

Como exemplo de processo seletivo aplicado pelas entidades públicas no âmbito federal, é citada a contratação temporária para atender excepcional interesse público (artigo 37, IX, da Constituição Federal e artigo 3..$^{\circ}$ da Lei n. ${ }^{\circ}$ 8.745). Segundo Márcio Barbosa Maia e Ronaldo Pinheiro de Queiroz, as entidades privadas detentoras de privilégios estatais, ainda que não integrantes da administração indireta, mas que recebam expressivos recursos públicos e que mantenham vínculo jurídico com o Estado, estão sujeitas ao processo de seleção pública, em decorrência dos princípios da impessoalidade, da moralidade e da isonomia:

Do ponto de vista formal, assinala-se que o concurso público, diante de seu escopo, é dotado de inúmeras formalidades sacramentais, no afã de preservar a isonomia entre os administrados. O processo de seleção, à sua vez, embora sujeito aos princípios da Administração, pode ser simplificado (Lei n. ${ }^{\circ}$ 8.745/93, art. 3. ${ }^{\circ}$ ) e, em situações excepcionais, até mesmo dispensado. $\mathrm{O}$ concurso público é sempre de provas ou de provas e títulos, nos termos do art. 37, II, da CF/88. Em contrapartida, nada impede que o processo seletivo seja apenas de títulos, desde que pautado em critérios objetivos e razoáveis ${ }^{198}$.

Vale lembrar que não são todos os cargos que exigem o concurso público, apenas os cargos vitalícios e efetivos.

Estabelece o inciso II do artigo 37 que "a investidura em cargos ou emprego público depende de aprovação prévia em concurso público de provas e de provas e títulos,

\footnotetext{
${ }^{196}$ ROCHA, 1999, p. 201.

${ }^{197}$ MAIA; QUEIROZ, 2007, p. 15-16.

${ }^{198}$ MAIA; QUEIROZ, 2007, p. 17-18.
} 
de acordo com a natureza e a complexidade do cargo ou emprego, na forma prevista em lei, ressalvadas as nomeações para cargo em comissão declarado em lei de livre nomeação e exoneração". Está-se diante do princípio da obrigatoriedade do concurso público, o qual só poderá ser dispensado nas hipóteses adiante enumeradas.

1) Contratação temporária para atender a excepcional interesse público, nos termos do artigo 37, IX, da CF/88:

Como a CF, no art. 37, II, não exige concurso para o provimento de funções, a designação para estas, originária ou derivadamente, pode ocorrer de forma direta. É o que acontece, por exemplo, nos casos de "regime especial" (art. 37, IX, CF), disciplinado por lei, nas várias unidades federadas e nas designações para funções em comissão (como, na Administração Federal, a Lei n. ${ }^{\circ}$ 8.745, de 21/05/1993, alterada pela Lei n. ${ }^{\circ} 9.849$, de 26/10/1999). Entretanto, se a CF não exige, também não o proíbe, o que pode envolver a existência de normas de admissão para funções através de provas de seleção, como se vê, por exemplo, no Estado de São Paulo, com admissão de servidores para funções-atividade pela Lei n. ${ }^{\circ} 500 / 75^{199}$.

2) Nomeação para cargos em comissão e funções de confiança, nos termos do artigo 37, II, in fine, da Constituição Federal de 1988.

3) A situação mais comum da inexigibilidade de concurso é a nomeação para cargos em comissão (artigo 37, II e V, da Constituição Federal). Eles devem ser declarados em lei "de livre nomeação e exoneração". É dada (redação alterada pela EC n. ${ }^{\circ}$ 19/98) preferência aos ocupantes de cargos de carreira, nos casos, percentuais e condições estabelecidos em lei, destinando-se os cargos em comissão a atribuições de direção, chefia e assessoramento. As funções de confiança só devem ser exercidas por ocupantes de cargos efetivos.

4) Nomeação para determinados cargos vitalícios nas hipóteses constitucionalmente excepcionadas (caso dos Tribunais Superiores - quinto constitucional).

5) Promoção vertical.

6) Execução indireta de serviços licitados (terceirização).

7) Aproveitamento no serviço público de ex-combatente de guerra $^{200}$ :

8) Admissão excepcional de profissionais especializados nas empresas estatais exploradoras de atividade econômica.

\footnotetext{
199 ARAÚJO, 2014, p. 324, grifo do autor.

${ }^{200}$ O artigo 53 do Ato das Disposições Constitucionais Transitórias (ADCT), entre outros direitos, assegura, ao ex-combatente que tenha participado efetivamente (nos termos da Lei n. ${ }^{\circ}$ 5.315, de 12 de setembro de 1967) de operações bélicas durante a Segunda Guerra Mundial (1939/1945), o direito de "aproveitamento" no serviço público, sem a exigência de concurso e com estabilidade. É, como se vê, situação particular e excepcional, de difícil ou quase impossível ocorrência atualmente (ARAÚJO, 2014, p. 324).
} 
O que mais nos interessa é a dispensa do concurso público em razão da contratação temporária. A justificativa apresentada nesse caso é o fato de que o concurso público não seria viável, em razão das formalidades exigidas que demandariam bastante tempo, servindo como uma barreira ao rápido suprimento de pessoal perante contingências anormais no serviço público.

Assim, o artigo 37, IX, da Constituição Federal é destinado a casos em que a própria atividade a ser desempenhada é temporária, e aí não haveria viabilidade para o concurso público, "que se dispõe a prover cargos e empregos de natureza permanente, ou, mesmo que a atividade seja permanente, o excepcional interesse público demanda que se faça imediato suprimento de uma necessidade temporária, por não haver tempo hábil para realizar o concurso"201.

É importante ressaltar que, embora, em razão da necessidade temporária de excepcional interesse público, não haja tempo para a realização de um concurso público para selecionar pessoas, a contratação não é sem critério nenhum. Cita-se, no âmbito da União, o artigo $3 .^{\circ}$ da Lei n. ${ }^{\circ} 8.745 / 93$, que preceitua: “o recrutamento do pessoal a ser contratado, nos termos desta Lei, será feito mediante processo seletivo simplificado sujeito a ampla divulgação, inclusive através do Diário Oficial da União, prescindindo de concurso público".

Márcio Barbosa Maia e Ronaldo Pinheiro de Queiroz salientam que a Administração Pública não poderá deixar de observar a "finalidade e o escopo da contratação temporária, devendo imprimir ao processo de seleção um rito célere e compatível com o interesse público e, se for o caso, dispensar a sua adoção mediante contratação direta"202.

Assim, a Lei Federal n. ${ }^{\circ} 8.745 / 93$, em seu artigo $3 .^{\circ}, \S 1 .^{\circ}$, prevê hipóteses em que se prescinde de processo seletivo: em determinadas hipóteses excepcionalíssimas, a tutela do interesse público, por conta de risco iminente, revela-se incompatível com a deflagração do processo seletivo, como, por exemplo, nos casos de "calamidade pública, de emergência ambiental e de emergências em saúde pública".

Em outros casos, utiliza-se o seguinte critério: "notória capacidade técnica ou científica do profissional, mediante análise do curriculum vitae" ( $\S 2 .^{\circ}$ do artigo $3 .^{\circ}$ da Lei n. ${ }^{\circ}$ 8.745/93). Fazendo uma analogia com os casos de inexigibilidade de licitação, em que a

\footnotetext{
${ }^{201}$ MAIA; QUEIROZ, 2007, p. 43.
}

${ }^{202}$ MAIA; QUEIROZ, 2007, p. 49. 
competição é inviável, pode-se dizer que a competição nesse caso demonstra-se inviável, tornando inexigível o processo seletivo.

Frise-se: tudo deve ser devidamente motivado, justificado, devem ser indicados os motivos de fato e de direito do ato, a fim de dar validade ao procedimento e permitir o controle do ato.

Dependendo do caso concreto, da necessidade, da gravidade da situação, pode-se até contratar diretamente, mas desde que esse ato esteja devidamente motivado, fundamentado. O que não se admite é a contratação de qualquer pessoa sem o mínimo de qualificação para o exercício da função.

\subsubsection{Concretização do preceito constitucional no exercício da Administração Pública e sua submissão integral à axiologia constitucional}

A contratação por prazo determinado para atender a necessidade temporária de excepcional interesse público, nos moldes estabelecidos no artigo 37, IX, da Constituição Federal de 1988, deve estar em sintonia com os princípios que regem a vida da Administração Pública.

Inicialmente, é preciso esclarecer que os princípios são diferentes das regras, embora ambos pertençam a um mesmo gênero: normas jurídicas.

Robert Alexy afirma que tanto as regras como os princípios são normas porque ambos dizem o que deve ser. Ambos podem ser formulados com a ajuda das expressões deônticas básicas do mandamento, da permissão e da proibição. Os princípios, tal como as regras, são razões para juízos concretos de dever ser, ainda quando sejam razões de um tipo muito diferente. A distinção entre regras e princípios é, pois, uma distinção entre dois tipos de normas ${ }^{203}$.

Walter Claudius Rothenburg aponta aspectos em que os princípios se distinguem das demais normas jurídicas (as regras): no conteúdo (os princípios incorporando primeira e diretamente os valores ditos fundamentais, enquanto as regras deles se ocupam mediatamente, num segundo momento); na apresentação ou forma enunciativa (vaga, ampla, aberta dos princípios, contra uma maior especificidade das regras); na aplicação ou maneira de incidir (o princípio incidindo sempre, porém normalmente mediado por regras,

\footnotetext{
203 ALEXY, Robert. Teoría de los Derechos Fundamentales. Madrid: Centro de Estudios Políticos y Constitucionales, 2001, p. 83. Sobre a questão, ver: GRAU, Eros Roberto. A ordem econômica na Constituição de 1988: interpretação e crítica. 4. ed. São Paulo: Malheiros, 1998, p. 89-102; ROTHENBURG, Walter Claudius. Princípios constitucionais. Porto Alegre: Sergio Antonio Fabris, 1999, p. 13-49; SUNDFELD, Carlos Ari. Fundamentos de direito público. 3. ed. São Paulo: Malheiros, 1997, p. 135-136.
} 
sem excluir outros princípios concorrentes e sem desconsiderar outros princípios divergentes, que podem conjugar-se ou ser afastados apenas para o caso concreto; as regras incidindo direta e exclusivamente, constituindo aplicação integral - conquanto nunca exaustiva - e estrita dos princípios, e eliminando outras conflitantes); na funcionalidade ou utilidade (que é estruturante e de fundamentação nos princípios, enquanto as regras descem à regulação específica $)^{204}$.

Os princípios são como verdadeiras vigas mestras, autênticos alicerces que suportam todo o ordenamento jurídico. São eles que informam e formam a base de todo o sistema, dando-lhe a forma e os traços característicos primordiais a partir dos quais se estrutura o complexo de normas.

Princípio significa início, origem, fonte, começo. Os princípios representam as normas mais importantes, mais graduadas que as outras. São, por assim dizer, normas comportamentais de hierarquia elevada.

Da lição de Edmir Netto de Araújo, extrai-se:

A palavra princípio é daquelas que podem trazer a mesma grafia com significados variados, porém interligados: trata-se de vocábulo análogo, com os sentidos de origem, começo, postulado, base, teorema, dogma, e outros, sempre relacionados a ponto de partida, proposição básica ${ }^{205}$.

Segundo Cármen Lúcia Antunes Rocha, princípio é verbo, nele repousa a essência de uma ordem, seus parâmetros fundamentais e direcionadores do sistema ordenado ${ }^{206}$.

Explica Celso Antônio Bandeira de Mello:

Princípio [...] é, por definição, mandamento nuclear de um sistema, verdadeiro alicerce dele, disposição fundamental que se irradia sobre diferentes normas, compondo-lhes o espírito e servindo de critério para sua exata compreensão e inteligência, exatamente por definir a lógica e a racionalidade do sistema normativo, no que lhe confere a tônica e lhe dá sentido harmônico. É o conhecimento dos princípios que preside a intelecção das diferentes partes componentes do todo unitário que há por nome sistema jurídico positivo. Violar um princípio é muito mais grave que transgredir uma norma qualquer. A desatenção ao princípio implica ofensa não apenas a um específico mandamento obrigatório mas a todo o sistema de comandos. É a mais grave forma de ilegalidade ou inconstitucionalidade, conforme o escalão do princípio atingido, porque representa insurgência contra todo o sistema, subversão de seus valores fundamentais, contumélia irremissível a seu arcabouço lógico e corrosão de sua estrutura mestra ${ }^{207}$.

\footnotetext{
${ }^{204}$ ROTHENBURG, 1999, p. 81.

${ }^{205}$ ARAÚJO, 1990, p. 133.

${ }^{206}$ ROCHA, Cármen Lúcia Antunes. Princípios constitucionais da Administração Pública. Belo Horizonte: Del Rey, 1994, p. 21.

${ }^{207}$ MELLO, 2013, p. 974-975.
} 
Na mesma linha de pensamento, Roque Antônio Carrazza afirma:

o princípio jurídico é um enunciado lógico, implícito ou explícito, que, por sua grande generalidade, ocupa posição de preeminência nos vastos quadrantes do Direito e, por isso mesmo, vincula, de modo inexorável, o entendimento e a aplicação das normas jurídicas que com ele se conectam $^{208}$.

Sendo o embasamento do Direito de fundo principiológico, os princípios são os pilares fundamentais do sistema normativo, dado seu poder abstrato de atingir várias situações, viger por tempo indeterminado, servindo, assim, de base justificadora na solução de muitos conflitos.

Helenilson Pontes, ao ressaltar a importância dos princípios, destaca: “Os princípios jurídicos constituem a base da estrutura e do funcionamento do sistema jurídico. 'Pensar' o direito através dos princípios permite identificar a verdadeira riqueza do fenômeno jurídico, enquanto instância da realidade social marcada pelo dinamismo"209.

Os princípios são as normas mais importantes, possuem um forte conteúdo axiológico, sempre carregam um valor. Os princípios, por outro lado, formam a expressão máxima do Direito, visto que informam a estrutura das leis.

Em suma, o princípio é o fundamento do sistema, é a sua razão de ser, é a alma do ordenamento jurídico. Dessa forma, selecionaram-se alguns princípios diretamente relacionados à contratação temporária, o que não significa que, nos casos de contratação temporária, não devem ser observados os demais princípios.

\subsubsection{Princípio da continuidade do serviço público}

Um dos fundamentos para a contratação temporária é justamente o fato de que o serviço público não pode parar (hospital, universidade) ou deve ser prestado por mais pessoas (quando ocorre uma epidemia); portanto, em uma situação excepcional, contratamse pessoas para o exercício da função.

Na lição de Edmir Netto de Araújo, o princípio da continuidade do serviço público “é um princípio setorial, derivado do princípio geral da indisponibilidade do interesse público, que por sua vez decorre do princípio informativo da supremacia do interesse

${ }^{208}$ CARRAZZA, Roque Antônio. Curso de direito constitucional tributário. 11. ed. São Paulo: Malheiros, 1998 , p. 31.

209 PONTES, Helenilson Cunha. O princípio da proporcionalidade e o direito tributário. São Paulo: Dialética, 2000, p. 38. 
público"210. Esclarece o autor: "A continuidade do serviço público é um dos caracteres essenciais desse tipo de serviço, relacionado de maneira direta com a necessidade coletiva e também com a regularidade da prestação dos serviços que, não obstante similar, não é idêntico à continuidade" 211 .

Para Celso Antônio Bandeira de Mello, o princípio da continuidade do serviço público é um subprincípio ou princípio derivado, que decorre da obrigatoriedade do desempenho da atividade administrativa, a qual é oriunda do princípio da indisponibilidade para a administração dos interesses públicos. Acrescenta Bandeira de Mello:

Com efeito, uma vez que a Administração é curadora de determinados interesses que a lei define como públicos e considerando que a defesa, e prosseguimento deles, é, para ela, obrigatória, verdadeiro dever, a continuidade da atividade administrativa é princípio que se impõe e prevalece em quaisquer circunstâncias ${ }^{212}$.

Com efeito, Diogenes Gasparini, ao tratar do princípio da continuidade, ressalta: “Os serviços públicos não podem parar, porque não param os anseios da coletividade. Os desejos dos administrados são contínuos. Daí dizer-se que a atividade da Administração Pública é ininterrupta",213.

Está-se diante do princípio da continuidade do serviço público. O serviço público não pode parar. Por disso, criou-se uma válvula de escape (dispositivos) para fazer face a determinadas situações do cotidiano e permitir a continuidade do serviço. Eis a razão da criação ao artigo 37, IX, da Constituição Federal.

É importante ressaltar que o princípio da continuidade nem sempre significa atividade ininterrupta. A atividade deve ser apenas regular, em conformidade com a natureza e a forma de prestação. Como exemplo: realização de recenseamentos e outras pesquisas de natureza estatística efetuadas pela Fundação Instituto Brasileiro de Geografia e Estatística (IBGE) (no caso dos contratos temporários), serviço de coleta de lixo (realizado de três em três dias).

Entre as consequências que decorrem da paralisação dos serviços públicos, cita-se a "proibição" de greve nos serviços públicos, mas impõe-se o reconhecimento de que o Supremo Tribunal Federal deu um salto importante, tentando solucionar e tornar efetiva uma realidade, um direito consagrado na Constituição Federal, que é o direito de greve dos

\footnotetext{
${ }^{210}$ ARAÚJO, 2014, p. 134, grifos do autor.

211 ARAÚJO, 2014, p. 89, grifos do autor.

${ }^{212}$ MELLO, 2013, p. 84.

${ }^{213}$ GASPARINI, 2012, p. 71.
} 
servidores públicos, ao determinar a aplicação de um instituto de direito privado - a Lei n. ${ }^{\circ}$ $7.783 / 89$ - analogicamente ao servidor público civil ${ }^{214}$.

Já muito se escreveu sobre a greve do servidor público. Trata-se de um tema inquietante e não há soluções prontas e definitivas. $O$ direito à greve é garantido na Constituição Federal de 1988, porém, ainda não há lei específica sobre as condições e os limites de seu exercício pelos servidores públicos ${ }^{215}$.

A greve é um direito fundamental dos trabalhadores em geral e também dos servidores públicos. Certamente, não é um direito absoluto, porque encontra limites nos direitos de outras pessoas.

Em relação aos servidores públicos, ao estabelecer disposições gerais para a Administração Pública, a Constituição Federal consagrou o direito de greve em seu artigo 37 , VII.

${ }^{214}$ O Supremo Tribunal Federal já enfrentou tal questão em alguns mandados de injunção (MI) (por exemplo, MI n. ${ }^{\circ}$ 20, MI n. ${ }^{\circ} 438$, MI n. ${ }^{\circ} 485$ e MI n. ${ }^{\circ}$ 585). O Supremo Tribunal Federal reconheceu a mora do Congresso Nacional. Em alguns precedentes (em especial, no voto do Ministro Carlos Velloso, proferido no julgamento do MI n. ${ }^{\circ} 631 \mathrm{MS}$, relatado pelo Ministro Ilmar Galvão e publicado no Diário da Justiça (DJ) de 2 de agosto de 2002), aventou-se a possibilidade de aplicação aos servidores públicos civis da lei que disciplina os movimentos grevistas no âmbito do setor privado (Lei n. ${ }^{\circ}$ 7.783/89). Acontece que, apesar do reconhecimento da mora do Congresso Nacional pelo Supremo Tribunal Federal, até hoje não foi editada nenhuma lei específica para tratar da greve de servidores públicos civis. Com tal demora, as greves ocorrendo no país, os Tribunais passaram a entender efetivo o direito de greve dos servidores públicos (TRF. $4 .{ }^{a}$ Região. 4. ${ }^{\text {a }}$ Turma. Apelação Cível n. ${ }^{\circ}$ 2000.72.00.007531-6/SC. Juiz Federal Valdemar Capeletti. Julgamento: 22 ago. 2002). A situação não poderia continuar como estava, o problema colocava-se cada vez mais frequentemente, o que levou o Supremo Tribunal Federal a tomar uma atitude que pudesse dar uma resposta momentânea ao assunto. Assim, no MI n. ${ }^{\circ}$ 670/ES, no MI n. ${ }^{\circ}$ 708/DF e no MI n. ${ }^{\circ}$ 712/PA, o Supremo Tribunal Federal alterou seu posicionamento sobre o direito de greve do servidor público, segundo o qual, por meio de mandado de injunção, só se poderia notificar o Congresso Nacional de sua mora. Alguma medida deveria ser tomada. Então, o plenário do Supremo Tribunal Federal concluiu o julgamento dos referidos mandados de injunção em 25 de outubro de 2007; por unanimidade, decidiu declarar a omissão legislativa quanto ao dever constitucional de editar lei que regulamente o exercício do direito de greve no setor público e, por maioria, aplicar ao setor, no que couber, a lei de greve vigente no setor privado (Lei n. ${ }^{\circ}$ 7.783/89). Houve divergência parcial dos Ministros Ricardo Lewandowski, Joaquim Barbosa e Marco Aurélio, que estabeleciam condições para a utilização da lei de greve, considerando a especificidade do setor público, já que a norma foi feita visando ao setor privado, e limitavam a decisão às categorias representadas pelos sindicatos requerentes, na tradição de ter o mandado de injunção efeitos apenas inter partes. Ocorre que o Supremo Tribunal Federal foi mais além, determinando as regras aplicáveis a futuros casos semelhantes, ou seja, a aplicação da Lei n. ${ }^{\circ} 7.783 / 89$, sempre que se tratar de greve de servidores públicos. As greves continuaram, e o Supremo Tribunal Federal começou a restringir a amplitude do entendimento quanto ao direito de greve. Na apreciação da Reclamação n. ${ }^{\circ}$ 6568, relatada pelo Ministro Eros Grau (julgamento em 21 de maio de 2009, publicado no Diário da Justiça Eletrônico (Dje) n. ${ }^{\circ} 181$ ), foi decidido que o direito de greve deve ser restringido para algumas categorias que exercem atividades relacionadas à manutenção da ordem pública. Com relação especificamente aos policiais civis, o Supremo Tribunal Federal considerou as atividades desenvolvidas por eles "análogas, para esse efeito, às dos militares, em relação aos quais a Constituição expressamente proíbe a greve". No Recurso Extraordinário n. ${ }^{\circ}$ 456.530-ED (Segunda Turma. Rel. Min. Joaquim Barbosa. Julgamento: 23 nov. 2010. DJe, 1. ${ }^{\circ}$ fev. 2011), o Supremo Tribunal Federal entendeu possível, em caso de greve de servidor, o desconto dos dias parados, sem prejuízo da possibilidade de composição em benefício dos grevistas. No mesmo sentido, RE n. ${ }^{\circ}$ 399.338-AgR (Primeira Turma. Rel. Min. Cármen Lúcia. Julgamento: 1. e․ 2011. DJe, 24 fev. 2011).

${ }^{215}$ BASTOS, Aline Maria Dias. A Lei de Greve aplicada ao servidor público. In: DI PIETRO, Maria Sylvia Zanella (Org.). Direito privado administrativo. São Paulo: Atlas, 2013, p. 50. 
O artigo 37, incisos VI e VII, da Constituição Federal (o último com redação alterada pela Emenda Constitucional n. ${ }^{\circ}$ 19) garante ao servidor público, respectivamente, o direito à livre associação sindical e o direito de greve, que "será exercido nos termos e nos limites definidos em lei específica". O primeiro é autoaplicável; o segundo depende de lei.

Entende-se que dadas as diferenças entre os setores público e privado, as peculiaridades e regras próprias do serviço público, em especial a exigência de continuidade, a lei de greve não pode ser aplicada ao setor público da mesma forma em que é aplicada à atividade privada.

A regulamentação do direito de greve dos servidores públicos deve ser feita com bastante cuidado, a regulamentação não poderá diminuí-lo de modo a negar tal direito, mas a lei deve estabelecer os reais critérios para garantir o exercício do direito de greve, respeitando os direitos da sociedade.

A questão é saber se, em caso de greve nos serviços públicos, poderia haver a contratação temporária. A resposta não é pacífica e deve ser analisada de acordo com o caso concreto, pois a greve pode ocorrer por vários motivos. O mais comum é a reivindicação de aumento salarial, mas a greve pode ser por questões de segurança, por falta de condições de trabalho.

Não resta dúvida de que cabe ao Poder Legislativo estabelecer os parâmetros da greve dos servidores públicos, sem esquecer que deve haver uma sintonia e uma compatibilidade entre o exercício do direito de greve e as peculiaridades aplicadas ao serviço público ${ }^{216}$.

\subsubsection{Princípio da moralidade}

O princípio da moralidade, consagrado no caput do artigo 37 da Lei Maior, não seria propriamente um princípio jurídico, mas da moral ou ética. Ocorre que a Constituição Federal, de certa forma, "juridicizou" tal princípio, sendo, assim, de observância obrigatória para a Administração Pública.

A aplicação do artigo 37, IX, da Constituição Federal requer que seja observado o princípio da moralidade administrativa com bastante rigor, o que, infelizmente, não tem sido adotado nos casos de contratação temporária.

${ }^{216}$ BASTOS, 2013, p. 50-64. 
Nesse sentido, importantes são os ensinamentos de Maria Sylvia Zanella Di Pietro sobre a moral administrativa, que "corresponde àquele tipo de comportamento que os administrados esperam da Administração Pública para a consecução de fins de interesse coletivo, segundo uma comunidade moral de valores, expressos por meio de standards, modelos ou pautas de conduta" 217.

A moralidade significa a ética da conduta administrativa; a pauta de valores morais a que a Administração Pública está subordinada.

Diogo de Figueiredo Moreira Neto considera o resultado, na moral administrativa, desvinculadamente da intenção de produzi-lo, pois está-se diante de um conceito finalisticamente orientado. Acrescenta:

Não se quer julgar, aqui, a atitude de um agente administrativo, mas sua conduta. A atitude não conduz a um bom resultado administrativo, capaz de satisfazer a finalidade institucional da Administração Pública; mas a conduta, sim, produz resultados moral-administrativamente sadios ou viciados. Ora, esse bom resultado, objetivamente considerado, a que moralmente deve tender a Administração Pública, só pode ser o que concorra para a realização da boa administração, inegavelmente o que satisfaz o direcionamento aos interesses públicos, o que vem a ser seu fim institucional ${ }^{218}$.

Manoel de Oliveira Franco Sobrinho ressalta que estará fora da moral comum social aquele ato administrativo que, na sua eficácia, infringe a motivação, escapa da finalidade e não se apoia na exação ${ }^{219}$.

Com relação ao princípio da moralidade, Maria Sylvia Zanella Di Pietro esclarece:

Não é preciso penetrar na intenção do agente, porque do próprio objeto resulta a imoralidade. Isto ocorre quando o conteúdo de determinado ato contrariar o senso comum de honestidade, retidão, equilíbrio, justiça, respeito à dignidade do ser humano, à boa-fé, ao trabalho, à ética das instituições. A moralidade exige proporcionalidade entre os meios e os fins a atingir; entre os sacrifícios à coletividade e os benefícios por ela auferidos; entre as vantagens usufruídas pelas autoridades públicas e os encargos impostos à maioria dos cidadãos. Por isso mesmo, a imoralidade salta aos olhos quando a Administração Pública é pródiga em despesas legais, porém inúteis, como propaganda ou mordomia, quando a população precisa de assistência médica, alimentação, moradia, segurança, educação, isso sem falar no mínimo indispensável à existência digna ${ }^{220}$.

${ }^{217}$ DI PIETRO, Maria Sylvia Zanella. Discricionariedade administrativa na Constituição de 1988. 2. ed. São Paulo: Atlas, 2001, p. 162, grifo da autora.

${ }^{218}$ MOREIRA NETO, Diogo de Figueiredo. Moralidade administrativa: do conceito à efetivação. Revista de Direito Administrativo, Rio de Janeiro, n. 190, out./dez. 1992, p. 7-8, grifos do autor.

${ }^{219}$ FRANCO SOBRINHO, Manoel de Oliveira. Do princípio da moralidade administrativa. Revista de Direito Administrativo, Rio de Janeiro, n. 190, out./dez. 1992, p. 248.

${ }^{220}$ DI PIETRO, 2001, p. 154-155. 
A moralidade administrativa refere-se a um tipo de moral não comum, mas jurídica $^{221}$, conforme a observância de outros princípios e, primordialmente, na lição de Edmir Netto de Araújo, do dever de lealdade às instituições: “O agente verificará sobre o legal ou ilegal, adotando obrigatoriamente a primeira postura; sobre o oportuno ou conveniente decidirá, dentro dos quadros da ordem jurídica; mas também sobre o honesto ou desonesto, pois nem tudo o que é legal, formalmente, é honesto ou moral"222.

Toshio Mukai defende que a moralidade administrativa difere da moralidade comum e ressalta:

Já a moralidade administrativa difere da moralidade comum porque ela busca e significa tão-só que o agente público atue na condição de um bom administrador, como alguém que, gerindo recursos alheios, o faz ciente de que não são seus, e, portanto, atuando com eficiência, zelo, parcimônia, honestidade e, sobretudo, com a observância da boa-fé, enfim, o princípio da moralidade administrativa requer que o administrador público, na prática de cada ato de sua alçada e competência, saiba discernir entre aquilo que é do bem daquilo que é do mal e, além disso, tenha no seu agir a preocupação constante do bom administrador, aplicando a lei corretamente, no sentido sempre da satisfação do interesse público, fim último do Estado $^{223}$.

Assim, procurou-se enfatizar o direito público subjetivo de todo o cidadão ao trato ético da coisa pública. $\mathrm{O}$ cidadão é, portanto, titular do direito à administração honesta $\mathrm{e}$ moral. Compreendem-se em seu âmbito, como é evidente, os chamados princípios da lealdade e da boa-fé, devendo a Administração proceder em relação aos administrados com sinceridade e lhaneza.

Ressalte-se que a Lei n. ${ }^{\circ}$ 9.784/99, em seu artigo 2. ${ }^{\circ}$, incluiu o princípio da moralidade entre os de observância obrigatória pela Administração Pública, enfatizando o inciso IV do mesmo artigo que, nos processos administrativos, deve ser observado o critério de "atuação segundo padrões éticos de probidade, decoro e boa-fé".

Maria Sylvia Zanella Di Pietro adverte: o princípio deve ser observado não apenas pelo administrador, mas também pelo particular que se relaciona com a Administração Pública:

Em resumo, sempre que em matéria administrativa se verificar que o comportamento da Administração ou do administrado que com ela se relaciona juridicamente, embora em consonância com a lei, ofende a moral, os bons costumes, as regras de boa administração, os princípios de

\footnotetext{
${ }^{221}$ HAURIOU, Maurice. Précis de droit administratif et de droit public. Paris: Sirey, 1927, p. 376.

${ }^{222}$ ARAÚJO, 1990, p. 140.

223 MUKAI, Toshio. Da aplicabilidade do princípio da moralidade administrativa e do seu controle jurisdicional. Boletim de Direito Administrativo, São Paulo, v. 10, n. 2, fev. 1994, p. 88.
} 
justiça e de equiidade, a ideia comum de honestidade, estará havendo ofensa ao princípio da moralidade administrativa ${ }^{224}$.

O princípio da moralidade tornou-se pressuposto de validade dos atos da Administração, com ênfase no dever de probidade do administrador público, que deve agir com honestidade de propósitos, imparcialidade e com os olhos voltados para o interesse público.

O controle jurisdicional da moralidade administrativa está consagrado pelo preceito constitucional regulador da ação popular (artigo 5. ${ }^{\circ}$, LXXIII, da Constituição Federal) que conferiu legitimidade a qualquer cidadão para propô-la, visando a anular ato lesivo à moralidade administrativa -, pela ação civil pública (Lei n. ${ }^{\circ}$ 7.347, de 24 de julho de 1985) e pela lei que mais especificamente reprime os atos de improbidade do agente público (Lei n. ${ }^{\circ} 8.429$, de 2 de junho de 1992).

Com relação aos servidores públicos, os atos de improbidade administrativa “importarão a suspensão dos direitos políticos, a perda da função pública, a indisponibilidade dos bens e o ressarcimento ao erário, na forma e gradação previstas em lei, sem prejuízo da ação penal cabível” (artigo 37, § 4. ${ }^{\circ}$, da Constituição Federal).

De igual modo, o princípio da moralidade deverá desempenhar o papel de limite nos casos de contratação temporária. O agente público deve ser um bom administrador, pois está gerindo recursos alheios, devendo agir com eficiência, zelo, parcimônia, honestidade e, sobretudo, com a observância da boa-fé, ou seja, fazendo com que as contratações temporárias obedeçam ao princípio da moralidade administrativa, buscando sempre o interesse público.

Portanto, o princípio da moralidade nada mais é do que atender ao interesse público com legalidade ética.

\subsubsection{Princípio da impessoalidade}

Na lição de Hely Lopes Meirelles, o princípio da impessoalidade tem como fundamento o princípio da finalidade: “o qual impõe ao administrador público que só pratique o ato para o seu fim legal. E o fim legal é unicamente aquele que a norma de Direito indica expressa ou virtualmente como objetivo do ato, de forma impessoal",225.

\footnotetext{
${ }^{224}$ DI PIETRO, 2013, p. 79.

${ }^{225}$ MEIRELLES, 2012, p. 93, grifos do autor.
} 
Para Maria Sylvia Zanella Di Pietro, exigir impessoalidade da Administração "tanto pode significar que esse atributo deve ser observado tanto em relação aos administrados como à própria Administração" ${ }^{226}$. Segundo a autora, no primeiro caso, o princípio da impessoalidade relaciona-se com a finalidade pública; no segundo caso, baseia-se na teoria da imputação ou do órgão.

Celso Antônio Bandeira de Mello entende que o princípio da impessoalidade não é senão o próprio princípio da igualdade ou isonomia:

Nele se traduz a ideia de que a Administração tem que tratar a todos os administrados sem discriminações, benéficas ou detrimentosas. Nem favoritismo nem perseguições são toleráveis. Simpatias ou animosidades pessoais, políticas ou ideológicas não podem interferir na atuação administrativa e muito menos interesses sectários, de facções ou grupos de qualquer espécie ${ }^{227}$.

Segundo Lúcia Valle Figueiredo impessoalidade é, por conseguinte, imparcialidade, julgamento desapaixonado ${ }^{228}$.

Bem explica Irene Patrícia Nohara, após estudar os fundamentos da impessoalidade:

$\mathrm{Na}$ realidade, todos os fundamentos (finalidade, teoria do órgão, imparcialidade e igualdade) são indissociáveis, pois a consecução dos fins de interesse público deve guiar a atividade administrativa, na qual a manifestação da vontade estatal, pela teoria do órgão, não pode ser confundida com a vontade subjetiva do agente público, que deve agir de forma imparcial, tratando a todos sem discriminações arbitrárias. Contudo para que tal objetivo seja de fato alcançado, é necessário que os agentes públicos sejam envolvidos na permanente tarefa ética de pautarem suas ações em uma consciência moral que reconheça as necessidades coletivas, transcendendo àquelas de índole egoística ou individual $^{229}$.

No presente estudo, deve-se entender o princípio da impessoalidade no sentido de que a Administração não pode agir motivada por interesses particulares, interesses políticos, de grupos, por animosidades ou simpatias pessoais, políticas, ideológicas etc., implicando sempre regra de agir objetiva para o administrador, de forma a atender ao fim legal do interesse público.

O princípio da impessoalidade exerce um papel importante na seleção das pessoas que serão contratadas temporariamente.

\footnotetext{
${ }^{226}$ DI PIETRO, 2013, p. 68.

${ }^{227}$ MELLO, 2013, p. 117.

${ }^{228}$ FIGUEIREDO, 2008, p. 64.

${ }^{229}$ NOHARA, Irene Patrícia. Direito administrativo. 3. ed. São Paulo: Atlas, 2013. p. 72.
} 
2.6.6.4 Princípio da razoabilidade e da proporcionalidade

Reconhece-se que a razoabilidade é, também, um conceito fluido, indeterminado, que contém uma certa subjetividade, pois o que é razoável para alguns pode não sê-lo para outros. Além disso, ainda que se suponha que algo seja razoável para o homem médio, a objetividade desejável para instituir a razoabilidade como um princípio não ocorre.

Contudo, é possível constatar que o princípio da razoabilidade indica a prudência, a sensatez, o ponderável, o justo, o equilibrado, o adequado, o moderado, o comedido, o aceitável, o regular, o que não choca, o legítimo, o bom senso, o equilíbrio nas condutas judiciais e administrativas.

Com muita propriedade, ao estudar os princípios da razoabilidade e da proporcionalidade, José Roberto Pimenta Oliveira afirma:

No exercício da administração pública, agir com razoabilidade significa fundamentalmente, levar a cabo a execução da Constituição e da lei mediante uma atenta consideração à realização possível e exigível, em face das condições fáticas e jurídicas enfrentadas por cada intervenção administrativa, dos princípios, valores, interesses, bens e direitos, de índole pública individual, difusa ou coletiva, envolvidos na espécie e aos quais o ordenamento jurídico, como um todo, dedica uma proteção ${ }^{230}$.

Edmir Netto de Araújo entende que, na realidade, o princípio da razoabilidade traduz a congruência lógica entre o fato (o motivo) e a atuação concreta da Administração 231 .

Existem duas abordagens do princípio da razoabilidade: a primeira, influenciada pela jurisprudência norte-americana, liga o princípio da razoabilidade ao do devido processo legal e ao da isonomia; a segunda, por sua vez, seguindo a linha do direito francês, espanhol e argentino, identifica a razoabilidade com o princípio da proporcionalidade entre os meios e os fins.

O princípio da razoabilidade é um aliado especial para delimitar o âmbito da discricionariedade administrativa, possibilitando ao Poder Judiciário aumentar a esfera de apreciação do ato administrativo. É utilizado como um limite à discrição na avaliação dos motivos (é importante conhecer os motivos que conduziram a Administração a adotar determinada medida) e na escolha do objeto, de forma a atingir a finalidade pública.

\footnotetext{
${ }^{230}$ OLIVEIRA, José Roberto Pimenta. Os princípios da razoabilidade e da proporcionalidade no direito administrativo brasileiro. São Paulo: Malheiros, 2006, p. 545.

${ }^{231}$ ARAÚJO, 2014, p. 84.
} 
Cármen Lúcia Antunes Rocha afirma que a razoabilidade administrativa "é elemento que dota de legitimidade a conduta do administrador público, por ser o que objetiva as razões de seu comportamento e demonstra, então, a justeza da conduta e a sua adequação ao quanto prescrito e previsto no sistema de direito"232.

No tocante à razoabilidade, Celso Antônio Bandeira de Mello acentua:

A Administração, ao atuar no exercício de discrição, terá de obedecer a critérios aceitáveis do ponto de vista racional, em sintonia com o senso normal de pessoas equilibradas e respeitosas das finalidades que presidiram a outorga da competência exercida. Vale dizer: pretende-se colocar em claro que não serão apenas inconvenientes, mas também ilegítimas - e, portanto, jurisdicionalmente invalidáveis -, as condutas desarrazoadas, bizarras, incoerentes ou praticadas com desconsideração às situações e circunstâncias que seriam atendidas por quem tivesse atributos normais de prudência, sensatez e disposição de acatamento às finalidades da lei atributiva da discrição manejada ${ }^{233^{3}}$.

Integra a ideia de razoabilidade a denominada proporcionalidade. Logo, a proporcionalidade é um dos aspectos da razoabilidade, conforme os ensinamentos de Maria Sylvia Zanella Di Pietro:

O princípio da razoabilidade, entre outras coisas, exige proporcionalidade entre os meios de que se utilize a Administração e os fins que ela tem que alcançar. E essa proporcionalidade deve ser medida não pelos critérios pessoais do administrador, mas segundo padrões comuns na sociedade em que vive; e não pode ser medida diante dos termos frios da lei, mas diante do caso concreto. Com efeito, embora a norma legal deixe um espaço livre para a decisão administrativa, segundo critérios de oportunidade e conveniência, essa liberdade às vezes se reduz no caso concreto, onde os fatos podem apontar para o administrador a melhor solução (cf. Celso Antônio Bandeira de Mello, in RDP 65/27). Se a decisão é manifestamente inadequada para alcançar a finalidade legal, a Administração terá exorbitado dos limites da discricionariedade e o Poder Judiciário poderá corrigir a ilegalidade ${ }^{234}$.

Paulo Bonavides, ao tratar do princípio da proporcionalidade, afirma que esse princípio "protege o cidadão contra os excessos do Estado e serve de escudo à defesa dos direitos e liberdades constitucionais", e completa: "O princípio da proporcionalidade é hoje axioma do direito constitucional, corolário da constitucionalidade e cânone do estado de direito, bem como regra que tolhe toda a ação ilimitada do poder do Estado no quadro da juridicidade de cada sistema legítimo de autoridade" ${ }^{235}$.

\footnotetext{
${ }^{232}$ ROCHA, 1994, p. 112.

${ }^{233}$ MELLO, 2013, p. 111.

${ }^{234}$ DI PIETRO, 2013, p. 81, grifos da autora.

${ }^{235}$ BONAVIDES, Paulo. Curso de direito constitucional. 5. ed. São Paulo: Malheiros, 1994, p. 397.
} 
Segundo a doutrina alemã, a proporcionalidade pressupõe três elementos: a adequação, a necessidade e a proporcionalidade em sentido estrito.

Transpondo-se a questão para o Direito Administrativo, deve haver adequação da medida restritiva adotada ao fim a que se propõe. Portanto, diante do caso concreto, analisa-se se o meio utilizado tem aptidão jurídica para atingir, adequadamente, de forma idônea, o resultado almejado.

Suzana de Toledo Barros observa que a possibilidade de controle judicial sobre uma relação de causalidade (entre a medida restritiva adotada e o fim a que se destina), por si só, já abala a ideia do legislador onipotente, capaz de criar situações desarrazoadas, incoerentes ou até mesmo bizarras ${ }^{236}$.

Quanto à necessidade ou exigibilidade da conduta administrativa, investiga-se sua adoção como indispensável à tutela do bem jurídico curado pela Administração; impõe-se a verificação da inexistência de meio menos gravoso para alcançar o fim visado.

Em relação à proporcionalidade em sentido estrito, examina-se a justa medida da prescrição veiculada no ato administrativo. É a ponderação entre o ônus e o benefício trazido para constatar se é justificável a interferência na esfera dos direitos dos cidadãos. Para Suzana de Toledo Barros, a proporcionalidade em sentido estrito atua complementando a adequação e a necessidade, de forma a indicar se o meio utilizado encontra-se em razoável proporção com o fim a ser alcançado ${ }^{237}$.

Extrai-se do princípio da razoabilidade a proibição de condutas administrativas desarrazoadas, exorbitantes, disparatadas.

No direito norte-americano, o devido processo legal aplica-se, integralmente, à atividade administrativa das agencies. As Cortes permitem que as agências considerem a discricionariedade em todos os aspectos de sua decisão, nos fatos encontrados, na interpretação de estatutos e na seleção de procedimentos.

$\mathrm{O}$ princípio da razoabilidade foi o que teve o mais rápido e amplo curso na interpretação constitucional brasileira. A interpretação, hoje em dia, é fundada no princípio da razoabilidade: adequação, meio, fim, necessidade da medida, com a consequente vedação do excesso ${ }^{238}$.

\footnotetext{
${ }^{236}$ BARROS, Suzana de Toledo. O princípio da proporcionalidade e o controle de constitucionalidade das leis restritivas de direitos fundamentais. 2. ed. Brasília, DF: Brasília Jurídica, 2000, p. 77. ${ }^{237}$ BARROS, 2000, p. 83.

${ }^{238} \mathrm{O}$ excesso de poder verifica-se quando a autoridade administrativa, embora tenha competência para realizar o ato, realiza-o ultrapassando essa mesma competência administrativa que lhe foi outorgada pela lei.
} 
Verifica-se que aos poucos o exame da razoabilidade e da proporcionalidade dos atos discricionários adquire espaço no controle jurisdicional, especialmente quando se trata de sanções administrativas e do exercício do poder de polícia.

Nesse sentido, são válidas as observações de José Roberto Pimenta Oliveira:

$\mathrm{Na}$ atividade ordenadora e sancionatória da Administração Pública, os princípios da razoabilidade e da proporcionalidade avultam como mecanismos básicos de contenção de inconstitucionalidades e/ou ilegalidades, impondo o devido nível de equilíbrio axiológico na estruturação das relações jurídico-administrativas e no correspondente desempenho dos deveres-poderes outorgados à cura administrativa ${ }^{239}$.

Helenilson Cunha Pontes aponta a necessidade da utilização do princípio da proporcionalidade nas ações sancionatórias:

A imposição de uma sanção consiste em uma limitação à esfera juridicamente protegida (prima facie) do infrator, quase sempre concernente à sua liberdade e propriedade; daí porque o juízo de compatibilidade da lei que institui uma sanção em face do princípio da proporcionalidade supera a mera consideração da adequação (relação meio-fim) entre a pena imposta e o objetivo visado pela regra inobservada, e deve, sempre (e esta talvez seja a maior contribuição do princípio da proporcionalidade para o controle do poder e para a afirmação das liberdades individuais), considerar o grau de limitação sofrido pela esfera jurídica do infrator ${ }^{240}$.

Celso Antônio Bandeira de Mello, sobre o princípio da proporcionalidade, ressalta:

Este princípio enuncia a ideia - singela, aliás, conquanto frequentemente desconsiderada - de que as competências administrativas só podem ser validamente exercidas na extensão e intensidade proporcionais ao que seja realmente demandado para cumprimento da finalidade de interesse público a que estão atreladas. Segue-se que os atos cujos conteúdos ultrapassem o necessário para alcançar o objetivo que justifica o uso da competência ficam maculados de ilegitimidade, porquanto desbordam do âmbito da competência; ou seja, superam os limites que naquele caso lhes corresponderiam $^{241}$.

Segundo Juan Francisco Linares, a exigência de razoabilidade é inerente à própria legalidade, que não só impõe "aos órgãos administrativos um agir de acordo com ou segundo a lei, mas um atuar razoável". Mais adiante acentua o referido autor que "impõe ao órgão o dever jurídico de ditar atos não apenas com determinados requisitos de forma, procedimento e conteúdo expressos em lei, mas sobretudo requisitos axiológicos" 242 .

\footnotetext{
${ }^{239}$ OLIVEIRA, 2006, p. 547.

${ }^{240}$ PONTES, 2000, p. 137.

${ }^{241}$ MELLO, 2013, p. 113, grifos do autor.

${ }^{242}$ LINARES, Juan Francisco. Poder discrecional administrativo. Buenos Aires: Abeledo-Perrot, 1958, p. 115 .
} 
Há de se dizer que a Lei n. ${ }^{\circ}$ 9.784/99, em seu artigo $2 .^{\circ}$, faz referência aos princípios da razoabilidade e da proporcionalidade ${ }^{243}$.

Márcio Barbosa Maia e Ronaldo Pinheiro de Queiroz ressaltam que o limite do prazo do contrato temporário deve atender aos princípios da proporcionalidade e da razoabilidade:

\begin{abstract}
Entendemos que os contratos que admitem sucessivas prorrogações de sua vigência, acarretando prazos demasiadamente longos de contratação, desvirtuam o instituto e descortinam o desvio de finalidade do Poder Público, malferindo o princípio constitucional do concurso público. Nesse sentido, cumpre citar o excerto colhido do aresto do Tribunal Regional Federal da 1. ${ }^{\mathrm{a}}$ Região, nestes termos: "não se pode ter como temporária necessidade que se estende por quatro anos, constituindo o ato clara burla à lei e ao concurso público [...]" (2. ${ }^{\text {a }}$ Turma, Des. Assusete Magalhães, DJU, 13-3-1995, p. 12779) ${ }^{244}$.
\end{abstract}

Como exemplo de tal abuso, os referidos autores apontam o artigo 26 da Lei n. ${ }^{\circ}$ 9.986/2000, que dispõe sobre a gestão de recursos humanos das agências reguladoras, que admite a prorrogação dos contratos temporários dessas autarquias em regime especial por mais 24 meses, "além daqueles na legislação vigente, a partir do vencimento de cada contrato de trabalho".

Pode-se dizer que, somente em cotejo com os demais princípios constitucionais, com a observância da realidade e da situação concreta em que ocorre a atuação administrativa, é possível determinar a razoabilidade e a proporcionalidade, em conformidade com os standards ou padrões de comportamento vigentes na sociedade na ocasião de sua prática.

Assim, o limite do prazo do contrato temporário deve atender aos princípios da proporcionalidade e da razoabilidade. Na aplicação das sanções administrativas, deverão ser observados o princípio da razoabilidade e o da proporcionalidade, que adquirem um importante espaço em matéria de controle jurisdicional.

\title{
2.6.6.5 Princípio da motivação
}

Motivar é expor as razões de fato e de direito que autorizam ou determinam a prática de um ato jurídico. É por intermédio da motivação que se verifica a legalidade do

\footnotetext{
${ }^{243}$ A Constituição do Estado de São Paulo, promulgada em 1989, no artigo 111, inclui entre os princípios a que se sujeita a Administração Pública o da razoabilidade.

${ }^{244}$ MAIA; QUEIROZ, 2007, p. 44-45.
} 
ato. A motivação é uma garantia de legalidade, tanto para o interessado quanto para a própria Administração Pública.

Atualmente, discute-se o que a motivação deve abranger: apenas a explicitação dos motivos do ato ou também a exposição da finalidade do ato. Celso Antônio Bandeira de Mello afirma:

[O princípio da motivação] implica para a Administração o dever de justificar seus atos, apontando-lhes os fundamentos de direito e de fato, assim como a correlação lógica entre os eventos e situações que deu por existentes e a providência tomada, nos casos em que este último aclaramento seja necessário para aferir-se a consonância da conduta administrativa com a lei que lhe serviu de arrimo $^{245}$.

A Lei Federal n. ${ }^{\circ}$ 9.784, de 29 de janeiro de 1999, que regula o processo administrativo no âmbito da Administração Federal, em seu artigo 50, dispõe:

Os atos administrativos deverão ser motivados, com indicação dos fatos e dos fundamentos jurídicos, quando:

I - neguem, limitem ou afetem direitos ou interesses;

II - imponham ou agravem deveres, encargos ou sanções;

III - decidam processos administrativos de concurso ou seleção pública;

IV - dispensem ou declarem a inexigibilidade de processo licitatório;

$\mathrm{V}$ - decidam recursos administrativos;

VI - decorram de reexame de ofício;

VII - deixem de aplicar jurisprudência firmada sobre a questão ou discrepem de pareceres, laudos, propostas e relatórios oficiais;

VIII - importem anulação, revogação, suspensão ou convalidação de ato administrativo.

Diogenes Gasparini ressalta o que é necessário para haver a contratação temporária:

Para a contratação, deve a Administração Pública promover a devida justificativa, com a correta descrição da situação de anormalidade e das razões que a tornam imprescindível e que caracterizam o excepcional interesse público. O descumprimento dessa obrigação pode levar à nulidade da contratação e à responsabilização da autoridade que a ensejou, por configurar inobservância ao inciso II do art. 37 da Constituição Federal, conforme preceituado no $\S 2 .^{\circ}$ dessa regra, sem prejuízo da competente ação popular, que pode ser impetrada por qualquer cidadão, para ver extinta a contratação e compelida a autoridade responsável a compor os danos que seu comportamento causou ao erário público, consoante previsto no inciso I do art. $4 .^{\circ}$ da Lei federal n. $^{\circ}$ $4.717 / 65^{246}$.

Existe, também, a teoria dos motivos determinantes, exposta por Jèze, segundo a qual a Administração Pública fica vinculada aos motivos aduzidos no ato administrativo, isto é, os motivos apresentados pelo agente administrativo como justificativas do ato associam-se a sua validade. O motivo determinante deve ser não somente lícito, mas

${ }^{245}$ MELLO, 2013, p. 115.

${ }^{246}$ GASPARINI, 2012, p. 215. 
também adequado ao ato, como complemento da investigação da competência dos agentes públicos $^{247}$.

Edmir Netto de Araújo, com muita propriedade, afirma que "é este o sentido da expressão 'motivos determinantes', que, segundo a respectiva teoria, integram, como fatos e pressupostos que serviram de suporte à decisão do agente, a validade intrínseca do ato" $^{, 248}$.

Antônio Carlos de Araújo Cintra, ao examinar a teoria dos motivos determinantes, assinala que ela assumiu proporções demasiadamente amplas, abrangendo e superando a teoria do desvio de poder, vinculando-se ao problema da competência ${ }^{249}$.

Reportando-se à teoria dos motivos determinantes, Maria Sylvia Zanella Di Pietro ressalta que "a validade do ato se vincula aos motivos indicados como seu fundamento, de tal modo que, se inexistentes ou falsos, implicam a sua nulidade. [...] Quando a Administração motiva o ato, mesmo que a lei não exija a motivação, ele só será válido se os motivos forem verdadeiros" $" 250$.

A autora ilustra essa questão com o seguinte exemplo: se, para praticar a exoneração ad nutum, para a qual a lei não define o motivo, a Administração alegar que o fez por falta de verba e depois nomear outro funcionário para a mesma vaga, o ato será nulo por vício quanto ao motivo.

A teoria dos motivos determinantes foi acolhida pela legislação pátria, pois o artigo 2. ${ }^{\circ}$ caput, alínea “d”, da Lei de Ação Popular (Lei n. ${ }^{\circ}$ 4.717/65) estabeleceu que nulo é o ato administrativo lesivo ao patrimônio público, quando inexistem os motivos determinantes do ato, e quando a matéria de fato ou de direito em que se fundamenta o ato é materialmente inexistente ou juridicamente inadequada ao resultado obtido.

Celso Antônio Bandeira de Mello ensina com muita propriedade:

Contratação com base no inciso IX dependerá, certamente, de circunstanciada justificativa na qual se exponham os fatos objetivos e as razões que a fazem indeclinável. À falta disto, será nula. A violação destes condicionamentos a que se aludiu e que, parece-nos, são simples decorrências implícitas no rigor do dispositivo, acarretará as consequências previstas no já aludido $§ 2 .^{\circ}$ do artigo 37, isto é: "nulidade do ato e punição da autoridade responsável, nos termos da lei". Sobremais, como é natural, ensejará a qualquer cidadão a propositura de ação popular (art. 5. ${ }^{\circ}$, LXXIII), para fulminação do contrato e

\footnotetext{
${ }^{247}$ JÈZE, Gaston. Principios generales del derecho administrativo. Buenos Aires: Depalma, 1949, v. 3, p. 239 e p. 285.

${ }^{248}$ ARAÚJO, Edmir Netto de. Convalidação do ato administrativo. São Paulo: LTR, 1999 , p. 40.

${ }^{249}$ CINTRA, Antônio Carlos de Araújo. Motivo e motivação do ato administrativo. São Paulo: Revista dos Tribunais, 1979, p. 89.

${ }^{250}$ DI PIETRO, 2013, p. 219.
} 
condenação da autoridade responsável a ressarcir os cofres públicos pela despesa dele resultante ${ }^{251}$.

Assim, a contratação temporária deve ser devidamente motivada, entrando em cena o princípio da motivação, expondo-se as razões de fato e de direito que autorizam a contratação, sob pena de nulidade.

\subsection{CONSIDERAÇÕES SOBRE A LEGISLAÇÃO FEDERAL EM VIGOR E HIPÓTESES DE CONTRATAÇÃO TEMPORÁRIA NO ÂMBITO FEDERAL, A PARTIR DA LEI N. ${ }^{\circ} 8.745 / 93$}

A maioria dos casos em que se utiliza da contratação temporária tem por objetivo solucionar ou minimizar problema repentinamente surgido. São situações que ultrapassam a normalidade, são contratações provisórias em casos excepcionais que precisam ser solucionados imediatamente: no campo da saúde pública, para o incremento do número de médicos, enfermeiros e agentes de saúde, em razão de epidemia que demanda de forma transitória a presença de mais pessoas, ou na educação, permitindo a contratação de professores.

Bem explicam Cristiana Fortini e Flávia Cristina Mendonça Faria da Pieve:

Cogitar do aumento de servidores públicos estatutários e de empregados públicos, quando se sabe temporário o problema, não se justifica, seja por razões de ordem econômico-financeira, seja porque demandaria a edição de leis (no que concerne aos cargos públicos).

Importa observar que, na situação acima narrada não importa se a atividade a ser desempenhada é permanente ou temporária. Basta que a demanda a ser suprida caracterize-se pela sua transitoriedade. É o que ocorre com a contratação temporária destinada a suprir o afastamento de servidora efetiva em licença-maternidade ${ }^{252}$.

Na redação original da Lei n. ${ }^{\circ}$ 8.745/93, era considerada necessidade temporária de excepcional interesse público para contratação por um prazo máximo de quatro anos:

a) assistência a situações de calamidade pública,

b) combate a surtos endêmicos;

c) realização de recenseamentos;

d) admissão de professor substituto e de professor visitante;

e) admissão de professor e de pesquisador visitante estrangeiro;

f) atividades especiais nas organizações das Forças Armadas para atender à área industrial ou a encargos temporários de obras e serviços de engenharia.

${ }^{251}$ MELLO, 1991, p. 83-84, grifo do autor.

${ }^{252}$ FORTINI; PIEVE, 2012, p. 23. 
A Lei n. ${ }^{\circ}$ 9.849/99 aumentou as hipóteses de contratação temporária. Passou a ser considerada necessidade temporária de excepcional interesse público:

I - assistência a situações de calamidade pública;

II - combate a surtos endêmicos;

III - realização de recenseamentos e de outras pesquisas de natureza estatística efetuadas pela Fundação Instituto Brasileiro de Geografia e Estatística - IBGE;

IV - admissão de professor substituto e de professor visitante;

$\mathrm{V}$ - admissão de professor e de pesquisador visitante estrangeiro;

VI - as atividades:

a) especiais nas organizações das Forças Armadas para atender à área industrial ou a encargos temporários de obras e serviços de engenharia;

b) de identificação e demarcação desenvolvidas pela Funai;

c) de análise e registro de marcas e patentes pelo Instituto Nacional da Propriedade Industrial - INPI;

d) finalísticas do Hospital das Forças Armadas;

e) de pesquisa e desenvolvimento de produtos destinados à segurança de sistemas de informações, sob a responsabilidade do Centro de Pesquisa e Desenvolvimento para a Segurança das Comunicações Cepesc;

f) de vigilância e inspeção, relacionadas à defesa agropecuária, no âmbito do Ministério da Agricultura e do Abastecimento, para atendimento de situações emergenciais ligadas ao comércio internacional de produtos de origem animal ou vegetal ou de iminente risco à saúde animal, vegetal ou humana;

g) desenvolvidas no âmbito dos projetos do Sistema de Vigilância da Amazônia - SIVAM e do Sistema de Proteção da Amazônia SIPAM.

Com a Lei n. ${ }^{\circ}$ 10.667, de 14 de maio de 2003, foram incluídas as seguintes situações:

h) técnicas especializadas, no âmbito de projetos de cooperação com prazo determinado, implementados mediante acordos internacionais, desde que haja, em seu desempenho, subordinação do contratado ao órgão ou entidade pública.

$\S 3 .^{\circ}$ As contratações a que se refere a alínea $h$ do inciso VI serão feitas exclusivamente por projeto, vedado o aproveitamento dos contratados em qualquer área da administração pública.

A Lei n. ${ }^{\circ} 10.973$, de 2 de dezembro de 2004, por sua vez, acrescentou a seguinte hipótese em suas disposições finais:

VII - admissão de professor, pesquisador e tecnólogo substitutos para suprir a falta de professor, pesquisador ou tecnólogo ocupante de cargo efetivo, decorrente de licença para exercer atividade empresarial relativa à inovação.

Pela Lei n. ${ }^{\circ} 11.784$, de 22 de setembro de 2008, foram incluídas mais situações:

b) de identificação e demarcação territorial; 
i) técnicas especializadas necessárias à implantação de órgãos ou entidades ou de novas atribuições definidas para organizações existentes ou as decorrentes de aumento transitório no volume de trabalho que não possam ser atendidas mediante a aplicação do art. 74 da Lei n. ${ }^{\circ} 8.112$, de 11 de dezembro de 1990;

j) técnicas especializadas de tecnologia da informação, de comunicação e de revisão de processos de trabalho, não alcançadas pela alínea $i$ e que não se caracterizem como atividades permanentes do órgão ou entidade;

1) didático-pedagógicas em escolas de governo;

m) de assistência à saúde para comunidades indígenas;

VIII - admissão de pesquisador, nacional ou estrangeiro, para projeto de pesquisa com prazo determinado, em instituição destinada à pesquisa;

IX - combate a emergências ambientais, na hipótese de declaração, pelo Ministro de Estado do Meio Ambiente, da existência de emergência ambiental na região específica.

As atividades finalísticas do Hospital das Forças Armadas, incluídas pela Lei n. ${ }^{\circ}$ 9.849, tiveram seu prazo prorrogado pela Lei n. ${ }^{\circ} 11.784$, de 2008.

Já a Lei n. ${ }^{\circ} 12.314$, de 19 de agosto de 2010, deu uma nova redação ao artigo 2. ${ }^{\circ}$, inciso II, da Lei n. ${ }^{o} 8.745 / 93$ e incluiu o $§ 4 .^{\circ}$ nesse artigo $2 .^{\circ}$ :

II - assistência a emergências em saúde pública;

$\S 4 .^{\circ}$ Ato do Poder Executivo disporá, para efeitos desta Lei, sobre a declaração de emergências em saúde pública.

A Lei n. ${ }^{\circ}$ 12.425, de 17 de junho de 2011, trouxe novas possibilidades de contratação temporária:

X - admissão de professor para suprir demandas decorrentes da expansão das instituições federais de ensino, respeitados os limites e as condições fixados em ato conjunto dos Ministérios do Planejamento, Orçamento e Gestão e da Educação.

$\S 1 .^{\circ}$ A contratação de professor substituto de que trata o inciso IV do caput poderá ocorrer para suprir a falta de professor efetivo em razão de:

I - vacância do cargo;

II - afastamento ou licença, na forma do regulamento;

III - nomeação para ocupar cargo de direção de reitor, vice-reitor, próreitor e diretor de campus.

$\S 2 .^{\circ} \mathrm{O}$ número total de professores de que trata o inciso IV do caput não poderá ultrapassar $20 \%$ (vinte por cento) do total de docentes efetivos em exercício na instituição federal de ensino.

A Lei n. ${ }^{\circ}$ 12.772, de 28 de dezembro de 2012, por sua vez, incluiu outras hipóteses no artigo $2 .^{\circ}$ da Lei 8.745 , de 1993 :

$\S 5^{\circ}$ A contratação de professor visitante e de professor visitante estrangeiro, de que tratam os incisos IV e V do caput, tem por objetivo:

I - apoiar a execução dos programas de pós-graduação stricto sensu;

II - contribuir para o aprimoramento de programas de ensino, pesquisa e extensão;

III - contribuir para a execução de programas de capacitação docente; ou IV - viabilizar o intercâmbio científico e tecnológico. 
$\S 6^{\circ}$ A contratação de professor visitante e o professor visitante estrangeiro, de que tratam os incisos IV e V do caput, deverão:

I - atender a requisitos de titulação e competência profissional; ou

II - ter reconhecido renome em sua área profissional, atestado por deliberação do Conselho Superior da instituição contratante.

$\S 7 .^{\circ}$ São requisitos mínimos de titulação e competência profissional para a contratação de professor visitante ou de professor visitante estrangeiro, de que tratam os incisos IV e V do caput:

I - ser portador do título de doutor, no mínimo, há 2 (dois) anos;

II - ser docente ou pesquisador de reconhecida competência em sua área; $\mathrm{e}$

III - ter produção científica relevante, preferencialmente nos últimos 5 (cinco) anos.

$\S 8 .^{\circ}$ Excepcionalmente, no âmbito das Instituições da Rede Federal de Educação Profissional, Científica e Tecnológica, poderão ser contratados professor visitante ou professor visitante estrangeiro, sem o título de doutor, desde que possuam comprovada competência em ensino, pesquisa e extensão tecnológicos ou reconhecimento da qualificação profissional pelo mercado de trabalho, na forma prevista pelo Conselho Superior da instituição contratante.

$\S 90^{\circ}$ A contratação de professores substitutos, professores visitantes e professores visitantes estrangeiros poderá ser autorizada pelo dirigente da instituição, condicionada à existência de recursos orçamentários e financeiros para fazer frente às despesas decorrentes da contratação e ao quantitativo máximo de contratos estabelecido para a IFE.

$\S 10$ A contratação dos professores substitutos fica limitada ao regime de trabalho de 20 (vinte) horas ou 40 (quarenta) horas.

A Lei n. ${ }^{\circ}$ 12.871, de 22 de outubro de 2013, instituiu o Programa Mais Médicos. Para isso, alterou a Lei n. ${ }^{\circ} 8.745$, de 9 de dezembro de 1993:

XI - admissão de professor para suprir demandas excepcionais decorrentes de programas e projetos de aperfeiçoamento de médicos na área de Atenção Básica em saúde em regiões prioritárias para o Sistema Único de Saúde (SUS), mediante integração ensino-serviço, respeitados os limites e as condições fixados em ato conjunto dos Ministros de Estado do Planejamento, Orçamento e Gestão, da Saúde e da Educação.

A Lei n. ${ }^{\circ} 12.998$, de 18 de junho de 2014, alterou a Lei n. ${ }^{\circ} 8.745$, de 9 de dezembro de 1993, no que diz respeito ao prazo do contrato e à remuneração. Atualmente, o texto da Lei.$^{\circ}$ 8.745, de 9 de dezembro de 1993, encontra-se assim redigido:

Art. 2. ${ }^{\circ}$ Considera-se necessidade temporária de excepcional interesse público:

I - assistência a situações de calamidade pública;

II - assistência a emergências em saúde pública; (Redação dada pela Lei n. ${ }^{\circ} 12.314$, de 2010)

III - realização de recenseamentos e outras pesquisas de natureza estatística efetuadas pela Fundação Instituto Brasileiro de Geografia e Estatística - IBGE; (Redação dada pela Lei n. ${ }^{\circ} 9.849$, de 1999).

IV - admissão de professor substituto e professor visitante;

$\mathrm{V}$ - admissão de professor e pesquisador visitante estrangeiro;

VI - atividades: (Redação dada pela Lei n. ${ }^{\circ}$ 9.849, de 1999). 
a) especiais nas organizações das Forças Armadas para atender à área industrial ou a encargos temporários de obras e serviços de engenharia; (Incluído pela Lei n. ${ }^{\circ}$ 9.849, de 1999). (Vide Medida Provisória n. ${ }^{\circ} 341$, de 2006).

b) de identificação e demarcação territorial; (Redação dada pela Lei n. ${ }^{\circ}$ 11.784, de 2008)

c) (Revogado pela Lei n. ${ }^{\circ} 10.667$, de 2003)

d) finalísticas do Hospital das Forças Armadas; (Incluído pela Lei n. ${ }^{\circ}$ 9.849, de 1999). (Prorrogação de prazo pela Lei n. ${ }^{\circ} 11.784$, de 2008)

e) de pesquisa e desenvolvimento de produtos destinados à segurança de sistemas de informações, sob responsabilidade do Centro de Pesquisa e Desenvolvimento para a Segurança das Comunicações - CEPESC; (Incluído pela Lei n. ${ }^{\circ} 9.849$, de 1999).

f) de vigilância e inspeção, relacionadas à defesa agropecuária, no âmbito do Ministério da Agricultura e do Abastecimento, para atendimento de situações emergenciais ligadas ao comércio internacional de produtos de origem animal ou vegetal ou de iminente risco à saúde animal, vegetal ou humana; (Incluído pela Lei n. ${ }^{\circ} 9.849$, de 1999). (Vide Medida Provisória n. ${ }^{\circ} 341$, de 2006).

g) desenvolvidas no âmbito dos projetos do Sistema de Vigilância da Amazônia - SIVAM e do Sistema de Proteção da Amazônia - SIPAM. (Incluído pela Lei n. ${ }^{\circ}$ 9.849, de 1999).

h) técnicas especializadas, no âmbito de projetos de cooperação com prazo determinado, implementados mediante acordos internacionais, desde que haja, em seu desempenho, subordinação do contratado ao órgão ou entidade pública. (Incluído pela Lei n. ${ }^{\circ}$ 10.667, de 2003) (Vide Medida Provisória n. ${ }^{\circ} 341$, de 2006).

i) técnicas especializadas necessárias à implantação de órgãos ou entidades ou de novas atribuições definidas para organizações existentes ou as decorrentes de aumento transitório no volume de trabalho que não possam ser atendidas mediante a aplicação do art. 74 da Lei n.o 8.112, de 11 de dezembro de 1990; (Incluído pela Lei n.o 11.784, de 2008)

j) técnicas especializadas de tecnologia da informação, de comunicação e de revisão de processos de trabalho, não alcançadas pela alínea $i$ e que não se caracterizem como atividades permanentes do órgão ou entidade; (Incluído pela Lei n. ${ }^{\circ} 11.784$, de 2008)

1) didático-pedagógicas em escolas de governo; e (Incluído pela Lei n. ${ }^{\circ}$ 11.784, de 2008)

m) de assistência à saúde para comunidades indígenas; e (Incluído pela Lei n. ${ }^{\circ}$ 11.784, de 2008)

VII - admissão de professor, pesquisador e tecnólogo substitutos para suprir a falta de professor, pesquisador ou tecnólogo ocupante de cargo efetivo, decorrente de licença para exercer atividade empresarial relativa à inovação. (Incluído pela Lei n. ${ }^{\circ} 10.973$, de 2004)

VIII - admissão de pesquisador, nacional ou estrangeiro, para projeto de pesquisa com prazo determinado, em instituição destinada à pesquisa; e (Incluído pela Lei n. ${ }^{\circ} 11.784$, de 2008)

IX - combate a emergências ambientais, na hipótese de declaração, pelo Ministro de Estado do Meio Ambiente, da existência de emergência ambiental na região específica. (Incluído pela Lei n. ${ }^{\circ} 11.784$, de 2008)

$\mathrm{X}$ - admissão de professor para suprir demandas decorrentes da expansão das instituições federais de ensino, respeitados os limites e as condições fixados em ato conjunto dos Ministérios do Planejamento, Orçamento e Gestão e da Educação. (Incluído pela Lei n. ${ }^{\circ}$ 12.425, de 2011) 
XI - admissão de professor para suprir demandas excepcionais decorrentes de programas e projetos de aperfeiçoamento de médicos na área de Atenção Básica em saúde em regiões prioritárias para o Sistema Único de Saúde (SUS), mediante integração ensino-serviço, respeitados os limites e as condições fixados em ato conjunto dos Ministros de Estado do Planejamento, Orçamento e Gestão, da Saúde e da Educação. (Incluído pela Lei n. ${ }^{\circ} 12.871$, de 2013)

$\S 1 .^{\circ}$ A contratação de professor substituto de que trata o inciso IV do caput poderá ocorrer para suprir a falta de professor efetivo em razão de: (Incluído pela Lei n. ${ }^{\circ} 12.425$, de 2011)

I - vacância do cargo; (Incluído pela Lei n. ${ }^{\circ} 12.425$, de 2011)

II - afastamento ou licença, na forma do regulamento; ou (Incluído pela Lei . $^{\circ} 12.425$, de 2011)

III - nomeação para ocupar cargo de direção de reitor, vice-reitor, próreitor e diretor de campus. (Incluído pela Lei n. ${ }^{\circ} 12.425$, de 2011)

$\S 2 .^{\circ} \mathrm{O}$ número total de professores de que trata o inciso IV do caput não poderá ultrapassar $20 \%$ (vinte por cento) do total de docentes efetivos em exercício na instituição federal de ensino. (Incluído pela Lei n. ${ }^{\circ} 12.425$, de 2011)

$\S 3 .^{\circ}$ As contratações a que se refere a alínea $h$ do inciso VI serão feitas exclusivamente por projeto, vedado o aproveitamento dos contratados em qualquer área da administração pública. (Incluído pela Lei n. ${ }^{\circ}$ 10.667, de 14.5.2003)

$\S 4 .^{\circ}$ Ato do Poder Executivo disporá, para efeitos desta Lei, sobre a declaração de emergências em saúde pública. (Incluído pela Lei n. ${ }^{\circ}$ 12.314, de 2010)

$\S 5 .^{\circ}$ A contratação de professor visitante e de professor visitante estrangeiro, de que tratam os incisos IV e $\mathrm{V}$ do caput, tem por objetivo: (Incluído pela Lei n. ${ }^{\circ} 12.772$, de 2012)

I - apoiar a execução dos programas de pós-graduação stricto sensu; (Incluído pela Lei n. ${ }^{\circ} 12.772$, de 2012)

II - contribuir para o aprimoramento de programas de ensino, pesquisa e extensão; (Incluído pela Lei n. ${ }^{\circ} 12.772$, de 2012)

III - contribuir para a execução de programas de capacitação docente; ou (Incluído pela Lei n. ${ }^{\circ} 12.772$, de 2012)

IV - viabilizar o intercâmbio científico e tecnológico. (Incluído pela Lei n. ${ }^{\circ} 12.772$, de 2012)

$\S 6 .^{\circ}$ A contratação de professor visitante e o professor visitante estrangeiro, de que tratam os incisos IV e V do caput, deverão: (Incluído pela Lei n. ${ }^{\circ} 12.772$, de 2012)

I - atender a requisitos de titulação e competência profissional; ou (Incluído pela Lei n. ${ }^{\circ} 12.772$, de 2012)

II - ter reconhecido renome em sua área profissional, atestado por deliberação do Conselho Superior da instituição contratante. (Incluído pela Lei n. ${ }^{\circ}$ 12.772, de 2012)

$\S 7$. $^{\circ}$ São requisitos mínimos de titulação e competência profissional para a contratação de professor visitante ou de professor visitante estrangeiro, de que tratam os incisos IV e V do caput: (Incluído pela Lei n. ${ }^{\circ} 12.772$, de 2012)

I - ser portador do título de doutor, no mínimo, há 2 (dois) anos; (Incluído pela Lei n. ${ }^{\circ}$ 12.772, de 2012)

II - ser docente ou pesquisador de reconhecida competência em sua área; e (Incluído pela Lei n. ${ }^{\circ} 12.772$, de 2012)

III - ter produção científica relevante, preferencialmente nos últimos 5 (cinco) anos. (Incluído pela Lei n. ${ }^{\circ} 12.772$, de 2012) 
$\S 8 .^{\circ}$ Excepcionalmente, no âmbito das Instituições da Rede Federal de Educação Profissional, Científica e Tecnológica, poderão ser contratados professor visitante ou professor visitante estrangeiro, sem o título de doutor, desde que possuam comprovada competência em ensino, pesquisa e extensão tecnológicos ou reconhecimento da qualificação profissional pelo mercado de trabalho, na forma prevista pelo Conselho Superior da instituição contratante. (Incluído pela Lei n. ${ }^{\circ} 12.772$, de 2012)

$\S 90^{\circ}$ A contratação de professores substitutos, professores visitantes e professores visitantes estrangeiros poderá ser autorizada pelo dirigente da instituição, condicionada à existência de recursos orçamentários e financeiros para fazer frente às despesas decorrentes da contratação e ao quantitativo máximo de contratos estabelecido para a IFE. (Incluído pela Lei n. ${ }^{\circ} 12.772$, de 2012)

$\S 10$ A contratação dos professores substitutos fica limitada ao regime de trabalho de 20 (vinte) horas ou 40 (quarenta) horas. (Incluído pela Lei n. ${ }^{\circ}$ 12.772, de 2012)

Entende-se que, na Lei n. ${ }^{\circ}$ 8.745, de 9 de dezembro de 1993, criada para regulamentar o inciso IX do artigo 37 da Constituição da República, foram realmente previstos casos de necessidade temporária de excepcional interesse público. As situações criadas pela lei visam preservar as seguintes áreas: saúde, educação, segurança, ambiental e calamidade pública. Paira dúvida sobre a constitucionalidade das demais situações criadas posteriormente pelo legislador ordinário, pelas leis e medidas provisórias posteriores.

\subsection{FRAUDE NA INTERPRETAÇÃO E NA APLICAÇÃO DO COMANDO CONSTITUCIONAL: CONTRATAÇÕ̃ES TEMPORÁRIAS INVÁLIDAS}

Como já ficou registrado neste trabalho, a admissão temporária no serviço público sem o devido concurso público só é possível em situação restrita de excepcional interesse público. Não há na lei que estabelece os casos de contratação temporária nenhuma discricionariedade $^{253}$ conferida pela Constituição. Deve ser observado única e exclusivamente o atendimento de necessidade temporária de excepcional interesse público.

Márcio Barbosa Maia e Ronaldo Pinheiro de Queiroz abordam a questão das contratações temporárias fraudulentas e apontam o legislador ordinário ou o Executivo, por via de medidas provisórias, como os principais culpados pelas fraudes na contratação temporária:

Portanto, a lei ordinária, que é o veículo normativo para estabelecer os casos de exceção, não pode fugir da razoabilidade e criar situações que

${ }^{253}$ Maria Sylvia Zanella Di Pietro define discricionariedade administrativa como "a faculdade que a lei confere à Administração para apreciar o caso concreto, segundo critérios de oportunidade e conveniência, e escolher uma dentre duas ou mais soluções, todas válidas perante o direito" (DI PIETRO, 2001. p. 67). 
não a de extremo interesse público, fugindo da vontade expressa do legislador constituinte, que se confunde com a própria mens legis.

Nesse sentido, percebe-se que o principal responsável pelas hipóteses de burla ao concurso público por meio de contratação temporária é o próprio legislador ordinário - ou o Executivo, fazendo uso de sua função atípica de legislar via medida provisória, momento em que, não atendendo ao comando constitucional, edita lei estabelecendo caso de contratação temporária, que foge das reais situações de necessidade temporária de excepcional interesse público ${ }^{254}$.

José dos Santos Carvalho Filho chama a atenção para a terceirização no setor público e afirma:

$\mathrm{O}$ verdadeiro servidor temporário, regido pelo regime especial, qualificase como servidor público, configurando-se entre ele e o Poder Público um vínculo de subordinação no que diz respeito à força de trabalho oferecida pelo servidor, muito embora seja temporária a função para a qual foi recrutado. Resulta, pois, que o recrutamento nas condições estabelecidas na Constituição não traduz nenhuma terceirização, mas sim uma convocação de servidores públicos para o exercício de função pública.

Contrariamente, para serviços técnicos profissionais especializados, que se caracterizem como atividades-meio, a outorga da atividade concretiza um processo de terceirização. São hipóteses inteiramente diversas ${ }^{255}$.

O referido autor lamenta, pois, apesar das distinções, tem sido habitual o recrutamento de servidores temporários para o exercício permanente de funções comuns, em evidente descompasso com o modelo permitido na Constituição, o que constitui um verdadeiro desvio de finalidade relativamente ao escopo da norma constitucional:

Referidos fundamentos induzem à conclusão de que o recrutamento de servidores temporários para o exercício de funções permanentes do órgão público constitui, indiscutivelmente, terceirização ilícita, embora sob o manto dissimulado de mero recrutamento funcional de servidor.

Não obstante, quando esse recrutamento desobedece aos parâmetros constitucionais, configurado estará um processo de terceirização ilícita, o que equivale a dizer que foram outorgadas a terceiros (admitidos ilicitamente) atribuições próprias de servidores públicos ${ }^{256}$.

Márcio Barbosa Maia e Ronaldo Pinheiro de Queiroz tecem severas críticas à posição adotada pelo Supremo Tribunal Federal no julgamento da Ação Direta de Inconstitucionalidade n. ${ }^{\circ}$ 3.068-0 (CADE), em 25 de agosto de 2004, na qual se reconhece a possibilidade de contratação temporária para o exercício de atividades permanentes da administração pública:

\footnotetext{
${ }^{254}$ MAIA; QUEIROZ, 2007, p. 60.

${ }^{255}$ CARVALHO FILHO, José dos Santos. Terceirização no setor público: encontros e desencontros. In: FORTINI, Cristiana (Org.). Terceirização na Administração: estudos em homenagem ao professor Pedro Paulo de Almeida Dutra. 2. ed. Belo Horizonte: Fórum, 2012b, p. 66-67.

${ }^{256}$ CARVALHO FILHO, 2012b, p. 66-67.
} 
Percebeu-se que o Supremo seguiu a linha da corrente doutrinária que também admite contratações temporárias para suprir necessidades de serviços de natureza permanente. Até aí tudo bem. Acontece que o alcance que a nossa Corte Constitucional deu à expressão necessidade temporária de excepcional interesse público foi muito amplo, servindo, basicamente de válvula de escape para todo tipo de contratação, sempre quando demonstrada a carência de pessoal. Ora, sucateado como hoje está o serviço público, e como a carência de pessoal não deixa de ser uma apreciação subjetiva, não há dúvida de que quase todos os setores da administração pública estão agora legitimados a contratar temporariamente um contingente de pessoas para o fim de suprir tais deficiências. $\mathrm{O}$ grande problema é que as pessoas que irão desempenhar essas funções permanentes, recebendo treinamento adequado para tanto muitas vezes com investimento financeiro pelo Estado bastante considerável -, tendo acesso a informações sensíveis, relacionando-se com pessoas com poder de decisões importantes, entre outros fatores, quando estiverem "engrenando" no trabalho, terão de deixar o serviço público $^{257}$.

O grande perigo é que o concurso público para ingresso no serviço público deixe de ser a regra e ocorra a "fuga para o direito privado", tão bem exposta por Maria João Estorninho $^{258}$. O importante é ressaltar que só pode haver contratação temporária em casos de necessidade temporária para atender excepcional interesse público. Essa situação é a exceção, e não a regra. A regra é o concurso público.

\subsection{A CONTRIBUIÇÃO DA JURISPRUDÊNCIA PARA O ENTENDIMENTO DA NORMA CONSTITUCIONAL}

Há uma controvérsia acerca da possibilidade de contratação por tempo determinado de servidores para o exercício de funções permanentes.

Durante muito tempo, o Supremo Tribunal Federal entendeu que a contratação por tempo determinado não poderia ser feita para o exercício de funções permanentes, conforme Ações Diretas de Inconstitucionalidade n. ${ }^{\circ}$ 2.125-7, de 1999 (INPI), n. ${ }^{\circ}$ 2.380-2, de 2000 (INPI), n. ${ }^{\circ}$ 2.229-6, de 2000 (contratação temporária de defensores públicos).

A partir do julgamento da Ação Direta de Inconstitucionalidade n. ${ }^{\circ}$ 3.068-0 (CADE), em 25 de agosto de 2004, o Supremo Tribunal Federal reconheceu a possibilidade de contratação temporária para o exercício de atividades permanentes da administração pública ${ }^{259}$. Em um julgamento apertado, o relator Ministro Eros Grau afirmou:

\footnotetext{
${ }^{257}$ MAIA; QUEIROZ, 2007, p. 64.

${ }^{258}$ ESTORNINHO, 2009, p. 17.

${ }^{259}$ Tal posicionamento do Supremo Tribunal Federal é criticado por Márcio Barbosa Maia e Ronaldo
} 
O inciso IX do artigo 37 da Constituição do Brasil não separa, de um lado, atividades a serem desempenhadas em caráter eventual, temporário ou excepcional e, de outro, atividades de caráter regular e permanente. Não autoriza exclusivamente a contratação por tempo determinado de pessoal que desempenhe atividades em caráter eventual, temporário ou excepcional. Amplamente, autoriza contratações para atender a necessidade temporária de excepcional interesse público em uma e outra hipótese. Seja para o desempenho das primeiras, seja para o desempenho de atividades de caráter regular e permanente, desde que a contratação seja indispensável ao atendimento de necessidade temporária de excepcional interesse público.

Ocorre que, no julgamento da Ação Direta de Inconstitucionalidade n. ${ }^{\circ} 3.700$, em 15 de outubro de 2008, o Supremo Tribunal Federal adotou a posição vencedora no julgamento da Ação Direta de Inconstitucionalidade n. ${ }^{\circ}$ 2.229-6, sobre a contratação temporária de advogados para o exercício de função de defensor público, no âmbito da Defensoria Pública do Estado do Rio Grande do Norte. Considerou-se que, em razão de desempenhar uma atividade estatal permanente e essencial à jurisdição, a Defensoria Pública não convive com a possibilidade de que seus agentes sejam recrutados em caráter precário.

Em razão de abusos cometidos no passado, para os denominados "extranumerários" e "interinos", é que se pode entender a posição restritiva do Supremo Tribunal Federal. Todavia, não se pode condenar o instituto da contratação temporária.

Realmente, como argumenta o Ministro Eros Grau, não há na Constituição Federal distinção entre atividades permanentes e atividades temporárias quando se trata da contratação temporária do artigo 37, IX.

Enfatiza Florivaldo Dutra de Araújo, ao tratar do dispositivo 37, IX, da Constituição Federal:

Com efeito, esse dispositivo prevê "contratação por tempo determinado para atender a necessidade temporária" e não "contratação para atividades temporárias". Uma atividade pode ser permanente, mas a quantidade de pessoal necessário para exercê-la poderá ser excepcionalmente maior por determinado período de tempo, o que justifica a contratação temporária, e

\footnotetext{
Pinheiro de Queiroz pelo fato de que o CADE já existe há dez longos anos! Por mais incrível que possa parecer, foi mais fácil para o Governo, nesse longo período, aprovar diplomas legislativos autorizadores de contratações temporárias do que promover os competentes concursos públicos a fim de regularizar a situação de seu pessoal. Mesmo indagado sobre tal dado da realidade, o ilustre Ministro Eros Grau, condutor da votação majoritária, afirmou que "esse Tribunal não pode punir a inércia da administração. É um Tribunal que deve considerar fundamentalmente o que está escrito na Constituição". Salvo engano, acima do inciso IX do artigo 37 dessa mesma Constituição, aparece o inciso II, que estabelece a obrigatoriedade de concurso público. Um pouco mais acima, mais precisamente no caput do artigo 37, o enunciado proclama que a Administração reger-se-á pelo princípio da moralidade. Mais apropriadas, isso sim, são as palavras do eminente Ministro Sepúlveda Pertence: "estamos abrindo uma porta à fraude sistemática do concurso público" (MAIA; QUEIROZ, 2007, p. 63-64).
} 
não a admissão em caráter permanente. Suponha-se a ocorrência de uma epidemia, a exigir, por certo tempo, maior número de servidores da área da saúde. As atividades desse setor são permanentes para a administração pública, mas uma necessidade temporária obriga à contratação por tempo determinado $^{260}$.

Florivaldo Dutra de Araújo adverte:

$\mathrm{O}$ posicionamento rígido, de se condenar qualquer hipótese de contratação temporária para o exercício de atividades permanentes, poderá ter o perverso efeito de induzir a administração pública a admitir, em cargos de provimento efetivo, maior número de servidores do que o normalmente necessário, apenas para se precaver contra eventuais situações de necessidade temporária. Tal situação ofenderia, no mínimo, os princípios da eficiência e da economicidade, previstos na $\mathrm{CF}$, artigos 37 e 70. A administração pública somente deve admitir, em caráter permanente, o quantitativo de servidores normalmente necessário ao cumprimento de suas atribuições. Caso se apresente qualquer situação transitória, que leve ao acréscimo excepcional dessas atribuições, estaremos diante de necessidade temporária prevista no art. 37, IX, $\mathrm{CF}^{261}$.

Cármen Lúcia Antunes Rocha entende que, mesmo para o desempenho de funções inerentes a cargos públicos, pode ser configurada situação prevista na norma constitucional do artigo 37, IX, mas assinala:

Duas observações, contudo, devem ser relevadas: a primeira, no sentido de que quando sobrevier hipótese como aquela acima figurada, qual seja, a de contratação para suprir necessidade temporária de funções permanentes e enfeixadas em cargo, somente se pode dar a contratação enquanto não se chegar à realização do concurso que se torna obrigatório. A contratação impõe, obriga, determina o início e a continuidade de providências para o aperfeiçoamento do certame, o qual, conduzirá à extinção da condição criada mediante o contrato transitório; a segunda respeita à natureza do cargo que, desprovido, pode determinar a contratação temporária em face da urgência e imprescindibilidade do exercício de suas funções. Somente para cargo público cujo provimento seja de natureza efetiva pode vir a ser objeto da contratação aqui prevista, pois poder-se-ia cogitar da hipótese de vacância e necessidade de um tempo para a realização do certame correspondente ${ }^{262}$.

Registre-se, inclusive, que o Supremo Tribunal Federal, por ocasião do julgamento da ADIN n. ${ }^{\circ}$ 2.380-2, declarou inconstitucional a alínea "c" do inciso VI do artigo 2..$^{\circ}$ da Lei n. ${ }^{\circ} 9.849 / 99$ e sua menção no $\S 2 .^{\circ}$ do artigo $3 .^{\circ}$ e no inciso III do artigo $4 .^{\circ}$ também da Lei n. ${ }^{\circ}$ 9.849/99, que alterou a redação da Lei n. ${ }^{\circ}$ 8.745/93, uma vez que as atividades relativas à implementação, ao acompanhamento e à avaliação de atividades, projetos e programas de área de competência do INPI ostentam natureza permanente, não se

\footnotetext{
${ }^{260}$ ARAÚJO, 2009, p. 122-123, grifo do autor.

${ }^{261}$ ARAÚJO, 2009, p. 123.

${ }^{262}$ ROCHA, 1999, p. 242-243.
} 
enquadrando nas hipóteses previstas no inciso IX do artigo 37 da Constituição da República $^{263}$.

Quanto ao regime jurídico aplicado, o Superior Tribunal de Justiça (STJ) e os Tribunais Regionais Federais assim se pronunciaram:

\begin{abstract}
Ementa:
ADMINISTRATIVO. PROCESSUAL CIVIL. CONFLITO NEGATIVO DE COMPETÊNCIA. SERVIDOR PÚBLICO MUNICIPAL. CONTRATAÇÃO TEMPORÁRIA. CONTINUIDADE DA PRESTAÇÃO DE SERVIÇOS. VÍNCULO JURÍDICOADMINISTRATIVO INAFASTÁVEL. CONFLITO CONHECIDO. COMPETÊNCIA DA JUSTIÇA COMUM. 1. A Suprema Corte adotou o entendimento de que a mera prorrogação do prazo de contratação de servidor temporário não tem o condão de transmudar o vínculo administrativo que este mantinha com o Estado em relação de natureza trabalhista (RE 573.202/AM, Rel. Min. Ricardo Lewandowski). 2. Conflito de competência conhecido para declarar competente o Juízo de Direito do Distrito de Monte Alegre - Poço Redondo/SE, o suscitado ${ }^{264}$.
\end{abstract}

Ementa:

FGTS. RECOLHIMENTO DE CONTRIBUIÇÕES POR AGÊNCIA REGULADORA EM RELAÇÃO A CONTRATO TEMPORÁRIO FIRMADO PELAS DISPOSIÇÕES DA LEI N. ${ }^{\circ}$ 8.745/93. RELAÇÃO SUJEITA AO REGIME JURÍDICO-ADMINISTRATIVO. INEXIGIBILIDADE. 1 . A Lei . $^{\circ}$ 8.745/93 disciplinou a norma constante do art. 37, IX, da Constituição Federal, dispondo sobre a contratação por tempo determinado para atender a necessidade temporária de excepcional interesse público. 2. O contrato firmado pelas disposições da Lei n. ${ }^{\circ}$ $8.745 / 93$ vincula-se ao regime jurídico administrativo, de forma que o contratado não pode ser, sequer, equiparado ao trabalhador conceituado na CLT, mais se assemelhando ao servidor estatutário, especialmente porque o art. 11 da referida Lei determina a aplicação de disposições da Lei n. $^{\circ} 8.112 / 90$ ao pessoal contratado por tempo determinado. $3 . \mathrm{O} \S 2 .^{\circ}$ do art. 15 da Lei $n .^{\circ} 8.036 / 90$ exclui a obrigatoriedade de recolhimento de FGTS quanto aos eventuais, os autônomos e os servidores públicos civis e militares sujeitos a regime jurídico próprio. Os contratados em regime excepcional temporário da Lei $n .^{\circ}$ 8.745/93, por seu regime especial, estão excluídos do FGTS, assim como os servidores públicos civis regidos pela Lei n. $^{\circ}$ 8.112/90. Precedentes. 4. Não prospera a pretensão da parte apelante em obter condenação da ANEEL ao recolhimento de contribuições ao FGTS em decorrência de contrato temporário firmado pelas disposições da Lei n. $^{\circ}$ 8.745/93. 5. Apelação da parte autora improvida $^{265}$.

\footnotetext{
${ }^{263}$ MAIA, Márcio Barbosa e QUEIROZ, Ronaldo Pinheiro de. O regime jurídico do concurso público e o seu controle jurisdicional. São Paulo: Saraiva, 2007. p. 63.

${ }^{264}$ STJ. CC 200901364585. CC - CONFLITO DE COMPETÊNCIA - 106643. TERCEIRA SEÇÃO. Relator: JORGE MUSSI. Data da decisão: 28/04/2010. Data da publicação: 02/08/2010.

${ }^{265}$ TRF1. AC 200834000132451. AC - APELAÇÃO CIVEL - 200834000132451. QUINTA TURMA. Relator: JUIZ FEDERAL PAULO ERNANE MOREIRA BARROS (CONV.). Data da decisão: 20/02/2013. Data da publicação: 07/03/2013.
} 
Ementa:

FGTS. CONTRATAÇÃO TEMPORÁRIA. LEI 8.745/95. IMPOSSIBILIDADE. CONTRATO REGIDO PELO DIREITO PÚBLICO. VALIDADE DO CONCURSO PÚBLICO. INAPLICABILIDADE DA SÚMULA 363 DO TST. 1. A Lei n. ${ }^{\circ}$ 8.745/93 disciplinou a norma constante do art. 37, IX, da Constituição Federal, sobre a contratação por tempo determinado para atender a necessidade temporária de excepcional interesse público. 2. O contrato firmado pelas disposições da Lei $n^{\circ}{ }^{8} 8.745 / 93$ vincula-se ao regime estatutário dado pela Lei $\mathrm{n}^{\circ}{ }^{\circ} 8.112 / 90$, de forma que o contratado não se equipara ao trabalhador conceituado na CLT, mas sim servidor estatutário, especialmente porque o art. 11 da referida lei determina a aplicação de disposições da Lei n. ${ }^{\circ} 8.112 / 90$ ao pessoal contratado por tempo determinado. 3. Constata-se que o seu $\S 2 .^{\circ}$ do art. 15 da Lei . $^{\circ}$ $8.036 / 90$ exclui a obrigatoriedade de recolhimento quanto aos eventuais, os autônomos e os servidores públicos civis e militares sujeitos a regime jurídico próprio. 4. Resta clara a validade do concurso público, não se aplicando a Súmula 363 do TST ao caso, pois, conforme processo administrativo, a apelante foi contratada mediante concurso público de rito simplificado nos termos da Lei n. $^{\circ} 8.112 / 90 \mathrm{com}$ as alterações da Lei n. ${ }^{\circ} 8.745 / 93$, Lei n. ${ }^{\circ} 9.849 / 99$ e Lei $.^{\circ}{ }^{10} 10.667 / 03$ para exercer a função de professora substituta de forma temporária para atendimento de excepcional interesse público. 5. Apelação a que se nega provimento ${ }^{266}$.

Os requisitos constitucionais constantes do artigo 37, IX, da Constituição Federal devem estar presentes, sob pena de serem declaradas inconstitucionais as leis que preveem a contratação de servidores temporários, como aconteceu com leis municipais que previam contratações sem concurso público.

O Supremo Tribunal Federal declarou a inconstitucionalidade de leis nos municípios mineiros de Bertópolis, Estrela do Sul e Congonhal. As normas previam a contratação temporária de servidores públicos de forma genérica.

Os requisitos constitucionais devem estar presentes nas hipóteses de contratação temporária. Caso não sejam respeitados, configura-se um "salvo conduto para contratações que violem de pronto o princípio republicano do concurso público".

Para o plenário do Supremo Trbunal Federal, ficou evidente, no caso das três leis impugnadas, a previsão genérica de contratação temporária, o que desrespeita a norma geral do concurso público.

Os casos de contratação temporária devem estar expressamente definidos em lei, a contratação deve ser temporária e deve haver excepcional interesse público. As regras estão expressamente definidas no artigo 37 da Constituição Federal, em seus incisos II e IX.

${ }^{266}$ TRF3. AC 00008852620134036115. AC - APELAÇÃO CÍVEL - 1902802. PRIMEIRA TURMA. Relator: DESEMBARGADOR FEDERAL JOSÉ LUNARDELLI. Data da decisão: 10/12/2013. Data da publicação: 15/01/2014. 
O Procurador-Geral da República, Rodrigo Janot, analisando o caso de Bertópolis, ressaltou a generalidade da lei municipal. A lei não prevê as hipóteses em que possa ocorrer a contratação temporária, prevê de forma genérica e abrangente os casos de contratação e tampouco fixa prazo para as contratações excepcionais.

O recurso extraordinário (RE 658026) impugnou dispositivo da Lei n. ${ }^{o}$ 509/1999 do município de Bertópolis. A norma permitia a contratação temporária de servidores públicos para cargos no magistério. Os ministros aplicaram modulação de efeitos para manter a eficácia de contratos celebrados até a data do julgamento (9 de abril de 2014) e assentaram que tais vínculos não podem exceder o prazo de 12 meses.

Também foram declarados inconstitucionais dispositivos da Lei Municipal $\mathrm{n}^{\text {o }}$ 731/2003, de Estrela do Sul, e da Lei Complementar n. ${ }^{\circ}$ 1120/2003, de Congonhal, que trata do estatuto dos servidores municipais. Esses dois últimos casos - RE 556311 e RE 527109, respectivamente - receberam o mesmo tratamento pelo plenário, o provimento do recurso extraordinário com declaração de inconstitucionalidade das normas e modulação de efeitos.

O Supremo Tribunal Federal, em diversas ações ${ }^{267}$, deixa claro que é imprescindível para a contratação temporária a comprovação da necessidade temporária de excepcional interesse público.

${ }^{267}$ Nesse sentido, os seguintes precedentes: ADIN2.380-2/DF; ADIN 1.500-1/ES; RE 168.566-RS; ADIN 2.125 MC/DF; ADIN 2.987/SC. 


\section{RESPONSABILIDADE DO SERVIDOR PÚBLICO TEMPORÁRIO}

\subsection{CONSIDERAÇÕES INICIAIS SOBRE RESPONSABILIDADE}

Inicialmente, esclarece-se que a responsabilidade aqui estudada é a referente ao agente público, ligada à esfera civil, penal, administrativa e agora à improbidade administrativa. Ao longo do trabalho, procurar-se-á identificar e caracterizar as esferas de responsabilidade do agente público, em especial do servidor temporário, os aspectos relacionados à comunicação entre elas, dando-se ênfase à responsabilidade administrativa.

A palavra "responsabilidade" tem origem no latim re-spondere que se liga à noção de segurança ou garantia da restituição ou compensação do bem sacrificado. A noção de responsabilidade traduz a ideia de resposta, com o sentido de responder, replicar.

Rui Stoco esclarece: “[...] a responsabilização é meio e modo de exteriorização da própria Justiça e a responsabilidade é a tradução para o sistema jurídico do dever moral de não prejudicar o outro, ou seja, o neminem laedere ${ }^{\text {,268. }}$.

A palavra responsabilidade, na lição de Edmir Netto de Araújo, sempre conota a ideia da imputabilidade, relativamente ao desequilíbrio causado na ordem natural ou regular das coisas, com a obrigatoriedade do ressarcimento ou reparação desse equilíbrio pelo culpado direto ou indireto do dano material ou moral causado, ou seja, pelo responsável pela ação ou omissão danosa ${ }^{269}$.

Quando se fala em responsabilidade, logo se imagina que alguém (o responsável) deve responder perante a ordem jurídica em virtude de algum fato precedente.

José dos Santos Carvalho Filho identifica dois pontos que constituem pressupostos inafastáveis do instituto da responsabilidade - o fato e a sua imputabilidade a alguém:

De um lado, a ocorrência do fato é indispensável, seja ele de caráter comissivo ou omissivo, por ser ele o verdadeiro gerador dessa situação jurídica. Não pode haver responsabilidade sem que haja um elemento impulsionador prévio. De outro, é necessário que o indivíduo a que se impute responsabilidade tenha a aptidão jurídica de efetivamente responder perante a ordem jurídica pela ocorrência do fato. No que diz respeito ao fato gerador de responsabilidade, não está ele atrelado ao aspecto da licitude ou ilicitude. Como regra, é verdade, o fato ilícito é que acarreta a responsabilidade, mas em ocasiões especiais, o ordenamento jurídico faz nascer a responsabilidade até mesmo de fatos lícitos. Nesse

${ }^{268}$ STOCO, Rui. Responsabilidade civil e sua interpretação jurisprudencial. 4. ed. São Paulo: Revista dos Tribunais, 1999, p. 59.

${ }^{269}$ ARAÚJO, 1994, p. 54. 
ponto, a caracterização do fato como gerador da responsabilidade obedece ao que a lei estabelecer a respeito ${ }^{270}$.

Edmir Netto de Araújo aponta como primeiro elemento da responsabilidade civil a constatação de um ato (ou omissão) humano imputável ao Estado. Adverte o referido autor que não é necessário que seja um ato jurídico, pois pode o dano ao administrado ser decorrente de atos ou omissões materiais do agente causador do prejuízo (no caso, apenas fato jurídico). Como segundo elemento, o autor aponta o nexo de causalidade ${ }^{271}$.

Um primeiro ponto: gera responsabilidade a ocorrência de um fato ou de um ato (ou de uma omissão).

\subsection{FATO JURÍDICO (LATO SENSU)}

Todo direito provém de um fato. Nem todo fato tem força jurídica. Há fatos que são acontecimentos naturais, sem reflexos no mundo jurídico (por exemplo, a chuva que cai) ${ }^{272}$. Quando o fato repercute na esfera jurídica, surge o fato jurídico.

São válidos os ensinamentos de José Cretella Júnior:

Nem todo fato do mundo interessa ao direito. Na verdade, a maioria dos fatos do mundo são estranhos ao mundo jurídico. Só interessa ao mundo jurídico o fato do mundo com implicações jurídicas, acontecimento que interfere na relação de direito, dando-lhe nascimento, extinguindo-a, alterando-a, modificando-a, protegendo-a ${ }^{273}$.

Washington de Barros Monteiro e Ana Cristina de Barros Monteiro França Pinto afirmam que "esses acontecimentos, de que decorrem o nascimento, a subsistência e a perda dos direitos, contemplados em lei, denominam-se fatos jurídicos (lato sensu)"274.

Com exatidão, Edmir Netto de Araújo preleciona:

${ }^{270}$ CARVALHO FILHO, 2012a, p. 541-542.

${ }^{271}$ ARAÚJO, 2014, p. 845-847.

${ }^{272}$ Edmir Netto de Araújo traz à colação as seguintes situações: "Mesmo fatos da natureza, que ocorrem sem qualquer participação humana, voluntária ou involuntária, podem produzir efeitos jurídicos. Um incêndio de causas desconhecidas é, geralmente, fato material não jurídico, mas, se alguém celebrou contrato de seguro contra incêndio para sua casa, esse evento terá consequências para o Direito. Uma enchente na cidade poderá ter por causa a negligência do Poder Público na época das chuvas, pela previsibilidade, decorrente da ocorrência de evento anterior semelhante, e pela não adoção de providências (tais como limpeza do sistema de coleta de esgotos e águas pluviais, desvio do curso de canais, abertura ou fechamento de comportas de represas), desencadeando efeitos jurídicos: responsabilidade patrimonial do Estado perante os administrados prejudicados, ao contrário de inundação imprevisível, irresistível, não periódica" (ARAÚJO, Edmir Netto de. Do negócio jurídico administrativo. São Paulo: Revista dos Tribunais, 1992, p. 16-17, grifo do autor).

${ }^{273}$ CRETELLA JÚNIOR, José. Tratado de direito administrativo. 2. ed. Rio de Janeiro: Forense, 2002, v. 2, p. 10, grifos do autor.

${ }^{274}$ MONTEIRO, Washington de Barros; PINTO, Ana Cristina de Barros Monteiro França. Curso de direito civil. 44 ed. São Paulo: Saraiva, 2012, v. 1, p. 216, grifo dos autores. 
Todavia, os fatos que mais comumente produzem efeitos jurídicos são aqueles que decorrem da ação humana voluntária, sobre a qual a ordem jurídica ora prescreve efeitos jurídicos imediatamente, independentemente do fato de o ser humano desejar ou não tais consequências, ora admite as consequências jurídicas que a vontade do ser humano, com aquela ação, deseja produziri ${ }^{275}$.

O Código Civil de 1916, ao tratar dos fatos jurídicos no Livro III, disciplinava, nas "Disposições preliminares", a aquisição, a conservação, a modificação e a extinção de direitos. Em seguida, no Título I, definia ato jurídico: “Todo ato lícito, que tenha por fim imediato adquirir, resguardar, transferir, modificar ou extinguir direitos, se denomina ato jurídico".

O Código Civil de 2002 substituiu a denominação genérica "ato jurídico" pela designação específica "negócio jurídico", considerando a riqueza de conteúdo, aplicando os preceitos do Livro III.

Encontra-se mantido no Código Civil de 2002, no Livro III da parte geral, o título “DOS FATOS JURÍDICOS”, os quais englobam, em sentido amplo, os negócios jurídicos, os atos jurídicos lícitos e os atos ilícitos.

Observa-se que não há uma definição de fato jurídico nem no Código Civil de 1916, nem no Código Civil de 2002.

Carlos Roberto Gonçalves resume o que seja fato jurídico em sentido amplo como "todo acontecimento da vida que o ordenamento jurídico considera relevante no campo do direito" 276 .

E na classificação apresentada por José Abreu os fatos jurídicos dividem-se em involuntários ou voluntários, que são as ações humanas ${ }^{277}$.

Os fatos jurídicos (lato sensu) podem ser: a) de ordem natural, fato jurídico natural ou fato jurídico stricto sensu; b) ações humanas, fato jurídico voluntário ou ato jurídico lato sensu. Assim, os primeiros têm origem na simples manifestação da natureza e os últimos derivam da atividade humana.

\footnotetext{
275 ARAÚJO, 1992, p. 17.

${ }^{276}$ GONÇALVES, Carlos Roberto. Direito civil brasileiro. 9. ed. São Paulo: Saraiva, 2011, v. 1, p. 316.

277 As ações humanas podem produzir efeitos jurídicos voluntários (no caso dos atos jurídicos em sentido lato, ou negócios jurídicos), ou efeitos jurídicos involuntários (atos jurídicos em sentido estrito, lícitos), ou, até mesmo, efeitos em regra indesejados pelo sujeito (atos ilícitos) (ABREU, José. O negócio jurídico e sua teoria geral. São Paulo: Saraiva, 1988, p. 8-9).
} 


\subsubsection{Fato jurídico stricto sensu ou fato natural}

Fato jurídico stricto sensu seria aquele acontecimento que não depende da vontade humana, mas produz efeitos jurídicos, criando, modificando ou extinguindo direitos.

Maria Helena Diniz classifica o fato jurídico stricto sensu em: ordinários (como morte, nascimento, maioridade, menoridade, aluvião, avulsão) e extraordinários ou irresistíveis (como o caso fortuito e a força maior: terremoto, raio, tempestade) ${ }^{278}$.

São fatos naturais que produzem efeitos jurídicos, mas que não exprimem qualquer atividade humana.

\subsubsection{Ato jurídico lato sensu ou fato humano}

O ato jurídico não é exclusivo do direito privado, nem do direito público, ultrapassa as fronteiras, cabendo o conceito à teoria geral do direito.

Comparando-se ato jurídico e ato administrativo, verifica-se que ato jurídico é gênero e ato administrativo é espécie desse mesmo gênero. Trata-se de uma relação de gênero e espécie, mas ambos possuem idênticos elementos estruturais ${ }^{279}$.

José dos Santos Carvalho Filho, ao comparar as noções de ato jurídico e de ato administrativo, identifica vários pontos comuns:

No direito privado, o ato jurídico possui a característica primordial de ser um ato de vontade, com idoneidade de infundir determinados efeitos no mundo jurídico. [...] Os elementos estruturais do ato jurídico - o sujeito, o objeto, a forma e a própria vontade - garantem sua presença também no ato administrativo. Ocorre que neste o sujeito e o objeto têm qualificações especiais: o sujeito é sempre um agente investido de prerrogativas públicas, e o objeto há de estar preordenado a determinado fim de interesse público. Mas no fundo será ele um instrumento da vontade para a produção dos mesmos efeitos do ato jurídico ${ }^{280}$.

\footnotetext{
${ }^{278}$ DINIZ, Maria Helena. Curso de direito civil brasileiro. 29. ed. São Paulo: Saraiva, 2012, v. 1, p. 429.

279 José Cretella Júnior, ao partir da premissa de que o ato administrativo constitui uma espécie de ato jurídico - que é editado, normalmente, por autoridade administrativa, embora, por exceção, possa nascer da iniciativa de autoridade pública de outros poderes e, mais excepcionalmente, em casos anormais, de pessoa privada que depende de manifestação do Estado; que tem por objeto matéria administrativa -, apresenta a seguinte definição, latissimo sensu: "ato administrativo é a manifestação do Estado, por seus representantes, no exercício regular de suas funções, ou por qualquer pessoa que detenha, nas mãos, fração de poder reconhecido pelo Estado, que tem por finalidade imediata criar, reconhecer, modificar, resguardar ou extinguir determinadas situações jurídicas subjetivas, em matéria administrativa" (CRETELLA JÚNIOR, 2002, v. 2, p. 43-44).

${ }^{280}$ José dos Santos Carvalho Filho observa que na sistemática do novo Código devem os atos administrativos (assim como os atos jurisdicionais e legislativos) enquadrar-se como atos jurídicos porquanto a vontade jurígena será emitida pelos agentes da Administração em conformidade com a lei, mas não poderão ser qualificados como negócios jurídicos, porque a emissão volitiva decorre diretamente da lei, independentemente de o agente desejar, ou não, a finalidade a ser alcançada pelo ato. Nada obstante, é
} 
Assim, ato jurídico lato sensu é um ato humano, ato de vontade que produz efeitos jurídicos.

Quanto à responsabilidade do agente público, defende-se que o ato jurídico pode ser tanto lícito quanto ilícito, apesar de ser mais fácil identificar a responsabilidade na prática de um ato jurídico ilícito.

\subsection{ATO JURÍDICO LÍCITO}

Lícitos são atos humanos a que a lei defere os efeitos desejados pelo agente, praticados de acordo com o ordenamento jurídico, produzindo efeitos jurídicos voluntários.

José Cretella Júnior define ato jurídico como "toda ação ou omissão lícita do homem que produz efeitos na órbita do direito" 281.

Dispõe o artigo 185 do Código Civil de 2002: “Aos atos jurídicos lícitos, que não sejam negócios jurídicos, aplicam-se, no que couber, as disposições do Título anterior."

No caso das ações humanas, se produzem efeitos jurídicos de acordo com a vontade do agente, são chamadas "negócios jurídicos" (por exemplo, casamento, contrato, testamento); se tais ações humanas produzem efeitos jurídicos, independentemente da vontade do agente, pois seus efeitos estão definidos em lei, está-se diante de atos jurídicos stricto sensu.

\subsubsection{Ato jurídico stricto sensu ou não negocial}

Ato jurídico em sentido estrito é aquele que produz consequências jurídicas previamente definidas em lei, e não pela vontade das partes. Exemplos: fixação e transferência de domicílio, pagamento indevido, percepção de frutos, notificação para constituir o devedor em mora, reconhecimento de filho.

Maria Helena Diniz, ao diferenciar ato jurídico em sentido estrito e negócio jurídico, esclarece:

A doutrina do ato jurídico que, para os alemães, corresponde à dos negócios jurídicos não é romana, embora tenha sido construída por

preciso considerar que a Administração Pública, conquanto muito mais voltada para a edição de atos jurídicos, qualificados como atos administrativos, também pode praticar negócios jurídicos, conforme sucede, por exemplo, quando celebra contratos com particulares. A razão é simples: aqui o objeto contratual será realmente o alvitrado pelas partes (CARVALHO FILHO, 2012a, p. 97-98).

${ }^{281}$ CRETELLA JÚNIOR, 2002, v. 2, p. 11. 
abstração sobre elementos extraídos do direito romano pelos jusnaturalistas, em meados do século XVIII, e por civilistas que, posteriormente, lhe deram maior desenvolvimento, concluindo que a categoria mais importante para o direito é a dos atos lícitos, dentre eles o negócio jurídico. Vivas disputas doutrinárias se digladiaram em torno da compreensão do negócio jurídico, chegando-se a diferenciá-lo do ato jurídico stricto sensu. Entretanto a figura do ato jurídico em sentido estrito permaneceu por muito tempo na penumbra, dado o fato de os juristas concentrarem sua atenção nos negócios jurídicos. Delineou-se o ato jurídico stricto sensu quando a doutrina percebeu, ao elaborar a teoria dos negócios jurídicos, a existência de atos que não se incluíam naqueles $^{282}$.

Assim, observa-se que, no ato jurídico stricto sensu ou não negocial, o efeito da manifestação da vontade está previsto na lei e, dessa forma, não pode ser alterado.

\subsubsection{Negócio jurídico ou ato jurídico negocial}

Ao se falar em negócio jurídico, a primeira ideia que nos vem à mente consiste em uma declaração de vontade destinada à produção de efeitos jurídicos desejados, reconhecidos pelo ordenamento jurídico ${ }^{283}$.

${ }^{282}$ Maria Helena Diniz observa que o direito francês não adotou essa dicotomia, uma vez que o Código de Napoleão tratou a matéria em termos excessivamente genéricos, cuidando apenas do fato jurídico e do ato jurídico, no que foi seguido pelo nosso Código Civil de 1916, de modo que, no direito brasileiro de jure constituto, não se utilizava a expressão "negócio jurídico", embora a definição do artigo 81 fosse, rigorosamente, a de negócio jurídico: “É na disciplina dos negócios jurídicos que o atual Código Civil apresenta maiores alterações em face do Código Civil de 1916, substituindo a expressão genérica ato jurídico, que se encontrava no Código anterior, pela designação específica negócio jurídico, uma vez que é a este e não àquele que se aplicam todas as normas ali constantes, eliminando assim a falta de técnica até então existente. E no que concerne aos atos jurídicos lícitos, que não sejam negócios jurídicos, seguindo o art. 295 do Código Civil português de 1967, abriu-lhes um título da Parte Geral, com um artigo único, o 185, determinando que se lhes apliquem, no que couber, as disposições (CC, arts. 104 a 184) do título anterior" (DINIZ, 2012, v. 1, p. 470-471, grifos da autora).

283 José Cretella Júnior, ao tratar do negócio jurídico administrativo ou negócio administrativo ou ato administrativo negocial, ressalta: “a) [a expressão 'negócio jurídico administrativo'] é ainda discutida, no campo do direito público, embora aceita, há muito, no campo do direito civil; b) é mencionada por todos os doutrinadores italianos, que a formulam, entretanto, de modo diverso, ao mesmo tempo que exemplificam, na prática, essa figura, de modo não-coincidente com a definição dada; c) é inaplicável a expressão negócio jurídico ao ato administrativo, uma vez que neste último a vontade do editor da medida é reduzida a zero, pois o que informa o administrador é a idéia da finalidade, do interesse público, enquanto no negócio jurídico, a força motriz, o elemento determinante da providência é a 'voluntas', o acordo com o particular, pois, sem a anuência deste, inexiste o negócio; d) é reservada, por muitos, a expressão negócio jurídico apenas para o acordo bilateral da Administração com o particular, concretizando-se a operação negocial somente nos acordos em que o Estado, despindo-se de suas prerrogativas de 'puissance publique' (ou potestade pública), celebra horizontalmente contratos de direito civil com o particular (compra, venda, locação, permuta, doação, empreitada, fornecimento contínuo ou descontínuo); e) é inaplicável a expressão negócio jurídico administrativo ao mero ato administrativo, 'stricto sensu', bem como ao contrato de direito público, à concessão (para a exploração de serviço público ou para uso privativo de bem público pelo particular), pois os contratos de direito público estão submetidos a regras especiais de direito público, exorbitantes ou derrogatórias do direito comum, imunes, assim, ao elemento volitivo, elemento este de obrigatória presença, segundo alguns, na constituição do negócio jurídico administrativo" (CRETELLA 
Edmir Netto de Araújo, em seu completo trabalho a respeito do negócio jurídico administrativo, ensina: "Pode-se dizer que negócio jurídico consiste na conjugação de duas ou mais declarações de vontade, preordenadas a, mediante acordo que será instrumentalizado em uma terceira espécie (esta sim, que gera obrigações e direitos, e não as vontades isoladas), produzir os efeitos jurídicos desejados"284.

Washington de Barros Monteiro e Ana Cristina de Barros Monteiro França Pinto apontam duas características do negócio jurídico:

A característica primordial do negócio jurídico é ser um ato de vontade. Precisamente nesse ponto se manifesta sua frontal oposição ao fato jurídico (stricto sensu), que é a resultante de forças naturais em geral; no negócio jurídico, a vontade das partes atua no sentido de obter o fim pretendido, enquanto no ato jurídico lícito o efeito jurídico ocorre por determinação da lei, mesmo contra a vontade das partes. A segunda característica do referido negócio é ser lícito, isto é, fundado em direito. Se se arreda da lei, ou infringe, passa a ilícito. Embora deste advenham também consequências jurídicas, só pode ser incluído entre os fatos jurídicos ${ }^{285}$.

No direito português, segundo Rogério Ehrhardt Soares, negócio jurídico é assim definido:

É o instrumento de eleição no campo do direito privado, onde exprime o reconhecimento do dogma da autonomia da vontade, aceitação de que os particulares dispõem duma total independência na eleição das finalidades que se propõem alcançar e da consequente liberdade de articulação, dentro dos limites da lei, os negócios indispensáveis à construção jurídica do seu mundo ${ }^{286}$.

Trazemos à colação os precisos ensinamentos de Edmir Netto de Araújo:

O Estado pode exprimir vontade negocial, como pessoa jurídica que é, mesmo que essa vontade seja decorrente do que a lei determina ou permite, e seja vinculada ao interesse público, pois o interesse, vinculado ou não, é apenas o móvel da declaração de vontade, e não a própria declaração. É claro que as declarações negociais do Estado, em conjunto com as de outras pessoas e entidades (no contrato, p. ex.), criam uma relação jurídica nova, antes inexistente). [...] Da mesma forma que ocorre nos contratos, existem negócios jurídicos "da Administração" em que esta se coloca em posição de igualdade com o particular, e negócios jurídicos administrativos em que essa igualdade não ocorre, estes últimos sujeitos ao regime jurídico de direito público, com cláusulas de prerrogativas (exorbitantes), se forem contratos ${ }^{287}$.

JÚNIOR, 2002, v. 2, p. 34-35, grifos do autor).

${ }^{284}$ ARAÚJO, 1992, p. 202.

${ }^{285}$ MONTEIRO; PINTO, 2012, v. 1, p. 228.

${ }^{286}$ SOARES, Rogério Guilherme Ehrhardt. Direito administrativo. Coimbra: [s.n.], 1978, p. 17-18.

${ }^{287}$ Edmir Netto de Araújo expõe seu posicionamento sobre o assunto de forma bastante clara: "Finalmente, nossa conhecida posição é de que há atos jurídicos em sentido estrito e lato, nesta última classe colocando-se os contratos, que são uma das espécies dos negócios jurídicos ao lado de outros acordos, todos estes com efeitos produzidos ex voluntate, sejam públicos ou privados, de acordo com o ordenamento jurídico. Ato 
Sendo os contratos em geral espécie de negócio jurídico e transplantando a noção de negócio jurídico para o campo do direito administrativo, adotando o posicionamento defendido por Edmir Netto de Araújo, entende-se que o Estado pode, sim, exprimir vontade negocial, como pessoa jurídica e, portanto, realiza negócio jurídico administrativo.

\subsection{ATO ILÍCITO}

As ações que, embora humanas, violam o direito constituem os chamados atos ilícitos. Ato ilícito é o praticado com infração ao dever legal de não lesar a outrem.

O novo Código Civil regula a matéria sobre ato ilícito nos artigos 186, 187 e 188. A verificação da culpa e a avaliação da responsabilidade ficam a cargo dos artigos 927 a 943 e 944 a 954.

Com muita propriedade, Edmir Netto de Araújo define ilícito:

O ilícito é uma categoria jurídica não exclusiva de qualquer dos ramos do Direito, que compreende toda ação (ou omissão) humana antijurídica, culpável, envolvendo responsabilidade e sanções, e que pode assumir diferentes conotações (penal, civil, trabalhista, tributária, administrativa), conforme a área focalizada ${ }^{288}$.

Para José Cretella Júnior, ilícito "é toda ação ou omissão humana, antijurídica, culpável, que envolve responsabilidades e sanções”. O referido autor ressalta:

A substância ou materialidade do ilícito é sempre um fato que ocasiona um dano, o que gera responsabilidades e sanções, em razão das perturbações causadas ao particular, à sociedade, à Administração ou às pessoas jurídicas privadas. Esses diversos tipos de perturbações e desequilíbrios levaram os diversos setores em que se desdobra a ciência jurídica a se especializarem na apuração das respectivas responsabilidades, com as consequentes aplicações das correspondentes sanções ${ }^{289}$.

São fundamentos do ilícito: fato, dano, responsabilidades (diversas áreas) e sanções. O sujeito passivo pode ser o particular, a sociedade, a Administração ou as pessoas jurídicas privadas.

Ao tratar do ato ilícito como categoria abstrata, Caio Mário da Silva Pereira afirma:

administrativo também existe, espécie que é do ato jurídico, em sentido estrito e lato, nesta última classe incluindo-se contratos e acordos não contratuais em que o Estado aparece em posição de prerrogativa, que, em relação de espécie a gênero, se compreendem na noção de negócio jurídico administrativo, do qual são espécies (entendemos que também existe o negócio jurídico 'da Administração', por coerência lógica)" (ARAÚJO, 1992, p. 201-205, grifos do autor).

${ }^{288}$ ARAÚJO, 1994, p. 27, grifo do autor.

${ }^{289}$ CRETELLA JÚNIOR, José. O Estado e a obrigação de indenizar. Rio de Janeiro: Forense, 1998, p. 43-44, grifos do autor. 
o ato ilícito reúne, na sua etiologia, certos requisitos que podem ser sucintamente definidos: a) uma conduta, que se configura na realização intencional ou meramente previsível de um resultado exterior (Enneccerus); b) a violação do ordenamento jurídico, caracterizada na contraposição do comportamento à determinação de uma norma (Enneccerus); c) a imputabilidade, ou seja, a atribuição do resultado antijurídico à consciência do agente; d) a penetração da conduta na esfera jurídica alheia, pois, enquanto permanecer inócua, desmerece a atenção do direito. Nesta análise cabe toda espécie de ilícito, seja civil, seja criminal. Não se aponta, em verdade, uma diferença ontológica entre um e outro ${ }^{290}$.

Herlado Garcia Vitta assim conceitua ato ilícito:

A conduta (ação ou omissão) que contravém o mandamento da norma, a qual estabelece a consequência jurídica, institucionalizada, organizada normativamente: a sanção. Assim, conforme se vê, apenas quando houver descumprimento do mandamento da norma jurídica, poder-se-á falar em ilícito e sua consequência (a sanção) ${ }^{291}$.

Ao praticar um ato ilícito, comete-se uma infração a um dever de conduta, por meio de ações ou omissões culposas ou dolosas do agente, resultando dano para outrem.

Edmir Netto de Araújo enumera os elementos do ato ilícito: o ato ou omissão humanos, a infringência à norma legal do ramo considerado, o dano e a responsabilidade. E resume: "alguém causa desequilíbrio na ordem natural-legal da sociedade e, pelo seu restabelecimento, deve responder" 292 .

É muito importante ressaltar que não se pode falar em ilicitude em fatos do mundo, somente em atos humanos.

Arnoldo Wald, ao tratar da lesão do direito, discorre sobre o ato ilícito e ressalta:

Ao contrário do negócio jurídico, que é uma declaração de vontade, o ato ilícito é um ato material (ato ou omissão) que, infringindo dever legal ou contratual, causa dano a outrem. Assim, o ato ilícito pressupõe sempre uma relação jurídica originária lesada e a sua consequência é uma responsabilidade, ou seja, o dever de indenizar ou ressarcir o dano causado pelo inadimplemento do dever jurídico existente na relação jurídica originária. O não-cumprimento do dever na relação jurídica, pelo sujeito passivo, implica lesão do direito do sujeito ativo, que pode recorrer ao Estado, a fim de obter não só a prestação, mas, ainda, o ressarcimento dos prejuízos decorrentes do inadimplemento ${ }^{293}$.

\footnotetext{
${ }^{290}$ Tanto no ilícito civil quanto no ilícito criminal, há o mesmo fundamento ético: a infração de um dever preexistente e a imputação do resultado à consciência do agente. Assinala-se, porém, uma diversificação que se reflete no tratamento do agente, quer em função da natureza do bem jurídico ofendido, quer em razão dos efeitos do ato. Para o direito penal, o delito é um fator de desequilíbrio social, que justifica a repressão como meio de restabelecimento; para o direito civil, o ilícito é um atentado contra o interesse privado de outrem, e a reparação do dano sofrido é a forma indireta de restauração do equilíbrio rompido (PEREIRA, Caio Mário da Silva. Instituições de direito civil. 23. ed. Rio de Janeiro: Forense, 2012, v. 1, p. 560, grifos do autor).

${ }^{291}$ VITTA, Heraldo Garcia. A sanção no direito administrativo. São Paulo: Malheiros, 2003, p. 29.

${ }^{292}$ ARAÚJO, 2014, p. 975.

${ }^{293}$ WALD, Arnoldo. Direito civil. 11. ed. São Paulo: Saraiva, 2009, v. 1, p. 273.
} 
A ilicitude pode ser civil (danos à propriedade, prejuízos contratuais), penal (estelionato, furto, homicídio), administrativa (atos danosos, insubordinação, delitos contra a Administração), trabalhista (greves ilegais), contábil (contas mal prestadas ou insuficientemente documentadas, pagamento não autorizado, embora o credor seja legítimo), fiscal (danos ao fisco), financeiro (atividades danosas no campo de operações da bolsa). A ilicitude também pode incidir em outras disciplinas jurídicas, de acordo com a norma jurídica que impõe o dever violado pelo agente, ou seja, vai depender do órgão que impõe a sanção, no exercício de sua função típica ou atípica. Além disso, é possível que o ilícito enquadre-se em mais de um ramo do Direito.

Pode-se dizer que a diferença está no regime jurídico a que a repulsa estiver subordinada.

Regis Fernandes de Oliveira afirma que, se o fato ocorre perante o juízo civil ou penal, a infração será civil ou penal. Haverá sanção administrativa se a apuração da infração resultar de procedimento administrativo, perante autoridade administrativa, sendo a Administração parte interessada em uma relação jurídica deflagrada sob a lei e em que o ato sancionador não tenha força própria de ato jurisdicional, possuindo presunção de legalidade, imperatividade, exigibilidade e executoriedade (quando não vedada por lei). Em suma, o que caracteriza o ilícito administrativo é o fato de estar definido em lei administrativa e sua apuração pertencer a órgão de tal qualificação ${ }^{294}$.

José Cretella Júnior afirma que somente ocorre o problema da responsabilidade quando está presente o ilícito - quer penal, quer civil, quer administrativo, quer contábil -, porque ilicitude é, antes de tudo, quebra ou infração de norma posta ${ }^{295}$, razão pela qual se impõe neste trabalho o estudo da responsabilidade do agente público, em especial do servidor temporário e do ilícito por ele praticado.

\subsubsection{Ilícito administrativo}

Ocorre a prática do ilícito administrativo quando o agente público, no exercício de suas funções, infringir deveres e proibições constantes do regime jurídico ao qual está submetido.

\footnotetext{
294 OLIVEIRA, 2008, p. 146-147.

${ }^{295}$ CRETELLA JÚNIOR, 1998, p. 42.
} 
Observa-se que o ilícito administrativo pode ser praticado pelos agentes públicos, entendendo-se agentes públicos em sentido amplo, incluindo, neste caso, os servidores temporários, objeto de estudo.

Nas palavras de José Cretella Júnior, o ilícito administrativo "é todo ato positivo ou negativo, imputado a agente administrativo, em virtude de infração a dispositivo expresso estatutário"296.

Dependendo da situação, o ilícito administrativo praticado pode ser também um ilícito administrativo penal, deflagrador também da responsabilidade criminal, ou um ilícito administrativo civil, causador da responsabilidade civil.

Edmir Netto de Araújo, transplantando a noção de ato ilícito para o campo do Direito Administrativo, observa:
a ação ou omissão serão imputáveis a agentes administrativos, por infringência a dispositivos estatutários expressos. Em certos casos, o procedimento estará tipificado também em diplomas criminais, geralmente exigindo-se a condição especial de funcionário (agente público) do sujeito ativo. Neste último caso, a responsabilidade do agente será objeto de regime de responsabilidade administrativa estatutária ou especial, mas também do regime penal de responsabilidade, pois seu comportamento extravasa em importância o campo administrativo para ingressar também na esfera penal. As sanções, em consequência, poderão ocorrer em um ou outro campo, ou nos dois, o que é muito comum, pois as figuras definidas como crimes de funcionários, próprios ou não, na lei penal, geralmente encontram o correspondente ilícito administrativo nas disposições estatutárias ${ }^{297}$.

O referido autor ressalta que nem sempre o ilícito administrativo configura uma infração cumulada também como ilícito penal. Há o ilícito administrativo puro, cujo grau de perturbação da ordem jurídica não é tão grave a ponto de a lei penal erigi-lo em infração penal tipificada, protegendo-se apenas o bem jurídico correspondente ao bom funcionamento da Administração. Prossegue:

\footnotetext{
Neste caso, a apuração da responsabilidade e seu julgamento se exaurem na esfera da própria Administração, por intermédio da instauração do respectivo processo administrativo disciplinar. As sanções também serão aquelas previstas nos diplomas legais que disciplinam o regime jurídico desses agentes públicos, não se assemelhando às cominações impostas pelo Código Penal e leis penais especiais. O ilícito administrativo puro, disciplinar (quando atenta contra a hierarquia), ou não disciplinar (quando atenta contra a boa ordem do serviço público, não envolvendo relação de hierarquia e subordinação), deflagrará a responsabilidade do funcionário, atingindo-o nessa qualidade, em maior ou menor grau ${ }^{298}$.
}

\footnotetext{
${ }^{296}$ CRETELLA JÚNIOR, 1998, p. 46.

${ }^{297}$ ARAÚJO, 1994, p. 27

298 ARAÚJO, 1994, p. 28.
} 
Adota-se a classificação de ilícito administrativo proposta por Edmir Netto de Araújo:

a) ilícito administrativo puro disciplinar, que atenta contra os princípios da hierarquia e da subordinação, sem, entretanto, caracterizar qualquer infração penal (insubordinação, p. ex.);

b) ilícito administrativo puro funcional (ou não disciplinar), que fere a boa ordem do serviço público, não envolvendo matéria referente à hierarquia ou à relação de subordinação (participar de gerência, comércio na repartição etc.);

c) ilícito administrativo criminal disciplinar, que envolve comportamentos relacionados à hierarquia, mas também tipificados na lei penal (desobediência, ofensas físicas contra superior, em serviço, etc.);

d) ilícito administrativo criminal funcional (ou não disciplinar) que, tipificado como crime, não constitui, todavia, infração que atenta contra a hierarquia ( $\mathrm{p}$. ex., abandono de cargo, advocacia administrativa etc.) $)^{299}$.

Na sua classificação, Edmir Netto de Araújo apresenta o aspecto substantivo do ilícito administrativo; já o aspecto adjetivo do ilícito refere-se aos meios legais que o Direito coloca à disposição da autoridade pública para promover essa apuração, ou seja, o processo administrativo.

Cretella Júnior aponta, entre deveres e vedações que ocasionam ilícito administrativo puro, que não se eleva à altura do ilícito penal: a assiduidade, a pontualidade, o zelo às coisas públicas, a submissão à inspeção médica, a presteza e a eficiência nos trabalhos de que for incumbido o agente, a denúncia de irregularidades, a decência nos trajes e uniformes, o conhecimento da legislação, o tratamento, na repartição, apenas de assuntos de serviço e o procedimento regular, dentro e fora do serviço ${ }^{300}$.

Em resumo, José Cretella Júnior afirma que há catálogos rígidos de ilícitos penais e há catálogos flexíveis de ilícitos administrativos e explica que os ilícitos penais recebem nomes e definições precisas e os ilícitos administrativos são designados de maneira genérica. Os ilícitos penais caracterizam-se pela tipicidade, e os ilícitos administrativos são marcados pela atipicidade.

\footnotetext{
${ }^{299}$ ARAÚJO, 2014, p. 977.

300 CRETELLA JÚNIOR, 1998, p. 48-49.
} 
Para José Armando da Costa, o direito disciplinar, via de regra, adota o princípio da atipicidade, a menos que se trate de punição grave, em que o princípio da previsibilidade legal, como garantia fundamental do servidor, deve predominar ${ }^{301}$.

Ao cometer um ilícito administrativo, o agente público (incluído o servidor público temporário) deverá ser responsabilizado funcionalmente e disciplinarmente, mediante um processo administrativo, em que seja assegurada a ampla defesa e o contraditório.

\title{
3.4.2 Ilícito penal
}

Ao fazer a diferença entre ilícito penal e ilícito civil, Caio Mário da Silva Pereira afirma: "O direito penal vê no ilícito a razão de punir o agente, o direito civil nele enxerga o fundamento da reparação do dano",302.

A sanção penal é, em geral, a restrição da liberdade da pessoa que praticou o ilícito, mas também pode ser representada por multas ou prestação de serviços à comunidade.

Quando se fala em responsabilidade penal do agente público, os atos ou omissões praticados afetam tanto a Administração quanto a sociedade, há ilícito tanto nas leis penais quanto nas administrativas. É o ilícito administrativo penal que constitui cumulativamente falta grave ou gravíssima e crime ou contravenção, com reflexos nas esferas penal e administrativa $^{303}$.

Edmir Netto de Araújo analisa a questão do ilícito administrativo penal e faz a seguinte diferença:

\begin{abstract}
A tipificação penal deve ser precisa, e o texto legal deve ser interpretado restritivamente, em razão do princípio constitucional da legalidade, que, neste caso, é a legalidade estrita. Entretanto, o seu correspondente administrativo não possui a mesma característica: na verdade, reserva-se à apuração da falta disciplinar uma certa faixa discricionária, que pode ocasionar punições administrativas residuais, mesmo em caso de absolvição no juízo criminal ${ }^{304}$.
\end{abstract}

A responsabilidade penal é pessoal e pretende restabelecer o equilíbrio social perturbado. $\mathrm{O}$ autor do ilícito é colocado em oposição à sociedade. O ilícito caracteriza-se pela tipicidade, ou seja, é o enquadramento da conduta do agente no tipo descrito pela lei penal.

\footnotetext{
${ }^{301}$ COSTA, José Armando da. Processo administrativo disciplinar: teoria e prática. 6. ed. Rio de Janeiro: Forense, 2010, p. 68.

${ }^{302}$ PEREIRA, 2012, v. 1, p. 561.

${ }^{303}$ CRETELLA JÚNIOR, 1998, p. 47-48.

${ }^{304}$ ARAÚJO, 1994, p. 30.
} 


\subsubsection{Ilícito civil}

No plano civil, o ato ilícito importa sempre o dever de indenizar os danos decorrentes da conduta reprovável. Na prática do ilícito administrativo, o agente público pode causar danos a particulares ou ao Poder Público.

Com muita propriedade, Edmir Netto de Araújo afirma: “O fulcro da caracterização do ilícito civil é o dano imputável ao causador, pois, em termos de responsabilidade civil, não há condição de aplicação de uma sistemática de responsabilização, se não há dano” ${ }^{305}$.

Assim, há uma ação humana (ou omissão) antijurídica, culpável, que causa dano ou prejuízo, cuja consequência é a reparação desse dano de forma a restabelecer o equilíbrio econômico da parte prejudicada.

A responsabilidade civil é patrimonial, denominação que José Cretella Júnior entende ser mais apropriada, por envolver o dano, o prejuízo, o desfalque, o desequilíbrio ou a descompensação do patrimônio de alguém ${ }^{306}$.

Basta a ocorrência de um dano para configurar o ilícito civil, não há necessidade de tipificação da ação em qualquer texto legal especial. A relação é a seguinte: autor, dano e vítima.

\subsubsection{Ilícito por ato de improbidade administrativa}

A expressão "improbidade administrativa" é a caracterização atribuída pela Lei n. ${ }^{\circ}$ 8.429/92, conhecida como Lei de Improbidade Administrativa (LIA), a determinadas condutas praticadas por agentes públicos (incluídos os servidores públicos temporários) e também por particulares que nelas tomem parte.

A definição de tais condutas é fornecida pelos artigos 9. ${ }^{\circ}, 10$ e 11 da Lei n. ${ }^{\circ}$ 8.429/92: o artigo 9. ${ }^{\circ}$ define os atos de enriquecimento ilícito, o artigo 10, os atos que acarretam lesão ao erário e o artigo 11, os atos que violam os princípios da administração pública.

A noção de improbidade administrativa derivada da Lei $n{ }^{\circ}$ 8.429/92 é bastante abrangente, modificando qualquer referência legal ou teórica que, anteriormente à edição dessa lei, vinculasse o termo "improbidade" à ideia de desonestidade. Esclarece Márcia Noll Barboza:

\footnotetext{
305 ARAÚJO, 2014, p. 949.

306 CRETELLA JÚNIOR, 1998, p. 41.
} 
A partir da LIA, devemos entender a improbidade administrativa como aquela conduta considerada inadequada - por desonestidade, descaso ou outro comportamento impróprio - ao exercício da função pública, merecedora das sanções previstas no referido texto legal. A LIA adveio como concretização do mandamento inserido no artigo $37, \S 4 .^{\circ}$, da Constituição Federal que assim dispõe: os atos de improbidade administrativa importarão a suspensão dos direitos políticos, a perda da função pública, a indisponibilidade dos bens e o ressarcimento ao erário, na forma e gradação previstas em lei ${ }^{307}$.

Tencionam o dispositivo constitucional e a Lei de Improbidade expressar uma vontade política da sociedade voltada para um adequado gerenciamento da coisa pública. Assim, a Lei n. ${ }^{\circ}$ 8.429/92 visa não apenas os atos de desonestidade, mas também os atos de descaso do agente público para com o interesse público, ou comportamentos igualmente considerados antiéticos.

É importante ressaltar que a improbidade administrativa não é crime. Essa questão, discutida no passado, já está pacificada. A Lei de Improbidade possui natureza cível em sentido amplo, mas possui características próprias. As condutas e sanções que ela estabelece não têm natureza penal, não ficando sujeitas às normas gerais de Direito Penal. Isso não significa que a conduta enquadrável na Lei n. ${ }^{\circ} 8.429 / 92$ não seja, ao mesmo tempo, crime sancionável pelo Código Penal e por outra norma de natureza penal.

Da mesma forma, a improbidade administrativa não se confunde com a falta disciplinar, mas pode haver uma conduta concreta que se amolde à Lei de Improbidade e que, ao mesmo tempo, seja falta disciplinar.

Em geral, da prática do ato ilícito decorre a responsabilidade do agente, mas podese ter responsabilidade mesmo por ato lícito. A responsabilidade pode ocorrer em inúmeros campos da atividade humana. Dependendo da norma jurídica violada, a ilicitude pode ser civil, penal, administrativa ou por improbidade, gerando a responsabilidade civil, penal, administrativa ou por improbidade.

Edmir Netto de Araújo destaca a importância que a responsabilidade do Estado por ato lícito tem ganhado na doutrina brasileira:

independe a responsabilidade da ilicitude dos atos, porque decorre fundamentalmente do dano e do consenso que o respectivo prejuízo deve ser repartido entre a coletividade (justiça social e equidade), elementos que lastreiam a teoria objetiva "sem culpa" da responsabilidade do Estado $^{308}$.

${ }^{307}$ BARBOZA, Márcia Noll. Definição de improbidade administrativa. In BARBOZA, Márcia Noll (Coord.) Cem perguntas e respostas sobre improbidade administrativa: incidência e aplicação da Lei n. 8.429/1992. Brasília, DF: Escola Superior do Ministério Público da União, 2008, p. 13.

${ }^{308}$ ARAÚJO, 2014, p. 846, grifos do autor. 
Assim, voltar-se-ão os estudos para as infrações de regras de condutas relativas ao trabalho dos agentes públicos, em especial do servidor público temporário. Portanto, focalizar-se-ão as atividades por eles desempenhadas no exercício de suas funções, que podem ocasionar a responsabilidade administrativa (responsabilidade disciplinar ou funcional), a responsabilidade civil, a responsabilidade penal e agora a responsabilidade por ato de improbidade administrativa.

\subsection{ESPÉCIES DE RESPONSABILIDADE DOS AGENTES PÚBLICOS}

No desempenho de sua função, o agente público pode, basicamente, sujeitar-se aos seguintes tipos de responsabilidade: penal, civil e administrativa. Atualmente, há a responsabilização pela prática de ato de improbidade administrativa, definida pela Lei n. ${ }^{\circ}$ 8.429/92, possuindo um lugar próprio, não incluso em qualquer outra esfera de responsabilidade.

A relação desenvolvida por Edmir Netto de Araújo é a seguinte: o agente público pode ser responsabilizado por seus atos no campo penal, quando a responsabilidade o atinge como indivíduo inserido na sociedade; no campo civil, quando seus atos causam dano aos particulares administrados ou mesmo ao próprio Estado, incidindo a responsabilidade sobre o seu patrimônio; no campo administrativo, quando a responsabilidade disciplinar enquadra-o na qualidade de agente público ${ }^{309}$.

O desempenho de funções administrativas exporá o agente público a três tipos genéricos de responsabilidade, conforme a natureza da falta por ele praticada: a responsabilidade penal, pela qual o comportamento do agente se enquadra no tipo descrito pela lei penal, no exercício de suas funções ou, em certos casos, até mesmo fora de suas funções, constituindo-se em falta gravíssima, a ser processada tanto pela administração como pelo Poder Judiciário; a responsabilidade civil, quando o ato lesivo vem qualificado pelo elemento subjetivo (dolo ou culpa) do agente público, propiciando ao Estado o poder-dever de contra ele agir regressivamente ou diretamente para o ressarcimento da liquidação do dano causado; e, finalmente, a responsabilidade administrativa ${ }^{310}$.

A Lei n. ${ }^{\circ}$ 8.112/90, em seu artigo 121, estabelece a tríplice responsabilidade do servidor nos seguintes termos: "O servidor responde civil, penal e administrativamente pelo exercício irregular de suas atribuições”.

\footnotetext{
${ }^{309}$ ARAÚJO, 2014, p. 948.

${ }^{310}$ ARAÚJO, 1994, p. 54-55, grifos do autor.
} 
José Cretella Júnior afirma que a figura jurídica da responsabilidade, não obstante una, reparte-se em várias modalidades - a penal, a disciplinar, a civil e, segundo outros, a contábil -, ressaltando que quem está na base de todo problema jurídico é o Homem, em razão do qual se estrutura e se movimenta a ciência do direito ${ }^{311}$.

Defende-se a existência de quatro tipos de responsabilidades do servidor público (incluindo o servidor público temporário) no exercício de suas funções: a responsabilidade penal, a responsabilidade administrativa, a responsabilidade civil e, atualmente, a responsabilidade por ato de improbidade administrativa.

A responsabilidade penal decorre da conduta tipificada pela lei penal como infração penal. É a que decorre da prática de crime, definido por lei. No âmbito penal, a conduta, para gerar a responsabilização, deve ser dolosa ou culposa, afastando-se a responsabilidade objetiva.

O artigo 123 da Lei n. ${ }^{\circ}$ 8.112/90, ao tratar da responsabilidade penal do servidor público, engloba crimes e contravenções: “A responsabilidade penal abrange os crimes e contravenções imputadas ao servidor, nessa qualidade".

Dá-se o nome de crimes contra a Administração Pública aos crimes praticados por agentes públicos no exercício de sua função. Os bens jurídicos protegidos pela norma penal são a normalidade funcional, a probidade, o prestígio e o decoro da Administração Pública.

A responsabilidade penal do servidor público decorre da prática de crimes funcionais $^{312}$, definidos nos artigos 312 a 327 do Código Penal, cujo processo de julgamento perante o Judiciário está previsto nos artigos 513 a 518 do Código de Processo Penal.

O Código Penal prevê outros delitos em que a condição de funcionário público é essencial para o tipo ou a circunstância qualificadora. Exemplos: artigos 150, § 2. ${ }^{\circ}, 297, \S$ 1., 299 , parágrafo único, 300 e 301.

Além dos tipos penais previstos em 1940, foram incluídos outros tipos, como os previstos nos artigos 313-A e 313-B, 359-A e 359-H. A legislação penal esparsa também passou a prever alguns tipos: artigos $3 .^{\circ}$ e $4 .^{\circ}$ da Lei do Abuso de Autoridade (Lei n. ${ }^{\circ}$

\footnotetext{
${ }^{311}$ CRETELLA JÚNIOR, 1998, p. 35.

${ }^{312}$ Crimes funcionais são os crimes contra a Administração Pública praticados por agentes públicos (existem aqueles praticados por particulares, como a corrupção ativa e a sonegação fiscal). A doutrina distingue os crimes funcionais próprios dos crimes funcionais impróprios. Os primeiros são aqueles que têm como elemento essencial a função pública, sem a qual a conduta seria penalmente irrelevante: concussão, excesso de exação, prevaricação, corrupção passiva. Os segundos são aqueles denominados "funcionais" pelo fato de ser o agente um funcionário público; não se revestisse ele dessa qualidade, haveria, não obstante, crime, ainda que não o crime funcional, como o peculato (que nada mais é do que a apropriação indébita praticada em decorrência da função pública).
} 
4.898, de 9 de dezembro de 1965); artigos 89 a 98 da Lei de Licitações (Lei n. ${ }^{\circ}$ 8.666, de 21 de junho de 1993); artigo 3. ${ }^{\circ}$ da Lei dos crimes contra a ordem tributária (Lei n. ${ }^{\circ} 8.137$, de 27 de dezembro de 1990); artigos 66 e 67 da Lei que dispõe sobre as sanções penais e administrativas derivadas de condutas e atividades lesivas ao meio ambiente (Lei n. ${ }^{\circ}$ 9.605, de 12 de fevereiro de 1998); artigo $1 .^{\circ}$ e $§ 4 .^{\circ}$ da Lei que define os crimes de tortura (Lei n. ${ }^{\circ}$ 9.455, de 7 de abril de 1997); artigos 289 a 354 do Código Eleitoral (Lei n. ${ }^{\circ}$ 4.737, de 12 de julho de 1965); Código Penal Militar.

Trata-se de crimes de ação penal pública, e é de competência exclusiva do Ministério Público o desencadear da ação penal, promovida por denúncia, cuja iniciativa poderá ser provocada por qualquer pessoa do povo que forneça, por escrito, informações sobre o fato e a autoria, indicando o tempo, o lugar e os elementos de convicção.

Os agentes públicos podem praticar, no exercício de suas funções, outros crimes comuns, inclusive de ação penal privada ou de ação penal pública condicionada, também respondendo penalmente por suas ações.

Maria Sylvia Zanella Di Pietro enumera as peculiaridades do ilícito penal, quando um servidor responde penalmente pela prática de crime ou contravenção:

1. a ação ou omissão deve ser antijurídica e típica, ou seja, corresponder ao tipo, ao modelo de conduta definido na lei penal como crime ou contravenção; 2. dolo ou culpa, sem possibilidade de haver hipótese de responsabilidade objetiva; 3 . relação de causalidade; 4 . dano ou perigo de dano: nem sempre é necessário que o dano se concretize; basta haver o risco de dano, como ocorre na tentativa e em determinados tipos de crime que põem em risco a incolumidade pública ${ }^{313}$.

Diogenes Gasparini, ao tratar da responsabilidade penal, esclarece:

Implica a condenação penal o reconhecimento da responsabilidade civil e da responsabilidade administrativa, se decorrentes do mesmo ato, vez que a infração penal funcional é mais que suas congêneres. [...] Alerte-se, no entanto, que a condenação no âmbito criminal, por si só, não enseja punição administrativa. Aquela somente dá ensejo a esta se a infração também for havida como ilícito administrativo ${ }^{314}$.

No ilícito penal, o autor é colocado em oposição à sociedade. No direito penal, fazse necessário definir de forma exata no direito positivo o comportamento condenado pela sociedade. Trata-se do princípio da tipicidade, que é o enquadramento da conduta do agente no tipo descrito pela lei penal. A ação penal não depende da responsabilização ou

\footnotetext{
${ }^{313}$ DI PIETRO, 2013, p. 675, grifos da autora.

${ }^{314}$ GASPARINI, 2012, p. 296.
} 
não em outra esfera, em decorrência dos princípios da oficialidade ${ }^{315}$ e da indisponibilidade ${ }^{316}$.

Ao praticar um ilícito administrativo definido na legislação estatutária, o servidor está sujeito à responsabilidade administrativa.

Nas palavras de Hely Lopes Meirelles, a responsabilidade administrativa "resulta da violação de normas internas da Administração, pelo servidor sujeito ao Estatuto e disposições complementares, estabelecidas em lei, decreto ou qualquer outro provimento regulamentar da função pública"317.

Edmir Netto de Araújo apresenta o conceito de responsabilidade administrativa em sentido amplo e em sentido estrito:

Assim, em sentido amplo, responsabilidade administrativa é aquela à qual está sujeito o agente público por qualquer ato praticado no exercício de suas atribuições legais (e, em certos casos, até mesmo fora delas), infringente das normas administrativas, podendo ocorrer ou não a qualificação penal adicional e, não raro, a responsabilidade patrimonial (civil) decorrente. Já em sentido estrito, significa a obrigação de responder perante a Administração pela prática de ilícito administrativo na infração de regras de conduta relacionadas à função pública, desdobrando-se em ilícito disciplinar e funcional ${ }^{318}$.

Para o referido autor, quando a falta estiver relacionada à hierarquia, haverá responsabilidade disciplinar propriamente dita. Exemplo: falta por desobediência a ordem não manifestamente ilegal de superior hierárquico. Do contrário, se a falta for um ilícito administrativo, não relacionado à hierarquia, há responsabilidade administrativa não disciplinar ou funcional, visto que se refere à conduta do agente, mas está relacionada apenas a sua função ou atribuições, sem estar vinculada ao poder hierárquico ou disciplinar. Como exemplo, cita-se a infração por não assiduidade e pontualidade no serviço ou por falta de urbanidade com os companheiros de serviço ou os administrados, em seu atendimento ${ }^{319}$.

O ilícito administrativo puro, ou seja, quando inexiste a tipificação penal para o comportamento do agente, terá a responsabilidade apurada na esfera administrativa.

Tal responsabilização tem por objetivo a tutela e a proteção da ordem interna dos serviços, do bom funcionamento da máquina administrativa, ou seja, do serviço público.

\footnotetext{
${ }^{315}$ Diante de uma infração, o Estado, por intermédio do Ministério Público, deve agir de ofício, promovendo a ação penal.

${ }^{316} \mathrm{O}$ Ministério Público não pode dispor da ação penal que pertence ao Estado.

${ }^{317}$ MEIRELLES, 2012, p. 555.

${ }^{318}$ ARAÚJO, 1994, p. 55-56, grifos do autor.

319 ARAÚJO, 1994, p. 56.
} 
A responsabilidade administrativa deve ser apurada pela própria Administração Pública mediante processo administrativo, sendo assegurada ao servidor ampla defesa e contraditório, nos termos do artigo 5. ${ }^{\circ}, \mathrm{LV}$, da Constituição Federal.

Comprovada a prática do ilícito administrativo pelo servidor, será aplicada a sanção correspondente. A responsabilidade administrativa do agente público decorre de sua submissão ao poder sancionatório disciplinar do Estado.

Adverte Maria Sylvia Zanella Di Pietro que não há, com relação ao ilícito administrativo, a mesma tipicidade que caracteriza o ilícito penal.

A maior parte das infrações não é definida com precisão, limitando-se a lei, em regra, a falar em falta do cumprimento dos deveres, falta de exação no cumprimento do dever, insubordinação grave, procedimento irregular, incontinência pública; poucas são as infrações definidas, como abandono de cargo ou os ilícitos que correspondem a crimes ou contravenções. Isso significa que a Administração dispõe de certa margem de apreciação no enquadramento da falta dentre os ilícitos previstos em lei, o que não significa possibilidade de decisão arbitrária, já que são previstos critérios a serem observados obrigatoriamente ${ }^{320}$

É importante a motivação da penalidade imposta para demonstrar adequação entre a infração e a pena escolhida e impedir o arbítrio da Administração.

Em razão disso, Edmir Netto de Araújo chega a dizer que a infração disciplinar é atípica, concluindo pela desnecessidade da rigorosa anterioridade da lei "tipificando" a conduta e mesmo de uma relação taxativa de faltas que possam ser punidas como ilícito administrativo, reservando-se uma larga faixa discricionária ao superior hierárquico na apreciação da falta disciplinar ${ }^{321}$.

Quando o servidor público, dolosamente ou culposamente, por um comportamento comissivo ou omissivo, causa um dano à Administração ou a um terceiro, surge a obrigação de reparar o dano, gerando a responsabilidade subjetiva ou com culpa, ou seja, a responsabilidade civil.

A responsabilidade civil do servidor público é a que decorre da prática ou da omissão, dolosa ou culposa, de atos e fatos que lhe são atribuídos e que causaram um dano à entidade a que se liga ou a terceiro. É essencial, para sua caracterização, que o comportamento desse servidor seja doloso ou culposo e determinante do dano patrimonial causado à entidade a que está vinculado ou a terceiro. Sem tal comportamento e sem a

\footnotetext{
${ }^{320}$ DI PIETRO, 2013, p. 674.

${ }^{321}$ ARAÚJO, 2014, p. 950-951.
} 
ocorrência do dano, não se pode falar em responsabilidade civil. Não se trata, pois, de responsabilidade objetiva. É a aplicação do disposto no artigo 186 do Código Civil ${ }^{322}$.

Maria Sylvia Zanella Di Pietro, após afirmar que a responsabilidade civil é de ordem patrimonial, analisa o artigo 186 do Código Civil e verifica que, para configurar-se o ilícito civil, exige-se:

\section{1. ação ou omissão antijurídica;}

2. culpa ou dolo; com relação a este elemento, às vezes de difícil comprovação, a lei admite alguns casos de responsabilidade objetiva (sem culpa) e também de culpa presumida; uma e outra constituem exceções à regra geral de responsabilidade subjetiva, somente sendo cabíveis diante de norma legal expressa;

3. relação de causalidade entre a ação ou omissão e o dano verificado;

4. ocorrência de um dano material ou moral ${ }^{323}$.

Os conceitos de culpa ou dolo são os utilizados pelo Direito Privado. A culpa pressupõe imprudência, imperícia, negligência ou imprevisão. O dolo requer a prática consciente de um ato que sabe ser contrário ao Direito.

A responsabilidade civil objetiva a reparação ou o ressarcimento de um dano, o pagamento de uma indenização, é uma responsabilidade patrimonial, não se trata de aplicação de sanção. Assim, diferentemente das esferas penal e administrativa, para a responsabilidade civil não se fala em sanção ou penalidade, apenas em reparação do dano.

Quanto à responsabilidade civil do agente público, Edmir Netto de Araújo faz a seguinte divisão:

Quando o prejuízo é causado pelo servidor, agindo nessa qualidade, a particular, o regime de responsabilidade para a composição do dano é o da responsabilidade do Estado, com regressividade contra o servidor, nos termos do art. 37 da Constituição Federal vigente. Sistemática diferente, entretanto, é adotada quando o servidor causa algum prejuízo diretamente ao Estado, no desempenho de suas funções ${ }^{324}$.

Assim, observa-se a existência de duas situações: 1) dano causado pelo agente público ao administrado: aplica-se o regime da responsabilidade do Estado, com regressividade contra o servidor, nos termos do artigo 37 da Constituição Federal - nesse caso, o Estado é obrigado a ressarcir o prejuízo, cobrando regressivamente do servidor; 2) dano causado pelo agente público ao Estado: aplica-se o regime de responsabilidade civil do servidor, com a responsabilização do servidor em virtude da prática de ilícito

\footnotetext{
${ }^{322}$ GASPARINI, 2012, p. 298.

${ }^{323}$ DI PIETRO, 2012, p. 672.

${ }^{324}$ ARAÚJO, 2014, p. 968.
} 
administrativo - há responsabilidade civil, penal, administrativa e por ato de improbidade administrativa.

No primeiro caso, quando o servidor público causa danos a terceiros no exercício de suas funções ou a pretexto de exercê-las, aplica-se o artigo $37, \S 6 .^{\circ}$, da Constituição Federal - responsabilidade objetiva do Estado (não é preciso provar dolo ou culpa); uma vez paga a indenização a que o servidor foi condenado, instaura-se uma ação de regresso contra o servidor causador do dano, dependendo da comprovação de sua culpa ou dolo.

No segundo caso, apura-se a responsabilidade pela própria Administração, mediante o competente processo administrativo, em que se deve dar ao servidor público acusado amplo direito de defesa, consoante exige o inciso LV do artigo 5. ${ }^{\circ}$ da Constituição Federal. Uma vez apurada a responsabilidade e fixado o valor da indenização, cabe ao servidor o pagamento, que pode ser satisfeito de uma só vez, ou em parcelas descontadas mensalmente dos seus vencimentos, se dessa forma estiver previsto em lei e segundo um percentual máximo, também fixado em lei.

A discussão gira em torno da necessidade ou não do consentimento do servidor para o desconto mensal dos seus vencimentos. Para alguns autores, o desconto só é possível se com ele o servidor concordar, sob pena de ser verdadeira penhora ex officio nos vencimentos. Para outros, o desconto dos vencimentos, desde que previsto em lei, é perfeitamente válido e não depende do consentimento do servidor, inserindo-se entre as hipóteses de autoexecutoriedade dos atos administrativos ${ }^{325}$.

Destacam-se os artigos 927, 934 e 942 do Código Civil em matéria de responsabilidade civil por atos ilícitos:

Art. 927. Aquele que, por ato ilícito (arts. 186 e 187), causar dano a outrem, fica obrigado a repará-lo.

Art. 934. Aquele que ressarcir o dano causado por outrem pode reaver o que houver pago daquele por quem pagou, salvo se o causador do dano for descendente seu, absoluta ou relativamente incapaz.

Art. 942. Os bens do responsável pela ofensa ou violação do direito de outrem ficam sujeitos à reparação do dano causado; e, se a ofensa tiver mais de um autor, todos responderão solidariamente pela reparação.

No âmbito da Lei n. ${ }^{\circ} 8.112 / 90$, a responsabilidade civil do servidor público é tratada da seguinte maneira:

\footnotetext{
${ }^{325}$ São favoráveis a que o desconto só seja possível se com ele o servidor concordar: Diógenes Gasparini (2012, p. 299) e José dos Santos Carvalho Filho (2012a, p. 758). O Supremo Tribunal Federal possui esse entendimento, conforme MS 24182/DF (Rel. Min. Maurício Corrêa. Julgamento: 12 fev. 2004). Maria Sylvia Zanella Di Pietro, por sua vez, defende que o "desconto dos vencimentos, desde que previsto em lei, é perfeitamente válido e não depende do consentimento do servidor, inserindo-se entre as hipóteses de autoexecutoriedade dos atos administrativos" (2013, p. 673).
} 
Art. 122. A responsabilidade civil decorre de ato omissivo ou comissivo, doloso ou culposo, que resulte em prejuízo ao erário ou a terceiros.

$\S 1 .^{\circ}$ A indenização de prejuízo dolosamente causado ao erário somente será liquidada na forma prevista no art. 46, na falta de outros bens que assegurem a execução do débito pela via judicial.

$\S 2 .^{\circ}$ Tratando-se de dano causado a terceiros, responderá o servidor perante a Fazenda Pública, em ação regressiva.

$\S 3 .^{\circ}$ A obrigação de reparar o dano estende-se aos sucessores e contra eles será executada, até o limite do valor da herança recebida.

Art. 124. A responsabilidade civil-administrativa resulta de ato omissivo ou comissivo praticado no desempenho do cargo ou função.

Assim, a responsabilidade civil refere-se à responsabilidade patrimonial, em oposição à responsabilidade penal, que é pessoal.

Atualmente, há um outro tipo de responsabilidade, que é a responsabilidade por ato de improbidade administrativa. Pode-se dizer que, em vez de uma trilogia, haveria uma "tetralogia" da responsabilidade do agente público.

A responsabilidade do agente público por ato de improbidade administrativa, por força do disposto no artigo 37, § 4. ${ }^{\circ}$, da Constituição da República e na Lei de Improbidade Administrativa $^{326}$ (Lei n. ${ }^{\text { }}$ 8.429, de 2 de junho de 1992, artigos 16 a 18), atinge todo aquele que, exercendo - ainda que transitoriamente ou sem remuneração por eleição, nomeação, designação, contratação ou qualquer outra forma de investidura ou vínculo mandato, cargo ou emprego ou função administrativa em qualquer ente ou poder estatal, praticar ato de improbidade administrativa ficará sujeito à responsabilização administrativa, civil e penal. Sob o aspecto civil, poderá ser decretado pelo juiz o sequestro de bens e também o bloqueio de bens, contas bancárias e aplicações financeiras mantidas no exterior.

É dever de todos os agentes públicos exercer suas atividades com honestidade, lealdade, isenção e ética, visando à realização do interesse público e do bem comum. $\mathrm{O}$ agente público não pode aproveitar-se de sua posição funcional transitória para obter vantagens pessoais ou beneficiar terceiros.

Apesar disso, são encontradas irregularidades administrativas em todas as partes do Brasil e do mundo. Todos os dias, observam-se inúmeros casos de desvio de bens,

\footnotetext{
326 "Art. $10^{\circ}$ Os atos de improbidade praticados por qualquer agente público, servidor ou não, contra a administração direta, indireta ou fundacional de qualquer dos Poderes da União, dos Estados, do Distrito Federal, dos Municípios, de Território, de empresa incorporada ao patrimônio público ou de entidade para cuja criação ou custeio o erário haja concorrido ou concorra com mais de cinqüienta por cento do patrimônio ou da receita anual, serão punidos na forma desta lei. Parágrafo único. Estão também sujeitos às penalidades desta lei os atos de improbidade praticados contra o patrimônio de entidade que receba subvenção, benefício ou incentivo, fiscal ou creditício, de órgão público bem como daquelas para cuja criação ou custeio o erário haja concorrido ou concorra com menos de cinqüenta por cento do patrimônio ou da receita anual, limitandose, nestes casos, a sanção patrimonial à repercussão do ilícito sobre a contribuição dos cofres públicos”.
} 
subtração de valores gastos indevidamente de dinheiro público, principalmente em obras, compras e serviços ${ }^{327}$.

A Constituição Federal de 1988 prevê vários sistemas de controle da moralidade administrativa, inclusive da probidade. $\mathrm{O}$ artigo $37, \S 4 .^{\circ}$, da Constituição Federal dispõe: “os atos de improbidade administrativa importarão a suspensão dos direito políticos, a perda da função pública, a indisponibilidade dos bens e o ressarcimento ao erário, na forma e gradação prevista em lei, sem prejuízo da ação penal cabível”.

Além disso, nos termos do artigo 14, § 9. ${ }^{\circ}$, da Constituição Federal, cabe à lei complementar estabelecer, além dos casos previstos no seu próprio texto (artigo 14, § 7. ${ }^{\circ}$ ), outros motivos de inelegibilidade e os prazos de sua cessação, a fim de proteger a probidade administrativa, a moralidade para o exercício de mandato, considerando-se a vida pregressa do candidato e a normalidade e legitimidade das eleições contra a influência do poder econômico ou o abuso do exercício de função, cargo ou emprego na administração direita ou indireta.

Aliás, nos termos do artigo 85, V, da Constituição Federal, atentar contra a "probidade na administração" é hipótese prevista como crime de responsabilidade do Presidente da República, fato que enseja sua destituição do cargo.

A palavra "improbidade" vem do latim improbitate, com o sentido de desonestidade $^{328}$. Probidade é, pois, sinônimo de honestidade. Este é o termo-chave para a formulação do conceito. Probidade administrativa significa honestidade no desempenho da atividade administrativa do Estado.

Segundo consta do verbete no Dicionário Houaiss da língua portuguesa, "probidade administrativa" quer dizer integridade, honestidade no tratamento da coisa pública, por parte dos administradores e funcionários públicos $[1]^{329}$.

José Roberto Pimenta Oliveira entende que probidade é demonstração de integridade de caráter ou retidão. Falar de probidade de determinado agente público é reportar-se à sua integridade de caráter e retidão, o que conduz a avaliar sua honestidade no exercício da função pública ${ }^{330}$.

\footnotetext{
${ }^{327}$ MARQUES, Silvio Antonio. Improbidade administrativa. São Paulo: Saraiva, 2010, p. 25.

328 FIGUEIREDO, Marcelo. Probidade administrativa: comentários à Lei 8.429/82 e legislação complementar. São Paulo: Malheiros, 2009, p. 47-51.

${ }^{329}$ DICIONÁRIO eletrônico Houaiss da língua portuguesa. [S.1.]: Objetiva, 2009. 1 CD-ROM.

${ }^{330}$ OLIVEIRA, José Roberto Pimenta. Improbidade administrativa e sua autonomia constitucional. Belo Horizonte: Fórum, 2009, p. 172.
} 
A Lei n. ${ }^{\circ}$ 8.429/92 enumera três espécies de improbidade administrativa: enriquecimento ilícito no exercício de função pública, prejuízo patrimonial ao erário e atentado aos princípios da Administração Pública.

Destacam-se na primeira espécie de atos ímprobos a aquisição de bens de valor desproporcional à evolução do patrimônio ou renda do agente público, além do recebimento de vantagem indevida em razão do exercício de função pública; na segunda espécie, há a presunção de lesividade das hipóteses ali previstas; na terceira, a relevância de atos que não necessariamente causam prejuízo patrimonial, mas que nocivamente violam princípios e regras ${ }^{331}$.

A violação da probidade administrativa implica a imposição de sanções típicas (perda de bens ou valores acrescidos, perda da função pública, suspensão dos direitos políticos, pagamento de multa civil, ressarcimento do dano e proibição de contratar com o Poder Público ou de receber benefícios ou incentivos fiscais ou creditícios) e atípicas (declaração de nulidade ou ineficácia, prestação de atividade devida ou cessação de atividade nociva etc.), aplicáveis por meio de ação civil pública promovida pelo Ministério Público ou pela entidade lesada, no juízo cível, e sem prejuízo de outras sanções civis, administrativas ou criminais, pelo rito ordinário, segundo a tutela dos interesses metaindividuais, não havendo prerrogativa de foro em razão da função pública.

Ressalte-se que as sanções são cumulativas. Além disso, as sanções que visam a reparação de danos são imprescritíveis, conforme artigo $37, \S 5^{\circ}{ }^{\circ}$, da Constituição Federal.

A Lei n. ${ }^{\circ}$ 8.429/92, inovando o sistema de controle da Administração Pública, institui a espécie de ato de improbidade administrativa que atenta contra os princípios da administração pública; lista, como correlatos aos princípios, os deveres do administrador, no caput do artigo 11.

$\mathrm{Na}$ visão de Eurico Bitencourt Neto, em termos conceituais, moralidade administrativa é expressão mais ampla que probidade administrativa: esta inclui-se naquela. Nem todo ato imoral será também desonesto. A moralidade administrativa seria um conjunto de regras morais aplicadas ao exercício da função administrativa do Estado, que, refletindo a moral vigente na sociedade, constitui-se em círculo específico de relações sociais, o da Administração Pública. Em outras palavras, a moralidade administrativa indica o correto uso de competências, segundo o padrão moral-administrativo vigente, para a obtenção da finalidade pública ${ }^{332}$.

\footnotetext{
${ }^{331}$ MARTINS JÚNIOR, Wallace Paiva. Probidade administrativa. 4 .ed. São Paulo: Saraiva, 2009. p. 512-514.

${ }^{332}$ BITENCOURT NETO. Eurico. Improbidade administrativa e violação de princípios. Belo Horizonte: Del
} 
Segundo Wallace Paiva Martins Júnior, o princípio da probidade administrativa é efetivamente decorrência do princípio da moralidade administrativa e é informado pelos mesmos valores que incidem neste, mas adquire contornos próprios, por sua função instrumentalizadora da moralidade administrativa, desempenhando uma atuação sensível de garantia da eficácia dos princípios da Administração Pública. Para o agente público, surge como ônus ou dever de boa administração, exigindo que os atos por ele praticados demonstrem sua habilitação moral guiada pelo senso ético no exercício de cargo, função ou emprego público ${ }^{333}$.

O referido autor ressalta que a norma constitucional criou um subprincípio ou uma regra derivada do princípio da moralidade administrativa: a probidade administrativa, que assume paralelamente as características de um direito subjetivo público a uma Administração Pública proba e honesta, influenciado pela conversão instrumentalizada de outros princípios da Administração Pública (notadamente, a impessoalidade, a lealdade, a imparcialidade, a publicidade e a razoabilidade) e pelo cumprimento do dever de boa administração.

Wallace Paiva Martins Júnior destaca que a imparcialidade, a honestidade e a lealdade vinculam-se, necessariamente, aos conceitos de moralidade e de $\operatorname{probidade}^{334}$.

José Afonso da Silva chama "ato de improbidade administrativa" a imoralidade administrativa qualificada pelo dano ao erário e correspondente vantagem conferida ao ímprobo ou a outrem ${ }^{335}$.

Maria Sylvia Zanella Di Pietro entende que, como princípios, a moralidade e a probidade administrativas confundem-se; como infração, a improbidade é mais ampla do que a imoralidade, porque a lesão ao princípio da moralidade constitui uma das hipóteses de atos de improbidade definidos em lei ${ }^{336}$.

Marcelo Figueiredo destaca a dificuldade de estabelecer contornos nítidos para a noção de probidade administrativa. Aduz que a probidade é espécie do gênero moralidade administrativa; a ofensa à probidade será também atentado à moralidade. Em suma, demonstra a dificuldade de se pretender estabelecer, com exatidão, o alcance de cada uma. Pode-se dizer que é impossível delimitar, com exatidão e a priori, o sentido de cada um

Rey, 2005, p. 102-105.

${ }^{333}$ MARTINS JÚNIOR, 2009, p. 106-107 e p. 114.

${ }^{334}$ MARTINS JÚNIOR, 2009, p. 101-119.

${ }^{335}$ SILVA, José Afonso da. Curso de direito constitucional positivo. 32. ed. São Paulo: Malheiros, 2009, p. 669.

${ }^{336}$ DI PIETRO, 2013, p. 887-888. 
dos princípios da Administração Pública, incluídos os de moralidade e de probidade. Já se mencionou que não possuem âmbito estanque ${ }^{337}$.

$\mathrm{Na}$ visão de Emerson Garcia e Rogério Pacheco, a moralidade administrativa envolve os ditames de justiça, dignidade, honestidade, lealdade e boa-fé ${ }^{338}$.

Marcelo Figueiredo, do mesmo modo, entende que os deveres de honestidade e de lealdade são partes do conceito de moralidade administrativa ${ }^{339}$.

A Lei n. ${ }^{\circ}$ 8.429/92 consagrou um conceito amplo de honestidade administrativa, no sentido de que a conduta parcial ou desleal será desonesta em relação ao interesse público, cujo sentido se extrai do conjunto do sistema jurídico. Em outras palavras, desonestidade administrativa significa ausência de decoro e de dignidade na execução da atividade administrativa do Estado; não é necessária a presença do desvio de recursos financeiros ${ }^{340}$.

Para José Roberto Pimenta Oliveira, “como princípios, há separação entre moralidade e probidade. A origem da distinção é constitucional (artigo 37, caput e artigo $37, \S 4 .^{\circ}$ ), encontrando acolhimento na legislação infraconstitucional”341 ${ }^{\text {. }}$

De outra parte, em concepção enraizada em nosso direito positivo, alguns entendem que, como infração a dever legalmente previsto na Lei Federal no 8.429/92, a improbidade administrativa é mais ampla que a imoralidade, já que, no texto legal mencionado, a ofensa ao princípio de moralidade administrativa é apenas uma das hipóteses de atos de improbidade.

Sobre a questão, afirma Flávio Sátiro Fernandes: “a) moralidade e probidade administrativas são noções bem claramente distintas, que se não podem confundir ante os textos legais que, a partir da Constituição Federal, a elas se referem; b) por esses mesmos textos, é forçoso reconhecer [...] que a probidade é que é o gênero, do qual a moralidade é

\footnotetext{
${ }^{337}$ FIGUEIREDO, 2009, p. 47-51.

${ }^{338}$ GARCIA, Emerson; ALVES, Rogério Pacheco. Improbidade administrativa. 4. ed. Rio de Janeiro, Lumen Juris, 2008, p. 75.

${ }^{339}$ FIGUEIREDO, 2009, p. 105.

340 BITENCOURT NETO, 2005, p. 122-123.

${ }^{341} \mathrm{O}$ referido autor afirma que a diferenciação entre os princípios básicos de moralidade e de probidade aparece agasalhada na Lei Geral de Licitações e Contratos da Administração (Lei n. ${ }^{\circ}$ 8.666/93, artigo 3. ${ }^{\circ}$ ). A Lei Geral do Processo Administrativo da Administração Pública Federal também reconhece o princípio da moralidade (artigo 2..$^{\circ}$ ), tornando critério obrigatório nos processos administrativos a atuação segundo padrões éticos de probidade, decoro e boa-fé (artigo 2. ${ }^{\circ}$, parágrafo único, IV), atendimento a fins de interesse geral (artigo 2. ${ }^{\circ}$, parágrafo único, II), objetividade no atendimento do interesse público (artigo $2 .^{\circ}$, parágrafo único, III). O Regime Jurídico Único da Administração Federal Direta e Autárquica (Lei n. ${ }^{\circ}$ 8.112/90) consigna o dever do servidor de ser leal às instituições a que servir (artigo 116, II) e de manter conduta compatível com a moralidade administrativa (artigo 116, IX) (OLIVEIRA, 2009, p. 173).
} 
espécie, haja vista a maior amplitude e o maior alcance emprestados à primeira, pela Constituição Federal e pela legislação ordinária"342.

Ao contrário de Flávio Sátiro Fernandes, defende-se aqui a corrente que entende que a moralidade administrativa é gênero, sendo a probidade administrativa espécie de moralidade administrativa, em razão da própria disposição dos artigos na Constituição Federal (caput e parágrafo).

A responsabilidade por atos de improbidade administrativa tem por objeto a proteção do patrimônio público.

Assim, observa-se que o agente público está sujeito à responsabilidade civil, penal, administrativa e por ato de improbidade. Por sua vez, como o servidor público temporário é espécie de servidor público, ele submete-se a todos os tipos de responsabilidades que foram estudados.

\subsection{INDEPENDÊNCIA DAS INSTÂNCIAS DE RESPONSABILIZAÇÃO CIVIL, PENAL, ADMINISTRATIVA E POR ATO DE IMPROBIDADE}

De acordo com a natureza da norma jurídica, haverá determinado tipo de responsabilidade: se a norma tem natureza penal, a consumação do fato gerador conduz à responsabilidade penal; se a norma é de direito civil, implica responsabilidade civil; se for praticado um ato de improbidade, o agente estará sujeito à responsabilidade por ato de improbidade; finalmente, se o fato estiver previsto em norma administrativa, gerará a responsabilidade administrativa.

Partindo-se do pressuposto de que as normas jurídicas acima referidas são autônomas entre si, as responsabilidades também serão, em princípio, independentes. Por isso, conclui José dos Santos Carvalho Filho: "A responsabilidade civil não acarreta, necessariamente, a responsabilidade penal e a administrativa; esta última, por sua vez, independe da civil e da penal”. E exemplifica:

uma infração administrativa de impontualidade de um servidor causa a sua responsabilidade administrativa, mas não implica sua responsabilidade penal, porque não foi violada norma dessa natureza. Por outro lado, se o indivíduo causa dano a outrem, agindo com negligência, tem responsabilidade civil, mas não penal nem administrativa, vez que sua conduta só vulnerou norma de caráter civil ${ }^{343}$.

\footnotetext{
${ }^{342}$ FERNANDES, Flávio Sátiro. Improbidade administrativa. Revista de Direito Administrativo, Rio de janeiro, n. 210, out./dez. 1997, p. 172.

${ }^{343}$ CARVALHO FILHO, 2012a, p. 542.
} 
José dos Santos Carvalho Filho chama a atenção para o fato de que podem, eventualmente, conjugar-se as responsabilidades, mas isso só vai ocorrer se a conduta violar, simultaneamente, normas de naturezas diversas. $\mathrm{O}$ autor cita a seguinte situação: no crime de peculato (artigo 312 do Código Penal), por exemplo, o servidor que se apropria indevidamente de bem público sob sua custódia tem, cumulativamente, responsabilidade penal, civil e administrativa, porquanto sua conduta violou, simultaneamente, esses três tipos de norma.

Em decorrência da responsabilidade administrativa, haverá íntima relação, quanto aos efeitos e repercussões, com a responsabilidade penal, a responsabilidade civil e a responsabilidade por atos de improbidade administrativa.

Para Edmir Netto de Araújo, a responsabilidade administrativa geralmente precede a responsabilidade penal e a civil, pois as duas últimas responsabilidades (civil e penal) são decorrentes de atos do agente público no desempenho de suas funções, demandando a apuração administrativa do que ocorreu ${ }^{344}$.

Depreende-se da regra do non bis in idem que ninguém poderá ser penalizado duas vezes pela mesma infração, pelo mesmo fato.

Ocorre que os diplomas estatutários - por exemplo, Lei federal n. ${ }^{\circ} 8.112 / 90$, artigos 121 a 126, Lei estadual paulista . $^{\circ} 10.261 / 68$, artigos 245 a 250, Lei municipal paulista n. ${ }^{\circ}$ 8.989/79, artigos 180 a 183 - contêm disposições no sentido de que a responsabilidade disciplinar do servidor não depende da responsabilidade civil ou criminal. Isso quer dizer que o servidor pode ter uma tríplice (ou tetra) responsabilidade pelo mesmo fato, responderá civil, penal e administrativamente e também quanto à improbidade administrativa.

José Cretella Júnior apresenta a seguinte conclusão sobre a independência das instâncias:

[...] a responsabilidade disciplinar é completamente diferente da responsabilidade penal, e também da responsabilidade civil, notando-se ainda que a responsabilidade disciplinar, decorrente da hierarquia, atinge o funcionário público, ao passo que a responsabilidade penal, além de atingir o funcionário público, atinge qualquer cidadão ${ }^{345}$.

Visto que as responsabilidades podem acumular-se, é possível a acumulação das sanções, pois cada tipo de responsabilidade recebe uma sanção. Tal preceito está materializado no artigo 125 da Lei n. ${ }^{\circ}$ 8.112/90: “as sanções civis, penais e administrativas

\footnotetext{
${ }^{344}$ ARAÚJO, 2014, p. 822.

${ }^{345}$ CRETELLA JÚNIOR, 1998, p. 40, grifos do autor.
} 
poderão cumular-se, sendo independentes entre si”. O Supremo Tribunal Federal já se manifestou pela independência das responsabilidades e, em consequência, das respectivas instâncias ${ }^{346}$.

Não se pode esquecer o teor da Súmula 19 do Supremo Tribunal Federal, que assim dispõe: "É inadmissível segunda punição de servidor público, baseada no mesmo processo em que se fundou a primeira".

Mônica Nicida Garcia afirma que a responsabilização pela prática de ato de improbidade administrativa ocupa um espaço próprio e não coincidente ou incluso em qualquer outra esfera:

Mantém-se, assim, a via própria e autônoma de repressão da improbidade administrativa e que já tinha lugar desde a Constituição de 1946 [...]. É preciso, pois, que fique absolutamente claro que o fato de haver outras esferas de responsabilização reprimindo a improbidade administrativa não impede a responsabilização pela via própria, que o legislador constituinte fez questão de estabelecer; ou melhor (porque já existente desde 1946), apenas manter ${ }^{347}$.

Um mesmo fato pode gerar quatro responsabilidades: civil, penal, administrativa e por atos de improbidade administrativa.

Para Mônica Nicida Garcia, a tese de que se trata de esfera distinta de responsabilização é reforçada pelo fato de que "não é possível enquadrar-se a responsabilização ditada pelo artigo $37, \S 4 .^{\circ}$, da Constituição Federal e pela Lei n. ${ }^{\circ}$ 8.429/92, quer na esfera criminal, quer na esfera administrativa, quer na esfera civil, ainda que haja, em certa medida, coincidência de sanções",348.

A esfera da responsabilidade civil visa somente a reparação do dano; a esfera administrativa tutela a boa administração, o bom andamento do serviço público, a disciplina interna do serviço público. A responsabilização pela prática de atos de improbidade não tem caráter penal, não se enquadrando em nenhuma das esferas acima citadas.

É importante ressaltar que a responsabilidade pela prática de atos de improbidade é uma esfera autônoma e independente, que se comunica com as demais esferas, sem com elas, entretanto, confundir-se.

Assim, entende-se que são quatro responsabilidades distintas que podem acumularse, pois são independentes: civil, penal, administrativa e por ato de improbidade.

\footnotetext{
${ }^{346}$ STF. MS 21.708-DF. Tribunal pleno. Rel. Min. Maurício Corrêa, Julgamento: 9 nov. 2000.

${ }^{347}$ GARCIA, Mônica Nicida. Responsabilidade do agente público. 2. ed. Belo Horizonte: Fórum, 2007. p. 234.

${ }^{348}$ GARCIA, 2007, p. 237-240.
} 


\subsection{REPERCUSSÃO DA SENTENÇA PENAL NA INSTÂNCIA DISCIPLINAR E CIVIL}

É importante observar a questão da comunicabilidade e da incomunicabilidade das instâncias penal, civil, administrativa e por ato de improbidade.

A independência das instâncias penal, civil, administrativa e de improbidade administrativa está consagrada na doutrina e na jurisprudência.

Ao lado disso, existe uma comunicação entre as diferentes esferas de responsabilidade, que, em alguns casos, incidem sobre o mesmo fato, ao qual, muitas vezes, cominam a mesma sanção, o que não lhes retira, entretanto, a autonomia e a independência e faz com que a responsabilização possa dar-se em uma, em algumas ou em todas as esferas.

Diante dessa realidade, o direito positivo contempla normas que buscam a compatibilização das instâncias, normas que se referem, fundamentalmente, à caracterização do ilícito, em cada uma das esferas, diante de um só fato.

As regras legais estabelecem, em geral, uma prevalência da esfera criminal sobre as demais, uma vez que a instrução probatória na ação penal é muito mais exigente. É preciso curvar-se ao que foi decidido, em termos de caracterização da conduta ilícita, em matéria criminal, ou seja, o que foi decidido na esfera criminal deve ser observado, de uma maneira geral, no âmbito civil, administrativo e também no âmbito da improbidade administrativa.

Serão adotados os ensinamentos de Edmir Netto de Araújo que estrutura com bastante organização as situações possíveis de comunicabilidade e de incomunicabilidade das instâncias para uma melhor compreensão do assunto ${ }^{349}$.

Edmir Netto de Araújo, com muita propriedade, afirma: "Se a falta é apenas administrativa, temos o que se costuma designar como ilícito administrativo puro, ontologicamente diverso do ilícito penal, e cujo julgamento se esgota no âmbito da Administração, em princípio" ${ }^{350}$.

Em seguida, Edmir Netto de Araújo alerta que em alguns casos, a falta administrativa é de tal gravidade que, além de ser um ilícito administrativo, é tipificada como infração penal. Está-se, então, diante do ilícito administrativo qualificado (ou penal). Nesse caso, haverá duplo julgamento: no âmbito da Administração e na esfera do Poder Judiciário $^{351}$.

\footnotetext{
${ }^{349}$ ARAÚJO, 2014, p. 1089-1098.

${ }^{350}$ ARAÚJO, 2014, p. 1089.

${ }^{351}$ ARAÚJO, 2014, p. 1090.
} 
No âmbito federal, o artigo 154, parágrafo único, da Lei n. ${ }^{o}$ 8.112/90 determina: "Na hipótese de o relatório da sindicância concluir que a infração está capitulada como ilícito penal, a autoridade competente encaminhará cópia dos autos ao Ministério Público, independentemente da imediata instauração do processo disciplinar".

Edmir Netto de Araújo identifica duas hipóteses que merecem ser estudadas:

1) Quando é imediatamente atribuído crime ao servidor (flagrante, provas documentais robustas, p. ex.), será imediatamente providenciado o inquérito policial, fornecendo-se, desde logo, a documentação à autoridade policial, por originais ou cópias, autenticadas ou não, e instaura-se o respectivo processo administrativo. Se o processo for decidido na esfera administrativa antes da esfera criminal, pode-se remeter cópias do processo ou de seus elementos essenciais, se for o caso, à autoridade policial ou judiciária, como peças informativas.

2) Quando, ao instaurar-se o processo administrativo, não houver a imputação imediata de ilícito penal, o mesmo terá seu curso normal, e, ao concluir-se pela prática de um delito, será remetido um "dossiê" com cópias do processo inteiro ou de seus elementos essenciais à autoridade policial, para o processamento criminal independente da apuração disciplinar $^{352}$.

A regra geral baseada no princípio da independência das instâncias prevê que cada processo em cada esfera ocorrerá de forma independente, pois a penalidade administrativa não está condicionada ao prévio pronunciamento do juízo criminal, podendo mesmo até ser demitido o servidor antes da decisão criminal. Em algumas situações, porém, é prudente aguardar a decisão judiciária. É o que ocorre, por exemplo, segundo Edmir Netto de Araújo, "quando os diplomas estatutários remetem à tipificação criminal a caracterização da falta a ser punida nas duas esferas, sem descrever, de forma autônoma, o comportamento ilícito"353.

Nos casos de crime contra a Administração Pública (artigo 132, I, da Lei n. ${ }^{\circ}$ 8.112/90), a independência das instâncias não é absoluta, pois não será admissível demitir o servidor por crime contra a Administração, sem que o Poder Judiciário decida se há ou não crime.

Sobre a matéria cível, recorremos mais uma vez aos ensinamentos de Edmir Netto de Araújo:

Por outro lado em matéria cível (no sentido de "não penal"), não se pode questionar a existência do fato ou sua autoria, quando essas matérias já foram decididas no crime (CC, art. 935), ou, ainda, o reconhecimento de excludentes de criminalidade (CPP, art. 65) já ocorrido na instância penal. Ao revés, permite-se a ação civil (qualquer ação) se, embora

${ }^{352}$ ARAÚJO, 2014, p. 1090, grifo do autor.

${ }^{353}$ ARAÚJO, 2014, p. 1091. 
absolutória a sentença penal, nela não houver sido categoricamente declarada a inexistência material do fato ${ }^{354}$.

Quando se trata de fato que é ilícito administrativo e ilícito penal, a dupla condenação confirma a decisão da esfera administrativa, adequando-se a pena disciplinar ao julgamento penal.

No caso de condenação judicial na esfera penal e de absolvição na esfera administrativa, a sentença penal condenatória faz coisa julgada no âmbito disciplinar e no cível, devendo, no caso, o julgamento administrativo ajustar-se ao que se decidiu no crime. A Administração vincula-se à decisão da esfera penal ${ }^{355}$.

A absolvição na esfera penal e na esfera administrativa confirma a decisão administrativa.

E se acontecer uma condenação administrativa e uma absolvição penal? É preciso examinar o fundamento da sentença penal absolutória, previsto no artigo 386 do Código de Processo Penal. Nesse ponto, verifica-se que não é absoluta a regra geral da independência das instâncias, pois, dependendo do fundamento da sentença absolutória, poderá ou não haver repercussão na esfera administrativa.

Edmir Netto de Araújo relaciona os casos em que haverá repercussão na decisão administrativa:

1) Absolvição fundada na inexistência do fato (art. 386, I, do CPP) ${ }^{356}$.

2) Não há prova da existência do fato (art. 386, II, do CPP) ${ }^{357}$.

3) Estar provado que o réu não concorreu para a infração penal ou não existir prova de que o réu concorreu para a infração penal (art. 386, IV e $\mathrm{V}$ do CPP) $)^{358}$.

4) Existência reconhecida de excludente de criminalidade (art. 23 do CP, estado de necessidade, legítima defesa, estrito cumprimento do dever legal ou exercício regular do direito $)^{359}$.

5) Eximentes de pena da lei criminal ${ }^{360}$.

${ }^{354}$ ARAÚJO, 2014, p. 1092, grifo do autor.

355 ARAÚJO, 2014, p. 1093.

${ }^{356}$ A repercussão dessa sentença, no processo administrativo, é integral (ARAÚJO, 2014, p. 1094).

${ }^{357}$ Repercute no âmbito administrativo (ARAÚJO, 2014, p. 1095).

${ }^{358}$ Repercute integralmente a sentença penal absolutória na decisão disciplinar (ARAÚJO, 2014, p. 1095).

359 "Embora existente o fato, e com autoria determinada, a conduta foi juridicizada, e tal sentença 'faz coisa julgada no cível' (art. 65 do CPP). Portanto, concluímos que na esfera administrativa o efeito é o mesmo, a conduta perde o caráter de ilicitude [...]" (ARAÚJO, 2014, p. 1095, grifos do autor)

${ }^{360}$ Repercutem relativamente na decisão administrativa, dependendo do exame de cada caso concreto. "O erro (arts. $20, \S 1 .^{\circ}$, e 21 do CP) poderá ser suficiente para eximir a pena no processo penal, se for de fato ou sobre a ilicitude do fato, mas não será impossível, nesse caso, restar um resíduo de conduta punível administrativamente. No caso de coação irresistível ou estrita obediência a ordem não manifestamente ilegal de superior hierárquico, a comunicabilidade ocorre, pois o art. 22 do próprio Código Penal só considera puníveis os autores da coação ou da ordem. A alienação mental (art. 26) poderá ser causa de comunicabilidade, mas também determinar outros procedimentos paralelos na Administração, como a readaptação ou a aposentadoria por invalidez. A embriaguez proveniente de caso fortuito, dependendo das 
6) Há, ainda, a hipótese de o servidor ser indiciado por "crime", sem que o respectivo diploma estatutário descreva autonomamente a conduta punível (art. 132, I, da Lei n. $\left.{ }^{\circ} 8.112 / 90\right)^{361}$.

Há casos em que a sentença penal absolutória não se comunica à decisão administrativa condenatória, que remanesce apesar de tal absolvição. Isso ocorre quando o fato não constitui infração penal (art. 386, III, do CPP) ${ }^{362}$.

Tampouco há repercussão na decisão administrativa quando a sentença absolutória, fundada em insuficiência, deficiência ou ineficiência de provas para a condenação (art. 386, V, do CPP) ou fundada dúvida da existência do crime (art. 386, VI, in fine) for insuficiente para que a justiça penal justifique uma condenação, mas for o bastante para fundamentar uma penalização no processo administrativo (art. 126 da Lei n. $\left.{ }^{\circ} 8.112\right)^{363}$.

As esferas de responsabilidade são distintas: a pena criminal atinge o indivíduo enquanto pessoa, integrante da sociedade; a penalidade administrativa atinge sua condição de agente público e a condenação civil, seu patrimônio. Apesar disso, dependendo da situação, poderá ou não haver comunicação entre as instâncias, havendo reflexos importantes nas diversas esferas de responsabilidade do agente público.

Em relação à responsabilização dos servidores por atos de improbidade administrativa observa-se que a maioria constitui crimes e/ou infrações administrativas e/ou atos que ensejam responsabilização civil, portanto, apesar de ser mais uma esfera de responsabilização independente, as penas previstas para os atos de improbidade, por sua

circunstâncias do fato, poderá determinar punição residual, apesar de eventual absolvição criminal. Mas a proveniente de força maior equipara-se à coação irresistível” (ARAÚJO, 2014, p. 1096, grifos do autor).

${ }^{361}$ Nesse caso, a instância fica em suspenso, aguardando o pronunciamento do Poder Judiciário. "Em certos casos, configura-se o procedimento irregular de natureza grave, punível com demissão simples; em outros, o processo poderá ser sobrestado". Tal "princípio não se aplica em relação a infrações que, embora constituam crime, estejam descritas autonomamente pelos diplomas estatutários, como condutas puníveis administrativamente (abandono de cargo, ofensas físicas em serviço etc.) [...]. A Administração não é obrigada a aguardar em nenhum caso [...] a sentença penal para decidir o processo administrativo, adequando sua decisão, se for o caso de repercussão. A absolvição criminal comunicável produz, na esfera administrativa, o efeito de, retroagindo, recompor todos os prejuízos e cancelar os efeitos da pena administrativa já aplicada, restabelecendo o status quo. Caso tenha sido aplicada penalidade expulsiva, a sentença penal autoriza a reintegração do funcionário, com todos os direitos e vantagens do cargo, como se não tivesse ocorrido a demissão, exonerando-se, sem direito a indenização (mas com direito a retorno ao cargo efetivo anterior, ou aproveitamento em outro cargo, ou colocação em disponibilidade) quem lhe ocupava o lugar, como determinam os Estatutos, em decorrência do art. 41, § 2. , da Constituição Federal" (ARAÚJO, 2014, p. 1096-1097, grifos do autor).

362 “A conduta do servidor, mesmo não sendo crime, poderá caracterizar a infringência a deveres e vedações funcionais, como faltas graves, afetando o funcionamento da máquina administrativa, e por isso mesmo ser passível de punição. Até mesmo a demissão pode ocorrer, se os fatos indicarem a ocorrência de procedimento irregular de natureza grave. Então, havendo previsão legal, mas em modelo não tão rígido quanto o criminal, o servidor poderá ser punido administrativamente, e a sentença penal absolutória que declare que o fato não é crime, nenhuma ingerência terá na esfera administrativa, exceto quando o servidor tenha sido indiciado por crime somente sem a descrição administrativa da conduta [...]"'(ARAÚJO, 2014, p. 1097, grifos do autor).

${ }^{363}$ ARAÚJO, 2014, p. 1097-1098. 
vez, também estão elencadas nas outras esferas de responsabilização: o ressarcimento na esfera civil; a perda de bens na esfera penal; a perda de função nas esferas administrativas e penal; a perda dos direitos políticos na esfera penal. Somente o pagamento de multa civil não parece ter previsão em qualquer outra esfera.

Reza o artigo 1.525 do Código Civil, cuja redação é quase idêntica ao do artigo 935 do novo Código Civil, que a responsabilidade civil é independente da criminal, não se podendo, porém, questionar mais sobre a existência do fato, ou sobre quem seja o seu autor, quando essas questões se acharem decididas no crime.

Eduardo García de Enterría e Tomás-Ramón Fernández afirmam que a inaplicabilidade do princípio do non bis in idem é, aliás, o que diferencia as sanções disciplinares das demais sanções administrativas ${ }^{364}$.

Não há restrição ao sancionamento múltiplo do agente, sendo ele, uma consequência da própria independência das esferas de responsabilidade do agente público $^{365}$.

Dessa forma, o artigo 125 da Lei n. ${ }^{\circ} 8.112 / 90$ é expresso no sentido de que as sanções civis, penais e administrativas poderão cumular-se, sendo independentes entre si.

Pode haver coincidência de sanções nas diferentes esferas de responsabilidade. Assim, o ressarcimento do dano pode dar-se nas esferas civil e de improbidade; a perda dos bens e valores acrescidos ilicitamente, nas esferas criminal e de improbidade; a perda da função pública, nas esferas criminal, administrativa e de improbidade; a suspensão dos direitos políticos, na criminal e de improbidade.

Como exemplo, cita-se o caso prático de um servidor que, acusado de corrupção passiva, tipificada no artigo 317 do Código Penal, exigia dos segurados o pagamento por diversos "serviços", os quais eram, na realidade, atos de ofício que tinha o dever de praticar. Tal conduta também configura ato de improbidade administrativa e infração disciplinar. À época dos fatos, o referido servidor exercia serviço temporário no INSS, no contrato havia referência à Lei n. ${ }^{\circ} 8.745 / 93$ - que, em seu artigo 11, determina a aplicação de diversos artigos da Lei $n .^{\circ} 8.112 / 90$, inclusive o artigo 142, § 2. ${ }^{\circ}$, da Lei n. $.^{\circ} 8.112 / 90$, aplicando-se os prazos prescricionais previstos na Lei penal quanto às infrações disciplinares concomitantemente definidas como crime. Instaurado o processo administrativo, o servidor temporário foi excluído, sob a alegação de que já não estava

\footnotetext{
${ }^{364}$ GARCÍA DE ENTERRÍA, Eduardo; FERNÁNDEZ, Tomás-Ramón. Curso de derecho administrativo. 4. ed. Madrid: Civitas, 1995, v. 2, p. 171.

${ }^{365}$ GARCIA, 2007, p. 319.
} 
mais trabalhando no INSS à época da investigação, prosseguindo o processo em relação aos demais réus. A situação foi questionada judicialmente, sendo determinado que o servidor continuasse no processo administrativo para a apuração de suas faltas disciplinares, mesmo já tendo terminado o seu contrato temporário.

Nesse caso, havia prática de atos de improbidade que também são enquadrados como crime de corrupção por parte dos réus, que deixaram de executar atos de ofício em troca de vantagens indevidas, em manifesto prejuízo ao interesse público. Suas atitudes foram desonestas e desleais, além de constituírem uma infração administrativa. Os servidores foram condenados nas esferas penal, administrativa e de improbidade administrativa, sofrendo a aplicação de sanções penais, administrativas e de improbidade administrativa.

Outra situação que merece ser examinada: um professor temporário foi penalizado pela apresentação de atestados médicos falsos, que lhe permitiram o recebimento por aulas não dadas. Após regular processo administrativo disciplinar, foi demitido. O professor, paralelamente ao feito disciplinar, foi processado pelo crime de falso. Nesse ínterim, o professor foi empossado como professor efetivo. Com efeito, uma vez condenado na esfera administrativa pela apresentação de atestados falsos, o servidor público temporário foi penalizado com a pena de demissão. Houve a confirmação da condenação pelo crime de falso. Em razão disso, o professor não poderia ter sido empossado em posterior concurso para professor efetivo. Os reflexos de tais condenações tornam sem efeito a posse.

As instâncias penal, civil, administrativa são independentes entre si e convivem de forma harmoniosa no ordenamento jurídico, sem se isolarem, pois, em algumas situações, em algumas hipóteses legais, como foi exposto, uma instância influi na outra, uma instância passa até mesmo a depender da outra para fins de procedibilidade.

Essa harmonia e essa perfeita integração entre as instâncias são de suma importância para a garantia da tão almejada segurança jurídica, visto que o objetivo de todas as instâncias é verificar a existência da prática de um ato ou fato jurídico ilícito por parte do servidor público ou pelo cidadão.

Assim, o servidor público temporário, quando da prática de uma infração disciplinar, deve responder em todas as instâncias (penal, civil, administrativa e por atos de improbidade administrativa) mediante um processo administrativo disciplinar, uma sindicância ou processo sumário, observado o devido processo legal, a ampla defesa e o contraditório. 


\subsection{A RESPONSABILIDADE DO SERVIDOR PÚBLICO TEMPORÁRIO}

O servidor público temporário não escapa à regra, sendo-lhe aplicado tudo o que foi estudado anteriormente quanto às responsabilidades civil, penal, administrativa e também por ato de improbidade administrativa, de acordo com a transitoriedade da contratação temporária.

Diante da realidade dos servidores públicos temporários, poder-se-ia até pensar em um "princípio de equiparação", ou seja, a responsabilidade dos servidores públicos temporários e a dos demais servidores públicos ("não temporários") são iguais, pois eles preenchem todos os requisitos: são servidores públicos e há responsabilidade, mas, como o vínculo temporário é reduzido, o processo administrativo disciplinar destinado a apurar a falta cometida também é reduzido.

Todavia, esse chamado regime equiparável necessita de adaptações em razão das especificações do vínculo especial a que se submete o servidor público temporário, e são justamente essas especificações que se pretende demonstrar.

Como se tenta introduzir no regime jurídico do servidor público temporário uma espécie de "princípio de equiparação", buscar-se-á, no capítulo sobre o processo administrativo disciplinar (Capítulos 4 e 5), construir um regime jurídico disciplinar a ser aplicado ao servidor público temporário, observando-se as suas peculiaridades, mas com base no processo de apuração do ilícito para os servidores públicos.

O ponto central deste trabalho reside na demonstração de que o servidor público temporário responde pelos atos ilícitos em todas as esferas: penal, civil, administrativa e por atos de improbidade. Não é porque está transitoriamente na função que será eximido de responsabilidade ou protegido pelo excepcional interesse público; pelo contrário, por ser um servidor público, está sujeito aos ônus e bônus do serviço público, ou seja, aos direitos e deveres, com as devidas adequações ao servidor temporário.

Assim, a responsabilidade do servidor público deverá ser apurada mediante um processo administrativo disciplinar especial (ou sindicância ou processo sumário), adaptado à realidade dos servidores públicos temporários, ou seja, por um instrumento processual pelo qual, respeitados o devido processo legal, o contraditório e a ampla defesa, chegar-se-á, se for o caso de responsabilização, à aplicação de uma medida sancionatória para aquele servidor temporário que cometeu um ilícito.

Atentos às peculiaridades desse servidor público temporário, buscar-se-á compatibilizar as suas características com o procedimento mais adequado para a apuração 
de suas faltas, garantindo a observância do devido processo legal, da ampla defesa e do contraditório durante todas as etapas do processo.

O presente trabalho abordará a responsabilidade do servidor público temporário pela prática de infrações disciplinares no âmbito administrativo, bem como o regime disciplinar aplicado ao temporário.

Sustenta-se que a regular apuração de eventuais infrações disciplinares cometidas por servidor temporário é medida imposta pelo interesse público, que reclama que o servidor faltoso, ainda que temporário, não seja pura e simplesmente "distratado", como se o desligamento se desse por "mera conveniência e oportunidade" da Administração. Sem a apuração, pode-se chegar, por exemplo, à absurda situação de um servidor temporário que cometeu ato de corrupção e foi novamente contratado pela Administração um ano após a extinção do vínculo.

A natureza precaríssima da contratação temporária exige apuração simplificada e célere de faltas disciplinares porventura praticadas em seu âmbito. A Lei n. ${ }^{\circ}$ 8.745/93 previu a utilização da sindicância com duração máxima de 30 (trinta) dias, que poderá, até mesmo, resultar na aplicação da pena de demissão. Não se concorda com a utilização da sindicância para aplicar uma penalidade de demissão ao servidor público temporário, mesmo em razão da natureza precária do vínculo. O mais adequado seria a previsão de um processo administrativo disciplinar adaptado, com prazos reduzidos, ou seja, um "miniprocesso administrativo disciplinar". Em razão de ausência de um rito próprio, buscar-se-á demonstrar como seria desenvolvido o processo administrativo disciplinar na apuração de faltas do servidor público temporário, atendidos os preceitos legais e constitucionais e particularidades do servidor público temporário.

Defende-se a aplicação aos servidores públicos temporários de um regime especial. Assim, também haveria um meio especial de apuração de infrações assemelhado ao processo administrativo disciplinar, com as peculiaridades adaptadas aos servidores públicos temporários, sempre observando o devido processo legal, o contraditório e a ampla defesa em todos os casos de aplicação de penalidade, mesmo uma simples advertência.

Poder-se-ia até mesmo utilizar a sindicância para a aplicação de uma advertência ou de uma suspensão por até 30 dias ao servidor público temporário (semelhante ao meio de apuração dos servidores públicos em geral), mas obedecendo-se ao devido processo legal, ao contraditório e à ampla defesa. 
Serão analisadas algumas situações nas quais o servidor temporário responde por seus atos ilícitos. Suponha-se, por exemplo, que um servidor temporário tenha praticado irregularidades em operações bancárias na conta corrente de determinada entidade pública, visto que foram feitos depósitos de ordens bancárias em contas indevidas, diversas daquelas em que deveriam ter sido realizados. Foram encontradas guias de depósito em nome do referido servidor temporário, bem como em nome de seus parentes.

As irregularidades administrativas devem ser objeto de apuração mediante processo administrativo disciplinar, encontrando-se entre as condutas legais a pena máxima de demissão se comprovada a lesão aos cofres públicos.

Deve-se ressaltar que a infração administrativa apurada no competente processo administrativo disciplinar, punível com demissão, tem repercussões que vão além do simples afastamento do servidor. No caso de ser impossível, na aplicação da penalidade de demissão, afastar o servidor que não mais possui vínculo com a administração pública, nada obsta a que consequências jurídicas acessórias (impossibilidade de retorno ao serviço público, por exemplo) sejam registradas.

Não se pode demitir quem já foi demitido ${ }^{366}$. Caso seja aplicada a penalidade de demissão a um servidor já demitido, deve-se, no despacho final, registrar a pena, sem aplicá-la, porquanto o servidor já terá sido demitido, registrando-se no prontuário do servidor a demissão para eventuais futuros direitos. Tal medida resguardará o interesse público, legitimará o devido assentamento da pena nos registros funcionais do servidor, permitirá a produção, quando for o caso, das providências que decorrem da aplicação da pena demissória.

Além disso, cabe a responsabilidade civil por ato irregular, por improbidade, e a representação ao Ministério Público para fins de apuração dos ilícitos penais.

Os atos cometidos no exemplo acima citado caracterizam atos de improbidade administrativa, previstos no artigo $37, \S 4 .^{\circ}$, da Constituição Federal e disciplinados pela Lei Federal n. ${ }^{\circ}$ 8.429/92. A conduta do servidor temporário pode ser enquadrada nas três espécies de atos de improbidade administrativa constantes na lei. Isso porque o servidor temporário beneficiou-se de verbas provenientes dos cofres públicos e destinadas a

\footnotetext{
${ }^{366}$ Em sentido contrário, Léo da Silva Alves ressalta a possibilidade jurídica de demitir quem já foi demitido e destaca a natureza do poder hierárquico da Administração, o efeito didático da pena e a eficiência do resultado, quanto à garantia de não reintegração, de penas acessórias e do registro em folhas funcionais (ALVES, Léo da Silva. Processo disciplinar em 50 questões. Brasília, DF: Brasília Jurídica, 2002, p.103104).
} 
terceiros, o que caracteriza enriquecimento ilícito, prejuízo ao erário e ofensa aos princípios da administração pública.

Dessa forma, o servidor temporário poderá ser acionado judicialmente por ato de improbidade, nos termos do artigo 17 da Lei n. ${ }^{\circ}$ 8.429/92, que atribui a competência processual para a propositura da ação ao Ministério Público, bem como à pessoa jurídica interessada, sem prejuízo da possibilidade de utilização das medidas cautelares de sequestro e indisponibilidade de bens.

O enquadramento da conduta do servidor temporário como ato de improbidade administrativa garante resultados e consequências jurídicas efetivas não só pelo fato de a lei adotar um conceito de agente público amplo e estender suas disposições inclusive a terceiros, como também pelas cominações estabelecidas nos incisos do artigo 12 da Lei de Improbidade, que vão desde o ressarcimento do dano, passando pela perda da função pública, até a suspensão de direitos políticos e a proibição de contratar com o Poder Público e receber benefícios ou incentivos fiscais.

No que tange ao ressarcimento do dano civil, considera-se o disposto no artigo 37, $\S 5 .^{\circ}$, da Constituição Federal.

Em relação ao ilícito penal, deve haver representação ao Ministério Público para fins de apuração dos ilícitos penais, pois a conduta do servidor temporário poderá ser enquadrada nos tipos penais contidos nos artigos do Código Penal n. ${ }^{\circ} 312$ (peculato) e n. ${ }^{\circ}$ 324 (exercício funcional ilegalmente antecipado ou prolongado).

Entende-se que deve ser instaurado processo administrativo disciplinar contra o servidor temporário, ainda que ele não mantenha mais vínculo com a Administração Pública, considerando-se que a irregularidade administrativa causadora de lesão aos cofres públicos foi praticada à época do vínculo existente.

Mesmo tratando-se de servidor temporário e sendo o vínculo mantido com a Administração considerado precário, o servidor temporário deverá responder pelos atos praticados na vigência do contrato, pois está sujeito aos princípios e regras do direito administrativo aplicável a todo e qualquer servidor.

Outra situação em que o servidor temporário responde civilmente, penalmente, administrativamente e por atos de improbidade: um servidor público temporário não prestou contas nem ressarciu o erário dos valores recebidos e supostamente não aplicados devidamente. Houve repasse ao servidor de determinado valor relativo às diárias que lhe permitiam a participação em um determinado curso de formação de professores, mas não houve prestação de contas. Cabe a instauração de processo administrativo disciplinar para 
apuração de faltas, independentemente da responsabilidade penal, civil e por improbidade administrativa.

Mais um caso que caracteriza a independência das instâncias: um servidor público temporário, ao ser preso em flagrante, requereu licença sem vencimentos pelo prazo de 30 (trinta) dias. Tal licença não é cabível no âmbito da contratação temporária. Se, em virtude de prisão em flagrante, o servidor não mais pode comparecer ao serviço, a providência que a Administração deve tomar é, em princípio, a rescisão unilateral do contrato temporário, além da apuração das demais responsabilidades.

É sabido que a contratação temporária só é permitida para o atendimento de necessidade temporária de excepcional interesse público (artigo 37, IX, da Constituição Federal) e, nessa medida, não se pode admitir que, estando o servidor impedido de comparecer ao serviço em razão de prisão em flagrante e, consequentemente, de dar atendimento à necessidade ensejadora da contratação, seja o contrato mantido em vigor em flagrante prejuízo ao interesse público.

Além disso, há necessidade de instauração de processo administrativo disciplinar, que viabilize a regular apuração da suposta falta funcional cometida pelo interessado, sendo oportunizada a ampla defesa e o contraditório que lhe são constitucionalmente assegurados (artigo 5. ${ }^{\circ}$, LV, da Constituição Federal). Sem esquecer que tal servidor responde criminalmente pelos seus atos.

Outro caso: um servidor temporário incorreu em inassiduidade habitual, tendo faltado ao serviço, sem causa justificada, por 60(sessenta) dias interpolados durante um ano. Tal servidor descumpriu os deveres elementares. Tal situação deve ser apurada em procedimento sumário em que lhe seja assegurada a ampla defesa e o contraditório. Da mesma forma, nos casos de descumprimento de obrigação imputável ao servidor temporário (como no caso de inassiduidade habitual), a extinção deve ser formalizada em procedimento sumário, no qual seja oportunizada ao servidor a ampla defesa e o contraditório, antes da extinção do vínculo.

Ao lado da responsabilidade do servidor público temporário, nos casos de contratação temporária irregular, poderia ser incluída na legislação brasileira, a exemplo da legislação portuguesa (artigo 92, n. ${ }^{\circ}$ 3, da Lei n. ${ }^{\circ}$ 59/2008, de 11 de setembro), a responsabilidade civil, disciplinar e financeira da pessoa (dirigente máximo dos órgãos ou serviços) que permitiu (celebrou) ou renovou a contratação (irregular). E ainda deve ser declarado nulo o contrato. 
Como se pode constatar, o servidor público temporário responde civilmente, penalmente, administrativamente e por atos de improbidade pela prática de um ilícito, como qualquer outro servidor público (princípio de equiparação). 


\section{REGIME DISCIPLINAR DO SERVIDOR PÚBLICO TEMPORÁRIO}

\subsection{CONSIDERAÇÕES INICIAIS SOBRE O REGIME DISCIPLINAR}

A Administração Pública visa atingir o interesse público, mas, para isso, precisa estruturar-se de forma adequada, devendo observar regras e princípios no desenvolvimento da atividade administrativa. Logo, todos os que integram a estrutura da Administração Pública devem respeitar e cumprir um conjunto de normas, sem as quais não será possível alcançar o tão almejado interesse público.

Paulo Veiga e Moura expressa muito bem a questão:

a disciplina constitui [...] o vector fundamental de toda a organização que envolva um factor humano e se predisponha a alcançar determinados objectivos, a qual não subsiste sem hierarquia e sem a imposição e o respeito de um conjunto de normas comportamentais, sejam elas do foro ético ou jurídico ${ }^{367}$.

O regime disciplinar é um conjunto de normas que enumeram os deveres jurídicos a que se submetem os servidores públicos, definem a tramitação procedimental para apurar a responsabilidade pelo descumprimento dos deveres, por intermédio da aplicação de sanções disciplinares tipificadas na lei.

Pressupõe esse regime disciplinar, explica Themístocles Brandão Cavalcanti, a obediência a um certo número de normas e deveres inerentes às funções que os servidores públicos exercem. Esses deveres correspondem aos direitos de que gozam, cujo reconhecimento está diretamente relacionado à maneira de cumprirem as suas obrigações funcionais $^{368}$.

Ensina Edmir Netto de Araújo:

Com efeito, ilícito administrativo é infração aos estatutos ou regulamentos que disciplinam o regime jurídico de pessoal da entidade à qual o agente está integrado ou prestando serviços. Nesse sentido amplo, estariam incluídas, no sentido lato da noção, as faltas administrativas ou disciplinares no âmbito das empresas, das entidades de classe (como Ordem dos Advogados do Brasil, Conselhos Regionais de Medicina, de Engenharia e Arquitetura etc.), e até mesmo de agremiações, associações ou clubes, além do sentido mais corriqueiro dos órgãos e entidades estatais. A própria CLT, nesse amplíssimo sentido, não deixaria de ser também um estatuto, dos trabalhadores em geral ${ }^{369}$.

\footnotetext{
${ }^{367}$ MOURA, Paulo Veiga e. Estatuto Disciplinar dos Trabalhadores da Administração Pública anotado. 2. ed. Coimbra: Coimbra Editora, 2011, p. 36.

${ }^{368}$ CAVALCANTI, 1946, p. 386.

${ }^{369}$ ARAÚJO, 2014, p. 978, grifos do autor.
} 
A obediência aos deveres e o respeito às proibições funcionais compreendem o regime disciplinar do serviço público ou, como diz Themístocles Brandão Cavalcanti, o "código especial de ética funcional" ${ }^{, 70}$, intimamente ligado à maneira e às condições do exercício funcional.

Odete Medauar enumera os principais aspectos do regime disciplinar ${ }^{371}$ : a) competência legal ${ }^{372}$; b) vinculação ao exercício do cargo, função ou emprego ${ }^{373}$; c) legalidade das infrações ${ }^{374}$; d) legalidade das sanções ${ }^{375}$; e) $\operatorname{prescritibilidade}^{376}$; f) motivação ${ }^{377}$.

Pode-se dizer que o regime jurídico disciplinar é o conjunto dos deveres, das normas disciplinares que devem ser cumpridas pelo servidor público. Deve haver a previsão legal das faltas (é o cometimento do ilícito administrativo) e das sanções disciplinares; devem existir procedimentos apuratórios das referidas faltas, com a garantia do direito de defesa na apuração das faltas disciplinares, além de um controle interno pela via recursal hierárquica - e externo - pelo exame da legalidade exercido pelo Poder Judiciário.

\footnotetext{
${ }^{370}$ CAVALCANTI, 1946, p. 386.

${ }^{371}$ MEDAUAR, 2011, p. 323-327.

372 "Os estatutos de servidores e as leis orgânicas das categorias funcionais atribuem competências para apurar infrações e para aplicar penas disciplinares; desse modo, o poder disciplinar não pode ser exercido sem estar legalmente atribuído" (MEDAUAR, 2011, p. 324).

373 “O vínculo ao exercício do cargo, função ou emprego norteia, por conseguinte, a caracterização das infrações passíveis de sanções disciplinares” (MEDAUAR, 2011, p. 324).

374 "Registrou-se uma nítida evolução no regime disciplinar, nas últimas décadas, para impedir que a 'atipicidade' seja invocada para camuflar conotações subjetivas no exercício do poder disciplinar. Um dos aspectos dessa evolução seria a crescente 'jurisdicionalização' dos processos disciplinares, que significa, em síntese, o reconhecimento, na esfera administrativa, de garantias das posições jurídicas dos indivíduos" (MEDAUAR, 2011, p. 325). Observa-se uma redução da discricionariedade, em virtude do estabelecimento de maiores garantias para os indiciados em processos disciplinares. "Mesmo que exista um resquício de discricionariedade na gradação das penas, a jurisprudência pátria e a estrangeira têm aplicado, nesse aspecto, o princípio da proporcionalidade, para que a gravidade da sanção corresponda à gravidade da conduta" (MEDAUAR, 2011, p. 325-326).

375 “O adágio nulla poena sine lege vigora em matéria de sanções disciplinares, daí ser vedada a aplicação de pena não arrolada em texto legal, não podendo ser 'inventada' modalidade punitiva” (MEDAUAR, 2011, p. 326).

376 “A possibilidade de aplicar sanções disciplinares não é perpétua; os estatutos fixam prazos prescritivos para a atuação disciplinar da Administração" (MEDAUAR, 2011, p. 326).

377 "Os atos referentes ao arquivamento de sindicância, à imposição de pena e à absolvição devem ser motivados, isto é, a autoridade competente deve explicitar as razões de fato e de direito que levaram à decisão, com base nos elementos dos autos" (MEDAUAR, 2011, p. 327).
} 


\subsection{REGIME JURÍDICO DISCIPLINAR DO SERVIDOR PÚBLICO TEMPORÁRIO COM BASE NA LEI FEDERAL N. ${ }^{\circ} 8.745 / 93$}

Neste tópico, será estudado o regime disciplinar do servidor público temporário, especificamente nos aspectos relacionados ao conhecimento de seus direitos, deveres, proibições. No capítulo seguinte, serão aprofundados os procedimentos apuratórios das faltas disciplinares cometidas, com a garantia do direito de defesa na apuração das faltas disciplinares, bem como as formas de controle interno e externo.

Para tanto, elegeu-se para análise a Lei Federal n. ${ }^{\circ}$ 8.745, de 9 de dezembro de 1993, que dispõe sobre a contratação por tempo determinado para atender a necessidade temporária de excepcional interesse público dos órgãos da Administração Federal direta, das autarquias e das fundações públicas.

\subsubsection{Direitos}

As vantagens de ordem pecuniária e os direitos em geral do servidor temporário no âmbito federal estão previstos na Lei n. ${ }^{\circ}$ 8.745/93 e, subsidiariamente, em algumas disposições da Lei n. ${ }^{\circ}$ 8.112/90, conforme artigo 11 da Lei n. ${ }^{\circ}$ 8.745/93.

$\mathrm{O}$ servidor temporário faz jus às mesmas vantagens pecuniárias concedidas ao servidor público efetivo. Por exemplo: remuneração, gratificações pela prestação de serviço extraordinário, gratificação natalina, diária, ajuda de custo, adicional de insalubridade, periculosidade ou atividades penosas, adicional noturno, adicional de férias e gratificação por encargo de curso ou concurso.

Quanto às vantagens de ordem geral, os servidores temporários têm direito a férias, afastamentos conciliáveis com a situação peculiar da temporariedade da função, petição e aposentadoria.

É importante ressaltar que o artigo $8 .^{\circ}$ da Lei n. ${ }^{\circ}$ 8.745/93 manda aplicar o disposto na Lei n. ${ }^{\circ}$ 8.647, de 13 de abril de 1993 (Regime Geral de Previdência Social) ${ }^{378}$, aos contratados por tempo determinado para atender a necessidade temporária de excepcional interesse público.

\footnotetext{
${ }^{378}$ A Lei n. ${ }^{\circ} 8.647 / 93$ dispõe sobre a vinculação do servidor público civil, ocupante de cargo em comissão sem vínculo efetivo com a Administração Pública Federal, ao Regime Geral de Previdência Social e dá outras providências.
} 


\subsubsection{Deveres}

A infringência pelo servidor temporário dos deveres e proibições a que está sujeito implica o ilícito administrativo, com a respectiva responsabilização funcional ou disciplinar. Pode também ocasionar o ilícito administrativo penal, em se tratando de responsabilidade penal, e/ou o ilícito civil, que enseja a responsabilidade civil, e mesmo a responsabilidade por atos de improbidade administrativa.

Com muita propriedade, Edmir Netto de Araújo destaca alguns deveres funcionais:

Os deveres funcionais representam normas de conduta (atitude ativa) do servidor, apontando para ele a forma ideal e regulamentar para o desempenho de suas atribuições públicas. Assim considerados, referemse mais propriamente à presença física do servidor na repartição, ao bom ambiente de trabalho que deve ser preservado para que o serviço seja produtivo, à própria pessoa do servidor inserido nesse ambiente (ou mesmo, em certos casos, fora dele), e às regras gerais sob as quais os serviços devem se desenvolver ${ }^{379}$.

Para Carlos Borges de Castro, os servidores públicos contratados pelo regime da Consolidação das Leis do Trabalho subordinam-se a deveres gerais dos funcionários, como assiduidade, pontualidade, discrição e à maior parte dos específicos, o mesmo ocorrendo em relação às proibições ${ }^{380}$.

Não são somente os servidores estatutários e empregados públicos que devem observar os deveres, os servidores públicos temporários também estão sujeitos a deveres que podem ser gerais, como assiduidade e pontualidade, ou específicos, como residência obrigatória, discrição e outros, pois os deveres do servidor não são, em princípio, diferentes dos deveres do trabalhador comum.

Adotando-se a classificação de Edmir Netto de Araújo, os deveres do servidor temporário podem ser assim divididos ${ }^{381}$ :

a) quanto à presença do servidor: ser assíduo e pontual ao serviço;

b) quanto ao ambiente de trabalho: tratar com urbanidade as pessoas;

c) quanto ao procedimento do servidor: manter conduta compatível com a moralidade administrativa; ser leal às instituições a que servir; representar contra ilegalidade, omissão ou abuso de poder;

d) quanto à prestação de serviços: observar as normas legais e regulamentares; cumprir as ordens superiores, exceto quando manifestamente ilegais; levar ao

\footnotetext{
${ }^{379}$ ARAÚJO, 2014, p. 419, grifo do autor.

${ }^{380}$ CASTRO, 1981, p. 77, p. 79 e p. 140.

${ }^{381}$ ARAÚJO, 2014, p. 418-431.
} 
conhecimento superior as irregularidades; guardar sigilo sobre assunto da repartição; zelar pela economia do material e pela conservação do patrimônio público; exercer com zelo e dedicação suas atribuições.

Tais deveres devem ser observados pelos servidores temporários sob pena de serem aplicadas sanções após sindicância ou processo administrativo disciplinar em que seja assegurada a ampla defesa e o contraditório.

\subsubsection{Proibições}

As proibições, as vedações, os deveres negativos são todas as ações que o servidor público temporário não pode fazer ou praticar, quando no exercício de sua função. Como diz Edmir Netto de Araújo, representam "um freio (atitude de abstenção, inércia) à conduta do agente em relação ao Poder Público em geral, em relação à própria repartição em que trabalha, e à forma de prestação de seus serviços à pessoa jurídica estatal”382.

Tal como os deveres, as proibições também importam em imputação de responsabilidade administrativa, com aplicação de penalidades que podem variar, sem que essas apenações impeçam a responsabilidade civil, penal e por ato de improbidade administrativa.

Edmir Netto de Araújo adota o seguinte critério para distinguir os deveres das proibições: é preciso determinar se a atitude é ativa ou passiva, pois "o cumprimento de um dever supõe, em tese, um comportamento ativo, ao passo que uma vedação corresponde, em regra, uma atitude passiva, de abstenção" ${ }^{\text {383 }}$. O referido autor classifica as proibições de forma a tornar clara e objetiva a sua compreensão ${ }^{384}$. Utilizando a classificação adotada por Edmir Netto de Araújo serão enumeradas as proibições referentes aos servidores temporários com base na lei federal (Lei n. $\left.{ }^{\circ} 8.745 / 93\right)$ :

a) Proibições relativas ao cargo ou função:

a.1) acumulação de cargos, empregos e funções (art. 118 a 120 da Lei n. ${ }^{\circ}$ 8.112/90)

- trata-se de vedação constitucional, prevista no artigo 37, XVI e XVII;

a.2) utilização indigna do cargo ou função (art. 117, IX, XII, da Lei n. ${ }^{\circ} 8.112 / 90$ );

a.3) exercício de atividades empresariais incompatíveis com a função pública (art.

117, X, XVIII, da Lei n. ${ }^{\circ}$ 8.112/90);

\footnotetext{
${ }^{382}$ ARAÚJO, 2014, p. 431, grifo do autor.

383 ARAÚJO, 2014, p. 432, grifos do autor. O referido autor ressalta que essa classificação nem sempre é exata.

${ }^{384}$ ARAÚJO, 2014, p. 433-449.
} 
a.4) patrocínio de interesses privados (art. 117, XI, da Lei n. ${ }^{\circ} 8.112 / 90$ );

a.5) aceitação de representação de Estado estrangeiro (art. 117, XIII, da Lei n. ${ }^{\circ}$ 8.112/90);

b) Proibições relativas ao procedimento do servidor no exercício de suas funções:

b.1) manifestações e atividades perturbadoras da atmosfera de trabalho (art. 117, V, da Lei n. $\left.{ }^{\circ} 8.112 / 90\right)$;

b.2) usura (art. 117, XIV, da Lei n. $\left.{ }^{\circ} 8.112 / 90\right)$;

b.3) ausência do serviço durante o expediente, sem prévia autorização do chefe imediato (art. 117, I, da Lei n. ${ }^{\circ} 8.112 / 90$ );

b.4) cometimento a pessoa estranha à repartição, fora dos casos previstos em lei, do desempenho de atribuição que seja de sua responsabilidade ou de seu subordinado (art. 117, VI, da Lei n. ${ }^{\circ} 8.112 / 90$ ).

c) Proibições relativas à própria prestação de serviços:

c.1) retirada e/ou utilização de documentos, materiais ou objetos da repartição (art.

117, II, XVI, da Lei n. ${ }^{\circ}$ 8.112/90);

c.2) desídia (art. 117, XV, da Lei n. ${ }^{\circ}$ 8.112/90);

c.3) recusa de inspeção médica (art. $130, \S 1 .^{\circ}$, da Lei n. ${ }^{\circ} 8.112 / 90$ );

c.4) recusa de dar fé a documentos públicos (art. 117, III, da Lei n. ${ }^{\circ}$ 8.112/90);

c.5) resistência injustificada ao andamento de documento e processo ou à execução de serviço (art. 117, IV, da Lei n. ${ }^{\circ} 8.112 / 90$ ).

Edmir Netto de Araújo ressalta:

A Consolidação das Leis do Trabalho não especifica proibições (ao menos, assim referidas) a empregados, mesmo públicos, da mesma forma que não disciplina deveres funcionais, preferindo arrolar, em seus artigos 482 (principalmente), 723, 725, 730 e 731 as justas causas para a rescisão unilateral e brusca do contrato de trabalho ${ }^{385}$.

Mais adiante, Edmir Netto de Araújo explica que isso ocorre porque a maior parte das infrações a esses deveres e proibições encontra como correspondente uma justa causa para a demissão ou a punição do empregado, no regime trabalhista ${ }^{386}$.

Considera-se que infringir uma proibição é mais grave do que infringir um dever, logo as sanções aplicadas para as proibições têm uma gravidade maior.

Da mesma forma, os servidores temporários estão sujeitos a proibições. Uma vez tendo praticado algo que não poderiam fazer, responderão por seus atos, sendo-lhes

\footnotetext{
${ }^{385}$ ARAÚJO, 2014, p. 433, grifos do autor.
}

${ }^{386}$ ARAÚJO, 2014, p. 433. 
aplicada uma sanção após a regular apuração de suas faltas, sempre com a garantia da ampla defesa e do contraditório. 


\section{PROCESSO ADMINISTRATIVO DISCIPLINAR}

\subsection{PODER DISCIPLINAR: OS PODERES DO ADMINISTRADOR}

A ideia de poder disciplinar envolve disciplina, apuração de irregularidades e aplicação de penalidades.

Em virtude da "necessidade de ordem, de equilíbrio nas relações humanas característico preceito ético-jurídico -, surge a exigência da disciplina e o poder que a traduz"387.

O poder disciplinar tende a aplicar uma forma determinada de sanção, o que levou estudiosos a identificá-lo com o direito penal. Somente autores muitos antigos admitem a confusão do direito disciplinar com o direito penal.

Cino Vitta divide as diferentes doutrinas sobre o direito disciplinar dentro de um quadro que tem por base as relações do direito e das transgressões disciplinares com outras modalidades de sanções civis e penais, conforme a seguinte classificação:

a) Grupo de doutrinas que estabelecem semelhança entre as sanções disciplinares e civis. Defensores: Pfeiffer, Laband, Rehm, Pacinotti.

b) Grupo de doutrinas que admitem analogia entre as sanções disciplinares e as penais quanto aos seus fins. Defensores: Gonner, Heffter, Dolhmann, Binding, Giriodi, Manzini, Otto Mayer.

c) Aqueles que reconhecem a identidade dos meios usados nas diversas espécies de sanções, embora diferentes as normas aplicadas. Defensores: von Liszt, Schulze, Loning, Jellinek, Nezard, Raneletti, Santi Romano, Ugo Forti.

d) Grupo de doutrinas que estabelecem perfeita afinidade entre o direito disciplinar e o direito penal. Defensores: Mittermayer, Mayer, von Bar, Seydel, Zorn, Hauriou, Jèze, Vaccheli, Presutti, Cammeo ${ }^{388}$.

Atualmente, admite-se o caráter puramente administrativo do poder disciplinar. $\mathrm{O}$ poder disciplinar subsiste independentemente do poder repressivo penal ${ }^{389}$.

Odete Medauar afirma que não se deve confundir o poder disciplinar com o poder penal do Estado:

[O poder penal do Estado] é exercido pelo Poder Judiciário, regido pelo processo penal; visa à repressão de condutas qualificadas, na legislação penal, como crimes e contravenções; portanto, tem a finalidade de

\footnotetext{
${ }^{387}$ BARROS JÚNIOR, Carlos S. de. Do poder disciplinar na administração pública. São Paulo: Revista dos Tribunais, 1972, p. 6.

388 VITTA, Cino. Il potere disciplinare sugli impiegati pubblici. Milano: Società editrice libraria, 1913 apud CAVALCANTI, Themístocles Brandão. Direito e processo disciplinar. 2. ed. Rio de Janeiro: Fundação Getúlio Vargas, 1966, p. 88-89.

${ }^{389}$ CAVALCANTI, 1966, p. 103.
} 
preservar, de modo precípuo, a ordem e a convivência na sociedade como um todo. O poder disciplinar, por sua vez, é atividade administrativa, regida pelo direito administrativo, segundo normas do processo administrativo; visa à punição de condutas qualificadas em estatutos ou leis administrativas como infrações ou ilícitos; tem a finalidade de preservar, de modo imediato, a ordem interna do serviço, para que as atividades do órgão possam ser realizadas sem perturbação, dentro da legalidade e da lisura. A diferença entre as duas atuações possibilita sua concomitância ante a mesma conduta do servidor, ensejando a imposição conjunta de sanção administrativa e de sanção penal, sem que possa ser invocado o bis in idem ${ }^{390}$.

Mais uma diferença que merece ser ressaltada é a que existe entre poder disciplinar e poder hierárquico. Edmir Netto de Araújo alerta que não se pode confundir poder disciplinar e poder hierárquico. Em um primeiro momento, o poder disciplinar poderia ser considerado como incluído na noção de poder hierárquico, o que parece confirmar-se com a exigência, por exemplo, de processamento disciplinar por funcionário de igual ou superior hierarquia que o indiciado. Mas o sentido lato do poder disciplinar, englobando pessoas que não possuem relação funcional com a Administração, justifica que tal poder mereça consideração à parte ${ }^{391}$.

Para Odete Medauar, o poder disciplinar liga-se ao poder hierárquico, embora um não se reduza ao outro:

O poder hierárquico é mais amplo que o poder disciplinar. Este, por sua vez, pode não se exercer totalmente na linha hierárquica direta entre servidores ou entre órgãos. Por exemplo: em administrações em que a apuração de faltas funcionais se realiza de modo centralizado, num órgão específico para essa atividade, inexiste linha hierárquica direta entre tal órgão e o servidor cuja conduta se apura; no caso, a hierarquia direta pode ocorrer no momento da decisão final do processo disciplinar, ou seja, no ato de absolver ou punir o servidor. Um "sentido" hierárquico existe no preceito muito difundido na Administração brasileira, segundo o qual somente servidores de igual ou superior grau hierárquico podem apurar faltas de outro e aplicar-lhe pena ${ }^{392}$.

Edmir Netto de Araújo sustenta que o poder disciplinar envolve dois aspectos entre si ligados ${ }^{393}$ : determinar providências apuratórias das irregularidades, se competente for o agente, ou providenciar a comunicação à autoridade competente para fazê-lo, sob pena de responsabilidade, até mesmo criminal (condescendência criminosa, artigo 320 do Código Penal $)^{394}$; aplicar penalidades a agentes públicos e contratados.

\footnotetext{
${ }^{390}$ MEDAUAR, 2011, p. 125.

${ }^{391}$ ARAÚJO, 2014, p. 483.

${ }^{392}$ MEDAUAR, 2011, p. 125.

${ }^{393}$ ARAÚJO, 2014, p. 483.

${ }^{394}$ Esse poder-dever engloba as garantias constitucionais do devido processo legal, da ampla defesa e do contraditório, para penalizar alguém em qualquer sede, administrativa ou judiciária (art. 5. ․, LIV e LV, CF).
} 
Tal poder apresenta limites: as garantias constitucionais do devido processo legal, da ampla defesa e do contraditório; a competência para aplicar a respectiva penalidade; a legalidade em sua aplicação (não podem ser aplicadas penalidades inexistentes na lei ou não correspondentes à falta praticada).

É importante analisar algumas visões sobre o poder disciplinar.

Edmir Netto de Araújo explica o que é poder disciplinar de forma clara e precisa:

Os agentes públicos se sujeitam ao regime jurídico da pessoa política (e seus órgãos) ou entidade a que pertencem, o que, no plano interno, significa também a sujeição às respectivas normas disciplinares. Estas atribuem à respectiva Administração (e, portanto, às pessoas de seus administradores, enquanto nessa condição) o poder-dever (sob pena de responsabilidade) de apurar os ilícitos administrativos praticados pelos servidores e aplicar as respectivas penalidades, na esfera disciplinar. É o Poder Disciplinar que, entretanto, não se restringe às relações funcionais, mas também se estende às relações contratuais travadas pela Administração com particulares: sua abrangência envolve também a apuração das infrações do contratado na execução do respectivo contrato administrativo, e a aplicação das penalidades previstas na lei, observando o princípio constitucional da ampla defesa ${ }^{395}$.

O referido autor chama a atenção para o fato de que não se inclui nesse poder, no entanto, a aplicação de medidas punitivas a particulares que não tenham relação contratual ou funcional com o Estado, as quais são objeto do estudo do poder de polícia.

Odete Medauar define o poder disciplinar da seguinte maneira:

O poder disciplinar é atribuído a autoridades administrativas com o objetivo de apurar e punir faltas funcionais, ou seja, condutas contrárias à realização normal das atividades do órgão e irregularidades de diversos tipos. Incide principalmente sobre servidores; mas pode abranger também a conduta de outras pessoas, como, por exemplo, a de alunos de escolas públicas, que, num determinado período, vinculam-se estreitamente às atividades de um órgão ${ }^{396}$.

Para Hely Lopes Meirelles, poder disciplinar é:

A faculdade de punir internamente as infrações funcionais dos servidores e demais pessoas sujeitas à disciplina dos órgãos e serviços da Administração. É uma supremacia especial que o Estado exerce sobre todos aqueles que se vinculam à Administração por relações de qualquer natureza, subordinando-se às normas de funcionamento do serviço ou do estabelecimento que passam a integrar definitiva ou transitoriamente ${ }^{397}$.

No conceito de Hely Lopes Meirelles, o poder disciplinar é tido como uma faculdade. Não se concorda com essa afirmação, pois entende-se que o poder disciplinar é

\footnotetext{
${ }^{395}$ ARAÚJO, 2014, p. 483, grifos do autor.

${ }^{396}$ MEDAUAR, 2011, p. 124.

${ }^{397}$ MEIRELLES, 2012, p. 130.
} 
um poder-dever ou dever-poder, a autoridade que tomar conhecimento da prática de ilícitos deve apurá-los, sob pena de caracterização de responsabilidade.

Observam-se nos conceitos trazidos à colação alguns pontos em comum: os agentes públicos estão sujeitos ao regime jurídico da pessoa política ou entidade a que pertencem; o poder disciplinar é atribuído a autoridades administrativas, objetivando a apuração e a punição de faltas funcionais; o poder disciplinar não se restringe às relações funcionais, mas também se estende às relações contratuais travadas pela Administração com particulares, definitiva ou transitoriamente, ou seja, todos aqueles que se vinculam à Administração por relações de qualquer natureza, subordinam-se às normas de funcionamento do serviço.

Por intermédio do poder disciplinar, a Administração Pública pode exercer uma espécie de controle sobre o desempenho e a conduta de seus subordinados, responsabilizando-os pelas faltas cometidas.

Como bem explica Marcello Caetano: "O Poder disciplinar tem sua origem e razão de ser no interesse e na necessidade de aperfeiçoamento progressivo do serviço público"398.

$\mathrm{Na}$ visão de Odete Medauar, quando se fala em poder disciplinar, soa estranho associá-lo atualmente à discricionariedade:

Concepção clássica do direito administrativo associa poder disciplinar a discricionariedade. A respeito da discricionariedade em geral, há hoje uma tendência universal de circunscrevê-la e direcioná-la. Não mais é viável invocar poderes livres ou zonas livres a título de discricionariedade. Um rol de princípios e exigências que integram o direito administrativo contemporâneo denotam o direcionamento da discricionariedade. No tocante ao poder disciplinar, soa estranho atualmente associá-lo à discricionariedade: de início, em virtude dos parâmetros que norteiam o poder discricionário em geral; em segundo lugar, porque o poder disciplinar há muito vem se exercendo sob moldes processuais, justamente para impedir arbítrios e subjetivismos. Os paradigmas processuais mostram-se incompatíveis com atuações livres e desvinculadas de preceitos legais, tanto que sob tais moldes se exerce a função jurisdicional ${ }^{399}$.

Como reflexo disso, Odete Medauar destaca dois pontos: a necessidade da garantia do contraditório e da ampla defesa nos processos administrativos e aos acusados em geral

${ }^{398}$ CAETANO, Marcello. Do poder disciplinar no direito administrativo português. Coimbra: Imprensa da Universidade, 1932, p. 25.

${ }^{399}$ MEDAUAR, 2011, p. 126. 
(inciso LV do artigo $5 .^{\circ}$ da CF) e a repercussão em toda a elaboração jurisprudencial pátria, de forma a haver uma restrição a margens livres que pudessem levar ao arbítrio ${ }^{400}$.

Edmir Netto de Araújo adverte que, embora haja certa discricionariedade na gradação da penalidade em relação à infração ${ }^{401}$, "não tem o agente, ante a confirmação do ilícito, liberdade de escolha entre processar ou não processar, punir ou não punir, comunicar ou deixar de comunicar a infração" ${ }^{402}$.

Observa-se que o direito disciplinar ganhou importância principalmente com o advento da Constituição Federal de 1988, dando ênfase ao devido processo legal, à ampla defesa e ao contraditório. $\mathrm{O}$ que se pode dizer é que houve uma nova roupagem do direito disciplinar, principalmente com as novas garantias constitucionais, situação muito diferente do que ocorria anteriormente.

$\mathrm{Na}$ verdade, o poder disciplinar é um dever da autoridade, conforme o artigo 143 do Estatuto dos Servidores Civis Federais (Lei n. ${ }^{\circ}$ 8.112/90), que dispõe o seguinte: “A autoridade que tiver ciência de irregularidade no serviço público é obrigada a promover a sua apuração imediata, mediante sindicância ou processo administrativo disciplinar, assegurada ao acusado ampla defesa". Preceito semelhante encontra-se nos demais estatutos de servidores.

\subsection{APURAÇÃO DO ILÍCITO PELA ADMINISTRAÇÃO COM BASE NA LEI FEDERAL N. ${ }^{\circ} 8.112 / 90$}

Primeiramente será analisado o rito processual adotado pela Lei Federal n. ${ }^{\circ}$ 8.112/90 para a apuração do ilícito do servidor público federal, que servirá de base, de guia, uma forma de orientação para o processo de apuração de faltas do servidor público temporário que se pretende apresentar.

Em razão da inexistência de um rito processual previsto na Lei n. ${ }^{\circ}$ 8.745/93 para a apuração das faltas do servidor público temporário, partindo dos procedimentos gerais aplicados ao servidor público e considerando as particularidades do servidor público temporário, buscar-se-á compatibilizar, naquilo que for possível, o rito processual adotado para os servidores em geral. Para isso, é preciso conhecer todas as formas de apuração das infrações adotadas pela Lei n. ${ }^{\circ}$ 8.112/90 para poder fazer uma comparação segura.

\footnotetext{
${ }^{400}$ MEDAUAR, 2011, p. 126.

${ }^{401} \mathrm{O}$ autor refere-se a atenuantes ou agravantes, e também na caracterização das faltas, exemplifica com as faltas de procedimento irregular de natureza grave, insubordinação grave.

${ }^{402}$ ARAÚJO, 2014, p. 483.
} 
A questão da jurisdicionalização do processo administrativo não é recente. Conforme os ensinamentos de Léon Duguit, em todos os países, e particularmente na França, há uma tendência acentuada para aproximar-se a repressão disciplinar da repressão penal. A tendência da repressão disciplinar para jurisdicionalizar-se aparece sob diversos aspectos.

Esta transformação se explica naturalmente pela necessidade, que se faz sentir mais premente a cada dia, de se conceder a todos os indivíduos, funcionários ou simples particulares, uma proteção tão completa quanto possível contra o arbítrio. Esta transformação se liga também à idéia muito justa de que, se os agentes se sentem melhor amparados, contra o arbítrio dos Chefes de serviços, eles agirão mais utilmente, com mais zelo e atividade, nas tarefas que lhes são cometidas. [...] Estou convencido de que chegará o momento em que, para a repressão duma falta de serviço de qualquer funcionário, haverá uma verdadeira jurisdição diante da qual se desenvolverá um debate contraditório, um momento em que haverá uma definição legal e uma enumeração limitativa dos fatos capazes de constituir uma falta de serviço e uma enumeração legal e limitativa de penalidades que possam ser pronunciadas para se reprimir essa falta ${ }^{403}$.

O presente estudo terá como base o estatuto federal - a Lei n. ${ }^{\circ} 8 \cdot 112 / 90$. Não se pode esquecer que o procedimento e as denominações na lei de alguns estados e municípios podem ser diferentes do estatuto federal, mas no geral a essência é a mesma.

A autoridade, ao tomar conhecimento de irregularidade no serviço público, tem o dever de determinar a imediata apuração do fato censurável, a fim de restabelecer a regularidade e a continuidade do serviço público. É oportuno dizer que esse juízo preliminar - que determina a instauração do processo - deve estar fundado em motivo razoável, ou seja, deve haver um princípio de prova.

A autoridade deverá fazer uma análise prévia da denúncia, levantando todos os elementos acerca da suposta irregularidade, ponderando a necessidade e a utilidade de determinar a instauração da sede disciplinar (e da potencial responsabilização do servidor), isto é, uma espécie de juízo (ou exame) de admissibilidade, um juízo preliminar.

A autoridade que tiver ciência de irregularidade no serviço público deve promover a sua apuração imediata, mediante sindicância ou processo administrativo disciplinar, assegurada ao acusado ampla defesa (artigo 143 da Lei n. ${ }^{\circ}$ 8.112/90). O descumprimento desse dever acarretará responsabilidade civil, penal e administrativa.

É bom ressaltar que a autoridade deve obediência igualmente ao parágrafo único do artigo 144, da Lei n. ${ }^{\circ} 8.112 / 90$, que recomenda o arquivamento da denúncia quando o fato narrado não configurar evidente infração disciplinar ou ilícito penal.

${ }^{403}$ DUGUIT, Léon. Traité de droit constitutionnel. 3 éd. Paris: E. de Boccard, 1930, v. 3, p. 278-279. 
Assim, se a denúncia traz bons indícios apenas do cometimento do fato, sem indicar a autoria, poder-se-ia, a princípio, cogitar a instauração de sindicância contraditória. De outro lado, se a notícia traz bons indícios tanto do fato quanto da autoria, haveria justificativa para propor a instauração de processo administrativo disciplinar.

O importante é que deve haver indícios da suposta irregularidade. Nessa fase, para que se instaure o meio apuratório, basta a existência de plausibilidade da ocorrência do fato e de sua autoria. Tal cautela justifica-se para evitar instaurações inócuas.

O objetivo da punição é o aprimoramento e a eficiência dos serviços administrativos. A finalidade da ação processual disciplinar é punir para melhorar não só a atividade administrativa, como também a própria pessoa do servidor, para que passe a exercer o seu trabalho sempre de forma eficiente e honesta; ou, se for o caso, excluí-lo do quadro de pessoal, quando a gravidade da falta por ele praticada demonstrar ser inviável sua permanência no serviço público oficial ${ }^{404}$.

A Lei n. ${ }^{\circ} 8.112$, de 12 de novembro de 1990, prevê três espécies de processos administrativos: o processo administrativo disciplinar stricto sensu (ou de rito ordinário, artigo 146), a sindicância disciplinar autônoma (artigo 145, II) e o processo disciplinar sumário (artigos 133 e 140).

O que determina a escolha entre processo administrativo disciplinar e sindicância são essencialmente dois fatores: a existência ou não de indicadores de autoria e a gravidade da infração denunciada. Se na denúncia constem indícios apenas sobre o fato, o ideal seria a instauração de uma sindicância. Se, por outro lado, na representação há indícios de autoria e de materialidade, caberia a instauração do processo administrativo disciplinar, se a infração for de natureza grave; caso contrário, se a infração for leve, pode-se instaurar a sindicância.

Já o procedimento sumário é aplicado nos seguintes casos: apuração de acumulação ilegal de cargos, de abandono de cargo e de inassiduidade habitual, sendo em todos os casos cabível a pena de demissão.

\subsubsection{Processo administrativo disciplinar}

Do cometimento do ato ilícito, decorre a responsabilização do servidor, e o processo administrativo é o instrumento legal necessário para responsabilizar

${ }^{404}$ OCTAVIANO, Ernomar; GONZALES, Átila José. Sindicância e processo administrativo. 11. ed. São Paulo: Livraria e Editora Universitária de Direito, 2009, p. 133. 
administrativamente o servidor infrator por ato ou omissão associada diretamente ao exercício das atribuições do seu cargo ou, indiretamente, a pretexto de exercê-las.

Para José Cretella Júnior, processo administrativo é:

O conjunto de iniciativas da Administração, que envolvem o servidor público, possibilitando-lhe, porém, a mais ampla defesa, antes da edição do ato final da autoridade maior, decisão que o absolve ou o condena, depois de analisar-lhe a conduta que teria configurado, por ação ou omissão, ilícito administrativo, funcional, disciplinar ou penal ${ }^{405}$.

José dos Santos Carvalho Filho, ao tratar do processo administrativo disciplinar, afirma: "Processo administrativo-disciplinar é o instrumento formal por intermédio do qual a Administração apura a existência de infrações praticadas por seus servidores e, se for o caso, aplica as sanções adequadas" ${ }^{\sharp 06}$.

Assim, o processo administrativo disciplinar é a sucessão formal de atos realizados pela Administração Pública, com o objetivo de apurar os fatos relacionados com a disciplina de seus servidores. O processo administrativo disciplinar visa esclarecer a verdade dos fatos constantes da representação ou denúncia.

Antônio Carlos Alencar Carvalho, sobre o processo administrativo disciplinar, sintetiza: "É o instrumento destinado à comprovação e punição de irregularidades verificadas na atividade funcional dos agentes da Administração Pública, com vistas a promover a aplicação do estatuto de disciplina aos fatos constitutivos de infrações disciplinares" $" 407$.

O processo administrativo disciplinar é obrigatório para a aplicação de qualquer tipo de penalidade administrativa e é uma espécie de instrumento de prova de inocência do servidor. É uma verdadeira prerrogativa, o servidor somente pode ser penalizado após submeter-se a rito com garantia de ampla defesa e de contraditório, respeitado o devido processo legal.

$\mathrm{Na}$ administração pública federal, o processo administrativo disciplinar tem como base legal a Lei n. ${ }^{\circ}$ 8.112, de 11 de dezembro de 1990, em seus Títulos IV (do Regime, artigos 116 a 142) e V (do Processo, artigos 143 a 182).

As fontes do processo administrativo disciplinar são a Constituição Federal, a Lei n. ${ }^{\circ} 8.112$, de 11 de dezembro de 1990 e, subsidiariamente, a Lei n. ${ }^{\circ} 9.784$, de 29 de janeiro

\footnotetext{
${ }^{405}$ CRETELLA JÚNIOR, José. Prática do processo administrativo. 7. ed. São Paulo: Revista dos Tribunais, 2009 , p. 45.

${ }^{406}$ CARVALHO FILHO, 2012a, p. 975.

${ }^{407}$ CARVALHO, Antônio Carlos Alencar. Manual de processo administrativo disciplinar e sindicância: à luz da jurisprudência dos Tribunais e da casuística da Administração Pública. 3. ed. Belo Horizonte: Fórum, 2012, p. 613.
} 
de 1999 (que regula o processo administrativo no âmbito da administração pública federal); na falta de dispositivos aplicáveis nas leis anteriores, recorre-se ao Código de Processo Penal e ao Código de Processo Civil.

Impõe-se a instauração de processo administrativo disciplinar sempre que o ilícito praticado pelo servidor ensejar a aplicação de penalidade de suspensão por mais de 30 dias, de demissão, de cassação de aposentadoria ou disponibilidade, ou de destituição de cargo em comissão (artigo 146 da Lei n. ${ }^{\circ} 8.112 / 90$ ).

É importante chamar a atenção para o fato de que o processo administrativo disciplinar pode resultar na aplicação de penalidade de advertência ou de suspenção de até trinta dias e que a autoridade competente pode instaurar de imediato o processo administrativo disciplinar, não sendo a sindicância pré-requisito.

Como o processo administrativo disciplinar tem por objeto a apuração de faltas graves, requer um rito mais formal. Com efeito, a Lei n. ${ }^{\circ}$ 8.112/90 disciplinou, no artigo 151, as três fases em que se desenvolve o processo disciplinar: instauração, com a publicação do ato que constituir a comissão; inquérito administrativo, que compreende instrução, defesa e relatório; julgamento.

Na primeira fase - instauração -, a autoridade emite um juízo de admissibilidade quando decide pela instauração ou pelo arquivamento da imputação - artigos 143, 144 e parágrafo único da Lei n. ${ }^{\circ}$ 8.112/90. Na segunda fase do inquérito administrativo, desenvolve-se o trabalho de apuração, que se desdobra em instrução, defesa e relatório, disciplinados nos artigos 153 até 166 da Lei n. ${ }^{\circ}$ 8.112/90. A última fase é a decisória, em que a autoridade competente fará o julgamento do processo administrativo disciplinar (artigos 167 até 173 da Lei n. ${ }^{\circ}$ 8.112/90). Portanto, o processo disciplinar compreende uma série de atos que se iniciam com a portaria instauradora e se encerram com o julgamento da autoridade administrativa competente.

A fase da instauração é de suma importância para que se prepare a legítima desenvoltura da seriação de atos processuais que comporão a substância do apuramento dos fatos.

Segundo o professor Edmir Netto de Araújo, os trabalhos de instauração do processo administrativo envolvem principalmente matérias relacionadas "à competência, formalização dos atos instrutórios, designação da comissão processante e fixação dos prazos, de acordo com a lei" ${ }^{408}$.

${ }^{408}$ ARAÚJO, 2014, p. 991. 
José Armando da Costa destaca a necessidade de conectivos processuais de iniciação (princípios de prova) como forma de evitar que o servidor público venha a sofrer os incômodos e os aborrecimentos oriundos de um processo disciplinar precipitadamente instaurado.

"Tal precaução, além de velar pelo princípio constitucional da dignidade humana, proporciona resguardo à função pública exercida pelo acusado. Cuidado esse que se reveste, por fim, em benefício da normalidade e regularidade do serviço público. Escopo inarredável a que deve preordenar-se toda a repressão disciplinar" ${ }^{209}$.

Além disso, com tal cuidado, resguarda-se a dignidade do cargo ocupado pelo acusado. Daí a importância de tomar todos os cuidados preparatórios relacionados com a instauração do processo disciplinar, sob pena de ensejar nulidades insanáveis.

A instauração do processo administrativo disciplinar somente se legitima quando houver um mínimo de fatos indicativos da possibilidade de vir a ser futuramente punido o servidor que, sendo o possível autor da infração veiculada, esteja sujeito ao poder disciplinar de quem tenha a competência para iniciar o respectivo procedimento.

Quanto à competência, Edmir Netto de Araújo deixa claro: "competência para instaurar ou determinar a instauração não significa necessariamente competência para decidir o processo administrativo. Tal competência pode estar com outra autoridade hierarquicamente superior, ou mesmo em órgãos especiais, como colegiados"410.

Em relação à competência para instaurar, deve-se observar o regramento interno do órgão, de forma que o ato seja realizado pela autoridade expressamente competente para instaurar o processo administrativo disciplinar.

Com muita propriedade, Edmir Netto de Araújo sintetiza as providências administrativas de instauração:

compreendem, basicamente, a designação de Comissão processante, se houver (Município e União) e não for permanente, e a fixação, de acordo com a lei, dos prazos de início e conclusão do processo administrativo. Se, além de ilícito administrativo, a conduta a ser apurada configurar também infração penal, deve a Comissão ou a autoridade competente comunicar os fatos à autoridade policial, fornecendo os elementos de prova de que dispuser, comunicação essa que pode ser feita também oportunamente, durante o desenvolver das apurações ${ }^{411}$.

${ }^{409}$ COSTA, 2010, p. 220.

${ }^{410}$ ARAÚJO, 2014, p. 991.

${ }^{411}$ ARAÚJO, 2014, p. 992, grifos do autor. 
A escolha dos membros da comissão deve ser cuidadosa, de forma a se ter uma qualificada comissão, cujos membros preencham determinados pré-requisitos. Tal designação deverá recair em servidores idôneos, independentes, insuspeitos e competentes.

José Armando da Costa classifica os requisitos que devem ser atendidos pelos membros da comissão em funcionais e subjetivos. Os requisitos subjetivos estão relacionados ao fato de que os membros da comissão devem ter indiscutível idoneidade moral e comprovada capacitação intelectual. No que tange aos requisitos funcionais, são impostos de forma obrigatória pelas normas processuais pertinentes, devendo ser respeitados, sob pena de nulidade do processo $^{412}$. Destacam-se:

a) ter estabilidade no serviço público (artigo 149 da Lei n. ${ }^{\circ}$ 8.112/90);

b) ser insuspeito e não impedido;

c) não ocupar cargo de confiança;

d) ser funcionário da mesma repartição - em princípio, os membros da comissão devem ser escolhidos entre os servidores da mesma repartição, exceto nos casos de absoluta e comprovada necessidade, abrindo-se exceção nas hipóteses do $§ 3 .^{\circ}$ do artigo 143 da Lei n. ${ }^{\circ} 8.112 / 90$.

Uma vez decididos os nomes dos servidores que integrarão a comissão, o próximo passo é a portaria instauradora.

José Armando da Costa sintetiza muito bem a função da portaria instauradora:

A Portaria é o instrumento adequado de que se utiliza a autoridade administrativa para formalizar a instauração do processo disciplinar. Além dessa função iniciatória do processo, a portaria instauradora constitui a comissão, designa o seu respectivo presidente e estabelece os limites da acusação (raio da acusação) ${ }^{413}$.

Somente a partir da publicação da portaria é que o processo se considera instaurado. Na portaria, são designados os membros da comissão, escolhendo-se o seu presidente entre os membros, indicando-se o objeto do processo (as irregularidades disciplinares trazidas ao conhecimento da autoridade hierárquica) e a individualização do acusado ou acusados.

A comissão deverá concentrar-se nos fatos que foram descritos na portaria, que é a peça inicial do processo, razão pela qual deve a portaria instauradora do processo administrativo disciplinar declinar, embora resumidamente, as irregularidades funcionais que forem atribuídas ao servidor acusado ${ }^{414}$.

${ }^{412}$ COSTA, 2010, p. 214-215.

${ }^{413}$ COSTA, 2010, p. 221.

${ }^{414}$ STF, Mandado de Segurança n. ${ }^{0}$ 25.105: "Ementa: Não se exige, na portaria de instauração de processo disciplinar, descrição detalhada dos fatos investigados, sendo considerada suficiente a delimitação do objeto 
Sebastião José Lessa observa que a portaria não pode ser tão sucinta a ponto de inviabilizar o contraditório e a ampla defesa (artigo 5. , LV, da Constituição Federal):

A propósito, a mera referência ao número de protocolo de determinado expediente não atende, por si só, o requisito de validade. Torna-se necessário que esse expediente noticie, mesmo de forma resumida, o fato, a autoria e a capitulação, em tese, da transgressão, viabilizando o exercício do contraditório e da ampla defesa ex vi do art. $5 .^{\circ}, \mathrm{LV}$, da Carta Política ${ }^{415}$.

\section{Diferente é o pensamento exposto por Marcos Salles Teixeira:}

[...] quanto à necessária indicação do alcance dos trabalhos, convém que a portaria apenas faça referência ao número do processo no qual estejam descritas as irregularidades e aos fatos conexos que possam emergir da apuração. Não é recomendável apontar na portaria o nome do servidor acusado e já cogitar da descrição do suposto ilícito e do enquadramento legal. Ao contrário de configurar qualquer prejuízo à defesa, tais lacunas na portaria preservam a integridade do próprio servidor envolvido e têm o fim de a autoridade instauradora não induzir o trabalho da comissão e de não propiciar alegação de préjulgamento. A indicação de que contra o servidor paira uma acusação é formulada pela comissão na notificação para que ele acompanhe o processo como acusado; já a descrição da materialidade do fato e o enquadramento legal da irregularidade (se for o caso) são feitos pela comissão em momento posterior, somente ao final da instrução contraditória, com a indiciação (refletindo convicção preliminar, passível de ser afastada pela defesa) ${ }^{416}$.

Francisco Xavier da Silva Guimarães defende o seguinte ponto de vista:

Urge, portanto, evitar que o ato constitutivo do procedimento apuratório disciplinar se converta em instrumento ensejador da presunção de culpabilidade pelo registro, desde logo, no corpo da portaria, das ocorrências tidas como possíveis ilícitos e seus respectivos dispositivos legais, como também, da indicação da provável autoria. A ausência que ora se preconiza preserva a imagem do servidor investigado da curiosidade alheia e evita nefastas influências externas sobre os trabalhos da comissão. É, portanto, medida que milita a favor do acusado ${ }^{417}$.

do processo pela referência a categorias de atos possivelmente relacionados a irregularidades". STJ, Mandado de Segurança n. ${ }^{\circ}$ 7.081: "Ementa: [...] IV - Inocorrência de nulidade quanto à portaria de instauração do processo disciplinar, seja porque fora proferida por autoridade no exercício de poder delegado, seja porque fez referências genéricas aos fatos imputados ao servidor, deixando de expô-los minuciosamente - exigência esta a ser observada apenas na fase de indiciamento, após a instrução". Ver ainda: STJ, Mandados de Segurança n. ${ }^{\circ} 6.853$, n. $^{\circ} 7.066$, n. $^{\circ} 8.146,{ }^{\circ}{ }^{\circ} 8.258,{ }^{\circ} .^{\circ} 8.858$ e n. ${ }^{\circ} 8.877$. Ver também: STF, recursos em Mandados de Segurança n. ${ }^{\circ} 2.203$, n. ${ }^{\circ} 2.501,{ }^{\circ}{ }^{\circ} 4.174,{ }^{\circ} .^{\circ} 4.504$ e n. ${ }^{\circ}$ 6998. STJ, Mandado de Segurança n. ${ }^{\circ}$ 12.369: "Ementa: II - A descrição minuciosa dos fatos se faz necessária apenas quando do indiciamento do servidor, após a fase instrutória, na qual são efetivamente apurados, e não na portaria de instauração ou na citação inicial”. Ver igualmente: STJ, Agravo Regimental no Recurso Especial n. ${ }^{\circ} 900.193$.

${ }^{415}$ LESSA, Sebastião José. Do processo administrativo disciplinar e da sindicância: doutrina, jurisprudência e prática. 5. ed. Brasília, DF: Brasília Jurídica, 2009, p. 126.

${ }^{416}$ TEIXEIRA, Marcos Salles. Anotações sobre processo administrativo disciplinar. Agosto 2014. Disponível em: 〈http://www.cgu.gov.br/Publicacoes/atividade-disciplinar/arquivos/rfb-anotacoessobrepad.pdf >. Acesso em: 24 out. 2014. p. 435-436.

${ }^{417}$ GUIMAR ÃES, Francisco Xavier da Silva. Regime disciplinar do servidor público civil da União. 2. ed. Rio de Janeiro: Forense, 2006, p. 112-113. 
Judivan Juvenal Vieira afirma: "Está pacificado pelos tribunais pátrios não ser necessário o detalhamento dos fatos [na portaria]. Basta a referência ao processo no qual a autoria e a materialidade será investigada" ${ }^{418}$.

Vinícius de Carvalho Madeira expõe o seguinte entendimento sobre o assunto:

[...] ao apenas fazer referência ao processo administrativo, a autoridade deu publicidade ao fato e delimitou o campo de atuação da comissão sem precisar expor a Administração, pois não divulgou a ocorrência de fatos irregulares que aconteceram, nem expôs o servidor acusado.

Assim, não há dúvidas de que atualmente, na portaria, basta conter a competência da autoridade instauradora, o nome dos membros da comissão e a remissão ao número do processo administrativo onde constam os fatos que serão apurados. Sugiro, por fim, que seja registrada na portaria a possibilidade de a comissão apurar fatos conexos - que têm ligação com o fato principal $[\ldots]^{419}$.

Nesse ponto, concorda-se com o entendimento exposto por Marcos Salles Teixeira. Não se faz necessária a descrição minuciosa dos fatos na portaria de instauração; ao invés de causar prejuízo à defesa, tais lacunas na portaria preservam a integridade do próprio servidor envolvido e têm o fim de fazer a autoridade instauradora não induzir o trabalho da comissão e de não propiciar alegação de pré-julgamento. É importante ressaltar que tal descrição deve ser feita apenas quando do indiciamento do servidor, após a fase instrutória, na qual são efetivamente apurados os fatos.

A comissão terá como secretário um servidor designado pelo seu presidente, podendo a indicação recair em um de seus membros (artigo 149, § 1. ${ }^{\circ}$, da Lei n. ${ }^{\circ} 8.112 / 90$ ).

Instaurado o processo, com a publicação do ato que constituir a comissão, deverá ficar concluído o trabalho apuratório no prazo de 60 dias, prorrogáveis por igual período, ou seja, no prazo máximo de 120 dias (artigo 152 da Lei n. ${ }^{\circ} 8.112 / 90$ ).

A fase do inquérito administrativo inicia-se com a subfase instrutória. Em tal momento, será realizada a primeira reunião da comissão, em cuja constância será deliberado a respeito das diligências a serem desencadeadas a fim de elucidar as irregularidades que são imputadas ao servidor acusado.

Ao serem decididas as primeiras providências, será lavrada, pelo secretário, a ata de instalação da comissão de processo, a qual deverá ser assinada por todos. Esse termo recebe também, na prática, a denominação "ata de início dos trabalhos da comissão de processo".

${ }^{418}$ VIEIRA, Judivan Juvenal. Processo administrativo disciplinar. São Paulo: IOB Thomson, 2005, p. 57.
${ }^{419}$ MADEIRA, Vinícius de Carvalho. Lições de processo disciplinar. São Paulo: Fortium, 2008, p. 82-84. 
A instrução tem por fim colher para o processo todos os elementos capazes de proporcionar-lhe um julgamento seguro, insuspeito e objetivo ${ }^{420}$.

Sintetizadas em atas as iniciais providências apuratórias a serem tomadas, deverá o acusado ser notificado ${ }^{421}$ a esse respeito, a fim de que possa comparecer ao local dos trabalhos, sendo assegurado ao servidor o direito de acompanhar o processo pessoalmente ou por intermédio de procurador, podendo assistir à tomada de depoimento das testemunhas, inquiri-las ou reinquiri-las, por intermediação do dirigente do processo, arrolar testemunhas, produzir provas e contraprovas, formular quesitos, quando se tratar de prova pericial (artigo 156 da Lei n. ${ }^{\circ} 8.112 / 90$ ).

Nessa subfase da instrução, deverão ser empreendidas todas as providências necessárias ao esclarecimento probatório da verdade dos fatos, como tomada de depoimentos, audição do denunciante (caso haja) e do acusado, colheita de provas documentais, realização de exames periciais, acareações, reconhecimento de pessoas ou coisas e outras mais. Como regra imprescindível, juntam-se ao processo as folhas de assentamentos funcionais dos servidores acusados.

Nas audiências de tomada de depoimentos, se o acusado estiver ausente, apesar de prévia e oportunamente notificado, a comissão processante deverá nomear um defensor $a d$ $h o c^{422}$.

Em princípio, todo o esforço probatório do processo concentra-se na fase em exame, embora não se desconheça que a defesa do indiciado, fazendo carrear ao processo substanciais elementos de convicção, constitua relevante força geratriz de comprovações $^{423}$.

Assim, a comissão poderá louvar-se em qualquer meio de provas permitido pelo direito, como exames periciais, documentos, indícios, reproduções mecânicas, acareação, reconhecimento de pessoas ou coisas, reprodução simulada do fato e outras provas mais.

É importante ressaltar que o acusado deve ser intimado com antecedência mínima de 3 dias úteis, a respeito de provas e diligências ordenadas pela comissão de inquérito,

\footnotetext{
${ }^{420}$ OCTAVIANO; GONZALES, 2009, p. 163.

${ }^{421}$ Com a publicação da portaria instauradora e a consequente notificação do servidor acusado, formada estará a relação processual disciplinar, dela defluindo relevantes efeitos jurídicos identificados por José Armando da Costa: interrupção da prescrição; dever de não se ausentar (artigo 162 da Lei n. ${ }^{\circ}$ 8.112/90); proibição de remoção; impossibilidade de exoneração a pedido (artigo 172 da Lei n. ${ }^{\circ}$ 8.112/90); impedimento de aposentadoria (artigo 172 da Lei n. ${ }^{\circ}$ 8.112/90) (COSTA, 2010, p. 225-229).

${ }^{422}$ Súmula Vinculante n. ${ }^{\circ} 5$ do Supremo Tribunal Federal. Será analisada mais adiante.

${ }^{423}$ Acrescente-se, de resto, que, mesmo em escala excepcional, ocorrem medidas instrutórias na fase do julgamento, nas hipóteses em que a autoridade julgadora, achando ainda obscuros alguns aspectos do processo, determina que sejam realizadas diligências a respeito, objetivando, naturalmente, dirimir tais dúvidas.
} 
mencionando-se data, hora e local de realização do ato, tudo por inteligência do artigo 26 , parágrafo $2 .^{\circ}$ da Lei n. ${ }^{\circ}$ 9.784, do artigo 156 da Lei n..$^{\circ}$ 8.112/90 e do MS 9.511 DF do STJ, publicado em 21 de março de 2005.

Considera-se o interrogatório do acusado como um ato de defesa. Por isso, deve ser o ato final da busca da convicção antes de a comissão deliberar indiciar ou propor o arquivamento do feito, funcionando como última oportunidade de o acusado tentar provar a sua inocência e não ser indiciado.

Pode-se afirmar que a subfase instrutória é a mais expressiva em matéria de esclarecimento dos fatos. As provas obtidas de modo ilícito não se prestam a instruir o processo administrativo disciplinar.

Concluída a instrução, os membros da comissão de processo analisarão as provas existentes nos autos do processo. Nesse momento processual, as provas serão examinadas e sopesadas pelos membros da comissão.

Se a comissão, ao examinar as provas existentes nos autos, chegar à conclusão de que as faltas disciplinares foram cometidas por outra pessoa, e não pelo servidor acusado, deverá, em exposição de motivos bem fundamentada, fazer os autos conclusos à autoridade instauradora, com a sugestão de que seja arquivado o processo.

Caso a autoridade instauradora concorde com a sugestão do arquivamento, será o acusado absolvido antecipadamente e instaurado novo processo para a responsabilização do servidor apontado como autor das faltas apuradas.

Na hipótese de a comissão reconhecer, com base nas provas dos autos, que os fatos são mesmo da autoria do servidor imputado, mas foram perpetrados em circunstâncias lícitas (estado de necessidade, legítima defesa e estrito cumprimento do dever legal ou no exercício regular de direito), deverá o processo, na mesma forma do caso anterior, ser submetido ao julgamento antecipado da autoridade instauradora, a qual, concordando com o ponto de vista do colegiado, absolverá o acusado e determinará o arquivamento do feito.

Se ficar comprovada a prática de transgressão disciplinar e houver suficientes elementos indicativos de que o acusado seja o seu autor, concluirá a comissão, nos termos do artigo 161 da Lei n. ${ }^{\circ}$ 8.112/90, pela sua indiciação, apontando, numa síntese escrita - o chamado "despacho de instrução e indiciação" -, as razões autorizadoras de tal ilação, bem como declinando as disposições da lei ou do regulamento em que deve ser feito o enquadramento: 
Art. 161. Tipificada a infração disciplinar, será formulada a indiciação do servidor, com a especificação dos fatos a ele imputados e das respectivas provas.

$\S 1 .^{\circ} \mathrm{O}$ indiciado será citado por mandado expedido pelo presidente da comissão para apresentar defesa escrita, no prazo de 10 (dez) dias, assegurando-se-lhe vista do processo na repartição.

$\S 2 .^{\circ}$ Havendo dois ou mais indiciados, o prazo será comum e de 20 (vinte) dias.

$\S 3 .^{\circ} \mathrm{O}$ prazo de defesa poderá ser prorrogado pelo dobro, para diligências reputadas indispensáveis.

$\S 4 .^{\circ}$ No caso de recusa do indiciado em apor o ciente na cópia da citação, o prazo para defesa contar-se-á da data declarada, em termo próprio, pelo membro da comissão que fez a citação, com a assinatura de (2) duas testemunhas.

O despacho de instrução e indiciação será assinado pelos membros da comissão e pelo secretário, abrindo-se, em seguida, prazo de dez dias para o oferecimento da defesa escrita, devendo o servidor indiciado, antes, ser devidamente citado por mandado expedido pelo presidente do colegiado processante (artigo 161, parágrafo $1 .^{\circ}$, da Lei n. ${ }^{\circ} 8.112 / 90$ ).

Comparando-se com o processo penal, o despacho de instrução e indiciação exerce função semelhante à da sentença de pronúncia no processo criminal, nos delitos de competência do júri.

A partir de então o servidor imputado passa à categoria de "indiciado", o que agrava a situação processual do acusado.

Para José Armando da Costa, o direito de defesa comporta duas acepções - a pessoal e a técnica:

A pessoal, devidamente consagrada nas normas e nos princípios jurídicos, consubstancia-se nos esforços defensórios empreendidos pelo próprio acusado, desde o limiar do processo. Inclui-se nessa acepção o acompanhamento pessoal do acusado às audiências feitas pela comissão para a tomada de depoimentos. Compreende, também, o seu desempenho na ocasião do interrogatório, em que procura convencer sobre sua versão dos fatos, a formulação de quesitos, quando haja prova pericial e outras providências mais. Enquanto que a defesa técnica configura um desempenho de natureza mais científico-jurídica, realizado em regra, pelos expertos em Direito. Nessa compreensão, a empreitada defensória do acusado encontra na defesa escrita o seu mais importante e expressivo logradouro ${ }^{424}$.

O artigo 161, § $1 .^{\circ}$, da Lei n. ${ }^{\circ} 8.112 / 90$ dispõe que a comissão de disciplina dará vista do processo ao indiciado, a fim de que elabore a sua defesa escrita.

Após ter vista dos autos e antes do oferecimento da defesa escrita, o indiciado poderá solicitar a realização de diligências (artigo 161, § $3^{\circ}$ da Lei n. ${ }^{\circ}$ 8.112/90). Tais

${ }^{424}$ COSTA, 2010, p. 250. 
diligências serão avaliadas pela comissão, podendo ser indeferidas em despacho fundamentado.

Apresentada a defesa, encerra-se a fase defensória, passando-se à fase do relatório conclusivo da comissão.

Os autos serão conclusos ao presidente da comissão, sendo submetidos a exame de todos os integrantes da comissão para a confecção do relatório conclusivo.

Segundo José Armando da Costa, o relatório ${ }^{425}$ da comissão tem três funções: informativa, opinativa e conclusiva. Explica o autor:

Consubstanciando um resumo de todas as providências tomadas dentro do processo, com remissão às folhas respectivas, concretiza o relatório do processo, sem dúvida, uma notável função informativa. Esta poderá colaborar com a autoridade hierárquica na tarefa do julgamento, ou, pelo menos, nos trabalhos de compulsar os autos. Em verdade, o relatório final da comissão tem função predominantemente informativa e conclusiva. Isso, porém, não exclui a sua atribuição opinativa. Daí porque deve a comissão registrar no relatório o dispositivo legal ou regulamentar que entende haver sido infringido pelo indiciado. Como já referido acima, o relatório serve também como parecer conclusivo. Este, ainda que não vincule obrigatoriamente, fornece grande apoio à decisão da autoridade julgadora $^{426}$.

O relatório será sempre conclusivo quanto à inocência ou à responsabilidade do servidor (artigo 165, § 1. ${ }^{\circ}$, da Lei n. $.^{\circ} 8.112 / 90$ ).

Em síntese, o inquérito administrativo (ou, simplesmente, inquérito), que é a parte contraditória do processo, conduzida autonomamente pela comissão, comporta os seguintes atos, na ordem: atos iniciais do inquérito (instalação da comissão processante, comunicação da instalação, designação do secretário); atos de instrução (notificação do servidor, depoimentos, perícias, diligências, interrogatório, indiciação e citação para apresentar defesa escrita); defesa escrita; relatório.

Concluído o relatório, será juntado ao processo e encaminhado à autoridade instauradora para a terceira fase: o julgamento.

\footnotetext{
425 José Armando da Costa enumera alguns aspectos que o relatório deve necessariamente mencionar: a) cumprimento do prazo ou prazos do processo, em conformidade com o que estabelece o artigo 152 da Lei n. ${ }^{\circ}$ $8.112 / 90$; b) ocorrências de procedimentos incidentes, como substituição de membros da comissão, nomeação de defensor de ofício, solicitação de abertura de inquérito policial etc.; c) localização da sede dos trabalhos da comissão, com a especificação dos possíveis deslocamentos; d) resumo das acusações que motivaram a instauração do processo disciplinar; e) menção das testemunhas ouvidas no processo, fazendose remissão às folhas dos autos; f) relação dos termos de acareações e reconhecimento de pessoas ou coisas, fazendo-se remissão às folhas dos autos; g) relação dos exames periciais, com as remissões necessárias às folhas dos autos do processo; h) síntese dos fatos catalogados na instrução indiciatória, realizada logo depois da conclusão da fase instrutória; i) razões apresentadas pela defesa, sua apreciação e consideração; j) conclusão pela inocência do acusado ou pela sua culpa, com a indicação dos dispositivos legais transgredidos e, se for o caso, afixação do valor dos prejuízos causados à Fazenda Nacional (COSTA, 2010, p. 263).

${ }^{426}$ COSTA, 2010, p. 262.
} 
A autoridade julgadora não está vinculada às conclusões das comissões de processo disciplinar. Tem a liberdade para julgar em sentido contrário e motivadamente, desde que a isso autorizem as provas existentes nos autos.

O artigo 168, parágrafo único, da Lei n. ${ }^{\circ} 8.112 / 90$ reza que a autoridade julgadora poderá "agravar a penalidade proposta, abrandá-la ou isentar o servidor de responsabilidade", desde que o faça de modo fundamentado.

Ressalta-se que as conclusões das comissões, desde que estejam baseadas nas provas dos autos, merecem fiel acatamento por parte da autoridade julgadora (artigo 168 da Lei n. $\left.{ }^{\circ} 8.112 / 90\right)$.

José Armando da Costa acentua que deve a autoridade, ao julgar, adotar as seguintes providências:

a) verificar se as conclusões do colegiado processante estão de acordo com as provas produzidas e coletadas;

b) examinar se alguma prova relevante ao esclarecimento dos fatos fora, como sói acontecer, desprezada pelos membros da comissão;

c) confrontar as opiniões dos órgãos de assessoramento já consultados, a fim de verificar se existem divergências entre elas;

d) solicitar parecer fundamentado do setor jurídico de sua repartição a respeito do processo;

e) analisar as razões invocadas pela comissão para indeferir pedidos de diligências requeridos pelos servidores acusados;

f) levar em conta que as dúvidas prevalecentes beneficiam os acusados, como bem assevera a velha e sempre atual parêmia de que a dúvida favorece o acusado (in dubio pro reo);

g) considerar que o depoimento de uma só testemunha não é bastante para fundamentar uma decisão condenatória (testis unus, testis nullus) ${ }^{427}$ :

Assim, a autoridade julgadora deverá decidir pela inocência do servidor ou por sua responsabilidade (indicando a respectiva pena).

\subsubsection{Sindicância}

José Armando da Costa noticia que "o termo 'sindicância' promana do latim syndicus, que, por sua vez, origina-se do grego syndikos, que denota a noção de examinar, inquirir, pesquisar e tomar informações, entre outros significados de simílima ou assemelhada compreensão" ${ }^{428}$.

\footnotetext{
${ }^{427}$ COSTA, 2010, p. 274, grifo do autor.
}

${ }^{428}$ COSTA, 2010, p. 317. 
Sindicância significa em português "operação cuja faculdade é trazer à tona, fazer ver, revelar ou mostrar algo, que se acha oculto" ${ }^{\text {}} 29$.

Genericamente, a palavra "sindicância" seria o conjunto de atos ou diligências empreendidos no seio de uma repartição pública, objetivando apurar o cometimento de possíveis irregularidades por parte de seus servidores.

A sindicância seria um procedimento investigatório rápido e sumário, cujos requisitos principais são: rapidez, objetividade, precisão. Na lição de José Cretella Júnior, sindicância administrativa seria:

O meio sumário de que se utiliza a Administração no Brasil para, sigilosa ou publicamente, com indiciados ou não, proceder à apuração de ocorrências anômalas no serviço público, as quais, confirmadas, fornecerão elementos concretos para a abertura do processo administrativo contra o funcionário público responsável; não confirmadas as irregularidades, o processo sumário é arquivado ${ }^{430}$.

O prazo da sindicância é de 30 dias, podendo ser prorrogado por mais 30 dias (artigo 145, parágrafo único, da Lei n. ${ }^{\circ} 8.112 / 90$ ).

Existem as seguintes espécies de sindicância: a) sindicância investigativa, preparatória ou Inquisitorial; b) sindicância acusatória, contraditória, autônoma, apuratória ou disciplinar; c) processo administrativo disciplinar decorrente de sindicância disciplinar ou sindicância preparatória ou conectiva.

Como a Lei Federal n. ${ }^{\circ}$ 8.745/93, que cuida dos servidores temporários, refere-se ao termo "sindicância" para a apuração das faltas dos referidos servidores, analisar-se-á cada uma das espécies citadas.

\subsubsection{Sindicância investigativa, preparatória ou inquisitorial}

Sindicância, historicamente, significa apuração de qualquer fato que tenha acontecido, em relação a qualquer matéria de que trate a administração pública. Seria um procedimento administrativo que tem por fim investigar ou com função preparatória. Possui uma natureza inquisitorial (sem a figura de acusado a quem se conceder ampla defesa e contraditório).

Marcos Salles Teixeira anota que a sindicância investigativa a ser empregada como um procedimento sigiloso em fase de admissibilidade "pode ser instaurada por meio de

\footnotetext{
${ }^{429}$ CRETELLA JÚNIOR, 2009, p. 64.

${ }^{430}$ CRETELLA JÚNIOR, 2009, p. 64-68.
} 
desnecessária publicidade, designando-se apenas um sindicante ou uma comissão com número de integrantes a critério da autoridade competente" ${ }^{\text {431 }}$.

$\mathrm{Na}$ modalidade inquisitorial, a sindicância é aberta quando não se dispõe de informações suficientes, são imprecisas as notícias sobre possíveis irregularidades funcionais.

A espécie de sindicância inquisitorial, além de não possuir contraditório, é realizada de forma sigilosa e discricionária ${ }^{432}$, o que lhe retira a característica de processo. Em razão disso, a sindicância inquisitorial não pode ser utilizada para aplicação de nenhuma penalidade.

A sindicância inquisitorial pode ser instaurada por qualquer autoridade administrativa, não está prevista na Lei n. ${ }^{\circ}$ 8.112, de 11 de dezembro de 1990, não há um rito específico; por isso, adota, quando possível, os institutos, rito e prazos da sindicância contraditória.

Ressalte-se que a sindicância inquisitorial não se confunde com a sindicância contraditória, prevista nos artigos 143 e 145 da Lei n. ${ }^{\circ}$ 8.112/90.

Sobre a utilidade da sindicância inquisitorial, são válidas as observações de Marcos Salles Teixeira:

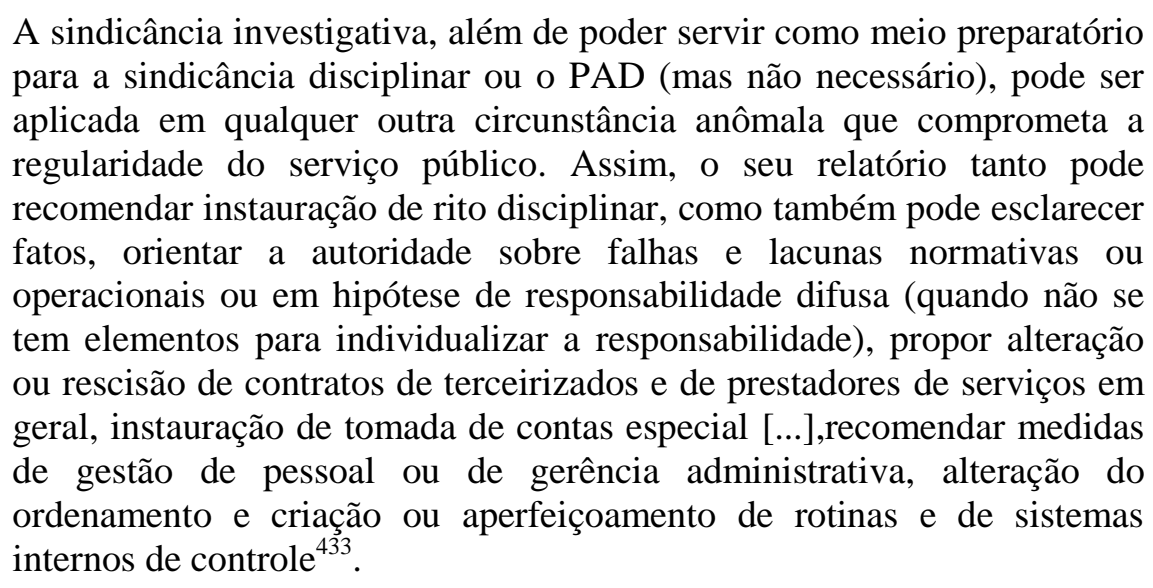

José Armando da Costa ressalta que "o surgimento de comprovações indicadoras da autoria das irregularidades funcionais coroa o êxito da sindicância inquisitorial" "434. Como conclusão da sindicância inquisitorial surgirão as seguintes situações:

\footnotetext{
431 TEIXEIRA, 2014, p. 127.

432 José Armando da Costa entende que se impõe o sigilo a fim de preservar a dignidade do serviço público, bem como para tornar mais eficientes os trabalhos investigatórios. Já a discricionariedade assegura que as investigações sejam realizadas nos moldes definidos pelo sindicante, sem sujeição a ritos preestabelecidos, o que não implica contemporizar, prepotências e desmandos (COSTA, 2010, p. 322).

433 TEIXEIRA, 2014, p. 127.

${ }^{434}$ COSTA, 2010, p. 322.
} 
a) dependendo da gravidade da infração poderá ser sugerida a abertura de sindicância autônoma ou do processo disciplinar;

b) inexistência de indícios sobre irregularidades veiculadas, o que conduzirá ao arquivamento da sindicância inquisitória.

É importante ressaltar que a sindicância pode ser desarquivada assim que surjam novas comprovações, observada a prescrição.

Se, no decorrer dos trabalhos, o sindicante ou a comissão de sindicância concluir que se trata de irregularidade administrativa, ainda que preliminarmente, deve representar à autoridade instauradora, propondo instauração de procedimento disciplinar, conforme determina o artigo 143 da Lei n. ${ }^{\circ}$ 8.112, de 11 de dezembro de 1990.

5.2.2.2 Sindicância contraditória, acusatória, autônoma, apuratória ou disciplinar da Lei n. ${ }^{\circ}$ 8.112, de 11 de dezembro de 1990

A sindicância contraditória é um meio célere para apurar fatos irregulares de menor gravidade.

José Armando da Costa apresenta as seguintes características da sindicância autônoma:

\begin{abstract}
A sindicância autônoma é aquela instaurada à vista de uma acusação formal contra determinado servidor ou determinados servidores. Rege-se pelo devido processo legal desde o seu nascedouro. E assegura, em todos os seus momentos, ampla defesa aos servidores imputados. Bem como serve de lastro à edição do respectivo ato punitivo, conquanto que a punição seja de advertência ou de suspensão de até 30 (trinta) dias ${ }^{435}$.
\end{abstract}

Embora não haja um rito próprio para a sindicância disciplinar, como pode haver punição (advertência e suspensão de até trinta dias), há necessidade de se garantir o devido processo legal, o contraditório e a ampla defesa. A solução encontrada foi estender para a sindicância disciplinar o rito que a própria Lei previu para o processo administrativo disciplinar. José Armando da Costa chega a dizer: "No mais, deve o rito processual da sindicância inspirar-se nas fases do processo disciplinar"436.

A Lei n. ${ }^{\circ} 8.112$, de 11 de dezembro de 1990, instituiu a sindicância, sem especificar o seu rito, apenas indicou algumas características do processo administrativo disciplinar, como o prazo de conclusão e o alcance das penas. O prazo para a conclusão da sindicância é de até trinta dias a partir da instauração, prorrogáveis por igual período, para aplicação

\footnotetext{
${ }^{435}$ COSTA, 2010, p. 322.

${ }^{436}$ COSTA, 2010, p. 327.
} 
das penas estatutárias brandas. No processo administrativo disciplinar, o prazo para a sua conclusão dobra para até sessenta dias a partir da instauração, prorrogáveis por igual período, para aplicação de qualquer pena estatutária, branda ou grave.

De conformidade com o artigo 145 da Lei n. ${ }^{\circ}$ 8.112/90, a sindicância pode resultar em proposta de arquivamento, de punição com advertência ou suspensão de até trinta dias ou de abertura de processo administrativo disciplinar. No caso de processo administrativo disciplinar, é possível aplicar pena de suspensão superior a trinta dias, de demissão ou cassação de aposentadoria ou de disponibilidade ou de destituição do cargo em comissão (artigo 146 da Lei n. $\left.{ }^{\circ} 8.112 / 90\right)$.

A sindicância, apesar de ser mais célere e menos formal, constitui, na sua modalidade autônoma, verdadeiro processo.

As fases da sindicância disciplinar são as mesmas fases do processo administrativo disciplinar: instauração, instrução, defesa, relatório e julgamento. Repita-se que, na sindicância, devem ser respeitados os princípios do devido processo legal, do contraditório, da ampla defesa. José Armando da Costa afirma que "tais fases deverão, mutatis mutandis, observar os mesmos princípios, normas e cuidados que orientam, nesse particular, o processo disciplinar. A sindicância inquisitorial - por ainda não ser processo - fica fora desse ritualismo" ${ }^{437}$.

Aplicar-se-á à sindicância, praticamente, o mesmo procedimento do processo administrativo disciplinar, o que se analisará resumidamente nesta subseção.

Deve haver justa causa para a abertura de sindicância autônoma ou conectiva, ou seja, indícios de provas. Sem esse mínimo legal, poder-se-ão instaurar sindicâncias inquisitoriais.

Não há expressa determinação legal sobre a comissão de sindicância. Entende-se que a sindicância deve ser realizada por uma comissão regularmente constituída, ou seja, um colegiado processante. Na modalidade inquisitorial, pode haver a instauração de sindicância singular, conduzida por agente sindicante.

Não se pode esquecer que algumas passagens da Lei n. ${ }^{\circ} 8.112 / 90$ referem-se à comissão de sindicância. Assim, entende-se que, no caso de sindicância contraditória, deve haver no mínimo dois membros, mas, por analogia ao processo administrativo disciplinar, melhor seria se a comissão fosse constituída por três membros. A sindicância investigativa pode ser conduzida por apenas um membro (sindicante). Além disso, na sindicância

${ }^{437}$ COSTA, 2010, p. 324. 
composta por comissão, há mais segurança e garantia do que na sindicância formada por um agente sindicante.

Como no rito do processo administrativo disciplinar, a portaria instauradora da sindicância, entre outras funções, designa a comissão ou o sindicante, faz uma síntese das irregularidades a serem apuradas e individualiza o acusado.

O acusado deve ser notificado para integrar a relação processual disciplinar.

Na fase de instrução da sindicância, a comissão deverá apurar os fatos, promovendo a tomada de depoimentos, acareações, investigações, perícias, enfim, todos os meios de prova admitidos em direito.

O sindicado deverá ser notificado sobre a realização de todas as diligências, tendo o direito de acompanhar os trabalhos apuratórios pessoalmente ou por meio de procurador, podendo arrolar e reinquirir testemunhas, produzir provas, elaborar quesitos.

Assim como no processo administrativo disciplinar, caso o servidor imputado não compareça, apesar de devidamente notificado, ser-lhe á nomeado um defensor dativo, evitando-se possíveis nulidades ${ }^{438}$.

Concluída a instrução, se ficar comprovada a prática de transgressão disciplinar e houver suficientes elementos indicativos de que o sindicado seja o seu autor, deverá a comissão sindicante formalizar, com a articulação sintética dos fatos e a individuação da respectiva autoria, o despacho de instrução e indiciação, devendo o sindicante ser citado para a apresentação de defesa no prazo de 10 dias. Se a comissão sindicante chegar a outra conclusão, deverá providenciar o despacho concluindo pelo arquivamento da sindicância.

Citado, o sindicado deverá apresentar defesa. A comissão receberá a defesa e analisará as provas contidas nos autos. Após o exame das provas, a comissão elaborará o relatório final, com sua conclusão sobre os fatos.

Constatada a responsabilidade disciplinar do sindicado, a comissão deverá especificar o dispositivo infringido, bem como as circunstâncias agravantes e atenuantes, se houver.

Em seguida, os autos da sindicância serão remetidos à autoridade julgadora, a qual julgará o caso, acatando as conclusões da comissão, ou decidindo de modo diferente, quando o relatório da comissão contrariar as provas dos autos, ou absolvendo o servidor indiciado.

${ }^{438}$ A Súmula Vinculante n. ${ }^{\circ} 5$ do Supremo Tribunal Federal será analisada na subseção 5.3.2. 
Pode-se, então, dizer que sindicância e processo administrativo disciplinar são muito semelhantes, o que muda somente é que a sindicância destina-se a apurar faltas cuja punição poderá resultar em aplicação de penalidade de advertência ou de suspensão de até 30 (trinta) dias; poderá haver o arquivamento do processo ou a instauração de processo disciplinar.

José Armando da Costa sustenta a impossibilidade de aplicação extensiva de restrições:

Os princípios, normas e regras do processo disciplinar, mutatis mutandis, aplicam-se supletivamente ao procedimento da sindicância. Tal enfoque geral deverá, porém, abrir espaço ao princípio de que as disposições restritivas de direito e da liberdade do indivíduo devam receber interpretação estrita. O que implica a proibição de se fazer qualquer ampliação de restrições (benigna amplianda, odiosa restringenda). As disposições benignas podem ser ampliadas, já as restritivas devem conterse nos limites estritos de sua literalidade ${ }^{439}$.

O referido autor exemplifica: o afastamento preventivo somente pode ser ordenado no processo disciplinar (artigo 147 da Lei n. ${ }^{\circ}$ 8.112/90), não podendo ser estendido aos acusados em sindicância. O mesmo tratamento ocorre em relação ao artigo 172 da Lei n. ${ }^{\circ}$ 8.112/90, cuja disposição preceitua que o servidor acusado em processo disciplinar somente poderá ser exonerado a pedido, ou aposentado voluntariamente, após a conclusão do feito. Como essas restrições são destinadas, de forma expressa, aos servidores que respondem a processo disciplinar, não podem ser aplicadas aos servidores envolvidos em sindicância.

5.2.2.3 Processo administrativo disciplinar decorrente de sindicância disciplinar ou de sindicância preparatória ou conectiva

Nas palavras de José Armando da Costa: “A sindicância preparatória, ou conectiva, é aquela que, guardando todas as características da sindicância autônoma, serve como elemento de interligação para a inauguração do processo disciplinar" ${ }^{440}$.

Nessa sindicância, apenas ao final do procedimento é possível apurar a gravidade das infrações cometidas. Ao ultrapassar os limites previstos em lei para a sindicância autônoma - observa-se que as transgressões cometidas são passíveis de aplicação de uma suspensão superior a 30 dias, demissão, cassação de aposentadoria ou disponibilidade, ou

\footnotetext{
${ }^{439}$ COSTA, 2010, p. 330, grifos do autor.

${ }^{440}$ COSTA, 2010, p. 322-323.
} 
destituição de cargo em comissão), devem tais transgressões disciplinares ser apuradas por meio do processo administrativo disciplinar ordinário ou sumário.

Havendo indícios de irregularidade grave, deve a comissão de sindicância solicitar de imediato à autoridade instauradora a conversão em processo administrativo disciplinar. Tanto na sindicância inquisitorial quanto na contraditória, devem ser refeitos os atos de instrução probatória, considerados importantes, realizados no primeiro procedimento sem que se tenha oportunizado ao acusado o direito à ampla defesa e ao contraditório, a fím de que tenham valor de prova no processo administrativo disciplinar.

A sindicância preparatória ou conectiva nasce como autônoma e transforma-se em processo disciplinar estrito (ordinário ou sumário).

\subsubsection{Processo disciplinar sumário}

O rito sumário foi introduzido pela Lei n. ${ }^{\circ}$ 9.527, de 10 de dezembro de 1997. Aplica-se o procedimento sumário para apuração de acumulação ilegal de cargos, de abandono de cargo e de inassiduidade habitual, sendo em todos os casos cabível a pena de demissão.

Como nesses casos a materialidade já está pré-constituída, espera-se que seja uma instrução célere, ultrapassando algumas etapas do rito ordinário, mas sempre observando o contraditório e a ampla defesa.

Se for necessário contestar a prova pré-constituída, nada impede que a defesa provoque formação de provas como no rito ordinário (artigo $133, \S 8 .^{\circ}$, da Lei n. ${ }^{\circ}$ 8.112/90), com oitivas, diligências, interrogatório, etc., sem prejuízo das prerrogativas da comissão de denegar aqueles pedidos impertinentes ou protelatórios, conforme o artigo $156, \S 1 .^{\circ}$, da Lei n. ${ }^{\circ} 8.112$, de 11 de dezembro de 1990 :

STJ. Mandado de Segurança n. ${ }^{0}$ 7.464: "Ementa: [...] III - A intenção do legislador - ao estabelecer o procedimento sumário para a apuração de abandono de cargo e de inassiduidade habitual - foi no sentido de agilizar a averiguação das referidas transgressões, com o aperfeiçoamento do serviço público. Entretanto, não se pode olvidar das garantias constitucionalmente previstas. Ademais, a Lei n. ${ }^{\circ} 8.112 / 90$ - art. 133, § $8 .^{\circ}$ - prevê, expressamente, a possibilidade de aplicação subsidiária no procedimento sumário das normas relativas ao processo disciplinar.

O rito sumário inicia-se com a portaria de instauração que define o fato a apurar. 


\subsubsection{Rito para acumulação ilegal de cargos}

Identificado o caso de acumulação ilegal, a autoridade instauradora deve notificar o servidor, por intermédio de sua chefia imediata, a fim de que, no prazo de dez dias, ele opte por um dos cargos (artigo 133 da Lei n. ${ }^{\circ}$ 8.112/90). Fazer a opção pelo outro cargo implica exoneração a pedido do cargo ocupado no próprio órgão. Se a opção for pelo cargo ocupado no próprio órgão, deve-se aguardar pela comprovação da exoneração do outro cargo.

É importante ressaltar que a proibição da acumulação remunerada também se estende aos proventos da aposentadoria, nada obsta a que o aposentado que se encontra na situação de acumulação ilícita opte pelo cargo, renunciando àqueles proventos.

Frise-se que somente se o interessado não fizer a opção por um dos cargos é que se instaura o processo sumário, com comissão integrada por dois servidores estáveis.

Como a prova é pré-constituída, a portaria de instauração já deve indicar a autoria e a materialidade. Logo, deve conter a identificação do servidor, a descrição dos cargos, dos órgãos, das datas de ingresso, dos horários e dos regimes de trabalho (artigo 133, § 1. ${ }^{\circ}$, da Lei n. $\left.{ }^{\circ} 8.112 / 90\right)$.

Até três dias antes da instauração do processo, a comissão providenciará o termo de indiciação do servidor, promovendo a sua citação para apresentar defesa em cinco dias (artigo 133, § 2. ${ }^{\circ}$, da Lei n. $\left..^{\circ} 8.112 / 90\right)$.

Uma vez apresentada defesa sem pedido de realização de diligências, busca de provas, em cinco dias a comissão deve elaborar o relatório conclusivo acerca da inocência ou da responsabilidade do servidor, opinando sobre a licitude ou não da acumulação (artigo $133, \S 3 .^{\circ}$, da Lei n. $\left.{ }^{\circ} 8.112 / 90\right)$.

A opção pelo servidor até o último dia de defesa configura boa-fé e implica apenas exoneração a pedido do outro cargo (artigo 133, § 5. ${ }^{\circ}$, da Lei n. ${ }^{\circ} 8.112 / 90$ ).

Se o servidor não manifesta a sua opção e se o procedimento sumário apresenta um relatório caracterizando a ilegalidade de acumulação, deve a autoridade promover sua demissão de ambos os cargos, empregos ou funções públicas que ocupa irregularmente (artigo 133, § 6..$^{\circ}$, da Lei n. $.^{\circ} 8.112 / 90$ ).

Um exemplo de caso em que há boa-fé são manifestações divergentes acerca da legalidade da acumulação ou mera aparência de que se trata de matéria de caráter técnico 
efetivo. Há má-fé quando, ao ser provido em um cargo, o servidor não declarar o fato de já ocupar outro $^{441}$.

Em cinco dias do recebimento do processo, a autoridade julgadora analisa aspectos formais do processo e, se for o caso, remete os autos à Consultoria Jurídica do órgão, uma vez que o ilícito enseja pena expulsiva, a cargo do respectivo Ministro de Estado (artigo 133, § 4. ${ }^{\circ}$, da Lei n. $\left.{ }^{\circ} 8.112 / 90\right)$.

O prazo para a conclusão do procedimento administrativo disciplinar de rito sumário é de trinta dias, contados da instauração, prorrogáveis por mais quinze dias (artigo $133, \S 7 .^{\circ}$ e $\S 8 .^{\circ}$, da Lei n. $\left.{ }^{\circ} 8.112 / 90\right)$.

\subsubsection{Rito para abandono de cargo e inassiduidade habitual}

A apuração do abandono de cargo e da inassiduidade habitual segue quase o mesmo rito adotado para a acumulação ilegal, previsto no artigo 133 da Lei n. ${ }^{\circ} 8.112$, de 11 de dezembro de 1990, não sendo adotada a prévia ou a posterior manifestação configuradora de boa-fé e outras particularidades, pois o artigo 140 contém algumas disposições específicas em relação a dispositivos do artigo 133.

A própria lei já define o que é considerado abandono de cargo: a ausência intencional do servidor ao serviço por mais de trinta dias consecutivos (artigo 138 da Lei n..$^{\circ}$ 8.112/90). Entende-se por inassiduidade habitual a falta ao serviço, sem causa justificada, por sessenta dias, interpoladamente, durante o período de doze meses (artigo 139 da Lei n. ${ }^{\circ}$ 8.112/90).

No caso do abandono de cargo, a indicação da materialidade na portaria de instauração faz-se com o registro preciso do período de ausência intencional superior a trinta dias. Isto é, indica-se o primeiro e o último dia de ausência ininterrupta, sem um único dia de efetivo exercício do cargo.

A conclusão da comissão deve levar em consideração tanto a comprovação do quantitativo de ausência continuada, quanto a comprovação da intencionalidade ou não da ausência superior a trinta dias consecutivos. Ressalta-se que a Lei não exige animus de abandono definitivo.

Se a comissão não comprovar a intenção (elemento essencial) do servidor de ausentar-se do serviço por mais de trinta dias, não poderá aplicar a pena de demissão por

${ }^{441}$ GUIMARÃES, 2006, p. 80. 
abandono do cargo, com base nos artigos 132, II, e 138 da Lei n. ${ }^{\circ} 8.112$, de 11 de dezembro de 1990. Cabe outro enquadramento, por exemplo, falta de pontualidade ou de assiduidade, do artigo $116, \mathrm{X}$, da Lei n. $^{\circ}$ 8.112/90, ou, caso não caiba nenhum enquadramento, restará apenas o efeito pecuniário da ausência.

No caso de inassiduidade habitual, a indicação da materialidade na portaria de instauração faz-se com o registro preciso dos sessenta dias (ou mais) de falta sem causa justificada em um período de doze meses.

Observa-se que, para a configuração da inassiduidade habitual, a Lei exige a descrição da materialidade com a indicação individualizada de cada um dos sessenta dias úteis, não se incluindo fins de semana, feriados e dias de ponto facultativo, intercalados entre dias de ausência.

A conclusão da comissão deve levar em consideração, além da comprovação do quantitativo de faltas, algum motivo para as mínimas sessenta faltas interpoladas em doze meses e verificar se esse motivo realmente é suficiente para justificá-las.

Se existirem motivos relevantes, aceitáveis e razoáveis para justificar as faltas, não há enquadramento nos artigos 132, III, e 139 da Lei n. ${ }^{\circ}$ 8.112/90; poderá haver, por exemplo, falta de pontualidade ou de assiduidade, enquadrada no artigo 116, X, do Estatuto. Se não houver outro enquadramento, caberá apenas efeito pecuniário.

Assim, foram descritos os meios de apuração de faltas (processo administrativo disciplinar ordinário, processo disciplinar sumário, sindicância ordinária) dos servidores públicos padrão, em geral. Posteriormente, será abordado o processo administrativo disciplinar especial ou a sindicância especial para os servidores públicos temporários, ressaltando-se suas particularidades e diferenciações.

\subsection{CONSIDERAÇÕES SOBRE O DEVIDO PROCESSO LEGAL, O CONTRADITÓRIO E A AMPLA DEFESA}

Em todos os procedimentos para a apuração de faltas de servidores públicos (devese fazer aqui uma ressalva, pois, na sindicância inquisitorial, não há contraditório, o que lhe retira a característica de processo, não podendo ser utilizada para aplicação de nenhuma penalidade), é obrigatória a observância do devido processo legal, do contraditório e da ampla defesa. 
Embora o artigo 143 da Lei n. $^{\circ} 8.112 / 90$ assegure a ampla defesa durante todo o processo, o artigo 153 da mesma garante o contraditório apenas na segunda fase do processo (inquérito administrativo, envolvendo a instrução, a defesa e o relatório).

Logo, na fase de instauração, que compete à autoridade instauradora, após exame de admissibilidade, não há espaço para o contraditório, nem na última fase do processo - o julgamento tampouco é abrangido pelo contraditório. O contraditório está restrito ao inquérito administrativo.

\subsubsection{Devido processo legal}

O princípio do devido processo legal (due process of law) é um verdadeiro instrumento para preservar direitos e assegurar garantias aos servidores públicos.

Ada Pellegrini Grinover, ao fazer um histórico do "devido processo legal", noticia:

A análise histórica das garantias do "devido processo legal" demonstra que elas nasceram e foram cunhadas para o processo penal, onde se fazia sentir com mais urgência a preocupação com os direitos do acusado. Mas, a partir do art. 39 da Magna Carta de 1212, um longo caminho evolutivo levou, primeiro, ao reconhecimento da aplicabilidade das garantias ao processo civil e, posteriormente, ao processo administrativo punitivo. Este último passo foi dado graças à generosa tendência rumo à denominada "jurisdicionalização do processo administrativo", expressão relevante do aperfeiçoamento do Estado de Direito, correspondendo ao princípio da legalidade a que está submetida a administração pública e aos princípios do contraditório e da ampla defesa, que devem preceder toda e qualquer imposição de pena ${ }^{442}$.

Rogério Lauria Tucci e José Rogério Cruz e Tucci entendem que o devido processo legal é imperioso em um Estado de Direito, enfatizando o que o caracteriza:

a) elaboração regular e correta da lei, bem como de sua razoabilidade, sendo de justiça e enquadramento nas preceituações constitucionais (substantive due process of law, segundo o desdobramento da concepção norte-americana);

b) aplicação judicial da lei através de instrumento hábil à sua interpretação e realização, que é o processo (judicial process);

c) assecuração, neste, da paridade de armas entre as partes, visando a igualdade substancial $^{443}$.

A teoria do devido processo legal, tal qual construída na jurisprudência da Suprema Corte dos Estados Unidos, envolve duas vertentes: substantive due process e procedural

${ }^{442}$ GRINOVER, Ada Pellegrini. Do direito de defesa em inquérito administrativo. Revista de Direito Administrativo, Rio de Janeiro, n. 183, jan./mar. 1991, p. 9.

${ }^{443}$ TUCCI, Rogério Lauria; CRUZ E TUCCI, José Rogério. Constituição de 1988 e processo: regramentos e garantias constitucionais do processo. São Paulo: Saraiva, 1989, p. 17, grifos dos autores. 
due process. A primeira é a projeção do princípio no campo do direito material, já a segunda funciona como garantia na esfera processual ${ }^{444}$.

Existem duas abordagens do princípio da razoabilidade: a primeira, influenciada pela jurisprudência norte-americana, liga o princípio da razoabilidade ao do devido processo legal e ao da isonomia; a segunda, por sua vez, seguindo a linha do direito francês, espanhol e argentino, identifica a razoabilidade com o princípio da proporcionalidade entre os meios e os fins.

É importante ressaltar que, quando se associa a razoabilidade ao devido processo legal, o princípio representa mais um limite à discricionariedade na função legislativa; quando se relaciona a razoabilidade com a proporcionalidade entre os meios e os fins, o princípio apresenta-se mais como limite à discricionariedade administrativa ${ }^{445}$.

O devido processo legal atingiu o seu ponto mais alto na Constituição Federal de 1988, no artigo 5. ${ }^{\circ}, \mathrm{LV}$, que reza: “Aos litigantes, em processo judicial ou administrativo, e aos acusados em geral são assegurados o contraditório e a ampla defesa com os meios e recursos a ela inerentes".

Rogério Lauria Tucci e José Rogério Cruz e Tucci entendem o devido processo legal como uma garantia: “A garantia constitucional do devido processo legal deve ser uma realidade em todo o desenrolar do processo judicial, de sorte que ninguém seja privado de seus direitos, a não ser que no procedimento em que este se materializa se verifiquem todas as formalidades e exigências em lei previstas"

Atualmente, não se admite que o servidor venha a ser apenado sem que lhe seja propiciada a oportunidade de oferecer todos os motivos que justifiquem ou, ao menos, expliquem seu comportamento.

Nesse sentido, José Armando da Costa ressalta:

O devido processo legal (due process of law), como garantia de ordem constitucional (art. $5 .^{\circ}, \mathrm{LIV}$, da CF), exige, como pressuposto básico, que o procedimento, qualquer que seja (civil, penal, administrativo e outros), observe, desde o seu nascedouro, os limites da acusação ou do pedido que foi deduzido nessas peças inaugurais, constituindo essa função delimitadora de tais exordiais o mais expressivo traço caracterizador do processo moderno, democrático e legítimo ${ }^{447}$.

\footnotetext{
${ }^{444}$ ALVIM, Angélica Arruda. Princípios constitucionais do processo. Revista de Processo, São Paulo, v. 19, n. 74, abr./jun. 1994, p. 21-22.

445 DI PIETRO, 2001, p. 191.

446 TUCCI; CRUZ E TUCCI, 1989, p. 15-16, grifo dos autores.

${ }^{447}$ COSTA, 2010, p. 222.
} 
Como direitos inerentes ao devido processo - ao due process of law -, podem-se enumerar: cientificação do processo ao interessado; direito a ser ouvido; direito de fazer-se representar por profissional especializado; direito a oferecer e produzir a prova adequada à defesa de suas pretensões; direito a participar na produção da prova feita pela Administração; direito de contestar; direito de recorrer.

Em suma, num Estado Democrático de Direito, o devido processo legal deve significar o afastamento de arbitrariedades e de privilégios para alguma das partes, sob pena de ser necessário refazer todo o processo.

Odete Medauar afirma que, no concernente aos sujeitos, o devido processo legal significa "o conjunto de garantias que lhes são propiciadas para tutela de posições jurídicas ante a Administração. Sob o ângulo do poder público consiste na obrigatoriedade de atuar mediante processo em determinadas situações" ${ }^{448}$.

Em seguida, a referida autora conclui que a combinação dos incisos LIV e LV do artigo 5..$^{\circ}$ da CF implica a imposição de processo administrativo que ofereça aos sujeitos oportunidade de apresentar sua defesa, suas provas, de contrapor seus argumentos e outros, enfim, a possibilidade de influir na formação do ato final. O devido processo legal desdobra-se, sobretudo, nas garantias do contraditório e da ampla defesa, aplicadas ao processo administrativo.

Segundo Ana Maria Rodrigues Barata, o devido processo legal disciplinar eficaz consiste "em assegurar que a falta praticada pelo servidor acusado obtenha tratamento processual, o que significa que a administração deve instaurar um processo para apurar qualquer infração de que tenha conhecimento"449.

Assim, o devido processo legal exerce uma grande influência na vida e nos direitos dos indivíduos. Apresenta um caráter indispensável a todas as garantias e exigências inerentes ao processo e deve ser observado no processo de apuração das faltas disciplinares dos servidores públicos temporários na sua totalidade.

\footnotetext{
${ }^{448}$ MEDAUAR, Odete. A processualidade no direito administrativo. São Paulo: Revista dos Tribunais, 1993, p. 83.

${ }^{449}$ BARATA, Ana Maria Rodrigues. A Súmula Vinculante n. 5 do Supremo Tribunal Federal e a defesa técnica por advogado no processo administrativo disciplinar. Revista do Ministério Público do Estado do Pará, Belém, Ano III, v. 1, dez. 2008, p. 64.
} 


\subsubsection{Contraditório e ampla defesa}

Comparando-se a Constituição Federal de 1967 com a Carta Política atual, nota-se uma alteração profunda, pois a de 1967, com redação dada pela Emenda de 1969, em seu artigo 153, $\S 15$, assegurava aos acusados "ampla defesa, com os recursos a ela inerentes". O artigo 153, § 16, previa o contraditório, mas apenas para a instrução criminal.

Mas, apesar disso, as garantias do contraditório e da ampla defesa para o processo não penal e para os acusados em geral, em processos administrativos, já eram defendidos pela doutrina e pela jurisprudência, nos textos constitucionais anteriores.

Já a Lei Maior de 1988, em seu artigo 5. ${ }^{\circ}$, inciso LV, ampliou o tratamento do tema e explicitamente dispôs: “Aos litigantes, em processo judicial ou administrativo, e aos acusados em geral são assegurados o contraditório e a ampla defesa, com os meios e recursos a ela inerentes".

E o que a Constituição quer dizer com os termos "litigantes" e "acusados"? Com muita propriedade, Ada Pellegrini Grinover explica:

Assim, a Constituição não mais limita o contraditório e a ampla defesa aos processos administrativos (punitivos) em que haja acusados, mas estende as garantias a todos os processos administrativos, não-punitivos e punitivos, ainda que neles não haja acusados, mas simplesmente litigantes ${ }^{450}$.

Sem dúvida, houve um alargamento do direito, assegurando o contraditório e a ampla defesa tanto no processo judicial quanto no processo administrativo, ao passo que, no Diploma Constitucional de 1967, eram previstos apenas no processo judicial.

E isso ocorreu em razão das tendências atuais do Direito Administrativo.

Ora, se a Constituição assegura a ampla defesa em processo administrativo, o servidor pode alegar tudo aquilo que lhe seja útil em sua defesa.

Ada Pellegrini Grinover aponta as linhas fundamentais dos procedimentos administrativos:

a) a publicidade dos procedimentos; b) o direito de acesso aos autos administrativos; c) a condenação do silêncio, com sanções aos responsáveis; d) a obrigação de motivar; e) a obrigatoriedade de contraditório e defesa na formação de atos pontuais restritivos de direitos e de atos compositores de conflitos e interesses ${ }^{451}$.

\footnotetext{
${ }^{450}$ GRINOVER, 1991, p. 13.
}

${ }^{451}$ GRINOVER, 1991, p. 12. 
O contraditório e a ampla defesa, assegurados no artigo $5^{\circ}{ }^{\circ}, \mathrm{LV}$, da Constituição Federal, decorrem do princípio do devido processo legal (due process of law) enunciado no artigo 5. ${ }^{\circ}$, LIV, da Lei Maior. E, por garantia de defesa, na lição de Hely Lopes Meirelles, deve-se entender "não só a observância do rito adequado, como a cientificação do processo ao interessado, a oportunidade para contestar a acusação, produzir provas de seu direito, acompanhar os atos da instrução e utilizar-se dos recursos cabíveis" ${ }^{452}$.

Essas garantias constitucionais são asseguradoras e especificadoras do devido processo legal, cabendo salientar ser a regra constitucional taxativa: tais garantias aplicamse ao processo administrativo.

Para Ada Pellegrini Grinover, deve haver a interação entre defesa e contraditório, nos seguintes termos:

Num determinado enfoque, é inquestionável que é do contraditório que brota a própria defesa. Desdobrando-se o contraditório em dois momentos - a informação e a possibilidade de reação -, não há como negar que o conhecimento, ínsito no contraditório, é pressuposto para o exercício da defesa. Mas, de outro ponto de vista, é igualmente válido afirmar que a defesa é que garante o contraditório, conquanto nele se manifeste ${ }^{453}$.

Cândido Rangel Dinamarco fala em dupla destinação do contraditório:

A garantia do contraditório, imposta pela Constituição com relação a todo e qualquer processo - civil, penal, trabalhista, ou mesmo nãojurisdicional (art. 5. ${ }^{\circ}$, inc. LV) -, significa em primeiro lugar que a lei deve instituir meios para a participação dos litigantes no processo e o juiz deve franquear-lhes esses meios. Mas significa também que o próprio juiz deve participar da preparação do julgamento a ser feito, exercendo ele próprio o contraditório. A garantia deste resolve-se, portanto, em um direito das partes e deveres do juiz. É do passado a afirmação do contraditório exclusivamente como abertura para as partes, desconsiderada a participação do juiz ${ }^{454}$.

É importante ressaltar que, no processo judicial, seja no civil, seja no penal, há a participação de no mínimo três elementos: o autor, que propõe a ação; o réu, que resiste à pretensão daquele; e, no centro, o juiz, que impulsiona e dirige o processo, bem como resolve a questão, decidindo a lide.

\footnotetext{
${ }^{452}$ MEIRELLES, 2012, p. 755.

453 GRINOVER, Ada Pellegrini. Novas tendências do direito processual de acordo com a Constituição de 1988. Rio de Janeiro: Forense Universitária, 1990, p. 4-5.

${ }^{454}$ DINAMARCO, Cândido Rangel. Fundamentos do processo civil moderno. 6. ed. São Paulo: Malheiros, 2010, t. I, p. 517.
} 
No processo administrativo disciplinar, a participação resume-se a dois integrantes: a Administração Pública, que acumula as atribuições de parte interessada e de juiz, e o servidor imputado, que se defende das acusações que lhe são feitas.

Ada Pellegrini Grinover ressalta que as garantias do contraditório e da ampla defesa desdobram-se hoje em três planos:

a) no plano jurisdicional, em que elas passam a ser expressamente reconhecidas, diretamente como tais, para o processo penal e para o nãopenal; b) no plano das acusações em geral, em que a garantia explicitamente abrange as pessoas objeto de acusação; c) no processo administrativo, sempre que haja litigantes ${ }^{455}$.

O direito ao contraditório significa o direito que tem uma parte de conhecer todos os dados, fatos, argumentos, documentos e as provas apresentadas pela outra parte e sobre eles poder manifestar-se e apresentar novas provas, com cujo teor ou interpretação possa reagir. Tal garantia também significa que a parte deverá participar, ou ser intimada a participar, da totalidade de provas que serão produzidas no decorrer do processo e da oitiva dos sujeitos.

Na lição de Antônio Carlos de Araújo Cintra, Ada Pellegrini Grinover e Cândido Rangel Dinamarco, o contraditório é constituído por dois elementos: a) informação; b) reação (esta, meramente possibilitada nos casos de direitos disponíveis) ${ }^{456}$.

Cândido Rangel Dinamarco afirma que a "efetividade no contraditório significa a real participação das pessoas no processo" ${ }^{457}$. Em seguida, expõe que o equilíbrio do contraditório traz a ideia de igualdade das partes. Tudo se faz para que haja uma igualdade de oportunidades das partes no processo.

Verifica-se que as partes no processo disciplinar são extremamente desiguais, dada a superioridade da Administração Pública em relação à capacidade de resistência processual do servidor acusado.

O Direito Processual Disciplinar mais atual tenta minimizar essa desigualdade entre as partes, justamente por intermédio do direito de defesa e do contraditório do servidor acusado.

Romeu Felipe Bacellar Filho põe em relevo a estrutura do contraditório: “A estrutura lógica do contraditório - bilateralidade do processo - aplicada ao processo

\footnotetext{
455 GRINOVER, 1991, p. 10.

456 CINTRA, Antônio Carlos de Araújo; GRINOVER, Ada Pellegrini; DINAMARCO, Cândido Rangel. Teoria geral do processo. 10. ed. São Paulo: Malheiros, 1994, p. 57.

${ }^{457}$ DINAMARCO, Cândido Rangel. O princípio do contraditório. Revista da Procuradoria Geral do Estado de São Paulo, São Paulo, n. 19, dez. 1981/dez. 1982, p. 33-36.
} 
administrativo disciplinar subordina o exercício da competência disciplinar a uma instância dialógica"458 . Para Romeu Felipe Bacellar Filho, "o contraditório visa equilibrar as 'forças' presentes em cada pólo da relação" ${ }^{459}$.

A garantia constitucional do contraditório no processo administrativo disciplinar ou na sindicância significa para o acusado ter ciência das provas juntadas aos autos e poder contestá-las de imediato, caso deseje, estabelecendo uma relação bilateral, não necessariamente antagônica, mas preferencialmente colaboradora com a elucidação da verdade.

Pode-se dizer que há contraditório apenas com a oferta, com a faculdade, com a prerrogativa que se concede ao interessado de produzir contradita em relação a atos que militem a seu desfavor, não caracterizando afronta ao princípio, se, uma vez devidamente ofertada a oportunidade à parte, ela se omite e não a exercita.

Em síntese, o contraditório materializa-se quando o processo propicia o diálogo. Daí a importância de se dar ciência ao acusado, como regra geral, com prazo hábil de antecedência de três dias úteis, de atos de produção de provas (diligências, perícias, testemunhos, etc.) e de decisões prolatadas, a fim de que a parte, caso queira, possa opor-se ou dar outra versão ou fornecer interpretação jurídica diversa.

Na lição de Romeu Felipe Bacellar Filho: “A efetividade do contraditório pode ser traduzida como reação necessária. Onde o contraditório é efetivo a defesa é sempre obrigatória. O diálogo é imposto, mesmo na omissão da parte acusada, em face da indisponibilidade do direito material" ${ }^{\prime 460}$.

Em razão disso, a Lei n. ${ }^{\circ}$ 8.112/90 estabeleceu a obrigatoriedade da defensoria dativa para o servidor revel, acusado no processo disciplinar.

Sem dúvida, concorda-se com Romeu Felipe Bacellar Filho quanto à importância do contraditório, mormente no cumprimento da competência sancionatória. Por isso, o contraditório deve ser efetivo tanto no processo disciplinar quanto na sindicância (sindicância processo) $^{461}$.

Assim, o contraditório deve ser estimulado de forma a ser efetivo e equilibrado. A atividade defensiva deve ser adequadamente desempenhada, com todos os meios e recursos necessários, para um processo justo.

\footnotetext{
${ }^{458}$ BACELLAR FILHO, Romeu Felipe. Processo administrativo disciplinar. 4 ed. São Paulo: Saraiva, 2013. p. 243.

${ }_{459}$ BACELLAR FILHO, 2013, p. 249.

${ }^{460}$ BACELLAR FILHO, 2013, p. 250.

${ }^{461}$ BACELLAR FILHO, 2013, p. 251.
} 
O contraditório, infraconstitucionalmente, está previsto nos artigos 153 e 156 da Lei n. ${ }^{\circ} 8.112$, de 11 de dezembro de 1990, mas também se encontra positivado no artigo 2. ${ }^{\circ}$, caput, da Lei n. ${ }^{\circ} 9.784$, de 29 de janeiro de 1999.

A ampla defesa permite à parte o direito de tudo conhecer e de tudo alegar em sua defesa; obviamente, essa amplitude tem as suas limitações nas possibilidades legais, mas não pode existir exceção.

No mesmo sentido, sobre a ampla defesa, Odete Medauar alerta:

A Constituição Federal de 1988 alude, não a simples direito de defesa, mas, sim, à ampla defesa. O preceito da ampla defesa reflete a evolução que reforça o princípio e denota elaboração acurada para melhor assegurar sua observância. Significa, então, que a possibilidade de rebater acusações, alegações, argumentos, interpretações de fatos, interpretações jurídicas, para evitar sanções ou prejuízos, não pode ser restrita, no contexto em que se realiza. Daí a expressão final do inciso LV, "com meios e recursos a ela inerentes", englobados na garantia, refletindo todos os seus desdobramentos, sem interpretação restritiva ${ }^{462}$.

É importante trazer à colação a enumeração realizada por Odete Medauar dos desdobramentos da ampla defesa, aplicados especificamente ao processo administrativo ${ }^{463}$ : o caráter prévio da defesa; o direito de interpor recurso administrativo; a defesa técnica; informação geral, como o direito de ser notificado e cientificado; o direito de solicitar a produção de provas, vê-las realizadas e consideradas.

No processo administrativo disciplinar, a garantia constitucional da ampla defesa oferece ao acusado, pessoalmente ou, a seu critério, por meio de procurador, certos direitos gratuitos, respeitados pela administração: ser notificado da existência do processo (verdadeira cláusula inicial da ampla defesa, pois ninguém pode defender-se se não souber que existe, contra si, uma acusação); ter acesso aos autos; participar da formação de provas e vê-las apreciadas; ter a faculdade de manifestar-se por último; ter defesa escrita analisada antes da decisão; ser alvo de julgamento fundamentado e motivado e dele ter ciência (précondição para poder exercer o direito de recorrer).

Como consequência da ampla defesa, há a presunção de inocência do servidor até o julgamento do processo, com o ônus de provar a responsabilização a cargo da administração.

A ampla defesa, infraconstitucionalmente, está prevista nos artigos 116, parágrafo único, 143, 153 e 156 da Lei n. ${ }^{\circ} 8.112$, de 11 de dezembro de 1990; também se encontra no artigo 2. ${ }^{\circ}$, caput e parágrafo único, X, da Lei n. ${ }^{\circ}$ 9.784, de 29 de janeiro de 1999.

\footnotetext{
${ }^{462}$ MEDAUAR, 1993, p. 112, grifo da autora.

${ }^{463}$ MEDAUAR, 1993, p. 115-119.
} 
Romeu Felipe Bacellar Filho defende que:

"a idéia subjacente ao direito à ampla defesa é a de que, somente através do processo o Estado-Administração pode exercitar a competência disciplinar - não há sanção administrativa sem processo - porque a condenação só é legítima quando resulta de um processo válido. Antes de cumprido o iter processual, o servidor acusado é considerado presumivelmente inocente. Nesta medida, o princípio da presunção de inocência é inerente ao direito à ampla defesa, decorrência lógica do sistema processual contraditório, onde a decisão substancia a síntese da contraposição entre tese e antítese, desempenhadas por sujeitos processuais autônomos"

Como desdobramentos da ampla defesa no processo administrativo, as partes têm direito a serem ouvidas, a apresentar razões de convencimento, a produzir provas, a repelir provas oferecidas pela Administração, a acompanhar o processo e a ter ciência prévia do desenvolvimento das várias fases, a indicar e a ouvir testemunhas.

Ocorre que nem sempre foi assim. Antes da Constituição Federal de 1988, a realidade era outra. A ampla defesa consagrou inúmeros direitos, que eram negados pela Administração ao servidor acusado.

Ana Maria Rodrigues Barata, com muita propriedade, lembra:

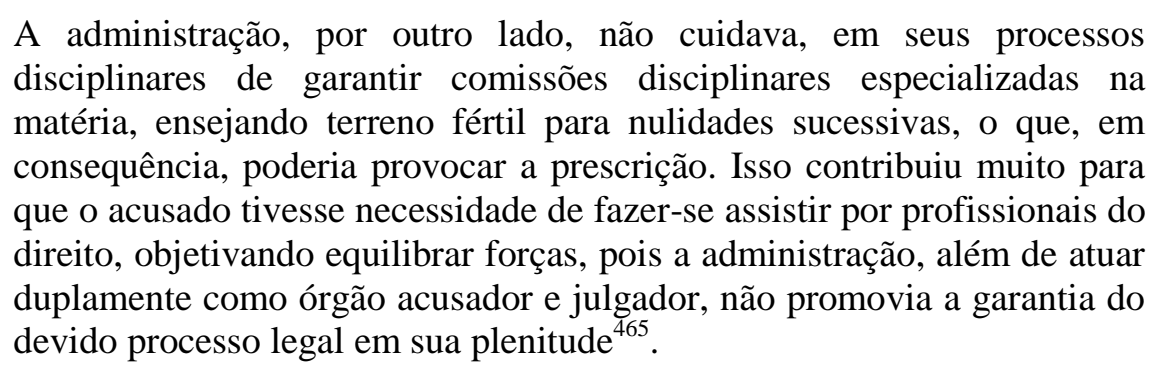

O artigo 133 da Constituição Federal estabelece que o advogado é indispensável à administração da Justiça.

Diante da sonegação de garantias aos acusados, da pouca formação das comissões disciplinares, o que conduzia a nulidades nos processos disciplinares, o Superior Tribunal de Justiça emitiu a Súmula n. 343 com a seguinte redação abrangendo os processos administrativos disciplinares: "É obrigatória a presença de advogado em todas as fases do processo administrativo disciplinar".

${ }^{464}$ BACELLAR FILHO, Romeu Felipe. Princípios constitucionais do processo administrativo disciplinar. São Paulo: Max Limonad, 1998, p. 271.

${ }^{465}$ BARATA, 2008, p. 63. 
Na interpretação de Ana Maria Rodrigues Barata, diante das decisões do Superior Tribunal de Justiça, a Súmula só seria aplicada aos casos de faltas graves puníveis com demissão. A autora, porém, ressalta:

Entretanto, a Súmula vinha sendo aplicada em qualquer hipótese, mesmo
para o acusado que detinha conhecimentos jurídicos, anulando processos
disciplinares que estavam sem acompanhamento por advogado. Muitos
desses processos apresentavam-se bem estruturados, sem qualquer
ilegalidade, porém o acusado não estava acompanhado de advogado, o
que impunha a anulação do processo. Por isso, ocorreu a reintegração de
uma massa enorme de servidores, alguns reconhecidamente culpados pela
prática de infrações graves. Havia, ainda, grandes possibilidades do poder
público não poder mais instaurar novo processo, pois o poder disciplinar
já estava fulminado pela prescrição, em razão da demora na prestação
jurisdicional ${ }^{466}$.

O Supremo Tribunal Federal decidiu várias vezes que a atuação do advogado em processo disciplinar não era obrigatória, conforme o disposto na Lei n. ${ }^{\circ}$ 8.112/90 e na Constituição Federal; só se torna obrigatória em processos judiciais, de acordo com o artigo 133 da Constituição Federal ${ }^{467}$.

Diante de tal realidade, o Instituto Nacional do Seguro Social (INSS) ingressou no Supremo Tribunal Federal com um recurso extraordinário (RE n. ${ }^{\circ}$ 434.059-3, com relatoria do Ministro Gilmar Mendes) contra a decisão do Superior Tribunal de Justiça que aplicou a sua Súmula n. ${ }^{\circ}$ 343. O Supremo Tribunal Federal reformou a decisão do Superior Tribunal de Justiça, votando a Súmula Vinculante n. ${ }^{\circ}$ 5, de 16 de maio de 2008: "A falta de defesa técnica por advogado em processo administrativo disciplinar não ofende a Constituição".

${ }^{466}$ BARATA, 2008, p. 65-66.

${ }^{467}$ STF, Agravo de Instrumento n. ${ }^{\circ}$ 207.197: "Ementa: A extensão da garantia constitucional do contraditório (art. 5. ${ }^{\circ}, \mathrm{LV}$ ) aos procedimentos administrativos não tem o significado de subordinar a estes toda a normatividade referente aos feitos judiciais, onde é indispensável a atuação do advogado". STF, Agravo de Instrumento n. ${ }^{\circ}$ 239.029, decisão: “[...] Quanto à defesa, a Corte de origem deixou assentado haver sido dada oportunidade, no processo administrativo, para o Agravante defender-se. Descabe, no caso, ter como indispensável a presença de profissional da advocacia, isso ante a natureza do processo - simplesmente administrativo". STF, Recurso Extraordinário n. ${ }^{\circ}$ 244.027: "Ementa: Agravo regimental a que se nega provimento, porquanto não trouxe o agravante argumentos suficientes a infirmar os precedentes citados na decisão impugnada, no sentido de que, uma vez dada a oportunidade ao agravante de se defender, inclusive de oferecer pedido de reconsideração, descabe falar em ofensa aos princípios da ampla defesa e do contraditório no fato de se considerar dispensável, no processo administrativo, a presença de advogado, cuja atuação, no âmbito judicial, é obrigatória". STF, Recurso Extraordinário n. ${ }^{\circ}$ 396.288: "Ementa: [...] 2. No processo administrativo, é admissível a defesa pelo próprio acusado ou por advogado regularmente constituído, de modo que a ausência do advogado no feito administrativo não tem o condão de fulminar de nulidade o procedimento e a decisão correspondente". STF, Mandado de Segurança n. ${ }^{\circ}$ 22.962, despacho: “[...] Outrossim, a alegada ofensa ao art. 156 da Lei n. ${ }^{\circ} 8.112 / 90$ não ocorre. A Lei apenas faculta que o servidor acompanhe o processo pessoalmente ou por intermédio de procurador, inclusive na fase instrutória. Consoante se observa dos documentos constantes de fls. 64/70, o servidor foi cientificado de todos os procedimentos instrutórios promovidos pela Comissão. O princípio do devido processo legal foi observado, assim como a determinação do art. 156 da Lei n. ${ }^{\circ}$ 8.112/90. [...] O princípio do devido processo legal e os dispositivos da Lei n. ${ }^{\circ} 8.112 / 90$ foram respeitados". 
Os ministros do Supremo Tribunal Federal determinaram que, em processo administrativo disciplinar (PAD), a presença de advogado não é obrigatória. Trata-se de uma faculdade que, em âmbito federal, está expressa no artigo 156 da Lei n. ${ }^{\circ}$ 8.112/90. Assim, a ausência de defesa técnica por advogado não implica nulidade do processo administrativo disciplinar.

No entender do Supremo Tribunal Federal, o importante, para o exercício da ampla defesa, é garantir o direito à informação, à manifestação e à consideração dos argumentos manifestados pelo indiciado.

Defesa técnica é a peça elaborada em processo administrativo disciplinar, em virtude de uma acusação formal pela prática de infração administrativa, por intermédio de um profissional técnico, principalmente para faltas graves. A defesa técnica é exigida para o indiciado revel que, regularmente citado, não apresenta defesa no prazo legal, hipótese em que a autoridade instauradora do processo designará servidor como defensor dativo, que deverá ser ocupante de cargo efetivo superior ou de mesmo nível, ou ter nível de escolaridade igual ou superior ao do indiciado (artigo 164, e parágrafos, da Lei n. ${ }^{\circ}$ $8.112 / 90)$.

Como bem lembra Ana Maria Rodrigues Barata:

Algumas vezes é o próprio acusado, embora notificado, quem se omite no
exercício de todas essas garantias, exatamente para ver seu processo
anulado no âmbito judicial, com forte tendência para beneficiar-se com a
prescrição, pois já percebeu que esse é um caminho demorado e, em
consequência, mais vantajoso, também, porque, ao ser reintegrado,
receberá a remuneração retroativa sem ter trabalhado ${ }^{468}$.

Discute-se a possibilidade de garantia da ampla defesa por meio de defensor dativo que não seja advogado, questiona-se se ela seria assegurada tão somente em uma defesa técnica feita por um advogado.

Em favor do cancelamento da Súmula, posicionaram-se: José Armando da Costa ${ }^{469}$, Marco Antônio Praxedes de Moraes Filho ${ }^{470}$ e Romeu Felipe Bacellar Filho ${ }^{471}$.

\footnotetext{
${ }^{468}$ BARATA, 2008, p. 66.

${ }^{469}$ COSTA, 2010, p. 249-250.

${ }^{470}$ MORAES FILHO, Marco Antônio Praxedes de. Súmula Vinculante n. 5 do Supremo Tribunal Federal e o sistema processual administrativo punitivo: um retrospecto na interpretação contemporânea do princípio do devido processo legal e na evolução dos desdobramentos do princípio da ampla defesa. In: NOHARA, Irene Patrícia; MORAES FILHO, Marco Antônio Praxedes de (Org.). Processo administrativo: temas polêmicos da Lei n. ${ }^{\circ}$ 9.784/00. São Paulo: Atlas, 2011. p. 158-183.

${ }^{471} \mathrm{Na}$ visão de Romeu Felipe Bacellar Filho, a Súmula Vinculante n. ${ }^{\circ} 5$ ostenta graves vícios materiais de inconstitucionalidade, além de vícios formais, analisados na proposta de cancelamento ajuizada pelo Conselho Federal da Ordem dos Advogados do Brasil (OAB), visto que a defesa técnica constitui inobjetável exigência do direito fundamental à ampla defesa no processo administrativo disciplinar (BACELLAR FILHO, 2013, p. 318-345).
} 
Concorda-se com Ana Maria Barata, para quem as duas súmulas necessitam de uma melhor redação. Em relação à Súmula n. ${ }^{\circ} 343$ do STJ, não cabe mais discussão, em razão de sua revogação pela Súmula Vinculante n. ${ }^{\circ}$. O que se deve fazer é procurar dar harmonia à atual Súmula:

Atente-se para o fato de que a Súmula $n^{\circ} 5$ não proibiu que a defesa técnica por profissional do direito seja garantida pela Administração, ela apenas especificou que não é obrigatória a presença do advogado no processo administrativo disciplinar (PAD), podendo essa defesa ser efetivada pelo indiciado ou mesmo por outro profissional da área do direito, inclusive o advogado ${ }^{472}$.

Basta lembrar que, no âmbito trabalhista e nos juizados especiais, em alguns casos, não há obrigatoriedade do advogado. Nem por isso todos são prejudicados nas ações. $\mathrm{O}$ mesmo deve ser aplicado ao processo administrativo disciplinar.

A leitura de Ana Maria Rodrigues Barata sobre a Súmula Vinculante n. ${ }^{\circ}$, com a qual se concorda, é a seguinte:

Para os casos de faltas graves que importem em demissão de servidores que não detenham conhecimento jurídico ou que não possam pagar honorários de profissionais do direito para o exercício de sua ampla defesa em processo administrativo disciplinar, a administração deve providenciar profissional da área jurídica para atuar na ampla defesa ou na defesa técnica, designando servidor com conhecimento na área jurídica, ou requisitar servidor de outro órgão ou de órgão de classe a que pertencer o acusado, para esse mister ${ }^{473}$.

Cada caso é um caso, deve-se destacar que a situação precisa ser verificada concretamente no processo, como um corolário do princípio do prejuízo (ter sido prejudicada a defesa, em decorrência da incapacidade de o servidor defender-se em virtude da complexidade do caso concreto). Não se pode adotar de imediato uma presunção de nulidade, conforme sumulara o Superior Tribunal de Justiça.

Todavia, pode acontecer de o indiciado apresentar uma defesa escrita tão ruim, que será como se ele estivesse indefeso. Às vezes, mesmo a defesa apresentada por advogado é tão fraca que a Administração não pode fingir que o acusado se defendeu, pois a defesa precisa ser efetiva, ainda que apenas no final do processo. Portanto, se acontecer de a defesa escrita apresentada pelo acusado ou por seu defensor ser muito fraca, a Administração terá que considerá-lo revel e nomear para ele um defensor dativo. Entendo que foi nesse sentido que, nos debates entre os Ministros do STF, no julgamento do RE 434059 que deu origem à Súmula vinculante $\mathrm{n}^{\circ}$, 5 , se levantou a questão de que, na eventualidade de "o processo ser muito complexo e fugir à compreensão do servidor para que ele próprio se defenda", seria necessária a nomeação, pela própria Administração, de um defensor que melhor exerça este mister. O

${ }^{472}$ BARATA, 2008, p. 67, grifos da autora.

${ }^{473}$ BARATA, 2008, p. 68. 
Supremo Tribunal Federal não parece ter criado uma exceção à sua própria súmula. O que se lembrou foi apenas o fato de que não é apenas quando o servidor não apresenta a defesa escrita que ele precisará de um defensor fornecido pela própria Administração, mas também quando se considerar, no caso concreto, que a sua defesa escrita está prejudicada, tendo em vista que a complexidade da matéria não lhe permite efetuar sua própria defesa ${ }^{474}$.

Edmir Netto de Araújo chama a atenção para o fato de a Súmula Vinculante n. ${ }^{\circ} 5$ dizer que a defesa técnica por advogado não é obrigatória, ou seja, a falta de advogado não ofende a Constituição. Mas ele indaga: se a lei o exigir, não é nulidade processual? Deixaria de ser exigível, ou deixaria de ser ilegal? O referido autor tem razão e explica:

Não ofender a Constituição, entretanto, não significa que as leis (federal, estadual, distrital, municipal) sobre processo administrativo em geral ou disciplinar em especial não possam prever a obrigatoriedade de defesa técnica por advogado para indiciados, constituindo portanto caso de nulidade do feito, por ilegalidade, sua não observância, embora não inconstitucional, pois se não ofende a Carta Magna terá sido ofendida lei específica a respeito ${ }^{475}$.

Edmir Netto de Araújo justifica seu entendimento citando o exemplo do município de São Paulo (Lei n. ${ }^{\circ}$ 8.989/79, artigo 212 e parágrafo único) e do Estado de São Paulo (Lei n. ${ }^{\circ}$ 10261/68, com redação dada pela Lei Complementar n. ${ }^{\circ}$ 942/2003, artigo 278, caput e $\S 1$. $^{\circ}$, item 4, artigo 282, caput e $\S 3 .^{\circ}$; artigo 292, parágrafo único), nos quais a interpretação da referida Súmula Vinculante tem sido nesse sentido, como aliás já havia sido sumulado pelo Superior Tribunal de Justiça desde 21 de setembro de 2007 (Súmula n. 343$)$.

Assim, a Súmula Vinculante n. ${ }^{\circ} 5$ do Supremo Tribunal Federal deve ser adequada ao caso concreto. Caberá à Administração, diante da situação concreta, avaliar a necessidade ou não de profissional da área jurídica. O que se deve resguardar é o sagrado direito do acusado ao devido processo legal, à ampla defesa e ao contraditório.

Acertadamente, José Armando da Costa afirma:

O que dimensiona o alcance da defesa não é a natureza do procedimento respectivo. E sim a substância das acusações. Pode-se concluir, com outras palavras, que o limite da defesa é o tamanho das acusações. Se a imputação assestada ao servidor constitui falta leve, a ele se deverá deferir oportunidade para se defender de tal acusação. Caso seja ele verdadeiramente culpado, não poderá, logicamente, comprovar o contrário, devendo, por via de consequência, ser apenado. Já que o direito de defesa não configura licença para assegurar impunidade. O injurídico é

\footnotetext{
${ }^{474}$ MADEIRA, 2008, p. 158-159.
}

${ }^{475}$ ARAÚJO, 2014, p. 998. 
ato de negação da oportunidade do largo e adequado exercício da defesa $^{476}$.

Não importa se se trata de processo administrativo disciplinar ou de sindicância. Em todos os procedimentos disciplinares, o esforço amplo da defesa não fica contido nos limites de uma peça escrita, abrangendo, para José Armando da Costa, em um rol exemplificativo, os seguintes aspectos:

a) oportunidade para prestar esclarecimentos sobre a imputação e os respectivos fatos geradores;

b) possibilidade para arguir suspeições e impedimentos;

c) apresentação de razões por escrito;

d) franquia aos locais de trabalho da comissão, a fim de poder o acusado, pessoalmente ou por intermédio de procurador constituído, inquirir, reinquirir e contraditar testemunhas, devendo, para tanto, ser devidamente notificado a respeito da realização dessas audiências, com a especificação do local, dia e horário;

e) oportunidade para requerer todas as provas em direito acatadas e arrolar testemunhas;

f) possibilidade de ter o acusado vista sobre os pedidos de exames periciais formalizados pela comissão de processo, podendo, no interesse de sua defesa, acrescentar quesitos;

g) ensejo para arguir prescrição ${ }^{477}$.

Com muita propriedade, conclui José Armando da Costa sobre o direito de defesa: "Constata-se, assim, que o amplo direito de defesa tem função predominantemente pública, sendo, portanto, indispensável à lídima repressão disciplinar por mais branda que seja a punição. Constituindo, ainda, garantia constitucional irrenunciável do servidor acusado" ${ }^{478}$.

A comissão deve ter como bandeira que as garantias da ampla defesa e do contraditório são a base da condução do processo, pois são os pilares da validade dos atos processuais, da decisão prolatada e de todo o processo em si, independentemente do rito (se processo administrativo disciplinar em rito ordinário ou sumário, ou se sindicância), sob pena de nulidade.

Todos os meios de apuração de faltas admitidos (processo administrativo disciplinar, sindicância, processo sumário) devem estar cercados de todas as garantias processuais constitucionais, principalmente do devido processo legal, da ampla defesa e do contraditório, de forma a permitir a correta aplicação de sanções ou a absolvição dos acusados. Essas garantias devem abranger os acusados em geral, logo, estão incluídos os servidores públicos temporários.

\footnotetext{
${ }^{476}$ COSTA, 2010, p. 118.

${ }^{477}$ COSTA, 2010, p. 119.

${ }^{478}$ COSTA, 2010, p. 116.
} 


\subsection{PENALIDADES}

Ao cometer uma infração disciplinar, o servidor público será submetido a um processo administrativo disciplinar, a uma sindicância ou a um processo sumário (dependendo do caso) para apurar a falta cometida, observado o devido processo legal, o contraditório e a ampla defesa. Em sendo comprovada a falta, o servidor público será sancionado, de acordo com a gravidade da situação. Haverá uma penalidade a ser aplicada ao servidor público.

Sanção disciplinar é a punição imposta ao funcionário público que cometeu alguma infração de natureza funcional ou cujo comportamento na vida privada repercuta de forma a pôr em jogo o prestígio do órgão público em que serve ${ }^{479}$.

Regis Fernandes de Oliveira, sobre penalidade, expõe o seguinte pensamento: "A penalidade é, pois, a consequência da rejeição que a ordem jurídica prevê ao comportamento contrário àquele previsto na norma. Evidente está que a lei escalona as sanções de acordo com a gravidade que a lesão causa ao ordenamento" ${ }^{\text {"480 }}$.

Carlos Borges de Castro ensina:

Há faltas disciplinares que não determinam a extinção do vínculo. Estamos falando das infrações catalogadas como atos faltosos e que são apenadas com advertência ou repreensão e suspensão. O ato faltoso é, assim, uma violação contratual ou estatutária menos grave e que não aconselha a medida extrema. A CLT estabelece o limite máximo da suspensão disciplinar do empregado: trinta dias. Acima desse limite, a suspensão "[...] importa em rescisão injusta do contrato de trabalho" (art. 474). No que respeita ao funcionário público, as sanções disciplinares são maiores e graduadas segundo a natureza e a gravidade da infração ${ }^{481}$.

A sanção disciplinar tem duas funções: preventiva (a sanção prevista é uma ameaça, uma cominação, fazendo com que o servidor se acautele para não transgredir nenhuma norma disciplinar) e repressiva (já tendo infringido a norma, sofre o servidor faltoso, em concreto, a reprimenda administrativa).

Preventiva ou repressiva, a sanção disciplinar tem por objetivo fundamental a desenvoltura normal e regular do serviço público. Também se predestina a resguardar o prestígio da administração pública perante a coletividade beneficiária dos seus serviços.

${ }^{479}$ COSTA, José Armando da. Direito administrativo disciplinar. 2. ed. Rio de Janeiro: Forense; São Paulo: Método, 2009, p. 199.

${ }^{480}$ OLIVEIRA, 2008, p. 147.

${ }^{481}$ CASTRO, 1981, p. 172. 
Com exceção das sanções de natureza expulsiva, colimam as sanções disciplinares, por outro lado, a educação ou a reeducação do punido $^{482}$.

A exemplaridade também poderia ser incluída nos objetivos da punição disciplinar, pois a pena imposta ao servidor faltoso, além de atingi-lo, reflete-se no seio do funcionalismo a que pertence o punido. Mas é importante ter cautela, pois tal objetivo somente surtirá efeito se a apenação tiver sido imposta com critério e justiça, sob pena de provocar revolta no seio da repartição.

As penalidades são classificadas ${ }^{483}$ de acordo com o gênero e a espécie. As penalidades administrativas em gênero classificam-se, quanto à natureza, em morais ${ }^{484}$, pecuniárias $^{485}, \operatorname{mistas}^{486}$ e profissionais ${ }^{487}$; quanto à finalidade, em $\operatorname{corretivas}^{488}$, expulsivas $^{489}$ e revocatórias ${ }^{490}$.

As penalidades administrativas em espécie são: advertência; suspensão; multa ${ }^{491}$; destituição de função comissionada ou de cargo em comissão; cassação de aposentadoria ou disponibilidade; demissão.

A Lei n. ${ }^{\circ} 8.112 / 90$, em seu artigo 127, enumera as seguintes penas administrativas: advertência, suspensão, demissão, cassação de aposentadoria ou de disponibilidade; destituição de cargo em comissão ou de função comissionada ${ }^{492}$.

Por força do artigo 5. ${ }^{\circ}$, inciso XXXIX, da Constituição Federal, está consagrado o princípio da prévia cominação legal, não se admitindo no processo administrativo disciplinar outras penas.

${ }^{482}$ COSTA, 2009, p. 200-201.

${ }^{483}$ ARAÚJO, 2014, p. 1026.

${ }^{484}$ As penalidades administrativas morais, como a advertência, afetam o servidor no seu brio e amor-próprio ou na sua honra e reputação.

${ }_{485}$ As pecuniárias, como a multa, golpeiam as finanças do infrator.

${ }^{486}$ As mistas, como a suspensão, associam os aspectos negativos das penas morais (foro íntimo) e das penas pecuniárias (patrimônio).

${ }^{487}$ As profissionais castigam o funcionário em função de sua carreira ou situação, como a remoção de um lugar para outro ou a transferência para outro cargo ou serviço. A pena de destituição de função pode ser incluída nessa classe das profissionais.

${ }^{488}$ As corretivas objetivam a recuperação do servidor faltoso. São exemplo dessa classe: as penas de advertência, multa, suspensão e prisão.

${ }^{489}$ As expulsivas, como a demissão, têm por fim a eliminação do servidor dos quadros do órgão público.

${ }^{490}$ As revocatórias, como a cassação de aposentadoria ou disponibilidade, alcançam o faltoso já na situação de inatividade.

${ }^{491}$ Essa sanção é de natureza pecuniária e constitui a obrigação imposta ao servidor de pagar ao Estado uma certa quantia em dinheiro. $O$ desconto é feito em folha, não podendo ultrapassar a metade do estipêndio.

${ }^{492}$ A pena de destituição de função comissionada, apesar de estar no rol do artigo 127 da Lei n. ${ }^{\circ} 8.112 / 90$, restou inaplicável, pois a Lei, nos artigos seguintes, não enumerou as hipóteses de sua aplicação. Em atenção ao devido processo legal, exige-se não só a previsão da pena, mas também o estabelecimento de suas hipóteses de aplicação (TEIXEIRA, 2014, p. 1049). 
Além disso, a Lei n. ${ }^{\circ}$ 8.112/90 vincula uma única pena a cada infração. Configurado o ilícito, a pena é vinculada, não há espaço para discricionariedade. Não se pode dizer que a autoridade tem o poder de perdoar, compor, transigir ou aplicar pena alternativa.

A penalidade de advertência é considerada uma sanção branda, seria equiparada a um alerta ou a um sinal amarelo de trânsito.

Marcos Salles Teixeira, ao tratar da responsabilidade penal, esclarece:

Descrita pelo art. 129 da Lei $\mathrm{n}^{\circ} 8.112$, de 11/12/90, a advertência é pena de menor gravidade e de menor repercussão no trabalho. Em geral, resulta de condutas comportamentais associadas a valores básicos para o funcionamento da Administração, tais como zelo, dedicação, lealdade, hierarquia, discrição, presteza, assiduidade, pontualidade, urbanidade, desde que não sejam reincidentes ${ }^{493}$.

José Armando da Costa chega a dizer sobre a advertência: "É a sanção disciplinar mais branda do nosso direito, a qual, constituindo uma admoestação apenas verbal, não chega sequer a sujar a folha de assentamentos individuais do servidor transgressor" ${ }^{\natural 94}$.

Cabe a aplicação de advertência nas hipóteses de descumprimento de qualquer dos deveres funcionais listados no artigo 116 da Lei n. ${ }^{\circ}$ 8.112/90 e de afronta a proibições do artigo 117, I a VIII e XIX. A advertência não comporta gradação.

Da análise conjunta dos artigos 129 e 116 da Lei n. ${ }^{\circ}$ 8.112/90, depreende-se que a lista de deveres funcionais não se encerra no segundo, pois, além de outras leis que porventura existam impondo deveres a servidor, pode haver, em cada órgão da administração, deveres funcionais internamente regulados na normatização infralegal.

Em relação ao procedimento de aplicação da penalidade de advertência, pode-se dizer que, geralmente, a advertência é aplicada por escrito, por meio de uma portaria expedida pela autoridade competente, com o devido registro da penalidade nos assentamentos funcionais do servidor, que toma ciência da punição ao final do processo ou pela publicação no Diário Oficial da União (DOU), caso tenha sido ato ministerial. É importante ressaltar que não há advertência verbal ${ }^{495}$.

A penalidade de suspensão é aplicada nas hipóteses em que há reincidência das faltas puníveis com advertência e no caso de faltas de maior intensidade, por desrespeito a

\footnotetext{
493 TEIXEIRA, 2014, p. 1054.

${ }^{494}$ COSTA, 2009, p. 204.

495 Marcos Salles Teixeira afirma quanto à aplicação de advertência aos inativos o seguinte: "Na hipótese de processo aberto contra inativo concluir pelo cometimento de ilícito que seria punido com advertência, diante da impossibilidade de aplicação, apenas registra-se o fato apurado nos assentamentos funcionais do exservidor" (TEIXEIRA, 2014, p. 1056).
} 
deveres e proibições, reveladoras de desvio de comportamento grave, que, todavia, não implicam demissão (artigo 130 da Lei n. ${ }^{\circ}$ 8.112/90). Na lição de José Armando da Costa: "É o afastamento do cargo imposto ao servidor faltoso, por certo período de tempo (não podendo ultrapassar 90 dias), com perda do vencimento correspondente aos dias do afastamento, e outros prejuízos que se refletem na contagem do tempo de serviço do

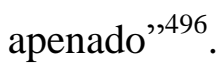

Marcos Salles Teixeira, com muita propriedade, observa:

Excluindo-se a hipótese de injustificada recusa de submissão à inspeção médica (para a qual o art. 130, § $1 .^{\circ}$, da Lei n..$^{\circ} 8.112$, de 11/12/90, impõe expressamente pena de suspensão de até quinze dias), a aplicação originária da suspensão na citada Lei é de caráter residual, ou seja, a Lei não estabelece, de forma expressa e enumerada, a que irregularidades ela se impõe.Nas listas de infrações dos arts. 116, 117 e 132, descartando-se as hipóteses expressas de aplicação originária de advertência (qualquer inciso do art. 116 e incisos I a VIII e XIX do art.117) e de aplicação de pena capital (incisos IX a XVI do art. 117 e art. 132), por exclusão, restam originalmente puníveis com suspensão apenas os incisos XVII e XVIII do art. 117, todos da Lei n. ${ }^{\circ} 8.112$, de $11 / 12 / 90^{497}$.

A demissão, a cassação de aposentadoria e a cassação de disponibilidade têm um ponto em comum: as três possuem as mesmas hipóteses de aplicação, o que vai diferenciar é o polo passivo. No caso da demissão, trata-se de servidor ativo de cargo efetivo; já a cassação de aposentadoria e a cassação de disponibilidade referem-se ao servidor inativo. Essas penalidades dizem respeito às violações das proibições constantes dos incisos IX a XVI do artigo 117 e de todos os incisos do artigo 132, ambos da Lei n. ${ }^{\circ}$ 8.112/90, sem comportar gradação.

Os requisitos para a aplicação da penalidade de demissão são: o servidor que comete infração grave deve estar no exercício de cargo efetivo e encontrar-se na ativa quando da apuração e da apenação. Marcos Salles Teixeira esclarece sobre a demissão o seguinte:

Alguns fatos ensejadores de demissão estão descritos no próprio artigo
132 , junto à previsão da pena, enquanto outros fatos estão descritos nos
incisos IX a XVI do art. 117 e nos arts. 133,138 e 139 , todos da Lei n.
(o
todis, de $11 / 12 / 90$. Independentemente do fato ensejador, tem-se que
todas hipóteses de aplicação de demissão estão exaustivamente listadas
no art. 132 da Lei n. ${ }^{\circ} 8.112$, de $11 / 12 / 90$. Com isto, mesmo nos casos de
fatos enquadrados nos incisos IX a XVI do art. 117 ou nos arts. 133,138
e 139 da Lei n. ${ }^{\circ} 8.112$, de $11 / 12 / 90$, deve atentar a autoridade julgadora
para a necessidade de embasar o ato de demissão nos incisos XIII, XII, II
e III do art. 132 da norma (aqueles primeiros dispositivos apenas

${ }^{496}$ COSTA, 2009, p. 204.

${ }^{497}$ TEIXEIRA, 2014, p. 1056. 
descrevem fatos, sendo necessária a capitulação nestes últimos para se aplicar a pena $)^{498}$.

O nível de gravidade da infração apenada com demissão é tão alto que José Armando da Costa chega a dizer: "Pena expulsiva que consiste na demissão, na exclusão forçada, do servidor do cargo público que ocupava. É a mais rigorosa das sanções disciplinares. Daí porque somente é aplicada no caso de faltas dotadas de elevado teor de gravidade [...]",499.

A Administração Pública deve apurar a infração cometida pelo servidor na ativa (quando legalmente investido no cargo, em seu pleno exercício), mesmo que o referido servidor já esteja aposentado ou em disponibilidade. Isso significa que não interessa a condição do servidor à época da apuração, a Administração Pública é obrigada a apurar os fatos. É em razão disso que foram incluídas as penas estatutárias de cassação de aposentadoria e da cassação de disponibilidade.

A aposentadoria ${ }^{500}$ e a disponibilidade ${ }^{501}$ são espécies de inatividade.

Nas situações que envolvam cassação de aposentadoria ou de disponibilidade, o ato punitivo deve combinar o artigo 134 com o enquadramento do fato cometido na ativa (incisos IX a XVI do artigo 117 ou I a XII do artigo 132, todos da Lei n. ${ }^{\circ}$ 8.112/90).

A cassação de aposentadoria é a pena disciplinar imposta aos servidores inativos que hajam, na atividade, cometido transgressões puníveis com demissão.

A disponibilidade é a sanção aplicável ao servidor que deixa de assumir no prazo legal a função em que for aproveitado, ou que tenha transgredido alguma norma a que fica sujeito, mesmo na inatividade.

Aplica-se a pena de destituição de cargo em comissão ao servidor que ocupa apenas um cargo de confiança ${ }^{502}$. Ocorre que o legislador, no artigo 135 da Lei n. ${ }^{\circ}$

\footnotetext{
498 TEIXEIRA, 2014, p. 1067.

${ }^{499}$ COSTA, 2009, p. 205.

500 A aposentadoria é um benefício obtido nos seguintes casos: invalidez permanente ou de parâmetro temporal (compulsoriamente ou a pedido), conforme o artigo 186 da Lei n. ${ }^{\circ} 8.112 / 90$. A Lei n. ${ }^{\circ} 8.112 / 90$ não impôs restrição para a natureza da aposentadoria a ser cassada, podendo, então, a pena ser aplicada inclusive em caso de aposentadoria por invalidez. Tampouco importa, para a posterior responsabilização, que, à época do fato, o servidor já tenha tempo para aposentar-se voluntariamente. A perda da aposentadoria de servidor não impede que o apenado leve o tempo de contribuição previdenciária para o regime geral de aposentadoria. Da mesma forma, se a aposentadoria deu-se por invalidez, não traz prejuízo alegar-se a mesma cláusula no regime geral. Por fim, encontra-se superada a alegação de inconstitucionalidade da pena (STF, Recurso em Mandado de Segurança n. ${ }^{\circ}$ 24.557; STF, Mandado de Segurança n. ${ }^{\circ}$ 21.948; STF, Mandado de Segurança n. ${ }^{\circ}$ 23.299) (TEIXEIRA, 2014, p. 1067-1068).

${ }^{501}$ De conformidade com o artigo $37, \S \S 3 .^{\circ}$ e $4 .^{\circ}$, da Lei n. ${ }^{\circ} 8.112 / 90$, a disponibilidade é aplicada ao servidor nos casos de reorganização ou de extinção de seu órgão, de extinção de seu cargo ou de declaração de sua desnecessidade, até que o servidor seja aproveitado em outra vaga.

${ }^{502}$ Que não tem cargo efetivo.
} 
8.112/90, quer que a aplicação da pena expulsiva desse servidor sem vínculo efetivo tenha uma maior abrangência que a aplicação da pena expulsiva do servidor efetivo.

Sobre a destituição do cargo em comissão, são válidos os ensinamentos de José Armando da Costa:

É a perda do cargo comissionado imposta a quem exerça função de confiança, por falta de exação no cumprimento dos respectivos deveres. Tal reprimenda disciplinar é imposta nos casos que sujeitam o infrator às penalidades de suspensão e de demissão, quando não se trate de função exercida por ocupante de cargo efetivo (art. 135 da Lei n. $\left.{ }^{\circ} 8.112 / 90\right)$ ). Tal punição, quando se trate de infringência do art. 117, incisos IX e XI, acarreta a indisponibilidade dos bens e a incompatibilidade, temporária ou definitiva, do ex-servidor para nova investidura em cargo público, nos termos do art. 137 e seu parágrafo único, todos do Regime Jurídico Federal $^{503}$.

Assim, a pena de destituição de cargo em comissão engloba os casos de infração sujeita às penalidades de suspensão e de demissão ${ }^{504}$.

Quanto à competência para a aplicação das penas, como regra geral, válida para toda a administração pública federal, a Lei n. ${ }^{\circ}$ 8.112/90 estabelece a competência para a aplicação das penas disciplinares:

Art. 141. As penalidades disciplinares serão aplicadas:

I - pelo Presidente da República, pelos Presidentes das Casas do Poder Legislativo e dos Tribunais Federais e pelo Procurador-Geral da República, quando se tratar de demissão e cassação de aposentadoria ou disponibilidade de servidor vinculado ao respectivo Poder, órgão, ou entidade;

II - pelas autoridades administrativas de hierarquia imediatamente inferior àquelas mencionadas no inciso anterior, quando se tratar de suspensão superior a 30 (trinta) dias;

III - pelo chefe da repartição e outras autoridades na forma dos respectivos regimentos ou regulamentos, nos casos de advertência ou de suspensão de até 30 (trinta) dias;

IV - pela autoridade que houver feito a nomeação, quando se tratar de destituição de cargo em comissão.

Todavia, o Presidente da República delegou aos ministros de Estado a competência para julgar processos com penas capitais (Decreto n. ${ }^{\text {o }} 3.035$, de 27 de abril de $1999^{505}$ ).

\footnotetext{
${ }^{503}$ COSTA, 2009, p. 205.

504 É importante trazer à colação a observação de Marcos Salles Teixeira: "E uma vez que a pena de suspensão contempla diferentes motivações (aplicação originária ou aplicação, seja por reincidência, seja por agravamento, em hipóteses que a priori seriam puníveis com advertência), a exata compreensão do dispositivo legal requer maior detalhamento da expressão 'infração sujeita à pena de suspensão'. De imediato, caso o servidor comissionado tenha cometido fato enquadrável nos incisos XVII ou XVIII do art. 117 da Lei n. $^{\circ} 8.112$, de 11/12/90, para os quais se prevê originariamente a pena de suspensão [...], de forma inequívoca, sobre ele recairá o mandamento do art. 135 da mesma Lei, impondo-lhe a pena expulsiva de destituição do cargo em comissão" (TEIXEIRA, 2014, p.1068).

505 "Art. 1. ${ }^{\circ}$ Fica delegada competência aos Ministros de Estado e ao Advogado-Geral da União, vedada a
} 
Em geral, as leis orgânicas, os estatutos ou regimentos internos dos órgãos da administração pública federal contemplam a autoridade competente para instaurar o processo com a competência para também aplicar penas de advertência e de suspensão de até trinta dias, sem prejuízo das competências de autoridades superiores.

\subsection{VIAS RECURSAIS}

\subsubsection{Controle interno}

No âmbito administrativo, o servidor público pode exercer o seu direito de petição. A Lei n. ${ }^{\circ}$ 8.112/90, em seus artigos 104 a 115, previu o chamado "direito de petição", inspirado no artigo 5. ${ }^{\circ}$ XXXIII e XXXIV, da Constituição Federal, de grande utilidade para o servidor público na defesa de direito ou interesse legítimo perante a Administração Pública. Engloba o direito de petição os seguintes institutos: o requerimento, o pedido de reconsideração e o recurso hierárquico (conforme artigos 105 a 107 da Lei n. ${ }^{o}$ 8.112/90).

É importante estabelecer a diferença feita por Marcos Salles Teixeira entre requerimento em sentido amplo e requerimento em sentido estrito:

É necessário de imediato destacar que o termo gera certa confusão, visto que pode ser empregado tanto em sentido amplo como em sentido estrito. Lato sensu, "requerer" pode ser compreendido, em gênero, como o próprio direito de petição, com ele se confundindo, conforme art. 104 da Lei n. ${ }^{\circ} 8.112$, de 11/12/90. Por outro lado, há o requerimento stricto sensu do art. 105 da mesma Lei, com o qual o servidor se dirige à Administração para solicitar algo de seu interesse ou para modificar alguma situação que originariamente se mostra contrária a ele ${ }^{506}$.

subdelegação, para, no âmbito dos órgãos da administração pública federal direta, autárquica e fundacional que lhes são subordinados ou vinculados, observadas as disposições legais e regulamentares, especialmente a manifestação prévia e indispensável do órgão de assessoramento jurídico, praticar os seguintes atos: I julgar processos administrativos disciplinares e aplicar penalidades, nas hipóteses de demissão e cassação de aposentadoria ou disponibilidade de servidores; II - exonerar de ofício os servidores ocupantes de cargos de provimento efetivo ou converter a exoneração em demissão; III - destituir ou converter a exoneração em destituição de cargo em comissão de integrantes do Grupo-Direção e Assessoramento Superiores, níveis 5 e 6, e de Chefe de Assessoria Parlamentar, código DAS-101.4; IV - reintegrar ex-servidores em cumprimento de decisão judicial, transitada em julgado". Cumpre observar que a delegação de competência constante do artigo 1..$^{\circ}$ do Decreto n..$^{\circ} 3.035$, de 27 de abril de 1999, não se aplica às hipóteses de demissão de titulares de autarquias e fundações públicas e aos ocupantes de cargo de natureza especial, conforme previsão expressa no $\S 2 .^{\circ}$ do mesmo artigo ("O disposto neste artigo não se aplica ao ocupante de cargo de natureza especial e ao titular de autarquia ou fundação pública”). Assim, a demissão de tais autoridades ainda compete ao Presidente da República.

506 TEIXEIRA, 2014, p. 1219-1220. 
É importante frisar que, como o direito de petição não se insere na Lei n. ${ }^{\circ}$ 8.112/90, em relação à matéria disciplinar, é de difícil concretização a aplicação do requerimento stricto sensu no processo administrativo disciplinar.

Dessa forma, é possível identificar, a partir dos artigos 106 a 108 da Lei n. ${ }^{o}$ 8.112/90, os institutos que concretizam o duplo grau de jurisdição na prática da matéria disciplinar: o pedido de reconsideração, dirigido à própria autoridade que decidiu, e o recurso hierárquico, dirigido às autoridades superiores ${ }^{507}$.

O pedido de reconsideração (artigo 106 da Lei $\mathrm{n}^{\circ}{ }^{8}$ 8.112/90) é dirigido à autoridade que houver expedido o ato ou proferido a primeira decisão que se pretende reformar, não podendo ser renovado, ou seja, só pode ser feito uma única vez.

Quanto ao que deve conter no pedido de reconsideração, Marcos Salles Teixeira explica:

Com o pedido de reconsideração, tanto se pode trazer à tona algum fato que não foi objeto da decisão, como se pode tão-somente debater mero entendimento jurídico ou divergência sobre a percepção de um fato já apresentado. Em outras palavras, para o pedido de reconsideração, requer-se, ao menos, a apresentação de argumento novo ${ }^{508}$.

O recurso hierárquico ou simplesmente "recurso" (artigo 107 da Lei n. 8.112/90) é dirigido à autoridade imediatamente superior à que tiver expedido o ato ou proferido a decisão que se quer reformar, sucessivamente, em escala ascendente, às demais autoridades.

No recurso hierárquico pode ocorrer que outra autoridade, sob mesmo conjunto probatório, mesmo sem haver argumento novo, tenha outro entendimento, reformando a decisão. Não cabe pedido de reconsideração à autoridade superior que indeferiu recurso hierárquico $^{509}$.

O artigo 107, § 1. , utiliza a palavra "sucessivamente"; na ausência de delimitação na Lei n. ${ }^{\circ} 8.112 / 90$, aplica-se o dispositivo do artigo 57 da Lei n. ${ }^{\circ} 9.784$, de 29 de janeiro de 1999, que limita o recurso administrativo a três instâncias administrativas, salvo disposição legal diversa.

\footnotetext{
${ }^{507}$ Marcos Salles Teixeira ressalta que o pedido de reconsideração e o recurso hierárquico devem ser utilizados com cautela, pois não são institutos previstos especificamente nos Títulos IV e V da Lei n. ${ }^{\circ}$ 8.112/90, que tratam unicamente da matéria disciplinar. "A rigor, a Lei n. ${ }^{\circ} 8.112 / 90$ não prevê um recurso específico do processo administrativo disciplinar. Nesta instância, a possibilidade de reforma está prevista tão-somente no instituto da revisão processual, que, doutrinariamente, não é um recurso em sentido estrito (TEIXEIRA, 2014, p. 1220).

508 TEIXEIRA, 2014, p. 1224.

509 TEIXEIRA, 2014, p. 1224.
} 
O prazo de interposição do pedido de reconsideração e do recurso hierárquico é de trinta dias da ciência da decisão que se quer reformar.

Em caso de provimento do pedido de reconsideração ou do recurso hierárquico, os efeitos da decisão retroagem à data do ato impugnado, sendo afastados todos os efeitos da decisão punitiva recorrida, restabelecendo o status quo, ou seja, restabelecendo-se integralmente a situação funcional do servidor na data daquele ato anulado ou revogado (artigo 109 da Lei n. ${ }^{\circ} 8.112 / 90$ ).

A decisão torna-se definitiva no âmbito administrativo, se não for apresentado recurso hierárquico no prazo de trinta dias da decisão, ou em caso de pedido de reconsideração.

A revisão cabe a qualquer tempo, a pedido ou de ofício, quando se aduzirem fatos $\operatorname{novos}^{510}$ ou circunstâncias suscetíveis de justificar a inocência do punido ou a inadequação da penalidade aplicada (artigo 174 da Lei n. ${ }^{o}$ 8.112/90).

A diferença entre o pedido de reconsideração e o recurso hierárquico, de um lado, e a revisão, de outro, reside no fato de que, enquanto os primeiros ocorrem ainda no mesmo processo original, antes da sua decisão definitiva, a revisão dá-se contra sindicância ou processo administrativo disciplinar já encerrado. E um não depende do outro.

Como consequência, haverá a instauração de um novo processo, a ser apensado ao processo originário que se quer rever e a ser conduzido por outra comissão (artigo 178 da Lei n. $\left.{ }^{\circ} 8.112 / 90\right)$.

A revisão é uma espécie de ação rescisória no processo civil, sem prazo.

\subsubsection{Controle externo}

O controle externo, para o processo administrativo, significa uma verdadeira garantia constitucional do livre ingresso no Poder Judiciário, visando a discussão de questão restrita à legalidade (artigo 5. ${ }^{\circ}, \mathrm{XXXV}$, da Constituição Federal).

É importante lembrar que o esgotamento da via administrativa não é pressuposto para o ingresso no Poder Judiciário. Além disso, cabe ao Judiciário apreciar a regularidade do procedimento, com base nos princípios da legalidade, do contraditório, da ampla defesa

\footnotetext{
510 Esclarecendo o que seja fato novo, Marcos Salles Teixeira afirma: "E este fato novo não significa, necessariamente, fato recente, mas sim algo de que não se tinha conhecimento quando do processo originário. O fato até pode ser antigo, mas novo como instrumento de prova no processo administrativo disciplinar" (TEIXEIRA, 2014, p. 1232).
} 
e do devido processo legal, sem adentrar no mérito administrativo. Lê-se no voto emitido no Mandado de Segurança n. ${ }^{\circ} 7.985$, do STJ:

[...] no que diz respeito ao controle jurisdicional do processo administrativo disciplinar, a jurisprudência desta Corte é firme no sentido de que compete ao Poder Judiciário apreciar a regularidade do procedimento, à luz dos princípios do contraditório, da ampla defesa e do devido processo legal, sem, contudo, adentrar no mérito administrativo ${ }^{511}$.

Ocorre que atualmente a jurisprudência, por força dos princípios da proporcionalidade, dignidade da pessoa humana e culpabilidade, aplicáveis ao regime jurídico disciplinar, tem entendido que não há juízo de discricionariedade no ato administrativo que impõe sanção a servidor público em razão de infração disciplinar. Do Mandado de Segurança n. ${ }^{\circ} 13.622$ do Superior Tribunal de Justiça, extrai-se o seguinte trecho: "O controle jurisdicional é amplo, de modo a conferir garantia a todos os servidores contra eventual arbítrio, não se limitando, portanto, somente aos aspectos formais, como algumas correntes doutrinárias ainda defendem" ${ }^{512}$.

Citam-se os seguintes meios recursais judiciais: mandado de segurança; ação civil ordinária; ação reintegratória (artigo 28 da Lei n. ${ }^{\circ}$ 8.112/90) e ação cautelar.

Buscou-se demonstrar de forma clara o iter processual a ser seguido para a apuração das faltas disciplinares dos servidores públicos submetidos à Lei n. ${ }^{\circ}$ 8.112/90. A partir disso, considerando as peculiaridades do servidor público temporário, será analisada a possibilidade de aplicação de tal procedimento no caso de cometimento de infrações disciplinares pelos servidores temporários em estudo, pretendendo-se estabelecer um verdadeiro regime jurídico disciplinar para os servidores públicos temporários.

\subsection{PARTICULARIDADES DO PROCESSO DE APURAÇÃO DO ILÍCITO DO SERVIDOR PÚBLICO TEMPORÁRIO}

Em que pesem a ausência de estabilidade e a precariedade do vínculo dos servidores temporários e a possibilidade de distrato a qualquer tempo, de acordo com a conveniência administrativa, caso a Administração tome conhecimento do cometimento de alguma falta disciplinar por parte do servidor temporário, será necessária a abertura de

\footnotetext{
${ }^{511}$ Podem-se ainda citar os Mandados de Segurança n. ${ }^{\circ} 20.882$, n. $^{\circ} 20.999$, n. ${ }^{\circ} 21.297$ e n. ${ }^{\circ} 22.534$, do STF, e os Mandados de Segurança n. ${ }^{\circ} 5.626$, n. $^{\circ} 5.633$, n. $^{\circ} 6.853$, n. $^{\circ} 7.019$, n. $^{\circ} 7.370$, n. $^{\circ} 8.858$ e n. ${ }^{\circ} 8.998$, do STJ.

512 Marcos Salles Teixeira ressalta: "a jurisprudência atual tem entendido que a verificação da adequação da pena aplicada com as provas fáticas constantes do processo se enquadra nos elementos vinculados do ato administrativo, de forma que o conteúdo fático e a instrução probatória passam a integrar a legalidade do ato e não o seu mérito" (TEIXEIRA, 2014, p. 1241).
} 
processo administrativo (sindicância, no dizer da Lei n. ${ }^{\circ} 8.745 / 93$ ou processo sumário) para sua apuração.

Verificou-se, ao tratar do histórico do servidor temporário, que o Decreto-Lei n. ${ }^{\circ}$ 5.157, de 7 de janeiro de 1943, já previa uma ação disciplinar para os extranumerários.

Art. 10. Aplicam-se ao extranumerário as disposições do decreto-lei n. ${ }^{\circ}$ 1.713 , de 28 de outubro de 1939, referentes aos deveres e ação disciplinar, independendo, porém, a dispensa de inquérito administrativo. Parágrafo único. Competirá ao chefe de serviço dispensar extranumerário, promovendo imediata comunicação à D.P. correspondente, para as devidas publicação e providências. [...]

Art. 15. Será punido com a pena de repreensão o servidor que cometer engano, erro ou omissão na instrução dos atos relativos ao preenchimento de função de extranumerário, ou for o responsável pela inobservância das determinações deste decreto-lei.

Parágrafo único. Será punido com a pena de suspensão o servidor que der exercício a extranumerário, cujo admissão não for aprovada, por desrespeito às prescrições deste decreto-lei, além de responsabilizado, pecuniariamente, cabendo-lhe o direito regressivo contra aqueles que intervierem no respectivo processamento.

Atualmente, o artigo 10 da Lei n. ${ }^{\circ}$ 8.745/93 esclarece que as infrações disciplinares atribuídas aos servidores temporários serão apuradas mediante sindicância, concluída no prazo de até trinta dias e assegurada a ampla defesa. Ocorre que a Lei n. ${ }^{\circ}$ 8.745/93 não aplica aos servidores temporários o rito estabelecido na Lei n. ${ }^{\circ} 8.112 / 90$ para os servidores submetidos ao regime estatutário.

Por sua vez, o artigo 11 da Lei n. ${ }^{\circ} 8.745 / 93$ estabelece que se aplicam ao pessoal contratado temporariamente os artigos da Lei n. ${ }^{\circ} 8.112 / 90$, que tratam, na matéria disciplinar, de algumas irregularidades, responsabilidade, penalidades e prescrição. $\mathrm{O}$ artigo 11 da Lei n. ${ }^{\circ} 8.745$, de 9 de dezembro de 1993 dispõe:

Aplica-se ao pessoal contratado nos termos desta Lei o disposto nos arts. 53 e 54; 57 a 59; 63 a 80; 97; 104 a 109; 110, incisos, I, 'in fine', e II, parágrafo único, a 115; 116, incisos I a V, alíneas a e c, VI a XII e parágrafo único; 117, incisos I a VI e IX a XVIII; 118 a 126; 127, incisos I, II e III, a 132, incisos I a VII, e IX a XIII; 136 a 142, incisos I, primeira parte, a III, e $\$ \S 1 .^{\circ}$ a $4 .^{\circ} ; 236 ; 238$ a 242 , da Lei n..$^{\circ} 8.112$, de 11 de dezembro de 1990.

Observa-se que não há referência ao rito processual previsto nos artigos 143 a 182 da Lei n. ${ }^{\circ}$ 8.112/90, mas curiosamente se aplica o artigo 140 da Lei n. ${ }^{\circ}$ 8.112/90 aos servidores temporários em caso de apuração de abandono de cargo ou de inassiduidade habitual, quando é adotado o procedimento sumário constante do artigo 133 da Lei n. ${ }^{\circ}$ $8.112 / 90$. 
Isso significa que, para a apuração e a responsabilização dos ilícitos administrativos cometidos pelos servidores temporários, não há obrigação de seguir o rito processual estabelecido na Lei n. ${ }^{\circ}$ 8.112, de 11 de dezembro de 1990, em razão das características de tais servidores, mas há, sim, necessidade de respeitar as cláusulas do devido processo legal (do artigo 5. ${ }^{\circ}$, LIV, da Constituição Federal), da ampla defesa e do contraditório (do artigo 5. ${ }^{\circ}, \mathrm{LV}$, da Constituição Federal c/c artigo 10 da Lei n. $\left.{ }^{\circ} 8.745 / 93\right)^{513}$.

Depreende-se da análise dos dispositivos acima citados que os servidores temporários estão sujeitos aos procedimentos de apuração de abandono de cargo ou de inassiduidade habitual, na qual é adotado o procedimento sumário, por força do artigo 11 da Lei n. ${ }^{\circ} 8.745 / 93$.

É importante observar que o servidor público temporário ocupa função. Então, especificamente para o servidor público temporário, poderíamos dizer que o procedimento sumário é utilizado para os casos de abandono de função ou de inassiduidade habitual. Isso porque o artigo 11 da Lei n. ${ }^{\circ} 8.745 / 93$ estende a aplicação do artigo 136 a 140 da Lei n. ${ }^{\circ}$ 8.112/90 aos servidores públicos temporários.

Entende-se que, na acumulação ilegal de cargos, empregos ou funções, os servidores temporários também estariam sujeitos ao procedimento sumário, pois ocupam funções. Além disso, por força do artigo 11 da Lei n. ${ }^{\circ}$ 8.745/93, aplica-se aos temporários o artigo 118 a 120 da Lei n. ${ }^{\circ} 8.112 / 90^{514}$.

\footnotetext{
${ }^{513}$ Em homenagem aos mencionados princípios constitucionais do devido processo legal e da ampla defesa, os Acórdãos n. ${ }^{\circ} 181868$ e n. ${ }^{\circ} 181869$, proferidos pelo Tribunal de Justiça do Distrito Federal e dos Territórios em 13 de outubro de 2002, condicionaram à instauração de prévia sindicância a aplicação de sanção disciplinar a servidor público temporário.

514 REEXAME NECESSÁRIO. MANDADO DE SEGURANÇA. CONCURSO PÚBLICO. ACUMULAÇÃO DE CARGOS. ART. 37, INCISO XVI, ALÍNEA "B", DA CF/88. CONTRATAÇÃO TEMPORÁRIA. LEI 8.745/93. ADMISSIBILIDADE. TEORIA DO FATO CONSUMADO. SEGURANÇA CONCEDIDA. 1. A Constituição de 1988 , em seu art. $37, \S 3 .^{\circ}$, inciso X, prevê a possibilidade de acumulação de um cargo de professor com outro técnico ou científico, mas não estabelece distinção quanto à forma de provimento do cargo técnico, se em caráter efetivo ou temporário, motivo pelo qual é razoável entender estar nele (art. 37, XVI, CF) incluída a possibilidade de contratação para atender a necessidade temporária de excepcional interesse público prevista na Lei n. ${ }^{\circ} 8.745 / 93$. 2. O impetrante submeteu-se a um processo seletivo para agente censitário, no qual se exigiram conhecimentos técnicos específicos necessários ao desempenho da atividade, daí por que se pode afirmar que se trata de cargo técnico. 3. Ademais, na hipótese, considerando que, por força da decisão judicial proferida em 27.03.2007, foi assegurada ao impetrante a celebração do contrato de trabalho pleiteado nos autos, cuja previsão de execução dos trabalhos era de 07 (sete) meses, bem como o fato de que a validade do concurso já expirou, há de se aplicar, na espécie, a teoria do fato consumado, haja vista que o decurso do tempo consolidou uma situação fática amparada por decisão judicial, sendo desaconselhável e até mesmo impossível a sua desconstituição. 4. Remessa oficial a que se nega provimento (TRF1 - REOMS 9892520074014000 - REOMS - REMESSA EX OFFICIO EM MANDADO DE SEGURANÇA - 9892520074014000 - Relator: DESEMBARGADOR FEDERAL KASSIO NUNES MARQUES - SEXTA TURMA - Fonte: e-DJF1 DATA: 28/11/2013 PAGINA: 227 - Data da decisão: 11/11/2013 - Data da publicação: 28/11/2013). Nesse sentido: TRF2 - AC 201251010053967 - AC - APELAÇÃO CIVEL - 614942 - Relator: Desembargador Federal MARCUS
} 
Objetiva-se apresentar um caminho razoável a ser seguido, visto que a realidade dos servidores temporários é muito comum na Administração Pública brasileira, e precisa haver um procedimento para o caso do regime disciplinar dos servidores públicos temporários.

\subsubsection{Sindicância (denominação da Lei n. ${ }^{\circ}$ 8.745/93)}

A sindicância é o instrumento eleito pela Lei Federal n. ${ }^{\circ}$ 8.745/93 para apurar as infrações atribuídas ao pessoal contratado por tempo determinado para atender a necessidade temporária de excepcional interesse público (o artigo 10 da citada Lei faz referência à apuração das infrações disciplinares mediante sindicância, concluída no prazo de trinta dias e assegurada a ampla defesa).

Assim, a sindicância constante da Lei n. ${ }^{\circ}$ 8.112/90 destina-se a apurar faltas cuja punição poderá resultar na aplicação de penalidade de advertência ou de suspensão de até 30 (trinta) dias; poderá haver o arquivamento do processo ou a instauração de processo disciplinar. Portanto, é utilizada no caso de faltas mais leves.

Pelo artigo 11 da Lei n. ${ }^{\circ}$ 8.745/93, são aplicáveis ao pessoal contratado por tempo determinado para atender a necessidade temporária de excepcional interesse público alguns artigos da Lei n. ${ }^{\circ}$ 8.112/90, entre os quais o artigo 127, I, II e III. Logo, os servidores temporários estão sujeitos às seguintes penalidades disciplinares: advertência, suspensão e demissão.

Dessa forma, as faltas disciplinares dos servidores públicos temporários são apuradas mediante sindicância que poderá ter como resultado uma advertência, uma suspensão ou uma demissão, sempre observada a ampla defesa e o contraditório.

Para os demais servidores públicos submetidos ao regime da Lei n. ${ }^{\circ}$ 8.112/90, a sindicância destina-se a apurar faltas cuja punição poderá resultar na aplicação de penalidade de advertência ou de suspensão de até 30 (trinta) dias; poderá haver o arquivamento do processo ou a instauração de processo disciplinar (artigo 145 da Lei n. ${ }^{\circ}$ 8.112/90). Assim, se a suspensão for por mais de 30 dias ou para a aplicação de uma demissão, deverá ser instaurado o processo administrativo disciplinar.

$\mathrm{O}$ processo disciplinar destina-se à apuração de transgressões reprimíveis com penas mais graves, como suspensão superior a trinta dias, demissão e cassação de 
aposentadoria ou de disponibilidade. Quanto ao processo sumário, é utilizado para o processamento dos delitos disciplinares de acumulação de cargos, abandono de cargo e inassiduidade habitual ao serviço, conforme os artigos 133 e 140 da Lei n. ${ }^{\circ}$ 8.112/90.

Algumas dúvidas e perguntas rondam, porém, tal questão. Há situações em que poderá haver até demissão, dependendo da falta funcional que o servidor temporário praticar. Parece haver uma contradição, pois como será aplicada a penalidade de demissão mediante uma sindicância? Sem esquecer que não há obrigatoriedade de seguir o rito da Lei n. ${ }^{\circ} 8.112 / 90$.

Diante dessa realidade, observa-se que a sindicância de que trata a Lei n. ${ }^{\circ}$ 8.745/93 é uma sindicância sui generis, pois permite a aplicação da penalidade de suspensão por mais de trinta dias e a demissão, o que, segundo a essência da Lei n. ${ }^{\circ}$ 8.112/90, não seria possível pela apuração de sindicância, somente por processo administrativo disciplinar.

Para tentar conciliar as situações, visto que se está diante de uma situação nova e de uma realidade diferente, apresentar-se-á uma solução para resolver o problema, sugerindose um procedimento a ser seguido (independentemente do nome e de suas características sindicância ou processo administrativo) que seja compatível com as peculiaridades do servidor público temporário.

O processo administrativo disciplinar rege-se pelo princípio do formalismo moderado $^{515}$, além de outros, que, juntamente com o princípio da eficiência ${ }^{516}$ e do interesse público de alcançar a verdade material ${ }^{517}$, guiam o desenvolvimento do rito

\footnotetext{
${ }^{515}$ Princípio previsto nos incisos VIII e IX do parágrafo único do artigo $2 .^{\circ}$ e no artigo 22 da Lei n. ${ }^{\circ} 9.784$, de 29 de janeiro de 1999. Decorre do preceito constitucional do alcance da eficiência. Busca evitar que os exageros formais dificultem ou impeçam a participação do servidor quando do exercício das garantias da ampla defesa e do contraditório. "Em síntese, dispensam-se formas rígidas e ritos sacramentais, bastando se adotar formas simples, estritamente necessárias para assegurar a certeza jurídica e a segurança procedimental do ato praticado, salvo expressa determinação legal em contrário ou se o ato atinge direito do acusado" (TEIXEIRA, 2014, p. 377). Na busca da verdade material, mais importa o conteúdo que a forma dos atos. Assim, não se cogita de nulidade no processo administrativo disciplinar por mera inobservância de forma que não tenha acarretado concreto prejuízo à defesa.

${ }^{516}$ Previsto no caput do artigo 37 da Constituição Federal, o princípio da eficiência significa, no processo administrativo disciplinar, que a administração deve concluir, em tempo razoável, pela absolvição ou pela responsabilização do servidor. Essa decisão deve decorrer de um procedimento simplificado na forma, com celeridade e economia processual. Devem-se evitar as formalidades, a protelação, a omissão e a burocracia.

517 Vigora, no âmbito do direito administrativo disciplinar, no que concerne à prova, o princípio da verdade material ou real. Por isso, a comissão de inquérito deve trazer para os autos os elementos probatórios legítimos, adequados e eficazes para, se for o caso, a elaboração da indiciação e do relatório e para a formação do convencimento da autoridade julgadora. É de se destacar, portanto, que o colegiado deve lançar mão de todos os meios de prova admitidos em nosso direito, desde que moralmente legítimos (artigo 332 do Código de Processo Civil e artigo 212 do Código Civil), tudo em consonância com o princípio da verdade material ou real e com observância da regra do artigo 155 da Lei n. ${ }^{\circ} 8.112 / 90$, que fala em "investigações e diligências cabíveis", e do inciso LVI do artigo 5..$^{\circ}$ da Constituição Federal, assim redigido: "São inadmissíveis, no processo, as provas obtidas por meios ilícitos".
} 
processual a ser adotado, principalmente no caso da apuração de faltas dos servidores públicos temporários, em que não há um procedimento propriamente dito.

Detectada a ocorrência de falta disciplinar cometida por servidor temporário, impõe-se sua apuração. A Lei n. $8.745 / 93$ denomina tal procedimento "sindicância". Ressalta-se que essa sindicância não é investigativa ${ }^{518}$, mas é o meio de apurar as faltas disciplinares dos servidores temporários.

Dessa forma, à semelhança do rito do processo administrativo, adotar-se-ão as seguintes fases para a apuração de faltas dos servidores temporários: instauração, inquérito administrativo (que compreende instrução, defesa, relatório) e julgamento.

A instauração ocorre com a publicação do ato que constitui a comissão, composta por três servidores estáveis, de nível hierárquico igual ou superior ao do acusado. Isso se justifica pela qualidade do conselho sindicante. Há uma maior segurança jurídica para o alcance da justiça, se o exame das provas e razões de defesa for realizado por um colegiado em lugar de um sindicante. Além disso, nessa sindicância, poderá ser aplicada a penalidade de demissão do servidor público temporário; logo, é prudente que a comissão seja composta por três servidores.

A comissão deve ser designada pela autoridade administrativa com ascendência hierárquica sobre o servidor temporário acusado.

$\mathrm{Na}$ apuração de faltas dos temporários, aplicam-se as mesmas regras relativas a impedimentos, suspeições, imparcialidade e independência dos membros da comissão que são aplicáveis nos procedimentos anteriormente expostos do processo administrativo disciplinar e da sindicância, previstos na Lei n. ${ }^{\circ}$ 8.112/90.

As mesmas observações tecidas sobre a portaria inicial do procedimento ordinário constante da Lei n. ${ }^{\circ}$ 8.112/90 (servidores públicos estatutários) também devem ser estendidas aos servidores temporários.

A fase de inquérito administrativo compreende a instalação da comissão processante, a comunicação da instalação e a designação do secretário. A parte instrutória envolve a notificação do servidor para acompanhar o processo como acusado ou imputado, a tomada de depoimentos, as perícias e diligências, o interrogatório, a indiciação para apresentar defesa escrita, a defesa escrita e o relatório. Assim, a instrução sumária, compreende a indiciação, a defesa e o relatório.

${ }^{518}$ Nada impede que se possa instaurar uma sindicância investigativa para apurar os fatos. 
Basicamente, é adotado o mesmo rito processual do processo administrativo disciplinar, com algumas variações de prazo e de número de testemunhas, e com perícias de pouca complexidade.

O prazo de três dias de antecedência (prazo reduzido) entre a intimação do acusado e a audiência de inquirição de testemunhas e outros atos processuais atende perfeitamente à garantia da ampla defesa do acusado no caso do processo disciplinar do servidor temporário.

O servidor temporário poderá arrolar até duas testemunhas. Após a oitiva das testemunhas, deverá haver o interrogatório do acusado.

A comissão deverá manifestar-se sobre o arquivamento ou sobre a indiciação do acusado. Se a autoridade instauradora concordar com a sugestão do arquivamento, o acusado será absolvido antecipadamente.

Constatada a prática de transgressão disciplinar, a comissão opinará pela indiciação do acusado, apontando, numa síntese escrita - o chamado "despacho de instrução e indiciação" -, as razões de fato e de direito da indiciação e indicando a lei, o regulamento em que deve ser feito o enquadramento.

Em seguida, deve ser aberto um prazo de cinco dias para o oferecimento da defesa escrita (prazo reduzido), mediante citação por mandado expedido pelo presidente do colegiado processante, sendo assegurada ao acusado a vista do processo.

Apresentada a defesa, a comissão, no prazo de três dias (prazo reduzido), elaborará um relatório conclusivo quanto à inocência ou à responsabilidade do servidor, resumindo as peças principais dos autos, indicando o(s) respectivo(s) dispositivo(s) legal(ais), sugerindo a penalidade a ser aplicada, remetendo a sindicância à autoridade instauradora para julgamento.

No prazo de cinco dias (prazo reduzido) contados do recebimento do processo, a autoridade julgadora proferirá a sua decisão.

Adotam-se prazos reduzidos para a realização dos atos processuais. Entende-se razoável o prazo de 30 dias para a conclusão dos trabalhos, pois se trata de um contrato por tempo determinado, para atendimento de necessidade temporária de excepcional interesse público. São ou devem ser situações de curto prazo, então não há por que estender as apurações por mais de trinta dias, mas sempre se deve respeitar o contraditório e a ampla defesa.

Defende-se que cabe tanto o pedido de reconsideração quanto o recurso hierárquico da decisão proferida pela autoridade julgadora, em razão do princípio da ampla defesa. $\mathrm{O}$ 
prazo de interposição é de dez dias (redução do prazo) a partir da ciência da decisão que se quer reformar.

Já o pedido de revisão não é compatível com as características do servidor temporário, que não possui estabilidade, foi contratado por tempo determinado para atender a necessidade temporária de excepcional interesse público, exercendo função.

O afastamento preventivo do acusado não é medida compatível com a característica do servidor público temporário, portanto não se justifica sua aplicação para os temporários.

Diante dessa realidade, há sem dúvida um "princípio de equiparação". O servidor temporário, contratado por tempo determinado para atender a necessidade temporária de excepcional interesse público, é uma espécie de servidor público do gênero agente público. Ficando comprovado que a responsabilidade dos servidores públicos temporários é igual à dos demais servidores públicos (“não temporários"), ou seja, que ambos respondem, deve haver um processo administrativo disciplinar (ou sindicância ou processo sumário) para apuração das faltas, estabelecido por intermédio de um regime jurídico disciplinar a ser observado.

Como o vínculo temporário é reduzido, é especial, conforme se pode deduzir das características do servidor temporário, o processo administrativo disciplinar destinado a apurar a falta cometida pelo servidor público temporário também é reduzido, especial, mas impõe-se a necessidade de haver uma forma de apuração das faltas, bem como o estabelecimento de um rito processual a ser cumprido.

Daí a necessidade de construir, com base nas características próprias dessa espécie de servidor público, um regime adaptado às especificações do vínculo especial a que se submete o servidor público temporário. Estar-se-á diante de um miniprocesso disciplinar ou de um processo disciplinar especial, ou de uma minissindicância ou de uma sindicância especial, sui generis. 


\section{CONCLUSÕES}

Historicamente, nota-se a presença do servidor temporário na Administração Pública brasileira, com diferentes nomes, mas conservando suas características principais. Tal figura exerceu um importante papel ao longo dos anos. Já em 1943, havia a previsão de uma ação disciplinar para os extranumerários: o Decreto-Lei n. ${ }^{\circ}$ 5.157, de 7 de janeiro de 1943, indicava a necessidade de ser organizada uma forma de apuração dos ilícitos praticados por tais servidores públicos.

O servidor temporário não é uma figura exclusiva do direito brasileiro, pois, no direito estrangeiro, em especial na França e em Portugal, podem-se encontrar semelhanças com o chamado servidor temporário do Brasil. Frise-se: as figuras não são iguais, a ideia é parecida, mas o tratamento diferente.

Em razão da União Europeia, sente-se uma grande influência de normas internacionais e europeias no direito administrativo dos países que integram a Comunidade Europeia. Principalmente em Portugal, nota-se uma forte tendência de aproximação dos setores público e privado. O direito da União Europeia projeta-se sobre a disciplina do emprego público.

Sem dúvida que, se não em todos os países, na maioria há necessidades de excepcional interesse público, justificando a existência do servidor público temporário ou de uma figura com denominação diferente, mas com características assemelhadas.

Ao longo do trabalho, defende-se que o servidor temporário está enquadrado como agente público. Filia-se à corrente que classifica os temporários como espécie de servidores públicos do gênero agentes públicos. Assim, o temporário é um agente público da espécie servidor público.

Os servidores públicos temporários não ocupam cargo ou emprego, não se exigindo, necessariamente, concurso público, pois a excepcionalidade e a urgência da contratação são incompatíveis com a demora da realização do concurso público. Os temporários exercem função, com fulcro no artigo 37, IX, da Constituição Federal, ou seja, desempenham um conjunto de atribuições previstas para o desenvolvimento de uma atividade pública.

Quanto ao regime jurídico dos servidores temporários, não há uma unanimidade entre os doutrinadores, que defendem ser regime público especial, regime estatutário, 
regime celetista, contrato administrativo inominado submetido ao regime das aquisições públicas (Lei das Licitações n. ${ }^{\circ}$ 8.666/93) ou, ainda, contrato civil de prestação de serviços.

Embora a Constituição Federal utilize o termo "contratação", isso não significa que o regime a que o servidor temporário tenha de submeter-se seja o celetista. Não se pode esquecer que os servidores temporários exercem temporariamente função, não ocupam cargo ou emprego público, e, conforme já foi reconhecido pelo Supremo Tribunal Federal, os contratos temporários, com base em lei própria, têm natureza de regime jurídicoadministrativo.

Não se está dizendo que o regime deve ser o estatutário, mas defende-se que se trata de um regime especial e que a lei federal, estadual, municipal ou distrital é que vai definir qual será a característica de tal regime, se se aproxima do estatutário ou se se aproxima do celetista ou se será um misto dos dois regimes.

Em suma, defende-se, para os servidores temporários, a existência de um regime especial, próprio, de natureza jurídico-administrativa, mais próximo do regime estatutário e do contrato de que trata o artigo 37, IX, da Constituição Federal - embora possam ser regidos pela lei que cada ente da federação estabelecer, é possível ser aplicada a Consolidação das Leis do Trabalho, ser estabelecido um regime jurídico especial ou recorrer-se a regras do Estatuto correspondente.

Entende-se que os servidores temporários compatibilizam-se melhor com um regime especial. Para prestigiar o princípio da igualdade, deve a lei estadual, municipal ou distrital, ao editar a sua lei obedecendo ao comando constitucional, adotar, para os seus servidores temporários, um regime especial, evitando a previsão de contratos baseados no direito civil ou na Consolidação das Leis do Trabalho.

O ideal para o servidor público temporário seria a existência de um regime jurídico especial, próprio, mais próximo do regime estatuário, de natureza administrativa, ou seja, aplicando-se aquilo que guardar compatibilidade com a situação transitória de excepcional interesse público, visto que estão em jogo casos de interesse público sem qualquer conotação privada.

Assim, seja o regime estatutário, seja o regime celetista, seja o regime especial a ser aplicado aos servidores públicos temporários, para o perfeito andamento do serviço público, que não pode ficar sem nenhuma regra, os servidores públicos devem obedecer a um regime disciplinar, em razão da responsabilidade que possuem.

Defende-se que o comando constitucional do artigo 37, IX, exige a edição de uma lei que venha completá-lo e conferir-lhe possibilidade de aplicação, por tratar-se de uma 
típica norma de eficácia limitada, pois precisa de uma legislação futura, observados os casos de necessidade temporária de excepcional interesse público.

Assim, cada unidade da federação, em conformidade com suas peculiaridades e em virtude de sua autonomia, editará a lei, estabelecendo as situações de contratação temporária. Portanto, cada ente político deverá editar lei específica para realizar as contratações temporárias. O problema é o seguinte: cada esfera política poderá escolher o regime que melhor se adapte às suas necessidades, seja o estatutário, seja o celetista, seja um regime próprio.

O grande perigo é a falta de uniformidade, que gera uma desigualdade entre as situações, em razão da grande quantidade de estados e de municípios no Brasil. De fato, hoje há um temporário regido pelas normas estatutárias em um Estado e outro temporário regido por normas celetistas em outro Estado. Isso provoca uma sensação de injustiça, pois não há uma isonomia entre os entes da Federação, permite-se que cada um proceda de uma forma, adotando o regime estatutário, o regime celetista ou um regime especial, de acordo com suas conveniências.

Como a Constituição Federal diz que compete privativamente à União (artigo 22, XXVII) legislar sobre normas gerais de licitação e também de contratos administrativos, seria ideal e adequado que essas fossem normas gerais e que a contratação fosse uniformizada em todo o território nacional.

A melhor solução seria estabelecer a observância de um regime especial de natureza administrativa por todos os entes da federação, aplicando-se o que for compatível com a transitoriedade da contratação (função), os direitos e deveres referidos no respectivo estatuto dos servidores públicos, por meio de um contrato administrativo.

Poderia, pelo menos, ser adotado um regime jurídico disciplinar único, independente do regime constante da lei específica para realizar as contratações temporárias. O regime disciplinar seria aplicado em todas as situações referentes ao servidor público temporário.

Apesar de já se terem passado mais de vinte anos, não há unanimidade, nem na doutrina, nem na jurisprudência, na interpretação do dispositivo constitucional, do artigo 37, IX, da Constituição Federal, que está assim redigido: “a lei estabelecerá os casos de contratação por tempo determinado para atender à necessidade temporária de excepcional interesse público". O texto constitucional apresenta os seguintes requisitos: contratação por prazo determinado, necessidade temporária e excepcional interesse público. 
O estudo deste trabalho está relacionado ao direito administrativo (e não ao contrato por tempo determinado do direito do trabalho), ao contrato temporário de excepcional interesse público, em que a situação é "passageira”, transitória, o contrato deve ter prazo certo, ou seja, o suficiente para resolver o problema ou para providenciar um concurso.

Se é uma necessidade temporária que força o Estado a agir imediatamente sob pena de comprometimento social, não pode durar tanto tempo a ponto de não ser possível a realização de um concurso público.

As palavras-chaves que autorizam a contratação temporária são: emergência, excepcionalidade, transitoriedade, imprevisibilidade e interesse público.

Somente diante da situação concreta, poder-se-á analisar se foram ou não preenchidos os requisitos que autorizam a contratação temporária. Independentemente da finalidade - exercício de atividade permanente ou não -, a contratação sempre se deve pautar pelos princípios da motivação, da moralidade, da razoabilidade e da impessoalidade.

Além do interesse público que deve permanecer em toda atividade administrativa, segundo o dispositivo constitucional, há situações que fogem à normalidade e demandam um plus no interesse público, diante dos acontecimentos do dia a dia. Nesses casos, estarse-ia diante de situações excepcionais que fogem ao controle e autorizariam a contratação temporária.

Ainda em relação aos pressupostos fundamentais da necessidade temporária e excepcional interesse público, frisa-se que as suas hipóteses devem estar expressas em lei, de forma clara, a fim de facilitar a sua identificação, pois pode acontecer uma indeterminação dos casos em razão dos conceitos jurídicos indeterminados de necessidade temporária e "excepcional” interesse público, servindo de válvula de escape para abusos. $\mathrm{Ou}$, ao contrário, o legislador deveria usar expressões abertas de modo a flexibilizar as situações de contratação temporária e evitar uma enxurrada de medidas provisórias?

Os conceitos jurídicos indeterminados são uma arma poderosíssima, que deve ser manuseada com bastante cautela, sempre visando o interesse público, a coletividade.

Portanto, de acordo com o pensamento aqui esposado, a menção a conceitos jurídicos indeterminados pela lei pode ou não conduzir à atribuição de atuação discricionária à Administração Pública. A solução para a questão somente pode ser fornecida casuisticamente.

Com efeito, a técnica dos conceitos jurídicos indeterminados permite ao legislador decidir se a utilização de um conceito deve conduzir a uma certa liberdade do 
administrador ou se a lei deve regular exaustivamente o seu comportamento. O importante é, pois, que tal liberdade seja bem utilizada, e não distorcida.

Assim, o artigo 37, IX, da Constituição Federal é destinado a situações em que a própria atividade a ser desempenhada é temporária. Nesses casos, não haveria viabilidade para o concurso público, que se dispõe a prover cargos e empregos de natureza permanente. Além disso, mesmo que a atividade seja permanente, o excepcional interesse público demanda que se faça imediato suprimento de uma necessidade temporária, por não haver tempo hábil para realizar o concurso.

Dependendo do caso concreto, da necessidade, da gravidade da situação, pode-se até contratar diretamente, mas desde que esse ato esteja devidamente motivado, fundamentado. O que não se admite é a contratação de qualquer pessoa sem o mínimo de qualificação para o exercício da função.

A contratação por prazo determinado para atender a necessidade temporária de excepcional interesse público, nos moldes estabelecidos no artigo 37, IX, da Constituição Federal, deve estar em sintonia com os princípios que regem a vida da Administração Pública.

Um dos fundamentos para a contratação temporária é justamente o fato de que o serviço público não pode parar (hospital, universidade) ou deve ser prestado por mais pessoas (quando ocorre uma epidemia); portanto, em uma situação excepcional, contratamse pessoas para o exercício da função. Pelo princípio da continuidade do serviço público, o serviço público não pode parar, em razão disso criou-se uma válvula de escape (dispositivos) para fazer face a determinadas situações do cotidiano que permitam a continuidade do serviço, eis a razão da criação ao artigo 37, IX, da Constituição Federal. É importante ressaltar que o princípio da continuidade nem sempre significa atividade ininterrupta, basta que a atividade seja apenas regular, em conformidade com a natureza e a forma de prestação do serviço.

Dentre as consequências que decorrem da paralisação dos serviços públicos, destaca-se a "proibição" de greve nos serviços públicos. Reconhece-se que o Supremo Tribunal Federal deu um salto importante tentando tornar efetivo um direito consagrado na Constituição Federal, que é o direito de greve dos servidores públicos, ao determinar a aplicação de um instituto de direito privado - a Lei n. ${ }^{\circ}$ 7.783/89 - analogicamente ao servidor público civil.

De igual modo, o princípio da moralidade deverá desempenhar o papel de limite nos casos de contratação temporária. $\mathrm{O}$ agente público deve ser um bom administrador, 
pois está gerindo recursos alheios, devendo agir com eficiência, zelo, parcimônia, honestidade e, sobretudo, com a observância da boa-fé, ou seja, fazendo com que as contratações temporárias obedeçam ao princípio da moralidade administrativa, buscando sempre o interesse público. Portanto, o princípio da moralidade nada mais é do que atender ao interesse público com legalidade ética.

No presente estudo, o princípio da impessoalidade significa que a Administração não pode agir motivada por interesses particulares, por interesses políticos, de grupos, por animosidades ou simpatias pessoais, políticas, ideológicas etc. O princípio da impessoalidade implica sempre uma regra de agir objetiva para o administrador, de forma a atender ao fim legal de interesse público. O princípio da impessoalidade exerce um papel importante na seleção das pessoas que serão contratadas temporariamente.

É certo que, somente em cotejo com os demais princípios constitucionais, somente com a observância da realidade e da situação concreta em que ocorre a atuação administrativa, podem-se determinar a razoabilidade e a proporcionalidade, em conformidade com standards ou padrões de comportamento vigentes na sociedade em dada ocasião. Com efeito, o limite do prazo do contrato temporário deve atender aos princípios da proporcionalidade e da razoabilidade. $\mathrm{Na}$ aplicação das sanções administrativas, deverão ser observados os princípios da razoabilidade e da proporcionalidade, que assumem um importante espaço em matéria de controle jurisdicional.

É importante que a contratação temporária seja devidamente motivada, entrando em cena o princípio da motivação, segundo o qual as razões de fato e de direito que autorizam a contratação devem ser expostas, sob pena de nulidade.

A maioria dos casos em que se recorre à contratação temporária tem por objetivo solucionar ou minimizar problema repentinamente surgido. São situações que ultrapassam a normalidade, são contratações provisórias em casos excepcionais que precisam ser solucionados imediatamente.

Entende-se que, na Lei n. ${ }^{\circ}$ 8.745, de 9 de dezembro de 1993, criada para regulamentar o inciso IX do artigo 37 da Constituição da República, foram realmente previstos casos de necessidade temporária de excepcional interesse público. As situações criadas pela lei visam preservar as seguintes áreas: saúde, educação, segurança, ambiental, calamidade pública. Paira dúvida sobre a constitucionalidade das demais situações criadas posteriormente pelo legislador ordinário, pelas leis e medidas provisórias posteriores. 
Ressalta-se que a admissão temporária no serviço público sem o devido concurso público só é possível em situação restrita de excepcional interesse público. Não há na lei que estabelece casos de contratação temporária nenhuma discricionariedade conferida pela Constituição. Deve ser observado única e exclusivamente o atendimento de necessidade temporária de excepcional interesse público.

As contratações temporárias fraudulentas são uma realidade, e o legislador ordinário e o Executivo, por via de medidas provisórias, são os principais culpados pelas fraudes na contratação temporária.

O grande perigo é que o concurso público para ingresso no serviço público deixe de ser a regra, e ocorra a "fuga para o direito privado". O importante é ressaltar que só pode haver contratação temporária em casos de necessidade temporária para atender excepcional interesse público. Isso é a exceção, e não a regra. A regra é o concurso público.

De acordo com a jurisprudência, os casos de contratação temporária devem estar expressamente definidos em lei, a contratação deve ser temporária e deve haver excepcional interesse público. O Supremo Tribunal Federal, em diversas ações, deixa claro que é imprescindível para a contratação temporária a comprovação da necessidade temporária de excepcional interesse público.

Quanto à responsabilidade, um primeiro ponto deve ser considerado: gera responsabilidade a ocorrência de um fato ou de um ato (ou de uma omissão).

Quanto à questão de definir se o ato jurídico é lícito ou ilícito para causar a responsabilidade do agente público, defende-se que o ato jurídico pode ser tanto lícito quanto ilícito, apesar de ser mais fácil identificar a responsabilidade na prática de um ato jurídico ilícito.

Ao praticar um ato ilícito, o agente comete uma infração a um dever de conduta, por intermédio de ações ou omissões culposas ou dolosas, o que resulta em dano para outrem.

Aquele que causa um desequilíbrio na ordem natural-legal da sociedade deve responder por isso. A ilicitude é, antes de tudo, quebra ou infração de norma posta.

A ilicitude está presente em diversas áreas. Focalizou-se no presente trabalho o ilícito administrativo, civil, penal e por ato de improbidade administrativa e a responsabilidade daí decorrente, mais especificamente a responsabilidade administrativa causada pela prática do ilícito administrativo.

Ocorre a prática do ilícito administrativo quando o agente público, no exercício de suas funções, infringir deveres e proibições constantes do regime jurídico ao qual está submetido. 
Ao cometer um ilícito administrativo, o agente público deverá ser responsabilizado funcionalmente e disciplinarmente, mediante um processo administrativo, em que seja assegurada a ampla defesa e o contraditório.

No desempenho de sua função, o agente público pode, basicamente, sujeitar-se aos seguintes tipos de responsabilidade: penal, civil, administrativa e pela prática de ato de improbidade administrativa.

A responsabilidade administrativa deve ser apurada pela própria Administração Pública mediante processo administrativo, sendo assegurados ao servidor a ampla defesa e o contraditório, nos termos do artigo 5. ${ }^{\circ}, \mathrm{LV}$, da Constituição Federal.

Comprovada a prática do ilícito administrativo pelo servidor, será aplicada a sanção correspondente. A responsabilidade administrativa do agente público decorre de sua submissão ao poder sancionatório disciplinar do Estado.

Em decorrência da responsabilidade administrativa, haverá íntima relação, quanto aos efeitos e repercussões, com a responsabilidade penal, a responsabilidade civil e a responsabilidade por atos de improbidade administrativa.

Depreende-se da regra do non bis in idem que ninguém poderá ser penalizado duas vezes pela mesma infração, pelo mesmo fato.

Como as responsabilidades podem acumular-se, pode haver acumulação das sanções, pois a cada tipo de responsabilidade é aplicada uma sanção. Um mesmo fato pode gerar quatro responsabilidades: civil, penal, administrativa e por atos de improbidade administrativa. Assim, entende-se que são quatro responsabilidades distintas que podem acumular-se, pois são independentes: civil, penal, administrativa e por ato de improbidade.

A independência das instâncias penal, civil, administrativa e de improbidade administrativa está consagrada na doutrina e na jurisprudência.

Ao lado disso, existe uma comunicação entre as diferentes esferas de responsabilidade, que, em alguns casos, incidem sobre o mesmo fato, ao qual, muitas vezes, cominam a mesma sanção, o que não lhes retira, entretanto, a autonomia e a independência e faz com que a responsabilização possa dar-se em uma, em algumas ou em todas as esferas.

Diante dessa realidade, o direito positivo contempla normas que buscam a compatibilização das instâncias, normas que se referem, fundamentalmente, à caracterização do ilícito, em cada uma das esferas, diante de um só fato.

As regras legais estabelecem, em geral, uma prevalência da esfera criminal sobre as demais, uma vez que a instrução probatória na ação penal é muito mais exigente. É preciso 
curvar-se ao que foi decidido, em termos de caracterização da conduta ilícita, em matéria criminal, ou seja, o que foi decidido na esfera criminal deve ser observado, de uma maneira geral, no âmbito civil, administrativo e também no âmbito da improbidade administrativa.

Essa harmonia e essa perfeita integração entre as instâncias são de suma importância para a garantia da tão almejada segurança jurídica, visto que o objetivo de todas as instâncias é verificar a existência da prática de um ato ou fato jurídico ilícito por parte do servidor público ou pelo cidadão.

O servidor público temporário não escapa à regra, sendo-lhe aplicado tudo o que foi estudado anteriormente quanto às responsabilidades civil, penal, administrativa e também por ato de improbidade administrativa, segundo a compatibilidade com a transitoriedade da contratação temporária.

Diante da realidade dos servidores públicos temporários, poder-se-ia até pensar em um "princípio de equiparação". De fato, a responsabilidade dos servidores públicos temporários e dos demais servidores públicos ("não temporários”) é igual, pois preenchem todos os requisitos: são servidores públicos e há responsabilidade. No entanto, como o vínculo temporário é reduzido, o processo administrativo disciplinar destinado a apurar a falta cometida também é reduzido. Por isso, o regime a que se chama "equiparável" necessita de adaptações em razão das especificações do vínculo especial a que se submete o servidor público.

O servidor público temporário responde pelos atos ilícitos em todas as esferas: penal, civil, administrativa e por atos de improbidade. Não é porque está transitoriamente na função que será eximido de responsabilidade ou protegido pelo excepcional interesse público; pelo contrário, por ser um servidor público, está sujeito aos ônus e bônus do serviço público, ou seja, aos direitos e deveres, com as devidas adequações ao servidor temporário.

Assim, a responsabilidade do servidor público deverá ser apurada mediante um processo administrativo disciplinar especial (ou sindicância ou processo sumário), adaptado à realidade dos servidores públicos temporários. Logo, deverá ser usado um instrumento processual pelo qual, respeitados o devido processo legal, o contraditório e a ampla defesa, chegar-se-á, se for o caso de responsabilização, à aplicação de uma medida sancionatória àquele servidor temporário que cometeu um ilícito.

Em virtude das peculiaridades desse servidor público temporário, buscou-se compatibilizar as suas características com o procedimento mais adequado para a apuração 
de suas faltas, garantindo a observância do devido processo legal, da ampla defesa e do contraditório durante todas as etapas do processo.

Aprofundou-se especificamente a responsabilidade do servidor público temporário pela prática de infrações disciplinares no âmbito administrativo.

Dessa forma, a regular apuração de eventuais infrações disciplinares cometidas por servidor temporário é medida imposta pelo interesse público, que reclama que o servidor faltoso, ainda que temporário, não seja pura e simplesmente "distratado", como se o desligamento se desse por "mera conveniência e oportunidade" da Administração.

A natureza precaríssima da contratação temporária exige apuração simplificada e célere de faltas disciplinares porventura praticadas em seu âmbito. A Lei n. ${ }^{\circ}$ 8.745/93 previu a utilização da sindicância com duração máxima de 30 (trinta) dias, que poderá, até mesmo, resultar na aplicação da pena de demissão. Não se concorda com a utilização da sindicância para aplicar uma penalidade de demissão ao servidor público temporário, sobretudo em razão da natureza precária do vínculo.

O mais adequado seria a previsão de um processo administrativo disciplinar adaptado, com prazos reduzidos, ou seja, um "miniprocesso administrativo disciplinar". Em razão de ausência de um rito próprio, demonstrou-se como seria desenvolvido o processo administrativo disciplinar na apuração de faltas do servidor público temporário, atendidos os preceitos legais e constitucionais e as particularidades do servidor público temporário.

Defende-se a aplicação aos servidores públicos temporários de um regime especial. Assim, também haveria um meio especial, peculiar de apuração de infrações assemelhado ao processo administrativo disciplinar, sempre se observando o devido processo legal, o contraditório e a ampla defesa em todos os casos de aplicação de penalidade, mesmo uma simples advertência.

Entende-se que deve ser instaurado um processo administrativo disciplinar contra o servidor temporário, ainda que ele não mantenha mais vínculo com a Administração Pública, considerando que a irregularidade administrativa causadora de lesão aos cofres públicos foi praticada à época do vínculo existente.

Mesmo o servidor temporário, e apesar da precariedade do vínculo mantido com a Administração, deverá responder pelos atos praticados na vigência do contrato, pois está sujeito aos princípios e regras do direito administrativo aplicável a todo e qualquer servidor. 
Ao lado da responsabilidade do servidor público temporário, nos casos de contratação temporária irregular, poderia ser incluída na legislação brasileira, a exemplo da legislação portuguesa, a responsabilidade civil, disciplinar e financeira da pessoa (dirigentes máximos dos órgãos ou serviços) que permitiu (celebrou) ou renovou a contratação (irregular). E ainda deve ser declarado nulo o contrato.

Como se pode constatar, o servidor público temporário responde civilmente, penalmente, administrativamente e por atos de improbidade pela prática de um ilícito, como qualquer outro servidor público (princípio de equiparação).

A Administração Pública visa atingir o interesse público, mas, para isso, precisa estruturar-se de forma adequada, devendo ser observadas regras e princípios no desenvolvimento da atividade administrativa.

Diante dessa realidade, todos os que integram a estrutura da Administração Pública devem respeitar e cumprir um conjunto de normas, sem as quais não será possível alcançar o tão almejado interesse público.

O regime disciplinar é um conjunto de normas que enumeram os deveres jurídicos a que se submetem os servidores públicos, definem a tramitação procedimental para apurar a responsabilidade pelo descumprimento dos deveres, por intermédio da aplicação de sanções disciplinares tipificadas na lei.

Pode-se dizer que o regime jurídico disciplinar seria o conjunto dos deveres, das normas disciplinares que devem ser respeitadas pelo servidor público. Deve haver a previsão legal das faltas (é o cometimento do ilícito administrativo) e das sanções disciplinares, devem existir procedimentos apuratórios das referidas faltas, com a garantia do direito de defesa, além de um controle interno, pela via recursal hierárquica, e de um controle externo, pelo exame da legalidade exercido pelo Poder Judiciário.

Estudou-se o regime disciplinar do servidor público temporário, de forma a conhecer seus direitos, deveres e proibições.

Para tanto, elegeu-se para a análise a Lei Federal n. ${ }^{\circ}$ 8.745, de 9 de dezembro de 1993, que dispõe sobre a contratação por tempo determinado para atender a necessidade temporária de excepcional interesse público dos órgãos da Administração Federal direta, das autarquias e das fundações públicas.

Por intermédio do poder disciplinar, a Administração Pública pode exercer uma espécie de controle sobre o desempenho e a conduta de seus subordinados, responsabilizando-os pelas faltas cometidas. 
Observa-se que o direito disciplinar ganhou importância, principalmente com o advento da Constituição Federal de 1988, dando ênfase ao devido processo legal, à ampla defesa e ao contraditório. Pode-se dizer que houve uma nova roupagem do direito disciplinar - principalmente com as novas garantias constitucionais -, muito diferente do que ocorria anteriormente.

Na verdade, o poder disciplinar é um dever da autoridade, conforme o artigo 143 do Estatuto dos Servidores Civis Federais (Lei n. ${ }^{\circ}$ 8.112/90)

Tomando como base o estatuto federal - a Lei n. ${ }^{\circ} 8.112 / 90$-, não se pode esquecer que o procedimento e as denominações na lei de alguns estados e municípios podem ser diferentes do estatuto federal, mas no geral a essência é a mesma.

A autoridade, ao tomar conhecimento de irregularidade no serviço público, tem o dever de determinar sua imediata apuração, visando o restabelecimento da regularidade e a continuidade do serviço público, sendo oportuno dizer que esse juízo preliminar que determina a instauração do processo deve estar forrado em motivo razoável, ou seja, deve haver um princípio de prova.

A autoridade deverá fazer uma análise prévia da denúncia, levantando todos os elementos acerca da suposta irregularidade, ponderando a necessidade e a utilidade de determinar a instauração da sede disciplinar (e da potencial responsabilização do servidor). Trata-se, portanto, de uma espécie de juízo (ou exame) de admissibilidade, de um juízo preliminar.

Assim, se a denúncia traz bons indícios apenas do cometimento do fato, sem indicar a autoria, a princípio, poder-se-ia cogitar a instauração de sindicância contraditória. De outro lado, se a notícia traz bons indícios tanto do fato quanto da autoria, haveria a justificativa para propor a instauração de processo administrativo disciplinar.

A Lei n. ${ }^{\circ}$ 8.112, de 12 de novembro de 1990, prevê três espécies de processos administrativos: o processo administrativo disciplinar stricto sensu (ou de rito ordinário, artigo 146), a sindicância disciplinar autônoma (artigo 145, II) e o processo disciplinar sumário (artigos 113 e 140).

O que determina a escolha entre processo administrativo disciplinar e sindicância são essencialmente dois fatores: a existência ou não de indicadores de autoria e a gravidade da infração denunciada. Se na denúncia constem indícios apenas sobre o fato, o ideal seria a instauração de uma sindicância. Se, por outro lado, na representação há indícios de autoria e de materialidade, caberia a instauração do processo administrativo disciplinar, se 
a infração for de natureza grave; caso contrário, se a infração for leve, pode-se instaurar a sindicância.

Já o procedimento sumário é aplicado nos seguintes casos: apuração de acumulação ilegal de cargos, de abandono de cargo e de inassiduidade habitual. Em todos os casos, é cabível a pena de demissão.

Do cometimento do ato ilícito, decorre a responsabilização do servidor. O processo administrativo é o instrumento legal necessário para responsabilizar administrativamente o servidor infrator por ato ou omissão associada diretamente ao exercício das atribuições do seu cargo ou, indiretamente, a pretexto de exercê-las.

Assim, o processo administrativo disciplinar é a sucessão formal de atos realizados pela Administração Pública, com o objetivo de apurar os fatos relacionados com a disciplina de seus servidores.

Em todos os procedimentos para a apuração de faltas de servidores públicos - devese fazer aqui uma ressalva, pois, na sindicância inquisitorial, não há contraditório, o que lhe retira a característica de processo, não podendo ser utilizada para a aplicação de nenhuma penalidade -, é obrigatória a observância do devido processo legal, do contraditório e da ampla defesa.

Assim, o devido processo legal exerce uma grande influência na vida e nos direitos dos indivíduos. É indispensável para assegurar todas as garantias e exigências inerentes ao processo e deve ser observado no processo de apuração das faltas disciplinares dos servidores públicos temporários na sua totalidade.

Como consequência da ampla defesa, há a presunção de inocência do servidor até o julgamento do processo, com o ônus de provar a responsabilização a cargo da administração.

A Súmula Vinculante n. ${ }^{\circ} 5$ do Supremo Tribunal Federal deve ser adequada ao caso concreto. Caberá à administração, diante da situação concreta, avaliar a necessidade ou não de profissional da área jurídica. O que se deve resguardar é o sagrado direito do acusado ao devido processo legal, à ampla defesa e ao contraditório.

A comissão deve ter como bandeira que as garantias da ampla defesa e do contraditório são a base da condução do processo, pois são os pilares da validade dos atos processuais, da decisão prolatada e de todo o processo em si, independentemente do rito (se processo administrativo disciplinar em rito ordinário ou sumário, ou se sindicância), sob pena de nulidade. 
Todos os meios de apuração de faltas admitidos (processo administrativo disciplinar, sindicância, processo sumário) devem estar cercados de todas as garantias processuais constitucionais, principalmente do devido processo legal, da ampla defesa e do contraditório, de forma a permitir a correta aplicação de sanções ou a absolvição dos acusados. Essas garantias devem abranger os acusados em geral, logo, incluem os servidores públicos temporários.

A Lei n. ${ }^{\circ} 8.112 / 90$, em seu artigo 127, enumera as seguintes penas administrativas: advertência, suspensão, demissão, cassação de aposentadoria ou de disponibilidade, destituição de cargo em comissão ou de função comissionada. Com base na Lei n. ${ }^{\circ}$ 8.745/93, aplicam-se aos temporários as penas de demissão, suspensão e advertência.

A Lei n. ${ }^{\circ}$ 8.112/90, em seus artigos 104 a 115, previu o chamado "direito de petição", inspirado no artigo $5^{\circ}$, XXXIII e XXXIV, da Constituição Federal, de grande utilidade para o servidor público na defesa de direito ou interesse legítimo perante a Administração Pública.

Engloba o direito de petição os seguintes institutos: o requerimento, o pedido de reconsideração e o recurso hierárquico (conforme artigos 105 a 107 da Lei n. ${ }^{o}$ 8.112/90).

O controle externo, para o processo administrativo, é uma garantia constitucional do livre ingresso no Poder Judiciário, mesmo antes de esgotada a via administrativa, visando a discussão de questão restrita à legalidade (artigo 5. ${ }^{\circ}, \mathrm{XXXV}$, da Constituição Federal).

É importante lembrar que o esgotamento da via administrativa não é pressuposto para o ingresso no Poder Judiciário. Além disso, cabe ao Judiciário apreciar a regularidade do procedimento, com base nos princípios da legalidade, do contraditório, da ampla defesa e do devido processo legal, sem adentrar o mérito administrativo.

Buscou-se demonstrar de forma clara o iter processual a ser seguido para a apuração das faltas disciplinares dos servidores públicos submetidos à Lei n. ${ }^{\circ}$ 8.112/90. A partir disso, considerando as peculiaridades do servidor público temporário, analisou-se a possibilidade de aplicação de tal procedimento no caso de cometimento de infrações disciplinares pelos servidores temporários em estudo, pretendendo-se estabelecer um verdadeiro regime jurídico disciplinar para os servidores públicos temporários.

Em que pesem a ausência de estabilidade e a precariedade do vínculo dos servidores temporários e a possibilidade de distrato a qualquer tempo, de acordo com a conveniência administrativa, caso a Administração tome conhecimento do cometimento de alguma falta disciplinar por parte do servidor temporário, será necessária a abertura de 
processo administrativo (sindicância, no dizer da Lei n. ${ }^{\circ}$ 8.745/93, ou processo sumário) para sua apuração.

Atualmente, o artigo 10 da Lei n. ${ }^{\circ}$ 8.745/93 esclarece que as infrações disciplinares atribuídas aos servidores temporários serão apuradas mediante sindicância, concluída no prazo de até trinta dias e assegurada a ampla defesa. Ocorre que a Lei n. ${ }^{\circ}$ 8.745/93 não aplica aos servidores temporários o rito estabelecido na Lei n. ${ }^{\circ} 8.112 / 90$ para os servidores submetidos ao regime estatutário.

Assim, o artigo 11 da Lei n. ${ }^{\circ} 8.745 / 93$ estabelece que se aplicam ao pessoal contratado temporariamente os artigos da Lei n. ${ }^{\circ}$ 8.112/90, que tratam, na matéria disciplinar, de algumas irregularidades, responsabilidade, penalidades e prescrição.

Observa-se que não há referência ao rito processual previsto nos artigos 143 a 182 da Lei n. ${ }^{\circ}$ 8.112/90, mas curiosamente se aplica o artigo 140 da Lei n. ${ }^{\circ} 8.112 / 90$ aos servidores temporários em caso de apuração de abandono de cargo ou de inassiduidade habitual, quando é adotado o procedimento sumário constante do artigo 133 da Lei n. ${ }^{\circ}$ $8.112 / 90$.

Isso significa que, para a apuração e a responsabilização dos ilícitos administrativos cometidos pelos servidores temporários, não há obrigação de seguir o rito processual estabelecido na Lei n. ${ }^{\circ}$ 8.112/90, em razão das características de tais servidores, mas há, sim, necessidade de serem respeitadas as cláusulas do devido processo legal (do artigo 5. , LIV, da Constituição Federal), da ampla defesa e do contraditório (do artigo 5. ${ }^{\circ}, \mathrm{LV}$, da Constituição Federal c/c artigo 10 da Lei n. ${ }^{\circ}$ 8.745/93).

Os servidores temporários estão sujeitos aos procedimentos de apuração de abandono de cargo ou de inassiduidade habitual, quando é adotado o procedimento sumário, por força do artigo 11 da Lei n. ${ }^{\circ}$ 8.745/93.

É importante observar que o servidor público temporário ocupa função. Então, especificamente para o servidor público temporário, poderíamos dizer que o procedimento sumário é utilizado para os casos de abandono de função ou de inassiduidade habitual. Isso porque o artigo 11 da Lei n. ${ }^{\circ} 8.745 / 93$ estende a aplicação dos artigos 136 a 140 da Lei n. ${ }^{\circ}$ 8.112/90 aos servidores públicos temporários.

Entende-se que, na acumulação ilegal de cargos, empregos ou funções, os servidores temporários também estariam sujeitos ao procedimento sumário, pois ocupam funções, além disso, por força do artigo 11 da Lei n. ${ }^{\circ}$ 8.745/93 aplica-se aos temporários o artigo 118 a 120 da Lei n. 8.112/90. 
Objetivou-se apresentar o caminho razoável a ser seguido, considerando que a realidade dos servidores temporários é muito comum na Administração Pública brasileira e precisa haver um procedimento para o caso do regime disciplinar dos servidores públicos temporários.

Dessa forma, de acordo com a Lei Federal n. ${ }^{\circ}$ 8.745/93, as faltas disciplinares dos servidores públicos temporários são apuradas mediante sindicância, concluída no prazo de trinta dias, que poderá ter como resultado uma advertência, uma suspensão ou uma demissão, sempre observada a ampla defesa e o contraditório.

Assim, diante dessa realidade, observa-se que a sindicância de que trata a Lei n. ${ }^{\circ}$ 8.745/93 é uma sindicância sui generis, pois permite a aplicação da penalidade de suspensão por mais de trinta dias e a demissão, o que, segundo a essência da Lei n. ${ }^{\circ}$ 8.112/90, não seria possível pela apuração de sindicância, somente por processo administrativo disciplinar.

Detectada a ocorrência de falta disciplinar cometida por servidor temporário, impõe-se sua apuração.

Dessa forma, à semelhança do rito do processo administrativo, adotam-se as seguintes fases para a apuração de faltas dos servidores temporários: instauração, inquérito administrativo (que compreende instrução, defesa, relatório) e julgamento.

Basicamente, é utilizado o mesmo rito processual do processo administrativo disciplinar, com algumas variações de prazo e de número de testemunhas, e com perícias de pouca complexidade.

Entende-se razoável o prazo de 30 dias para a conclusão dos trabalhos, pois se trata de um contrato por tempo determinado, para atendimento de necessidade temporária de excepcional interesse público. São ou devem ser situações de curto prazo, então não há por que estender as apurações por mais de trinta dias, mas sempre se deve respeitar o contraditório e a ampla defesa.

Defende-se que cabe tanto o pedido de reconsideração quanto o recurso hierárquico da decisão proferida pela autoridade julgadora, em razão do princípio da ampla defesa. $\mathrm{O}$ prazo de interposição é de dez dias (redução do prazo) a partir da ciência da decisão que se quer reformar.

Já o pedido de revisão não é compatível com as características do servidor temporário, que não possui estabilidade, foi contratado por tempo determinado para atender a necessidade temporária de excepcional interesse público, exercendo função. 
O afastamento preventivo do acusado não é medida compatível com a característica do servidor público temporário.

Diante dessa realidade, há sem dúvida um "princípio de equiparação". O servidor temporário, contratado por tempo determinado para atender a necessidade temporária de excepcional interesse público, é uma espécie de servidor público do gênero agente público. Ficando comprovado que a responsabilidade dos servidores públicos temporários e dos demais servidores públicos ("não temporários") é igual, ou seja, que ambos respondem, deve haver um processo administrativo disciplinar para apuração das faltas, estabelecido por intermédio de um regime jurídico disciplinar a ser observado.

Daí a necessidade de construir, com base nas características próprias dessa espécie de servidor público, um regime adaptado às especificações do vínculo especial a que se submete o servidor público temporário.

Estar-se-á diante de um miniprocesso disciplinar ou de um processo disciplinar especial ou de uma minissindicância ou sindicância especial, sui generis. 


\section{REFERÊNCIAS}

ABREU, José. O negócio jurídico e sua teoria geral. São Paulo: Saraiva, 1988.

ALEXY, Robert. Teoría de los derechos fundamentales. Madrid: Centro de Estudios Políticos y Constitucionales, 2001.

ALVES, Léo da Silva. Processo disciplinar em 50 questões. Brasília, DF: Brasília Jurídica, 2002.

ALVIM, Angélica Arruda. Princípios constitucionais do processo. Revista de Processo, São Paulo, v. 19, n. 74, p. 20-39, abr./jun. 1994.

ANASTASIA, Antônio Augusto Junho. Regime jurídico único do servidor público. Belo Horizonte: Del Rey, 1990.

ANTUNES, Vera Lúcia Santos. O contrato de trabalho na administração pública: evolução, reflexos e tendências para o emprego público. Coimbra: Coimbra Editora, 2010.

ARAÚJO, Edmir Netto de. Os princípios administrativos na Constituição de 1988. Revista da Procuradoria Geral do Estado de São Paulo, São Paulo, n. 34, p. 133-142, dez. 1990.

. Do negócio jurídico administrativo. São Paulo: Revista dos Tribunais, 1992.

. O ilícito administrativo e seu processo. São Paulo: Revista dos Tribunais, 1994.

Convalidação do ato administrativo. São Paulo: LTR, 1999.

. Curso de direito administrativo. 6. ed. São Paulo: Saraiva, 2014.

ARAÚJO, Florivaldo Dutra de. Requisitos constitucionais para a contratação temporária de servidores públicos. In: FORTINI, Cristiana (Org.). Servidor público: estudos em homenagem ao professor Pedro Paulo de Almeida Dutra. Belo Horizonte: Fórum, 2009. p. 119-127.

AUBY, Jean-Marie; DUCOS-ADER, Robert. Droit administratif. 7. éd. Paris: Dalloz, 1986.

AUBY, Jean-Marie et al. Droit de la fonction publique. 7. éd. Paris: Dalloz, 2012.

BACELLAR FILHO, Romeu Felipe. Princípios constitucionais do processo administrativo disciplinar. São Paulo: Max Limonad, 1998.

. Processo administrativo disciplinar. 4 ed. São Paulo: Saraiva, 2013.

BARATA, Ana Maria Rodrigues. A inconstitucionalidade da Lei Complementar n. ${ }^{\circ}$ 040, de 25 de junho de 2002, que transfere servidores temporários para o quadro suplementar da Administração Pública estadual. Boletim Informativo da Defesa Comunitária e da Cidadania do Ministério Público do Estado do Pará, Belém, n. 12. v. 7, p. 33-48, 2003. 
. A Súmula Vinculante n. $^{\circ} 5$ do Supremo Tribunal Federal e a defesa técnica por advogado no processo administrativo disciplinar. Revista do Ministério Público do Estado do Pará, Belém, ano III, v. 1, p. 63-70, dez. 2008.

BARBOZA, Márcia Noll. Definição de improbidade administrativa. In: BARBOZA, Márcia Noll (Coord.). Cem perguntas e respostas sobre improbidade administrativa: incidência e aplicação da Lei n. 8.429/1992. Brasília, DF: Escola Superior do Ministério Público da União, 2008. p. 13-17.

BARROS, Suzana de Toledo. O princípio da proporcionalidade e o controle de constitucionalidade das leis restritivas de direitos fundamentais. 2. ed. Brasília, DF: Brasília Jurídica, 2000.

BARROS JÚNIOR, Carlos S. de. Do poder disciplinar na administração pública. São Paulo: Revista dos Tribunais, 1972.

BASTOS, Aline Maria Dias. Conceitos jurídicos indeterminados: discricionariedade ou vinculação? 2002. 216 f. Dissertação (Mestrado em Direito) - Faculdade de Direito, Universidade de São Paulo, São Paulo, 2002.

. A Lei de Greve aplicada ao servidor público. In: DI PIETRO, Maria Sylvia Zanella (Org.). Direito privado administrativo. São Paulo: Atlas, 2013. p. 50-64.

BASTOS, Celso Ribeiro; MARTINS, Ives Gandra. Comentários à Constituição do Brasil. São Paulo: Saraiva, 1992, v. 3.

BITENCOURT NETO, Eurico. Improbidade administrativa e violação de princípios. Belo Horizonte: Del Rey, 2005.

BONAVIDES, Paulo. Curso de direito constitucional. 5. ed. São Paulo: Malheiros, 1994.

BRAZ, Petrônio. O servidor público na reforma administrativa. São Paulo: LED - Editora de Direito, 1998.

CAETANO, Marcello. Do poder disciplinar no direito administrativo português. Coimbra: Imprensa da Universidade, 1932.

Manual de direito administrativo. 9. ed. Coimbra: Almedina, 1983, v. 2.

CANDIOTA, Telmo. Servidor público: contratação temporária (regime jurídico previsto no art. 37, IX, da CF). Revista Trimestral de Direito Público, São Paulo, n. 6, p. 169-174, abr./jun. 1994.

CARRAZZA, Roque Antônio. Curso de direito constitucional tributário. 11. ed. São Paulo: Malheiros, 1998.

CARVALHO, Antônio Carlos Alencar. Manual de processo administrativo disciplinar e sindicância à luz da jurisprudência dos Tribunais e da casuística da Administração Pública. 3. ed. Belo Horizonte: Fórum, 2012. 
CARVALHO FILHO, José dos Santos. Manual de direito administrativo. 25. ed. São Paulo: Atlas, 2012a.

Terceirização no setor público: encontros e desencontros. In: FORTINI, Cristiana (Org.). Terceirização na Administração: estudos em homenagem ao professor Pedro Paulo de Almeida Dutra. 2. ed. Belo Horizonte: Fórum, 2012b. p. 47-70.

CASTRO, Carlos Borges de. Regime jurídico da CLT no funcionalismo. São Paulo: Saraiva, 1981.

CAUPERS, João. Introdução ao direito administrativo. 10 ed. Lisboa: Âncora, 2009.

CAVALCANTE, Jouberto de Quadros Pessoa; JORGE NETO, Francisco Ferreira. $O$ empregado público. São Paulo: LTR, 2002.

CAVALCANTI, Themístocles Brandão. O funcionário público e o seu regime jurídico. 2. ed. Rio de Janeiro: Freitas Bastos, 1946.

Tratado de direito administrativo. 3. ed. Rio de Janeiro: Freitas Bastos, 1956, v. 4.

1966.

Direito e processo disciplinar. 2. ed. Rio de Janeiro: Fundação Getúlio Vargas,

CINTRA, Antônio Carlos de Araújo. Motivo e motivação do ato administrativo. São Paulo: Revista dos Tribunais, 1979.

CINTRA, Antônio Carlos de Araújo; GRINOVER, Ada Pellegrini; DINAMARCO, Cândido Rangel. Teoria geral do processo. 10. ed. São Paulo: Malheiros, 1994.

COSTA, José Armando da. Direito administrativo disciplinar. 2. ed. Rio de Janeiro: Forense; São Paulo: Método, 2009.

$\overline{\text { Forense, }} 2010$.

Processo administrativo disciplinar: teoria e prática. 6. ed. Rio de Janeiro:

CRETELlA JÚNIOR, José. Comentários à Constituição Brasileira de 1988. 2. ed. Rio de Janeiro: Forense Universitária, 1992, v. 4. . O Estado e a obrigação de indenizar. Rio de Janeiro: Forense, 1998.

. Tratado de direito administrativo. 2. ed. Rio de Janeiro: Forense, 2002, v. 2.

. Tratado de direito administrativo. 2. ed. Rio de Janeiro: Forense, 2005, v. 4.

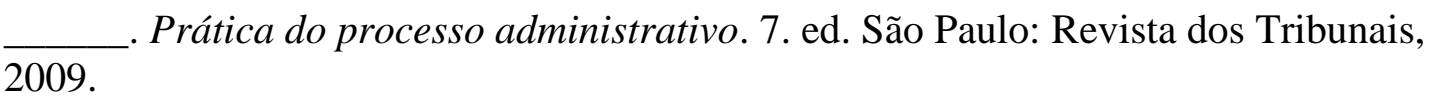

DALLARI, Adilson Abreu. Regime constitucional dos servidores públicos. 2. ed. São Paulo: Revista dos Tribunais, 1990. 
DICIONÁRIO eletrônico Houaiss da língua portuguesa. [S.1.]: Objetiva, 2009. 1 CD-ROM.

DINAMARCO, Cândido Rangel. O princípio do contraditório. Revista da Procuradoria Geral do Estado de São Paulo, São Paulo, n. 19, p. 21-37, dez. 1981/dez. 1982.

Fundamentos do processo civil moderno. 6. ed. São Paulo: Malheiros, 2010, t. I.

DINIZ, Maria Helena. Curso de direito civil brasileiro. 29. ed. São Paulo: Saraiva, 2012, V. 1 .

DI PIETRO, Maria Sylvia Zanella. Discricionariedade administrativa na Constituição de 1988. 2. ed. São Paulo: Atlas, 2001.

Direito administrativo. 26. ed. São Paulo: Atlas, 2013.

DUGUIT, Léon. Traité de droit constitutionnel. 3 éd. Paris: E. de Boccard, 1930, v. 3.

ESCOLA, Héctor Jorge. El interés público como fundamento del derecho administrativo. Buenos Aires: Depalma, 1989.

ESTORNINHO, Maria João. A fuga para o direito privado: contributo para o estudo da actividade de direito privado da Administração Pública. 2. reimpr. Coimbra: Almedina, 2009.

FERNANDES, Flávio Sátiro. Improbidade administrativa. Revista de Direito Administrativo, Rio de Janeiro, n. 210, p. 171-181, out./dez. 1997.

FIGUEIREDO, Lúcia Valle. Curso de direito administrativo. 9. ed. São Paulo: Malheiros, 2008.

FIGUEIREDO, Marcelo. Probidade administrativa: comentários à Lei 8.429/82 e legislação complementar. São Paulo: Malheiros, 2009.

FORTINI, Cristiana; PIEVE, Flávia Cristina Mendonça Faria da. As terceirizações e as contratações temporárias realizadas pela Administração Pública: distinção entre as duas figuras e o impacto na LRF. In: FORTINI, Cristiana (Org.). Terceirização na Administração: estudos em homenagem ao professor Pedro Paulo de Almeida Dutra. 2. ed. Belo Horizonte: Fórum, 2012. p. 11-30.

FRANCO SOBRINHO, Manoel de Oliveira. Do princípio da moralidade administrativa. Revista de Direito Administrativo, Rio de Janeiro, n. 190, p. 247-252, out./dez. 1992.

GARCIA, Emerson; ALVES, Rogério Pacheco. Improbidade administrativa. 4. ed. Rio de Janeiro: Lumen Juris, 2008.

GARCIA, Mônica Nicida. Responsabilidade do agente público. 2. ed. Belo Horizonte: Fórum, 2007. 
GARCÍA DE ENTERRÍA, Eduardo; FERNÁNDEZ, Tomás-Ramón. Curso de derecho administrativo. 4. ed. Madrid: Civitas, 1995, v. 2.

GASPARINI, Diogenes. Direito administrativo. 17. ed. São Paulo: Saraiva, 2012.

GONÇALVES, Carlos Roberto. Direito civil brasileiro. 9. ed. São Paulo: Saraiva, 2011, v. 1.

GONOD, Pascale; MELLERAY, Fabrice; YOLKA, Philippe. Traité de droit administratif. Paris: Dalloz, 2011, t. II.

GORDILLO, Agustín. Princípios gerais de direito público. Tradução de Marco Aurélio Greco. São Paulo: Revista dos Tribunais, 1977.

GRAU, Eros Roberto. A ordem econômica na Constituição de 1988: interpretação e crítica. 4. ed. São Paulo: Malheiros, 1998.

GRINOVER, Ada Pellegrini. Novas tendências do direito processual de acordo com a Constituição de 1988. Rio de Janeiro: Forense Universitária, 1990.

Do direito de defesa em inquérito administrativo. Revista de Direito Administrativo, Rio de Janeiro, n. 183, p. 9-18, jan./mar. 1991.

GUIMARÃES, Francisco Xavier da Silva. Regime disciplinar do servidor público civil da União. 2. ed. Rio de Janeiro: Forense, 2006.

HAURIOU, Maurice. Précis de droit administratif et de droit public. Paris: Sirey, 1927.

JÈZE, Gaston. Principios generales del derecho administrativo. Buenos Aires: Depalma, 1949, v. 3.

LESSA, Sebastião José. Do processo administrativo disciplinar e da sindicância: doutrina, jurisprudência e prática. 5. ed. Brasília, DF: Brasília Jurídica, 2009.

LINARES, Juan Francisco. Poder discrecional administrativo. Buenos Aires: AbeledoPerrot, 1958.

MADEIRA, Vinícius de Carvalho. Lições de processo disciplinar. São Paulo: Fortium, 2008.

MAIA, Márcio Barbosa; QUEIROZ, Ronaldo Pinheiro de. O regime jurídico do concurso público e o seu controle jurisdicional. São Paulo: Saraiva, 2007.

MARQUES, Silvio Antonio. Improbidade administrativa. São Paulo: Saraiva, 2010.

MARQUES NETO, Floriano Peixoto de Azevedo. A republicização do Estado e os interesses públicos. 1999. 340 f. Tese (Doutorado em Direito) - Faculdade de Direito, Universidade de São Paulo, São Paulo, 1999. 
MARTINEZ, José Maria de S. O servidor temporário e seu regime jurídico. [200-?]. Disponível em:

<http://uj.novaprolink.com.br/doutrina/344/o_servidor_temporario_e_seu_regime_juridico >. Acesso em: 19 ago. 2011.

MARTINS, Sergio Pinto. Direito do trabalho. 28. ed. São Paulo: Atlas, 2012.

MARTINS JÚNIOR, Wallace Paiva. Probidade administrativa. 4. ed. São Paulo: Saraiva, 2009.

MEDAUAR, Odete. A processualidade no direito administrativo. São Paulo: Revista dos Tribunais, 1993.

Direito administrativo moderno. 15. ed. São Paulo: Revista dos Tribunais, 2011.

MEDEIROS, Adriane de Araujo; TIEMANN, Marisa; ANDONINI, Neli; MOREIRA, Rosana Santos. Estudo sobre o art. 37 da Constituição Federal. Revista de Direito Administrativo Aplicado, Curitiba, v. 1. n. 1, p. 423-429, 1994.

MEIRELLES, Hely Lopes. Direito administrativo brasileiro. 38. ed. São Paulo: Malheiros, 2012.

MELLERAY, Fabrice. Droit de la fonction publique. 3 éd. Paris: Economica, 2013.

MELLO, Celso Antônio Bandeira de. Apontamentos sobre os agentes e órgãos públicos. São Paulo: Revista dos Tribunais, 1987.

. Regime constitucional dos servidores da administração direta e indireta. 2. ed. São Paulo: Revista dos Tribunais, 1991.

Curso de direito administrativo. 30. ed. São Paulo: Malheiros, 2013.

MELLO, Oswaldo Aranha Bandeira de. Relação jurídica entre o Estado e os seus servidores. São Paulo: Prefeitura do Município de São Paulo, 1945.

Teoria dos servidores públicos. Revista de Direito Público, São Paulo, v. 1, n. 1, p. 40-53, jul./set. 1967.

MELO, Frederico Jorge Gouveia de. Admissão de pessoal no serviço público: procedimentos, restrições e controles (de acordo com a Lei de Responsabilidade Fiscal). 2. ed. Belo Horizonte: Fórum, 2009.

MELO, José Augusto de Carvalho e. Extranumerário. Revista de Direito Administrativo, Rio de Janeiro, v. 1, p. 347-358, jan. 1945.

MENDONÇA, Francisco Maria de Souza Furtado de. Excerto de direito administrativo pátrio. [S.1.: s.n.], 1865.

MONTEIRO, Washington de Barros; PINTO, Ana Cristina de Barros Monteiro França. Curso de direito civil. 44. ed. São Paulo: Saraiva, 2012, v. 1. 
MORAES FILHO, Evaristo de; MORAES, Antonio Carlos Flores de. Introdução ao direito do trabalho. 6. ed. São Paulo: LTR, 1993.

MORAES FILHO, Marco Antônio Praxedes de. Súmula Vinculante n. 5 do Supremo Tribunal Federal e o sistema processual administrativo punitivo: um retrospecto na interpretação contemporânea do princípio do devido processo legal e na evolução dos desdobramentos do princípio da ampla defesa. In: NOHARA, Irene Patrícia; MORAES FILHO, Marco Antônio Praxedes de (Org.). Processo administrativo: temas polêmicos da Lei n. ${ }^{\circ}$ 9.784/00. São Paulo: Atlas, 2011. p. 158-183.

MOREIRA NETO, Diogo de Figueiredo. Regime jurídico único dos servidores públicos na Constituição de 1988. Rio de Janeiro: Lumen Juris, 1990.

. Moralidade administrativa: do conceito à efetivação. Revista de Direito Administrativo, Rio de Janeiro, n. 190, p. 1-44, out./dez. 1992.

Curso de direito administrativo. 15. ed. Rio de Janeiro: Forense, 2009.

MOTTA, Fabrício. Contratação temporária por excepcional interesse público. In: DI PIETRO, Maria Sylvia Zanella; MOTTA, Fabrício; FERRAZ, Luciano de Araújo. Servidores públicos na Constituição de 1988. São Paulo: Atlas, 2011. p. 69-74.

MOURA, Paulo Veiga e. Estatuto Disciplinar dos Trabalhadores da Administração Pública anotado. 2. ed. Coimbra: Coimbra Editora, 2011.

MOURA, Paulo Veiga e; ARRIMAR, Cátia. Os novos regimes de vinculação, de carreiras e de remunerações dos trabalhadores da administração pública: comentário à Lei n. ${ }^{\circ} 12$ A/2008, de 27 de fevereiro. 2. ed. Coimbra: Coimbra Editora, 2010.

MUKAI, Toshio. Administração pública na Constituição de 1988. 2. ed. São Paulo: Saraiva, 1989.

. Da aplicabilidade do princípio da moralidade administrativa e do seu controle jurisdicional. Boletim de Direito Administrativo, São Paulo, v. 10, n. 2, p. 86-90, fev. 1994.

NASCIMENTO, Amauri Mascaro. Curso de direito do trabalho. 25. ed. São Paulo: Saraiva, 2010.

NETTO, Luísa Cristina Pinto e. A contratualização da função pública. Belo Horizonte: Del Rey, 2005.

NEVES, Ana Fernanda. O posto de trabalho e a mobilidade concorrencial como instrumentos jurídicos de tutela dos direitos do trabalhador público. In: FONSECA, Isabel Celeste M. (Coord.). Trabalho em funções públicas em tempos de crise: que direito(s)? Braga: Sindicato dos Trabalhadores em Funções Públicas e Sociais do Norte, 2013. Atas das I Jornadas de Direito do Emprego Público. p. 11-34.

NEVES, Sergio Luiz Barbosa. Regime jurídico único e os servidores públicos. Rio de Janeiro: Lumen Juris, 1991. 
NOHARA, Irene Patrícia. Direito administrativo. 3. ed. São Paulo: Atlas, 2013.

OCTAVIANO, Ernomar; GONZALES, Átila José. Sindicância e processo administrativo. 11. ed. São Paulo: Livraria e Editora Universitária de Direito, 2009.

OLIVEIRA, José Roberto Pimenta. Os princípios da razoabilidade e da proporcionalidade no direito administrativo brasileiro. São Paulo: Malheiros, 2006.

Improbidade administrativa e sua autonomia constitucional. Belo Horizonte:

Fórum, 2009.

OLIVEIRA, Regis Fernandes de. Servidores públicos. 2 ed. São Paulo: Malheiros, 2008.

PEREIRA, Caio Mário da Silva. Instituições de direito civil. 23. ed. Rio de Janeiro:

Forense, 2012, v. 1.

PONTES, Helenilson Cunha. O princípio da proporcionalidade e o direito tributário. São Paulo: Dialética, 2000.

RAMALHO, Maria do Rosário Palma; BRITO, Pedro Madeira. Regime do contrato de trabalho em funções públicas. Coimbra: Almedina, 2009.

RIGOLIN, Ivan Barbosa. O servidor público na Constituição de 1988. São Paulo: Saraiva, 1989.

ROCHA, Cármen Lúcia Antunes. Princípios constitucionais da Administração Pública. Belo Horizonte: Del Rey, 1994.

Princípios constitucionais dos servidores públicos. São Paulo: Saraiva, 1999.

ROCHA, João Batista de Oliveira. O regime jurídico especial do servidor público. Revista de Direito Público, São Paulo, ano 7, n. 37-38, p. 129-133, jan./jun. 1976.

ROMITA, Arion Sayão. Regime jurídico dos servidores públicos civis: aspectos trabalhistas e previdenciários. São Paulo: LTR, 1992.

ROTHENBURG, Walter Claudius. Princípios constitucionais. Porto Alegre: Sergio Antonio Fabris, 1999.

SANTOS, Alvacir Correa dos. Contratação temporária na Administração Pública. Curitiba: Gênesis, 1996.

SILVA, José Afonso da. Aplicabilidade das normas constitucionais. 7. ed. São Paulo: Malheiros, 2008.

Curso de direito constitucional positivo. 32. ed. São Paulo: Malheiros, 2009.

SOARES, Rogério Guilherme Ehrhardt. Direito administrativo. Coimbra: [s.n.], 1978. 
STOCO, Rui. Responsabilidade civil e sua interpretação jurisprudencial. 4. ed. São Paulo: Revista dos Tribunais, 1999.

SUNDFELD, Carlos Ari. Fundamentos de direito público. 3. ed. São Paulo: Malheiros, 1997.

TEIXEIRA, Marcos Salles. Anotações sobre processo administrativo disciplinar. Agosto 2014. Disponível em: <http://www.cgu.gov.br/Publicacoes/atividadedisciplinar/arquivos/rfb-anotacoessobrepad.pdf>. Acesso em: 24 out. 2014.

TUCCI, Rogério Lauria; CRUZ E TUCCI, José Rogério. Constituição de 1988 e processo: regramentos e garantias constitucionais do processo. São Paulo: Saraiva, 1989.

VASCONCELOS, André Prado de. Contratação por tempo determinado para atender à necessidade temporária de excepcional interesse público com adoção de parcela das disposições do regime estatutário: regime especial ou burla à norma constitucional insculpida no art. 37, inciso II, da Constituição Federal de 1988. Revista do Tribunal Regional Federal da 1. ${ }^{a}$ Região, Brasília, DF, v. 15, n. 2, p. 48-84, fev. 2003.

VIEIRA, Judivan Juvenal. Processo administrativo disciplinar. São Paulo: IOB Thomson, 2005.

VIEIRA, Raphael Diógenes Serafim. Servidor público temporário: natureza jurídica, regime, contratação irregular e a (não) incidência do princípio primazia da realidade de fato sobre as formas. Viçosa: UFV, 2007.

VITTA, Heraldo Garcia. A sanção no direito administrativo. São Paulo: Malheiros, 2003.

WALD, Arnoldo. Direito civil. 11. ed. São Paulo: Saraiva, 2009, v. 1. 


\section{BIBLIOGRAFIA CONSULTADA}

ALESSI, Renato. Sistema istituzionale del diritto amministrativo italiano. Milano: Dott Antonino Giuffrè, 1953.

ALVES, Léo da Silva. As teses de defesa na sindicância e no processo disciplinar. Brasília, DF: Brasília Jurídica, 1999.

Prática de processo disciplinar. Brasília, DF: Brasília Jurídica, 2001.

. Processo disciplinar passo a passo. Brasília, DF: Brasília Jurídica, 2002.

A prova no processo disciplinar. Rio de Janeiro: Lumen Juris, 2003.

ANGERAMI, Alberto; PENTEADO FILHO, Nestor Sampaio. Direito administrativo disciplinar: comentários à Lei Orgânica da Polícia do Estado de São Paulo. Campinas, SP: Millennium, 2004.

ANJOS, Luís Henrique Martins dos. Elementos para uma nova categorização dos agentes públicos brasileiros em face do Estado de Direito Democrático. Revista da AGU, Brasília, DF, v. 4, n. 8, p. 79-91, dez. 2005.

ARAÚJO, Edmir Netto de. Responsabilidade do Estado por ato jurisdicional. São Paulo: Revista dos Tribunais, 1981.

Contrato administrativo. São Paulo: Revista dos Tribunais, 1987.

ARAÚJO, Florivaldo Dutra de. Motivação e controle do ato administrativo. Belo Horizonte: Del Rey, 1992.

AZEVEDO, Antonio Junqueira de. Negócio jurídico: existência, validade e eficácia. São Paulo: Saraiva, 1986.

BACIGALUPO, Mariano. La discrecionalidad administrativa: (estructura normativa, control judicial y límites constitucionales de su atribución). Madrid: Marcial Pons, 1997.

BARATA, Ana Maria Rodrigues. O princípio da razoabilidade como limite da discricionariedade administrativa. 2001. 147 f. Dissertação (Mestrado em Direito) Universidade Federal do Pará, Belém, 2001.

. A “estabilidade" dos servidores temporários. Revista de Direito - FAP. Belém, v.

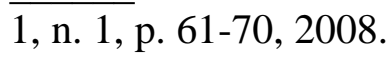

BARROS, Wellington Pacheco. Curso de processo administrativo. Porto Alegre: Livraria do Advogado, 2005. 
BARROS FILHO, Mário Leite de. Direito administrativo disciplinar da Polícia:"via rápida" material e processual. São Paulo: Edipro, 2003.

BENOIT, Francis-Paul. Le droit administratiffrançais. Paris: Dalloz, 1968.

BIRNFELD, Osny Jaeger. Processo administrativo disciplinar. Canoas, RS: IPUC, 1977.

BORGES, Alice Gonzalez. Interesse público: um conceito a determinar. Revista de Direito Administrativo, Rio de Janeiro, n. 205, p. 109-116, jul./set. 1996.

BRAZ, Petrônio. Atos administrativos. São Paulo: LED - Editora de Direito, 1997.

BRUNO, Reinaldo Moreira; DEL OLMO, Manolo. Servidor público: doutrina e jurisprudência. Belo Horizonte: Del Rey, 2006.

BUENO, Cassio Scarpinella. Inafastabilidade do controle judicial da Administração. In: SUNDFELD, Carlos Ari; BUENO, Cassio Scarpinella (Coord.). Direito processual público: a Fazenda Pública em juízo. São Paulo: Sociedade Brasileira de Direito Público; Malheiros, 2000. p. 238-248.

BUENO, Vera Cristina Caspari Monteiro Scarpinella. As leis de procedimento administrativo: uma leitura operacional do princípio constitucional da eficiência. In: SUNDFELD, Carlos Ari; MUÑOZ, Guillermo Andrés (Coord.). As leis de processo administrativo. São Paulo: Sociedade Brasileira de Direito Público; Malheiros, 2000. p. 342-363.

CAMMAROSANO, Márcio. Provimento de cargos públicos no direito brasileiro. São Paulo: Revista dos Tribunais, 1984.

CAMPOS, Francisco. Direito administrativo. São Paulo: Livraria Freitas Bastos, 1958.

CANOTILHO, José Joaquim Gomes. Direito constitucional e teoria da Constituição. 3. ed. Coimbra: Almedina, 1999.

CARVALHO, Anísio Asterio Contreiras. Processo administrativo disciplinar. Rio de Janeiro: Freitas Bastos, 1995.

CARVALHO, Raquel. Comentário ao Estatuto Disciplinar dos trabalhadores que exercem funções públicas. Lisboa: Universidade Católica Editora, 2012.

CARVALHO FILHO, José dos Santos. Processo administrativo federal. Rio de Janeiro: Lumen Juris, 2001.

. Terceirização no setor público: encontros e desencontros. Fórum de Contratação e Gestão Pública, Belo Horizonte, ano 8, n. 89, p. 60-71, maio 2009.

COELHO, Fábio Ulhoa. Curso de direito civil. 5. ed. São Paulo: Saraiva, 2012, v. 1.

COELHO, Rogério Viola. A relação de trabalho com o Estado: uma abordagem crítica da doutrina administrativa da relação de função pública. São Paulo: LTR, 1994. 
COGAN, Arthur. Crimes contra a Administração Pública. São Paulo: Juarez Oliveira, 2003.

CORREIA, José Manuel Sérvulo. Noções de direito administrativo. Lisboa: Danúbio, 1982, v. 1.

COSTA, Alexandre Araújo. O princípio da razoabilidade na jurisprudência do Supremo Tribunal Federal. 1999. 372 f. Dissertação (Mestrado em Direito) - Universidade de Brasília, Brasília, DF, 1999.

COSTA, José Armando da. Controle judicial do processo disciplinar. Brasília, DF: Brasília Jurídica, 2002.

. Incidência aparente de infrações disciplinares. Belo Horizonte: Fórum, 2004.

_. Prescrição disciplinar. Belo Horizonte: Fórum, 2006.

2008 .

Direito disciplinar: temas substantivos e processuais. Belo Horizonte: Fórum,

COSTA, Nelson Nery. Processo administrativo e suas espécies. Rio de Janeiro: Forense, 2005.

CRETELLA JÚNIOR, José. Do ilícito administrativo. Revista da Procuradoria Geral do Estado de São Paulo, n. 4, p. 27-49, 1973/74.

DEZAN, Sandro Lucio. Ilícito administrativo disciplinar. Curitiba: Juruá, 2009.

DINAMARCO, Cândido Rangel. A instrumentalidade do processo. 5. ed. São Paulo: Malheiros, 1996.

DINIZ, Paulo de Matos Ferreira. Lei $n^{\circ}{ }^{8}$ 8.112: regime jurídico único. 6. ed. Brasília, DF: Brasília Jurídica, 2001.

DI PIETRO, Maria Sylvia Zanella. Servidores temporários - Lei n. 500/1974: inclusão no regime próprio de Previdência do servidor público. Revista da Procuradoria Geral do Estado de São Paulo, São Paulo, n. 69-70, p. 221-237, jan./dez. 2009.

DIREITO, Carlos Gustavo Vianna. Do controle disciplinar do juiz à luz da jurisprudência do Superior Tribunal de Justiça. Rio de Janeiro: Renovar, 2003.

DOBROWOLSKI, Sílvio. Processo administrativo disciplinar: direito de defesa e controle judicial. Revista de Informação Legislativa, Brasília, DF, v. 18, n. 72, p. 253-266, out./dez. 1981.

DROMI, Roberto. Derecho administrativo. 5. ed. Buenos Aires: Ediciones Ciudad Argentina, 1996. 
DRUZIANI, Yvelise de Cássia. O servidor público civil e a nova Administração Pública brasileira. Campinas: Copola Livros, 1996.

DUTRA, Pedro Paulo de Almeida. Servidores públicos não funcionários. Revista de Direito Público, São Paulo, v. 7, n. 31, p. 59-63, set./out. 1974.

ESCOBAR, Theo. Pessoal temporário no serviço público e seu regime jurídico em face da Constituição. Revista da Procuradoria Geral do Estado de São Paulo, São Paulo, n. 1, p. 139-145, 1971.

FAGUNDES, Miguel Seabra. O controle dos atos administrativos pelo Poder Judiciário. 5. ed. Rio de Janeiro: Forense, 1979.

FARIA, Anacleto de Oliveira. Os servidores públicos face às novas constituições. Revista de Direito Público, São Paulo, a. 1, n. 4, p. 145-153, abr./jun. 1968.

FARIAS, Márcia Albuquerque Sampaio. Sanções disciplinares aos servidores públicos: discricionariedade e controle judicial na aplicação. Rio de Janeiro: Letra Legal, 2004.

FERRAZ, Sérgio. Instrumento de defesa do administrado. Revista de Direito Administrativo, Rio de Janeiro, n. 165, p. 11-22, jul./set. 1986.

FERREIRA, Daniel. Sanções administrativas. São Paulo: Malheiros. 2001. . Teoria geral da infração administrativa. Belo Horizonte: Fórum, 2010.

FERREIRA, Luiz Pinto. Curso de direito constitucional. 5. ed. São Paulo: Saraiva, 1991.

FERREIRA, Sérgio de Andrea. A garantia da ampla defesa no direito administrativo processual disciplinar. Revista de Direito Público, São Paulo, a. 5, n. 19, p. 60-68, jan./mar. 1972.

FERREIRA FILHO, Manoel Gonçalves. Comentários à Constituição Brasileira de 1988. São Paulo: Saraiva, 1990, v. 1. . Curso de direito constitucional. 25. ed. São Paulo: Saraiva, 1999.

FIGUEIREDO, Lúcia Valle. Discricionariedade: poder ou dever. In: MELLO, Celso Antônio Bandeira de (Coord.). Curso de direito administrativo. São Paulo: Revista dos Tribunais, 1986. p. 120-135.

. Controle da Administração Pública. São Paulo: Revista dos Tribunais, 1991.

. Estado de Direito e devido processo legal. Revista do Tribunal Regional Federal $\overline{\text { da 3. }}{ }^{a}$ Região, São Paulo, n. 32, p. 15-27, out./dez. 1997.

FIGUEIREDO, Yuri Jordy N. A natureza jurídica da contratação de servidores temporários pela Administração Pública e a competência para julgamento. L\&C Revista de Administração Pública e Política, Brasília, DF, v. 12, n. 135, p. 39-40, set. 2009. 
FIORINI, Bartolomé A. La discrecionalidad en la administración pública. Buenos Aires: Alfa, 1948.

FORSTHOFF, Ernst. Traité de droit administratif allemand. Traduit de l'allemand par Michel Fromont. Bruxelles: Établissements Émile Bruylant, 1969.

FORTINI, Cristiana. Pessoal temporário: admissão e regime jurídico. In: CONGRESSO BRASILEIRO DE DIREITO ADMINISTRATIVO, 26., 2012, Vitória. O direito administrativo e a concretização de valores constitucionais. Vitória: Instituto Brasileiro de Direito Administrativo, 2012. 1 DVD.

FROTA, Hidemberg Alves da. Remoção ex officio, por alegada conduta ilícita, de servidor público federal temporário. Revista Bonijuris, Curitiba, a. 18, n. 512, p. 16-18, jul. 2006.

FURTADO, Lucas Rocha. Curso de direito administrativo. Belo Horizonte: Fórum, 2007.

GANDOLFO, Orlando Carlos. Extranumerário - Estabilidade. Revista de Direito Administrativo, Rio de Janeiro, n. 108, p. 455-461, abr./jun. 1972.

GARCÍA DE ENTERRÍA, Eduardo. Democracia, jueces y control de la Administración. 4. ed. Madrid: Civitas, 1998.

GARCÍA DE ENTERRÍA, Eduardo; FERNÁNDEZ, Tomás-Ramón. Curso de Derecho Administrativo. 7. ed. Madrid: Civitas, 1996, v. 1.

GARRIDO FALLA, Fernando. Tratado de derecho administrativo. Parte General. 12. ed. Madrid: Editorial Tecnos, 1994a, v. 1.

. Tratado de derecho administrativo. Parte General: conclusión. 12. ed. Madrid:

Editorial Tecnos, 1994b, v. 2.

GIANNINI, Massimo Severo. Derecho administrativo. Traducción Luis Ortega. Madrid: Ministerio para las Administraciones Públicas, 1991, v. 1.

GORDILLO, Agustín. La garantía de defensa como principio de eficacia en el procedimiento administrativo. Revista de Direito Público, São Paulo, a. 3, n. 10, p. 16-24, out./dez. 1969. 1995, t. 1.

. Tratado de Derecho Administrativo. 3. ed. Parte General. Buenos Aires: Macchi,

GRAU, Eros Roberto. UNICAMP-Universidade Estadual de Campinas - Professores universitários - Contrato por prazo determinado - Ausência de concurso público - Regime estatutário sistema previdenciário. Revista Trimestral de Direito Público, São Paulo, n. 39, p. 109-115, jul./set. 2002.

GRINOVER, Ada Pellegrini. O princípio da ampla defesa. Revista da Procuradoria Geral do Estado de São Paulo, São Paulo, n. 19, p. 9-20, dez. 1981/dez. 1982.

O processo em evolução. Rio de Janeiro: Forense Universitária, 1996. 
GROTTI, Dinorá Adelaide Musetti. O serviço público e a Constituição brasileira de 1988. São Paulo: Malheiros, 2003.

HARGER, Marcelo. Princípios constitucionais do processo administrativo. Rio de Janeiro: Forense, 2001.

LEITE, Luciano Ferreira. Discricionariedade administrativa e controle judicial. São Paulo: Revista dos Tribunais, 1981.

LIMA, J. B. de Menezes. Sindicância e verdade sabida: teoria e prática. São Paulo: Saraiva, 1989.

LINS, Adriane de Almeida; BOMFIM, Débora Vasti S. Processo administrativo disciplinar: manual. Belo horizonte: Fórum, 2007.

LUCON, Paulo Henrique dos Santos. Devido processo legal substancial. In: DIDIER JUNIOR, Fredie (Org.). Leituras complementares de processo civil. 5. ed. Salvador: Juspodivm, 2007. p. 19-32.

LUNA FILHO, Eury Pereira. Contratos de trabalho nulos na administração. Boletim de Direito Administrativo, São Paulo, v. 14, n. 6, p. 377-382, jun. 1998.

LUZ, Egberto Maia. Direito administrativo disciplinar. 3. ed. São Paulo: RT, 1994.

MADALENA, Pedro. O processo administrativo disciplinar sob o enfoque prático. Curitiba: Juruá, 1999.

MADEIRA, José Maria Pinheiro. Servidor público na atualidade. 8. ed. Rio de Janeiro: Elsevier, 2010.

MAGALHÃES, Gustavo Alexandre. O desrespeito ao princípio da valorização do trabalho humano por meio da contratação temporária de servidores públicos. Revista de Direito Administrativo, Rio de Janeiro, n. 239, p. 111-118, jan./mar. 2005.

. Contratação temporária por excepcional interesse público: aspectos polêmicos. 2 . ed. São Paulo: Atlas, 2012.

MATTOS, Mauro Roberto Gomes de. Lei $n .^{\circ} 8.112 / 90$ interpretada e comentada. Rio de Janeiro: América Jurídica, 2006.

2010.

. Tratado de direito administrativo disciplinar. 2. ed. Rio de Janeiro: Forense,

MAURER, Hartmut. Droit administratif allemand. Traduit par Michel Fromont. Paris: L.G.D.F., 1994.

Elementos de direito administrativo alemão. Tradução de Luís Afonso Heck.

Porto Alegre: Sergio Antonio Fabris, 2001. 
MAYER, Otto. Derecho administrativo alemán. Traducción directa del original francés por Horacio H. Heredia y Ernesto Krotoschin. Buenos Aires: Editorial Depalma, 1949, t. 1.

MELLO, Celso Antônio Bandeira de. Discricionariedade administrativa e controle judicial. Revista de Direito Público, São Paulo, v. 7, n. 32, p. 18-30, nov./dez. 1974.

. Discricionariedade: fundamentos, natureza e limites. Revista de Direito Público, São Paulo, v. 7, n. 33, p. 85-98, jan./mar. 1975.

Controle judicial dos atos administrativos. Revista de Direito Público, São Paulo, v. 16 , n. 65 , p. 27-38, jan./mar. 1983.

Elementos do direito administrativo. 3. ed. São Paulo: Malheiros, 1991.

Discricionariedade e controle jurisdicional. 2. ed. São Paulo: Malheiros, 2000.

MELLO, Marcos Bernardes de. Teoria do fato jurídico: plano da existência. 14. ed. São Paulo: Saraiva, 2007.

MELLO, Oswaldo Aranha Bandeira de. Princípios gerais de direito administrativo. 2. ed. Rio de Janeiro: Forense, 1979, v. 1.

MELLO, Rafael Munhoz de. Princípios constitucionais de direito administrativo sancionador: as sanções administrativas à luz da Constituição Federal de 1988. São Paulo: Malheiros, 2007.

MIKALOVSKI, Algacir; GARRETT, Waldick Alan de Almeida. Prática, processo e procedimentos administrativos. Curitiba: Juruá, 2003, v. 2.

MODESTO, Paulo. Notas para um debate sobre o princípio da eficiência. Boletim de Direito Administrativo, São Paulo, v. 16, n. 11, p. 830-837, nov. 2000.

MORAES, Alexandre de. Direito constitucional. São Paulo: Atlas, 1999.

MORAES, Germana de Oliveira. Controle jurisdicional da Administração Pública. São Paulo: Dialética, 1999.

MOREIRA, Egon Bockmann. Processo administrativo. São Paulo: Malheiros, 2000.

MOTTA, Carlos Pinto Coelho. Terceiro regime jurídico. Revista de Direito Administrativo, Rio de Janeiro, v. 147, p. 7-22, jan./mar. 1982.

. O novo servidor público: regime jurídico único. Belo Horizonte: Editora Lê, 1990. Servidores temporários: até quando? Boletim de Direito Administrativo, São

Paulo, v. 12, n. 8, p. 494-502, ago. 1996.

MOTTA, Fabrício. Concurso público e constituição. Belo Horizonte: Fórum, 2007. 
MOTTA, Ivan Martins. Estrito cumprimento de dever legal e exercício regular de direito. São Paulo: Juarez de Oliveira, 2000.

MOURA, Paulo Veiga e. Comentários aos Estatutos das Carreiras de Docente do Ensino Universitário e Politécnico. Coimbra: Coimbra Editora, 2009.

NOGUEIRA, Rubem Rodrigues. Aplicação do princípio da ampla defesa no procedimento administrativo disciplinar. Revista de Informação Legislativa, Brasília, DF, v. 14, n. 53, p. 237-244, jan./mar. 1977.

OLIVEIRA, Regis Fernandes de. Infrações e sanções administrativas. São Paulo: RT, 2005.

OSÓRIO, Fábio Medina. Direito administrativo sancionador. 3. ed. São Paulo: Revista dos Tribunais, 2009.

PAGLIARO, Antônio; COSTA JUNIOR, Paulo José. Dos crimes contra a Administração Pública. São Paulo: Malheiros, 1999.

PAZZAGLINI FILHO, Marino. Princípios constitucionais reguladores da Administração Pública: agentes públicos, discricionariedade administrativa, extensão da atuação do Ministério Público e do controle do Poder Judiciário. São Paulo: Atlas, 2000.

PEREIRA, Armando. Prática do processo administrativo. 2. ed. Rio de Janeiro: Fundação Getúlio Vargas, 1966.

PEREIRA, Flávio Henrique Unes. Sanções disciplinares: o alcance do controle jurisdicional. Belo Horizonte: Fórum, 2007.

PEREIRA JÚNIOR, Jessé Torres. O direito à defesa na Constituição de 1988: o processo administrativo e os acusados em geral. Rio de Janeiro: Renovar, 1991.

PIERCE JR., Richard J.; SHAPIRO, Sidney A.; VERKUIL, Paul R. Administrative law and process. 2. ed. New York: The Foundation Press, 1992.

PONDÉ, Lafayette. Considerações sobre o processo administrativo. Revista de Direito Administrativo, Rio de Janeiro, a. VII, n. 130, p. 1-11, out./dez. 1977.

PRADO, Leandro Cadenas. Servidores públicos federais. Niterói: Impetus, 2005.

PRATES, Marcelo Madureira. Sanção administrativa geral: anatomia e autonomia. Coimbra: Almedina, 2005.

QUEIROZ, Carlos Alberto Marchi de. O sobrestamento do processo administrativo disciplinar. São Paulo: IGLU, 1998.

RAMALHO, Maria do Rosário Palma. Tratado de direito do trabalho. Parte II. Coimbra: Almedina, 2012. 
RAMALHO, Maria do Rosário Palma; BRITO, Pedro Madeira. Legislação do trabalho no sector público. Coimbra: Almedina, 2011.

RANIERI, Nina Beatriz Stocco. A autonomia universitária e a contratação temporária de excepcional interesse público. Cadernos de Direito Constitucional e Ciência Política, São Paulo, v. 1, n. 3, p. 85-91, abr./jun. 1993.

RÁO, Vicente. Ato jurídico: noção, pressupostos, elementos essenciais e acidentais, o problema do conflito entre os elementos volitivos e a declaração. 4. ed. São Paulo: Revista dos Tribunais, 1997.

REIS, Antônio Carlos Palhares Moreira. Processo disciplinar. 2. ed. Brasília, DF: Consulex, 1999.

REZENDE, Adriana Menezes de. Do processo administrativo disciplinar e sindicância. Rio de Janeiro: Lumen Juris, 2000.

RIGOLIN, Ivan Barbosa. Servidor público - três questões: 1) FGTS; 2) estabilidade de celetistas concursados; 3) contratações temporárias. In: ARAÚJO, Edmir Netto de; TELLES, Antonio A. Queiroz (Org.). Direito administrativo na década de 90: estudos jurídicos em homenagem ao professor J. Cretella Junior. São Paulo: Revista dos Tribunais, 1997. p. 267-290. 2008 O servidor público nas reformas constitucionais. 3. ed. Belo Horizonte: Fórum,

RIVERO, Jean. Direito administrativo. Tradução de Rogério Ehrhardt Soares. Coimbra: Almedina, 1981.

ROMITA, Arion Sayão. Relação de emprego nas empresas estatais: empregado ou servidor público? Genesis: Revista de Direito do Trabalho, Curitiba, v. 5, n. 25, p. 7-14, jan. 1995.

ROZA, Cláudio. Processo administrativo disciplinar \& ampla defesa. Curitiba: Juruá, 2004.

SANTOS, Fernanda Marinela de Sousa. Servidores públicos. Niterói: Impetus, 2010.

SILVA, Antônio Álvares da. Os servidores públicos e o direito do trabalho. São Paulo: LTR, 1993.

SILVA, Carlos Medeiros. Pessoal temporário. Regime jurídico. Controle judicial. Revista de Direito Administrativo, Rio de Janeiro, v. 134, p. 227-234, out./dez. 1978.

SILVA, Edson Jacinto da. Sindicância e processo administrativo disciplinar: doutrina, jurisprudência e prática. São Paulo: LED, 1999.

SILVEIRA, Raquel Dias da. Profissionalização da função pública. Belo Horizonte: Fórum, 2009. 
SOARES, José de Ribamar Barreiros. O controle judicial do mérito administrativo. Brasília, DF: Brasília Jurídica, 1999.

SOARES, Rogério Guilherme Ehrhardt. Interesse público, legalidade e mérito. Coimbra: [s.n.], 1955.

SUNDFELD, Carlos Ari. A importância do procedimento administrativo. Revista de Direito Público, São Paulo, a. XX, n. 84, p. 64-74, out./dez. 1987.

TÁCITO, Caio. Poder disciplinar e direito de defesa. Revista de Direito Administrativo, Rio de Janeiro, v. 37, p. 345-352, jul./set. 1954.

TEIXEIRA, Mariana Rufino. Contrato de trabalho em funções públicas. Lisboa: Verlag Dashofer, 2009.

VELLOSO, Carlos Mário da S. Controle externo do Poder Judiciário e controle de qualidade do Judiciário e da magistratura: uma proposta. Revista de Direito Administrativo, Rio de Janeiro, n. 195, p. 9-23, jan./mar. 1994.

VIEIRA, Iva Carla; MONTEIRO, José Pinto; PINTO, Susana Costa. Gestão e organização de processos disciplinares dos trabalhadores em funções públicas. Porto: Vida Econômica, 2010.

VIGOUROUX, Christian. Déontologie des fonctions publiques. 2 éd. Paris: Dalloz, 2014.

VILHENA, Paulo Emílio Ribeiro de. Contrato de trabalho com o Estado. São Paulo: LTR, 1975.

VOGEL NETO, Gustavo Adolpho. Contratação de servidores temporários pela Administração Pública. Genesis: Revista de Direito do Trabalho, Curitiba, n. 43, p. 32-43, jul. 1996. 